О.В. Молчанова, Е.В. Пронина

\title{
АУДИТ ВНЕШНЕЭКОНОМИЧЕСКОЙ ДЕЯТЕЛЬНОСТИ
}

Учебное пособие

Астрахань, 2011 


\section{Составители :}

Молчанова О.В. - к.э.н., профессор, зав. кафедрой "Бухгалтерский учет, анализ хозяйственной деятельности и аудит".

Пронина Е.В. - к.э.н., доцент кафедры "Бухгалтерский учет, анализ хозяйственной деятельности и аудит".

Рецензент:

Гаджиев Н.Г. - д.э.н., профессор, зав. кафедрой "Экономического анализа" ФГОУ ВПО «Дагестанский государственный университет» 


\section{Оглавление}

Стр.

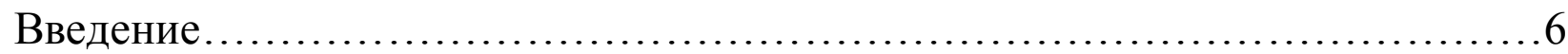

Глава 1. Понятие, виды, задачи и сущность внешнеэкономической

деятельности......................................................... 10

1.1. Понятие и сущность внешнеэкономической деятельности..............10

1.2. Виды, задачи и объекты внешнеэкономической деятельности..........18

1.3.Документальное оформление внешнеторговых контрактов и

валютных расчетов во внешнеэкономической деятельности............30

Контрольные вопросы.............................................53

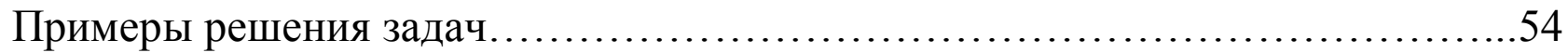

Задачи для самостоятельного решения.....................................55

Контрольные тесты.................................................56

Глава 2. Регулирование и контроль внешнеэкономической деятельности........61

2.1.Цели и методы государственного регулирования ВЭД ................61

2.2.Регулирование внешнеэкономической деятельности..................89

2.2.1. Международное регулирование ВЭД ..........................89

2.2.2. Таможенное регулирование ВЭД................................92

2.2.3. Валютное регулирование ВЭД............................... 138

2.3.Этапы и элементы контроля внешнеэкономической деятельности..... 143

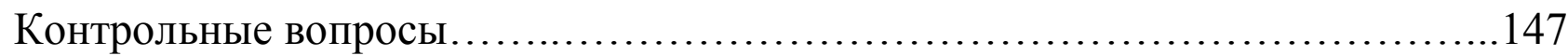

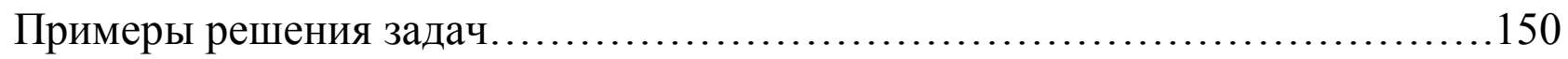

Задачи для самостоятельного решения.................................... 153

Контрольные тесты................................................... 156

Глава 3. Понятие, цели и задачи аудита внешнеэкономической деятельности...159

3.1.Понятие, цели, задачи и последовательность аудита внешнеэкономической деятельности............................. 159

3.2.Источники информации аудита внешнеэкономической деятельности.....170

3.3.Особенности и отличие аудита внешнеэкономической деятельности от других форм экономического контроля внешнеэкономической

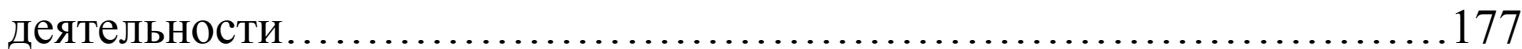


Контрольные вопросы..................................................181

Примеры решения задач............................................ 182

Задачи для самостоятельного решения................................. 182

Контрольные тесты...................................................183

Глава 4. Нормативно-правовое регулирование и организация аудита внешнеэкономической деятельности.............................. 184

4.1. Нормативно-правовое регулирование и организация аудита внешнеэкономической деятельности............................. 184

4.2. Направления аудиторских проверок внешнеэкономической деятельности.

4.3. Пользователи материалов аудиторских заключений при аудите внешнеэкономической деятельности........................192

4.4. Критерии аудита и особенности его информационной базы.............198

Контрольные вопросы................................................203

Примеры решения задач................................................203

Задачи для самостоятельного решения....................................205

Контрольные тесты.....................................................207

Глава 5. Основные этапы, техника и технология проведения аудиторской проверки внешнеэкономической деятельности....................208

5.1. Преддоговорные отношения между аудиторами и аудируемыми лицами........................................208

5.2. Порядок заключения договоров на оказание аудиторских услуг......224

5.3. Оценка применимости допущения непрерывности деятельности в

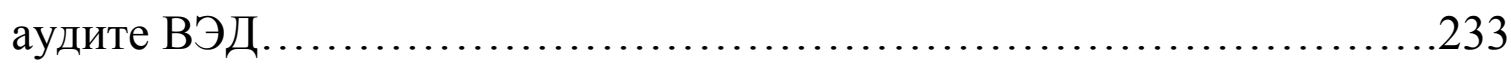

5.4. Планирование и программа аудита ВЭД.........................252

5.5. Сбор аудиторских доказательств..................................273

5.6. Заключительный этап аудиторской поверки ВЭД...................290

Контрольные вопросы..............................................2292

Примеры решения задач................................................295

Задачи для самостоятельного решения...................................2297 
Контрольные тесты........................................................297

Глава 6. Методика аудита внешнеэкономической деятельности...............300

6.1. Аудит имущества и обязательств, выраженных в иностранной валюте..............................................300

6.2. Методика аудита соблюдения организациями-экспортерами правил ведения бухгалтерского учета..............................312

6.3. Особенности аудиторских доказательств достоверности

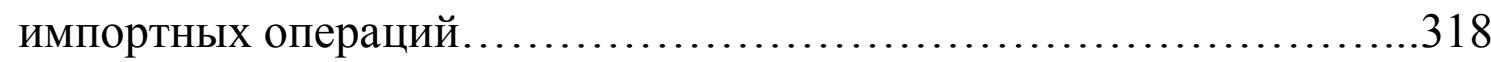

6.4. Основные направления аудита импортных операций.................322

6.5. Типичные ошибки, выявленные аудиторами в процессе аудита внешнеэкономической деятельности хозяйствующих субъектов..........330

Контрольные вопросы......................................................332

Примеры решения задач.................................................... 334

Задачи для самостоятельного решения...................................334

Контрольные тесты....................................................

Глава 7. Особенности аудита прочих операций по ВЭД........................341

7.1. Аудит сделок встречной торговли................................. 341

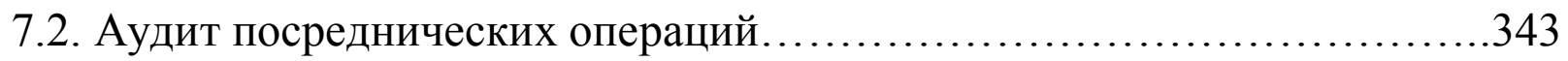

7.3. Аудит соответствия внешнеэкономических операций правовому, валютному и таможенному законодательству .........................344

7.4. Аудит оказания услуг по договорам между резидентами и нерезидентами..................................................349

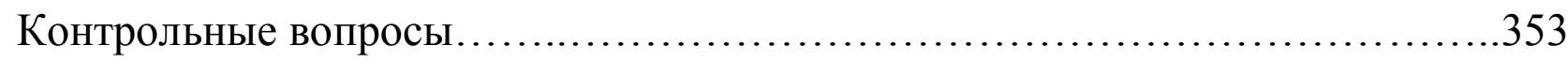

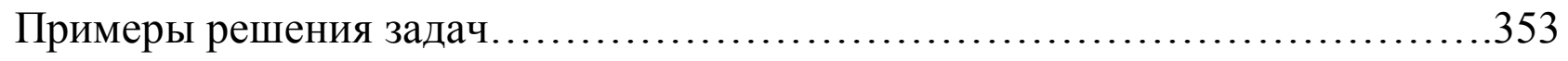

Задачи для самостоятельного решения....................................354

Контрольные тесты................................................... 357

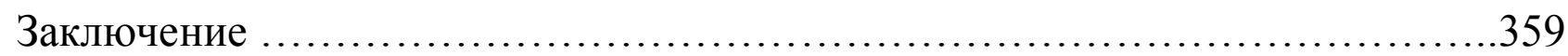

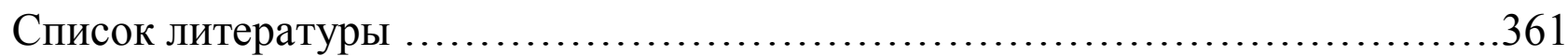

Приложения ........................................................... 364 


\section{Введение}

На протяжении многих лет в экономически развитых странах аудиторская деятельность является важной и неотъемлемой частью экономики, системой проверки и подтверждения достоверности бухгалтерской отчетности экономических субъектов. При этом выражение аудитором мнения о достоверности проверяемой отчетности предполагает соблюдение аудитором единых для всех аудиторов правил (стандартов) и выполнение обязательных аудиторских процедур.

Стремительное развитие рыночной экономики в России также способствует все большему развитию аудита как независимого контроля, обеспечивающего пользователей бухгалтерской отчетности экономических субъектов информацией о ее достоверности.

Хотелось бы отметить, что в России за сравнительно короткий период времени аудиторская деятельность прошла этап становления, и продолжает развиваться. При этом контроль и подтверждение достоверности информации, отражаемой в бухгалтерской и налоговой отчетности, проводимые независимыми аудиторами, позволяют заинтересованным пользователям принимать правильные управленческие решения, способствуя снижению предпринимательских рисков.

Одной из важнейших сфер деятельности российских предприятий на современном этапе является внешнеэкономическая.

В результате этого возникла объективная необходимость в изучении внешнеэкономической деятельности. Для наиболее эффективного еe осуществления необходимо обладать достаточными теоретическими и практическими знаниями в этой области. Кроме того, сложное законодательство, регулирующее внешнеэкономическую деятельность организаций, не всегда однозначно трактует отдельные хозяйственные ситуации, что также негативно сказывается на результативности внешнеторговых операций.

Особенности осуществления внешнеэкономической деятельности 
определяют требования к проведению ее аудита. При этом формирование мнения аудитора о достоверности бухгалтерской отчетности экономического субъекта должно основываться, в том числе, и на результатах аудита внешнеэкономической деятельности. Следует отметить, что, учитывая разнообразные риски, связанные с осуществлением внешнеэкономической деятельности, в достоверности данных о внешнеэкономической деятельности в бухгалтерской отчетности можно убедиться только по результатам ее аудита.

Целью данного учебного пособия «Аудит внешнеэкономической деятельности» является изложение теоретических положений аудита внешнеэкономической деятельности, порядка регулирования аудита внешнеэкономической деятельности в РФ, изучение статистических и аналитических приемов, применяемых в аудите внешнеэкономической деятельности, принципов проведения внешней и внутренней аудиторской проверки в организациях, занимающихся внешнеэкономической деятельностью.

Изучение учебного пособия обеспечивает ознакомление с теоретическими основами аудита внешнеэкономической деятельности и его ролью в развитии функции контроля; способствует получению системы знаний об аудите внешнеэкономической деятельности как о системе контроля за внешнеэкономической деятельностью предприятия, a также усвоению методологических основ организации аудиторской деятельности, технологических основ проведения аудиторских проверок и подготовки отчетности по результатам аудиторской проверки внешнеэкономической деятельности.

Основными задачами изучения курса «Аудит внешнеэкономической деятельности», которые были рассмотрены авторами данного учебного пособия, являются:

1. Усвоение теоретических основ техники и технологии проведения аудиторских проверок внешнеэкономической деятельности, порядка регулирования аудиторской деятельности в РФ. 
2. Получение системы знаний о методике организации аудиторской деятельности для осуществления контроля за деятельностью предприятия, осуществляющего внешнеэкономическую деятельность.

3. Умение решать задачи сбора, регистрации и обобщения фактов финансово-хозяйственной деятельности организации с целью формирования полной и достоверной информации о внешнеэкономической деятельности предприятия и его имущественном положении.

4. Умение осуществлять контроль за законностью и целесообразностью хозяйственных операций, наличием и движением имущества и обязательств, использованием материальных, трудовых и финансовых ресурсов, предотвращением отрицательных результатов хозяйственной деятельности организаций, осуществляющих внешнеэкономическую деятельность.

5. Умение находить ошибки в организации и методике ведения бухгалтерского учета внешнеэкономической деятельности.

6. Умение использовать систему знаний о методике организации аудиторской деятельности для полной и достоверной информации об организации и ведении бухгалтерского учета в хозяйствующем субъекте, осуществляющем внешнеэкономическую деятельность.

В результате ознакомления с данным пособием читатели могут усвоить теоретические положения аудита внешнеэкономической деятельности, действующий порядок регулирования аудиторской деятельности в РФ; принципы проведения аудиторской проверки внешнеэкономической деятельности; стандарты аудита, определяющие организацию и методику осуществления аудиторской проверки в организациях, занимающихся внешнеэкономической деятельностью. Кроме этого, они смогут решать задачи сбора, регистрации и обобщения фактов финансово-хозяйственной деятельности организации с целью формирования полной и достоверной информации о ее деятельности и имущественном положении; осуществлять 
контроль за законностью и целесообразностью хозяйственных операций, наличием и движением имущества и обязательств, использованием материальных, трудовых и финансовых ресурсов, предотвращением отрицательных результатов хозяйственной деятельности организаций; находить ошибки в организации и методике ведения бухгалтерского учета; использовать систему знаний о методике организации аудиторской деятельности как на внешнем, так и на внутреннем уровне, для полной и достоверной информации об организации и ведении бухгалтерского учета в хозяйствующем субъекте. 


\section{Глава 1. Понятие, виды, задачи и сущность внешнеэкономической}

деятельности

\section{1. Понятие и сущность внешнеэкономической деятельности}

Внешнеэкономическая деятельность - существенная составляющая, важнейшее направление рыночной экономики. В процессе исторического развития России внешнеэкономическая деятельность оказывала влияние на решение экономических проблем на различных уровнях: народного хозяйства в целом, отдельных регионов, объединений, предприятий. Термин «внешнеэкономическая деятельность» (ВЭД) стал широко применяться в нашей стране в последнюю четверть XX в. Традиционная внешняя торговля значительно расширилась и усложнилась, появились другие виды и формы внешнеэкономического сотрудничества: достаточно самостоятельными видами внешнеэкономических связей стали технико-экономическое и научнотехническое сотрудничество. Последнее может трактоваться как составная часть научно-производственного сотрудничества, учитывая, что во внешнеэкономические связи активно вовлекались многие производственные отрасли. Развивались специализация и кооперирование производства с зарубежными партнерами, а также прямые связи между отечественными и иностранными предприятиями, совместное предпринимательство, инвестиционное сотрудничество. Отечественные организации стали предоставлять новые виды услуг иностранным заказчикам, возрастали транзитные перевозки иностранных грузов через территорию нашей страны.

Многообразное содержание ВЭД нашло отражение в структуре, функциях и практической деятельности соответствующих органов государственного управления, специализированных внешнеэкономических организаций, отраслевых производственных объединений и предприятий.

Внешнеэкономическая деятельность относится к одной из сфер международного бизнеса, основанного на базе производства продукции (выполнения работ и предоставления услуг), предназначенной для зарубежных 
рынков. В российской практике это понятие стало активно использоваться с конца 80-х годов XX века в связи с осуществлением внешнеэкономической реформы (1986-1987гг.), результатом которой явилась децентрализация государственной внешней торговли и переход от системы межправительственных внешнеэкономических связей $\quad$ (ВЭС) к самостоятельному осуществлению ВЭД на уровне предприятий производителей экспортной продукции. Таким образом, в российской действительности сложилось два понятия: «внешнеэкономические связи» и «внешнеэкономическая деятельность».

Внешнеэкономические связи (ВЭС) - это одна из форм межгосударственных отношений в области научно-, военно-технического, производственного и торгово-экономического сотрудничества и валютнофинансового взаимодействия.

Как экономическая категория ВЭС представляет собой систему экономических отношений при движении ресурсов всех видов между государствами и экономическими субъектами разных государств. Эти отношения охватывают не только производственную деятельность, но и торговую, инвестиционную и финансовую.

Формами ВЭС являются:

- внешняя торговля;

- совместное (международное) предпринимательство и оказание услуг;

- сотрудничество, содействие.

Разница между понятиями «внешнеэкономические связи» и «внешнеэкономическая деятельность» заключается в том, что внешнеэкономические связи относятся к уровню макроэкономического (межгосударственного) регулирования, а внешнеэкономическая деятельность к микроуровню, т.е. к уровню фирм и предприятий.

В связи с переходом от государственной монополии к либерализации ВЭД в конце 1980-х — начале 1990-х годов сфера ВЭД стала доступной для 
многих союзных, республиканских и местных организаций, предприятий различных форм собственности.

В 1990-е годы участниками ВЭД стали сотни тысяч юридических лиц и миллионы физических лиц, ВЭД приобрела массовый характер.

Термин «внешнеэкономическая деятельность» впервые был законодательно закреплен в Конституции СССР 1977 г., где указывалось, что внешняя торговля и другие виды внешнеэкономической деятельности осуществляются на основе государственной монополии. Однако само понятие ВЭД тогда не было раскрыто.

Содержание понятия ВЭД было расшифровано в Федеральном законе «Об экспортном контроле» 1999 г.: «внешнеэкономическая деятельность внешнеторговая, инвестиционная и иная деятельность, включая производственную кооперацию, в области международного обмена товарами, информацией, работами, услугами, результатами интеллектуальной деятельности, в том числе исключительными правами на них (интеллектуальная собственность)». В данном определении выделены основные виды и объекты ВЭД.

Внешнеэкономическая деятельность относится к рыночной сфере отношений, базируется на критериях предпринимательской деятельности, структурной связи с производственными процессами и отличается правовой и экономической автономностью, а также юридической независимостью от отраслевой ведомственной опеки.

Внешнеэкономическая деятельность в отличие от ВЭС осуществляется на уровне предприятий, частично или полностью (100\%) обеспечивающих производство экспортной продукции (работ и услуг) и реализацию ее на внешнем рынке. Такие промышленные предприятия, компании, научнопроизводственные объединения и организации принято именовать как экспортоориентированные.

Внешнеэкономическая деятельность представляет собой комплекс 
системообразующих факторов, положенных в основу единого технологического процесса производства и реализации экспортной продукции в соответствии с избранной предприятием внешнеэкономической стратегией, a также формами и методами работы на зарубежных рынках.

В основе ВЭД предприятий лежит полная степень самостоятельности в разработке экспортной стратегии, в выборе экспортного продукта, его товарной номенклатуры и состава ассортиментных позиций, исходя из производственнотехнологических возможностей, а также внешнего рынка, иностранного партнера, базисных и финансово-экономических условий внешнеторговых сделок, в определении экспортной цены и стоимости контракта, сроков поставки продукции и способов транспортировки.

Для большинства российских предприятий ВЭД является органической частью их производственно-коммерческой деятельности в системе взаимодействия как со смежными предприятиями-партнерами на внутреннем рынке, так и с зарубежными на внешнем. Необходимыми условиями для осуществления ВЭД предприятиями являются фиксация в их уставе права на осуществление ВЭД, наличие соответствующих лицензий и разрешений на ведение отдельных видов деятельности или проведение отдельных валютных операций. ВЭД реализуется через совокупность производственнохозяйственных, организационно-экономических и оперативно-коммерческих функций, ориентированных на внешний рынок. Выход на внешний рынок требует рыночной ориентации не только в системе хозяйствования, но и в принципах управления производством и сбытом, научно-технической и финансовой деятельностью предприятий, опирающихся на маркетинговые оценки и исследования, исходя из достоверной информационной базы.

Исходным принципом ВЭД предприятий служит коммерческий расчет на основе хозяйственной и финансовой самостоятельности и самоокупаемости с учетом наличия собственных материально-технических и валютно-финансовых возможностей для обеспечения производства экспортной продукции.

Особое значение в осуществлении ВЭД имеет принцип валютной 
самоокупаемости и самофинансирования, которые обеспечиваются за счет валютных поступлений от экспортных продаж на внешнем рынке. Сосредоточенные на текущем валютном счете, они образуют валютный фонд предприятия.

Участник ВЭД, как любой хозяйствующий субъект на российском рынке, может открыть в своем уполномоченном банке (УБ) валютный счет в любой иностранной свободно конвертируемой валюте (СКВ) или в нескольких СКВ, так называемые мультивалютные или конверсионные счета, в том числе за рубежом, при условии наличия лицензии Центрального банка РФ (ЦБ РФ). Открытие валютных счетов в нескольких видах СКВ позволяет экспортоориентированным предприятиям избежать процессов конверсии одного типа валюты в другую, а значит, и дополнительных валютнофинансовых издержек и рисков, которые сопровождают процесс обменных валютных операций. Курсовые разницы, связанные с пересчетом валют (в случае конверсии), также относятся на валютный счет предприятия.

Валютные средства могут храниться и на депозитных счетах ЦБ РФ, что требует заключения соответствующего договора между банком и предприятием. По вкладам на депозитных счетах начисляются проценты в счет увеличения размеров валютных средств, a, кроме того, появляются преимущества на пользование банковским кредитом и инновационным финансированием. Размер комиссии (начисления процента) либо принимается на основе договора между уполномоченным банком и его клиентом, либо базируется на действующих процентных ставках ЦБ РФ на межбанковском рынке на момент зачисления валютных средств на валютный счет предприятия.

Открытие валютного счета потенциальным участником ВЭД предполагает оформление одновременно двух его разновидностей: транзитного и текущего, которые ведутся параллельно. Валютная выручка, поступающая от экспорта товаров (работ и услуг), зачисляется сначала на транзитный счет предприятия-экспортера, а затем перечисляется на текущий валютный счет.

Начисления и выплата процентов в отношении валютных средств 
предприятий, хранящихся на текущем валютном счете, производятся банками только по тем видам СКВ, по которым они имеют прибыль от их размещения на международном валютном рынке. Что касается валютных средств на транзитном валютном счете, то начисление процентов по ним не производится.

Остающаяся в распоряжении предприятий-экспортеров валютная выручка расходуется в целях развития экспортного производства, его технической реконструкции и модернизации, проведения научно-исследовательских и конструкторских работ. Она может также направляться на оплату импортных закупок машин, оборудования и материалов, необходимых для нужд технического перевооружения и совершенствования экспортных технологий.

Ответственность за результаты ВЭД полностью несут сами предприятия не только в части экспортных поставок и выполнения условий внешнеторговых сделок, но и импортных закупок, необходимых для развития процессов экспортного и импортозамещающего производства.

Внешнеэкономическая деятельность предприятий состоит из многочисленных элементов, сосредоточенных в составе группы функций производственно-хозяйственных (первая группа), организационно-экономических (вторая группа) и оперативно-коммерческих (третья группа), которые направлены на реализацию избранной экспортной стратегии и достижение эффективности внешнеторговых сделок.

В состав этой первой группы внешнеэкономических функций входят разработка экспортной стратегии предприятия и выбор формы ВЭД, установление межотраслевых внутрихозяйственных связей с партнерами, обеспечение производства экспортной продукции. Это достигается в процессе комплексного изучения внешних рынков, результаты которого экспортеры закладывают в основу текущих и долгосрочных программ своей деятельности. При выходе на рынки промышленно-развитых стран российские экспортерыпроизводители попадают в условия жесткой международной конкуренции. Этот факт заставляет до начала экспортной деятельности производить оценку 
собственных ресурсов, требующую анализа качества продукции и производственных возможностей, системы организации внешнеторговой деятельности (ВТД), привлечения капиталовложений и технологий в производство экспортной продукции и финансовых возможностей предприятия.

Прогнозируются динамика внутрипроизводственных ресурсов, внешние условия деятельности предприятий-экспортеров, намечается степень их деловой активности.

Далее обосновывается выбор товарных позиций и определяется ассортиментная структура в соответствии с кодом товарной номенклатуры ВЭД, производится оценка конкурентоспособности товара.

Дальнейшее продвижение экспортной продукции на внешний рынок обеспечивается в рамках осуществления внешнеторговой деятельности, как самим предприятием-экспортером, так и организацией-посредником на основе двух других внешнеэкономических функций.

Вторая группа внешнеэкономических функций предприятия-экспортера (организационно-экономические) нацелена на поиск иностранного партнера и выбор зарубежного рынка, форм и методов работы на нем, изучение комплекса обязательных процедур в составе технологического процесса выхода на внешний рынок и обстоятельств присутствия на рынке в стране своего зарубежного партнера, на планирование внешнеторговой операции и организацию внешнеторговой рекламы.

Выбор форм и методов работы на внешних рынках осуществляется в рамках избранной экспортной стратегии предприятия с предпочтением выбора наиболее эффективного вида ВЭД, организационных форм в системе международной торговли и утвердившихся традиций в зависимости от специфического характера ТН ВЭД и предмета сделки.

Технологический процесс выхода на внешний рынок, входящий в состав организационно-экономических функций, - это комплекс строго последовательных подготовительных операций и процедур, необходимых для 
реализации экспортной продукции иностранному партнеру и продиктованных требованиями системы государственной регламентации.

Он включает определенную последовательность действий предприятияэкспортера и прохождения необходимых организационных процедур внутри страны до момента заключения и непосредственной реализации внешнеторговой сделки:

- ознакомление с механизмом государственного регулирования внешнеторговой деятельности в России через законодательные акты и нормативно-техническую документацию в сфере ВЭД;

- выбор уполномоченного банка и открытие валютного счета;

- изучение системы и полномочий федеральных структур, занимающихся рассмотрением и оформлением заявительно-разрешительных документов, в рамках прохождения процедур нетарифных ограничений ВТД (лицензий, квот, паспорта экспортной сделки);

- маркетинговые исследования и оценку конъюнктуры внешнего рынка;

- поиск необходимой информации для расчета экспортной цены и подготовки конкурентного листа;

- поиск иностранного партнера и проведение переговоров;

- оформление квот и лицензий;

- подготовку пакета товаросопроводительных документов для предстоящего таможенного оформления;

- подготовку проекта контракта и согласование его коммерческих и валютно-финансовых условий.

Третья группа функций в составе ВЭД предприятия - оперативнокоммерческие, связанные с подготовкой, а затем и исполнением внешнеторговой сделки и всех сопутствующих ей процессов, включая выбор и согласование экономических, базисных и валютно-финансовых условий внешнеторгового контракта, а также последующий контроль за исполнением расчетно-платежных обязательств со стороны иностранного партнера. 


\section{2. Виды, задачи и объекты внешнеэкономической деятельности}

Экспортная стратегия предприятия реализуется через конкретные виды ВЭД и известные мировой практике формы международной торговли, выбор которых во многом определяет цели присутствия и характер работы на внешнем рынке экспортеров-производителей.

Различают следующие виды ВЭД:

- внешнеторговая деятельность;

- международное инвестиционное сотрудничество;

- производственная кооперация;

- валютные и финансово-кредитные операции.

Понятие «внешнеторговая деятельность» было первоначально сформулировано в Федеральном законе «О государственном регулировании внешнеторговой деятельности» 1995 г., а затем скорректировано в Законе «Об основах государственного регулирования внешнеторговой деятельности» 2003 г. В новом законе внешнеторговая деятельность (ВТД) определена как деятельность по осуществлению сделок в области внешней торговли товарами, услугами, информацией и интеллектуальной собственностью. Словосочетание «осуществление сделок в области внешней торговли» прямо указывает на коммерческий характер ВТД, вместе с тем ВТД и вся ВЭД не ограничивается коммерческими рамками, вмещая в себя многие стороны общеэкономической и международной деятельности страны.

В основе процессов ВТД лежит косвенный метод исполнения внешнеторговых операций на базе традиционных международных коммерческих сделок купли-продажи, т.е. при помощи внешнеторговых посредников и передачи им полномочий по продаже и доставке продукции иностранному покупателю на условиях договора комиссии или агентского соглашения. Следовательно, в отличие от ВЭД внешнеторговая деятельность не имеет под собой производственной основы. Формами ВТД являются: экспорт, импорт, бартерные сделки, компенсационные сделки. 
В российской практике ВЭД большинства экспортоориентированных предприятий обеспечивается преимущественно посредством ВТД. Такую форму реализации экспортной стратегии используют в основном небольшие предприятия-производители $\mathrm{c}$ ограниченными производственными и финансовыми возможностями, которые не в состоянии выполнить весь комплекс внешнеэкономических функций.

В рамках крупных предприятий - производителей экспортной продукции, обладающих достаточным опытом работы на международном рынке, ВТД сконцентрирована в составе функциональной деятельности специально созданных внешнеторговых фирм (ВТФ) в структуре самого предприятия.

ВТД сопровождается большим объемом работ по обеспечению подготовительных этапов выхода на зарубежный рынок и заключению внешнеторговых сделок. В их числе - маркетинговые исследования внешнего рынка, проведение конъюнктурно-экономических прогнозных оценок и расчетов по обеспечению эффективности сделок, проработка условий контракта, поиск иностранного партнера. Кроме того, ВТД связана со значительным объемом сопутствующих ей операций, способствующих продвижению экспортной продукции от продавца к иностранному покупателю. К ним относятся различного рода посреднические операции (транспортные, складские, экспедиторские, брокерские, консалтинговые, банковские, консигнационные), страховые, расчетно-финансовые и валютные операции, процедуры таможенного оформления (декларирование, подтверждение таможенной стоимости, уплата таможенных платежей), квотирования и лицензирования и др. Весь комплекс подготовительных работ требует поиска необходимой информационной базы, ее изучения и проработки, особенно в отношении конъюнктурных параметров зарубежных товарных рынков и выявления обстоятельств предстоящей работы на них, связанных с национальными системами регламентирования ввоза иностранной продукции.

Международное инвестищионное сотрудничество как один из видов 
ВЭД предполагает взаимодействие отечественных предприятий с иностранными партнерами на основе взаимно выгодного объединения усилий финансового, научно- и производственно-технического характера. Целями такого сотрудничества в сфере ВЭД являются привлечение новых технологий и расширение производственной базы для развития процессов выпуска конкурентоспособной экспортной продукци, соответствующей международным критериям, систематического обновления товарной структуры и совершенствования качественных параметров в целях облегчения процессов доступа на зарубежные рынки и увеличения объемов реализации.

Формами международного инвестиционного сотрудничества являются: прямые зарубежные (иностранные) инвестиции, портфельные инвестиции, кредитные соглашения, международный финансовый лизинг, совместное производство в рамках совместного предприятия.

Производственная кооперация в составе ВЭД предприятий и фирм представляет одну из форм сотрудничества между иностранными партнерами в различных, но конструктивно связанных между собой процессах технологического разделения труда. Сам технологический процесс разделения труда означает распределение его участников в цепи создания и реализации продукции по основным его фазам - от изучения потребностей на внутренних и внешних рынках до доведения ее до конечных потребителей.

Производственная кооперация с иностранным партнером характерна для однородных сфер производства и обращения в направлении научнотехнического, инвестиционного и сервисного развития, например, в обрабатывающей промышленности.

В международной практике под производственным кооперированием принято понимать совместную деятельность, при которой обеспечивается соблюдение ряда необходимых условий:

1)обязательное присутствие в качестве непосредственных субъектов производственной кооперации промышленных компаний и предприятий разных стран; 
2)распределение между партнерами производственно-технических заданий в рамках согласованной программы;

3)закрепление за каждым из них производственной специализации, исходя из основных целей кооперационных соглашений;

4)осуществление между партнерами взаимных или односторонних поставок товаров с реализацией производственных программ в рамках кооперации;

5)закрепление в договорных соглашениях главных объектов кооперации- готовой продукции, ее компонентов и разновидностей, а также соответствующей технологии;

6)долгосрочность и стабильность производственно-экономических отношений между партнерами;

7)координация хозяйственной деятельности иностранных партнеров в согласованной области деятельности, избранной в качестве главной составляющей такого сотрудничества.

При производственном кооперировании собственность кооперантов не обособляется, а сотрудничество обеспечивается на возмездной основе и строится по принципу прямых связей между производителями однородной продукции.

Прямые производственные и научно-технические связи предприятий, объединений и организаций разных стран в современных условиях являются одним из главных средств осуществления специализации и производственной кооперации, обмена передовым производственным и научно-техническим опытом, освоения новой техники и технологий, создания образцов машин и оборудования. Они способствуют решению задач по дальнейшему развитию экспортного производства на основе использования возможностей международной кооперации, прежде всего, по новейшим и принципиально новым видам продукции и технологий, модернизации производства и экономии ресурсов, увеличения выпуска продукции, соответствующей по техническому уровню и качеству мировым критериям. 
В рамках прямых производственных связей решаются задачи не только производственной и научно-технической кооперации, но и создания совместных производств и предприятий, согласованности номенклатуры и объемов экспортно-импортных поставок продукции и оказания услуг в рамках кооперации. Внешнеторговые отношения при этом осуществляются на принципах взаимовыгодности и равноправия.

Производственная кооперация в сфере ВЭД в России в большей степени получила распространение в рамках предпринимательской деятельности в регионах приграничной и прибрежной торговли.

Валютные и финансово-кредитные операщии в качестве вида ВЭД предприятий и фирм следует рассматривать, в первую очередь, как содействующие, сопровождающие любую внешнеторговую сделку в виде финансовых обязательств, связанных с обеспечением платежа за поставленную продукцию через конкретные формы расчета, а также валютных операций, совершаемых в целях страхования рисков во избежание курсовых потерь.

Однако как валютные, так и финансово-кредитные операции можно рассматривать в качестве самостоятельных специфических видов ВЭД в непроизводственной сфере, например, в банковско-финансовой, обслуживающей внутренний валютный рынок и внешнеторговые платежи в системе международных расчетов, в области страхового дела и т.п.

Кроме рассмотренных видов ВЭД, необходимо учитывать и особые режимы ВТД, включая приграничную и прибрежную торговлю, а также внешнеэкономические операции, осуществляемые в особых экономических зонах (ОЭ3), которые затрагивают интересы целого ряда регионов и субъектов РФ. Например, объем приграничной торговли с соседними провинциями КНР (Хэйлунцзян, Ляонин, Цзилинь, Внутренняя Монголия, Синцзян-Уйгурский автономный район) в середине нынешнего десятилетия превысил 5 млрд долл. в год (более четверти всего товарооборота РФ с КНР).

Согласно Федеральному закону «Об особых экономических зонах в Российской Федерации» от 22 июля 2005 г. ОЭЗ создаются в целях развития 
обрабатывающих отраслей экономики, высокотехнологичных отраслей, производства новых видов продукции, транспортной инфраструктуры, а также туризма и санаторно-курортной сферы. Предусмотрено создание ОЭЗ трех типов: 1) промышленно-производственные, 2) технико-внедренческие и 3 ) туристско-рекреационные. Со 2-й половины 1990-х годов функционируют две ОЭЗ в Калининградской и Магаданской областях. В 2005 г. были созданы шесть ОЭЗ - в Зеленограде, Дубне, Санкт-Петербурге, Томске, Липецкой области и Татарстане. Продукция, производимая на территории ОЭЗ, может реализовываться как на внутреннем, так и на внешнем рынке.

Глобальная цель ВЭД предприятия - максимизация массы и нормы прибыли на основе использования преимуществ международного разделения труда - реализуется за счет решения следующих задач:

- расширения сбыта выпускаемой продукции путем освоения новых рынков за рубежом, расширения круга покупателей товара по причине его новизны или предпочтительности по ценам или качеству;

- минимизации издержек производства и удельных затрат на единицу продукции при оптимизации размеров производства, превышающих емкость внутреннего рынка;

- снижения издержек реализации товаров путем выбора правильной стратегии сбыта (создания собственной инфраструктуры зарубежных продаж или использования специализированного посредника с его торгово-сбытовой сетью, применения комбинированных схем);

- обеспечения потребностей в закупках сырья, комплектующих изделий, новейших технологий, оборудования и ноу-хау, привлечения инжиниринговых услуг для производственных нужд, исходя из их уникальности, более высокого качества и низких цен относительно внутреннего рынка;

- продления жизненного цикла продукции путем ее реализации на новых рынках, характеризующихся более низким уровнем потребностей и платежеспособного спроса;

- обеспечения более полной загрузки производственных мощностей и 
стабилизации сбыта продукции в результате кооперации;

- минимизации затрат на обновление основного капитала путем использования возможностей международного лизинга;

- повышения качества продукции посредством применения новых технологий, материалов, дизайнерских решений и других средств;

- повышения эффективности вложения капитала, прежде всего в предпринимательской форме, для экономии издержек производства, оптимизации производственно-сбытовой сети (приближения к источникам сырья, дешевой рабочей силы и рынкам сбыта), диверсификации деятельности как средства обеспечения финансовой устойчивости, а также повышения прибыли на фоне снижения налоговых отчислений.

Объектами ВЭД являются товары, услуги, технологии, капиталы, которые под управляющим воздействием субъектов вовлекаются в процессы межстранового перемещения. Поскольку наиболее распространенным видом ВЭД является внешнеторговая деятельность, остановимся на характеристике ее объектов.

В законе «Об основах государственного регулирования внешнеторговой деятельности» 2003 г. выделено четыре группы объектов (предметов) ВТД: 1) товары, 2) услуги, 3) информация и 4) интеллектуальная собственность; конкретизировано содержание внешней торговли по каждому из перечисленных объектов. Охарактеризуем соответствующие положения закона.

1. Внешняя торговля товарами - импорт и (или) экспорт товаров. Товаром как предметом ВТД считается движимое имущество, отнесенные к недвижимому имуществу суда — воздушные, морские, внутреннего и смешанного (река - море) плавания и космические объекты, а также электрическая энергия и другие виды энергии. При этом в качестве товара не рассматриваются транспортные средства, используемые по договорам международных перевозок.

Таким образом, к товарам относятся овеществленные объекты внешнеторгового обмена, так называемые видимые товары. Как в российской 
внешней торговле, так и в международной торговле в целом, обращается множество товаров, являющихся продуктами материального производства.

Российские участники ВЭД должны во всех внешнеторговых документах указывать наименование каждой товарной позиции строго в соответствии с действующей Товарной номенклатурой внешнеэкономической деятельности (ТН ВЭД), которая была разработана на основе международной Гармонизированной системы описания и кодирования товаров (ГС). ГС стала внедряться в 1988 г. с целью унификации товарной классификации в международной торговле, таможенном деле, транспортных операциях и статистике, и теперь применяется в большинстве стран мира.

В ТН ВЭД вошло 10666 позиций с 10-значными кодами. Во внешнеторговой таможенной статистике РФ в последние годы выделяются следующие крупные товарные группы:

- продовольственные товары и сельскохозяйственное сырье;

- минеральные продукты (в том числе топливно-энергетические товары, руды и концентраты, фосфаты);

- продукция химической промышленности (в том числе удобрения минеральные, медикаменты, химические средства защиты растений) и каучук;

• кожевенное сырье, пушнина и изделия из них;

• древесина и целлюлозно-бумажные изделия;

- текстиль, текстильные изделия (в том числе ткани, одежда) и обувь;

- драгоценные камни, драгоценные металлы и изделия из них;

- металлы (черные и цветные) и изделия из них;

- машины, оборудование и транспортные средства (в том числе автомобили легковые и грузовые);

- другие товары (в том числе мебель).

Поставки внешнеторговых товаров, зафиксированные по дате их перемещения через границу, составляют так называемый видимый экспорт и импорт. Их совокупный объем характеризует внешнеторговый оборот страны и 
торговый баланс за определенный период времени (год, квартал, месяц).

2. Внешняя торговля услугами - оказание услуг (в том числе выполнение разнообразных работ), включающее производство, распределение, маркетинг и доставку услуг (работ). Оказание услуг осуществляется следующими способами:

1) с территории РФ на территорию иностранного государства;

2) с территории иностранного государства на территорию РФ;

3) на территории РФ иностранному заказчику услуг;

4) на территории иностранного государства российскому заказчику услуг;

5) российским исполнителем услуг, не имеющим коммерческого присутствия на территории иностранного государства, путем присутствия его или уполномоченных действовать от его имени лиц на территории иностранного государства;

6) иностранным исполнителем услуг, не имеющим коммерческого присутствия на территории РФ, путем присутствия его или уполномоченных действовать от его имени иностранных лиц на территории РФ;

7) российским исполнителем услуг путем коммерческого присутствия на территории иностранного государства;

8) иностранным исполнителем услуг путем коммерческого присутствия на территории РФ.

Такая развернутая трактовка способов предоставления услуг сходна с содержащейся в Генеральном соглашении по торговле услугами (ГАТС) ВТО. Согласно ГАТС в международную торговлю услугами входит не только трансграничный обмен ими, но также поставка и получение услуг иностранными юридическими и физическими лицами на территории какой-либо страны.

Таким образом, услуги могут оказываться путем их поставки с территории одной страны на территорию другой страны (трансграничное перемещение услуг), когда поставщик и потребитель услуги находятся по разные стороны таможенной границы, или путем предоставления услуг на 
территории одной страны, когда поставщик услуги перемещается из своей страны на территорию страны потребителя либо иностранный потребитель услуги перемещается на территорию страны поставщика (перемещение из страны в страну не самих услуг, а их производителей или потребителей).

Соответственно в российский экспорт услуг входит потребление услуг иностранными лицами не только за рубежом, но и в нашей стране, а импортом услуг считается получение иностранных услуг как на территории России, так и в зарубежных странах.

Применяемая в ГАТС классификация услуг по их содержанию (объекту) включает 161 вид услуг, сгруппированных в 12 разделов:

1. Деловые услуги.

2. Услуги связи.

3. Строительные и инжиниринговые услуги.

4. Дистрибьюторские услуги.

5. Общеобразовательные услуги.

6. Услуги по защите окружающей среды.

7. Финансовые услуги, включая страхование.

8. Услуги по охране здоровья и социальные услуги.

9. Туризм и путешествия.

10. Услуги в области организации досуга, культуры и спорта.

11. Транспортные услуги.

12. Прочие услуги.

Учитывая, что в российском законодательстве к услугам отнесено также выполнение работ, ряд видов работ могут являться предметом внешнеторговых сделок: научно-исследовательские и опытно-конструкторские (НИОКР), изыскательские, геологоразведочные, проектные, конструкторские, строительно-монтажные, пусконаладочные, технологические, ремонтные, реставрационные и др. Многие виды работ осуществляются на подрядных условиях, в том числе на условиях генерального подряда. В последнем случае генеральный подрядчик обеспечивает сдачу построенного объекта 
иностранному заказчику «под ключ» с возможным последующим доведением его до проектной мощности и организацией гарантийного и послегарантийного обслуживания. Выполнение различных работ сопряжено с применением как умственного, так и физического труда.

Значительная часть услуг вместе с другими объектами ВТД (кроме товаров) составляет «невидимый» экспорт и импорт, который не входит в торговый баланс страны, но отражается на ее платежном балансе. При поставках товаров, выполнении работ, передаче результатов интеллектуальной деятельности нередко предоставляются так называемые сопутствующие услуги.

3. Внешняя торговля информащуией может осуществляться двояким образом: информация выступает либо в качестве самостоятельного объекта ВТД, либо как неотъемлемое дополнение к другим объектам ВТД. Как самостоятельный объект ВТД информация может предоставляться по коммерческим, производственным, научно-техническим и иным вопросам. Достоверную и оперативную информацию специального характера следует расценивать в качестве одного из наиболее дорогостоящих объектов внешней торговли.

Согласно закону внешняя торговля информацией отождествляется с другими объектами ВТД в следующих случаях:

1) если информация является составной частью реализуемых товаров, это считается внешней торговлей товарами;

2) если передача информации осуществляется как передача прав на объекты интеллектуальной собственности, это относится к внешней торговле интеллектуальной собственностью;

3) в других случаях расценивается как внешняя торговля услугами.

Информация, необходимая для использования поставляемого товара, обычно называется сопутствующей информацией.

4. Внешняя торговля интеллектуальной собственностью - передача исключительных прав на объекты интеллектуальной собственности или предоставление права на использование объектов интеллектуальной собственности 
российским лицом иностранному лицу либо иностранным лицом российскому лицу.

В понятие «интеллектуальная собственность» заложено исключительное право собственника распоряжаться результатами своей интеллектуальной (творческой) деятельности. Объекты торговли результатами этой деятельности иначе называются товарами «духовного производства». К ним относятся научно-технические изобретения и открытия, новые технологии, ноу-хау, программные продукты, произведения литературы и искусства, реализуемые в виде лицензий, патентов, авторских прав.

Купля-продажа объектов интеллектуальной собственности может осуществляться на условиях простого (неисключительного) соглашения, т.е. без предоставления покупателю исключительного права на использование данного объекта, или с исключительным правом покупателя использовать такой объект на договорной территории, а также с преимущественным правом покупателя на такое приобретение (право «первой руки»), что не детализировано в законе.

В отечественной практике внешняя торговля результатами интеллектуальной деятельности велась по двум основным направлениям:

1) возмездная передача результатов научно-технических исследований и изобретений в виде лицензий, ноу-хау, проведение научно-исследовательских и опытно-конструкторских работ (НИОКР) на заказной и совместной основе, научно-технических экспертиз, консультаций, других видов научнотехнических работ;

2) экспорт и импорт авторских прав на произведения литературы и искусства.

К внешнеторговым сделкам данной группы относится также возмездный обмен с иностранными партнерами концертными, театральными, теле- и радиопрограммами, проведение на коммерческой основе международных кинофестивалей, других творческих мероприятий с участием иностранных деятелей культуры, прокат в зарубежных странах кино-, теле- и видеофильмов, 
совместное с иностранными продюсерами производство фильмов, платные публичные выступления отдельных лиц, чтение лекций в зарубежных странах, интервью (в том числе «эксклюзивные») российских лиц иностранным СМИ и иностранных лиц российским СМИ и т.д.

\section{3.Документальное оформление внешнеторговых контрактов и валютных расчетов во внешнеэкономической деятельности}

Внешнеэкономическая деятельность реально осуществляется посредством внешнеэкономических операций, которые представляют собой комплекс действий по подготовке, заключению и исполнению сделок какого-либо вида или формы ВЭД.

Так как основу ВЭД составляет внешняя торговля, то наибольший удельный вес во внешнеэкономических операциях занимают внешнеторговые операцчии.

Внешнеторговая операщия - это комплекс действий, включающих подготовку, заключение и исполнение внешнеторговой сделки.

Внешнеторговые операции весьма разнообразны по содержанию. Среди них обычно выделяются основные $u$ обеспечивающие внешнеторговые операцฺии.

Содержанием основных операциий является купля-продажа и поставка тех или иных товаров, оказание разнообразных услуг, выполнение работ, в том числе на условиях подряда, обмен другими объектами ВТД на возмездных условиях. В группу основных операций входят экспортные, импортные и товарообменные (компенсационные), в том числе операции по экспорту и импорту специфических товаров таких, как лицензии, авторские права, иные объекты интеллектуальной собственности, по оказанию различных видов услуг, выполнению тех или иных работ. К этой же группе операций относятся арендные (лизинговые), давальческие, торгово-посреднические операции.

Операции, обеспечивающие нормальный внешнеторговый обмен (иногда их называют вспомогательными), обычно тесно привязаны к основным 
операциям, хотя формально осуществляются относительно самостоятельно, причем в них могут участвовать и иные субъекты ВТД.

В эту группу входят отдельные операции по изготовлению, упаковке, хранению, контролю качества, сертификации экспортных и импортных товаров, их сдаче-приемке, составлению необходимой документации, таможенному оформлению, транспортно-экспедиторскому обслуживанию, страхованию, расчетам, кредитованию, рекламе внешнеторговых товаров, патентованию изобретений и промышленных образцов, регистрации товарных знаков и знаков обслуживания, оказанию информационно-консультационных и иных услуг, связанных с поставкой товаров, ведению претензионных и арбитражных дел.

В соответствии с международной коммерческой практикой на одну основную операцию приходится более десяти вспомогательных.

В составе внешнеторговых операций обеспечивается подготовка и заключение разнообразных сделок, исходя из особенностей предмета обмена и его условий.

Внешнеторговая сделка - это действие, направленное на установление, изменение или прекращение гражданско-правовых отношений сторонами, которые находятся в разных странах, и имеющее вид экспортно-импортных, товарообменных, разовых, долгосрочных и других сделок.

Внешнеторговая сделка оформляется контрактом.

Внешнеторговый контракт - это договор, соглашение между двумя или несколькими участниками, находящимися в различных странах, по поставке установленного количества товара или оказанию услуг в соответствии с согласованными условиями.

Основополагающей для составления условий договоров международной купли-продажи является «Конвенция Организации объединенных наций о договорах международной купли-продажи товаров», которая была подписана в Вене в 1980 г. Главной идеей разработчиков данной Конвенции было примирение двух противостоящих тенденций: национальных систем 
регулирования купли-продажи и универсального характера современного международного товарообмена.

Венская конвенция 1980 г. является документом, который подписали свыше 70 государств, в том числе Россия, Белоруссия, Украина, Эстония, Грузия, Литва и т.д.

Конвенция состоит из четырех частей:

Часть 1 «Сфера применения и общие положения» содержит указания на отношения, которые регламентируются Конвенцией, а также фиксирует некоторые важные условия. В частности, указывается на то, что договор купли-продажи может быть заключен либо в письменной, либо в устной форме.

Часть 2 «Заключение договора» касается вопросов, которые вытекают из заключения договора путем направления одной стороной предложения (оферты) заключить договор и согласия (акцепта) на заключение договора другой стороны.

Часть 3 «Купля-продажа товаров» непосредственно содержит ряд положений, касающихся обязанностей продавца и покупателя, перехода риска повреждения и потери товара, обеспечения его сохранности, освобождения сторон от ответственности.

Часть 4 содержит некоторые заключительные положения относительно порядка присоединения к ней других стран.

Россия присоединилась к этой Конвенции в 1991 году, при этом было оговорено условие, согласно которому в торговле с российскими участниками контракты в устной форме не применяются. В том случае, если не удается договориться с торговым партнером о том, право какой стороны будет применяться при составлении и трактовании условий контракта, можно включить в контракт ссылку на Венскую конвенцию при условии, если его страна также является участницей этой Конвенции. Положения Венской конвенции во многом созвучны с положениями ст. 454 -491 Гражданского кодекса РФ.

Подготовка и проведение экспортной и импортной сделки осуществляется 
в несколько этапов: поиск партнеров, переговорный процесс, заключение и исполнение (расторжение) контрактов. Каждый из этих этапов имеет свое содержание и организационное оформление. Разница между подготовкой экспортной и импортной сделки заключается в содержании первого этапа - в поиске партнеров, так как в первом случае необходимо найти покупателя, а во втором - продавца товара.

Чтобы найти покупателя, экспортер может: подготовить предложение (оферту) одному или нескольким потенциальным покупателям; направить покупателю предложение в ответ на его запрос; принять участие в торгах путем предоставления тендера; организовать и принять участие в выставках и ярмарках; отослать проформу контракта уже известному покупателю и т.д.

Оферта - письменное предложение продавца, направленное возможному покупателю, о продаже партии товара на определенных продавцом условиях. Здесь содержатся все основные условия предстоящей сделки, которые затем войдут в текст контракта (наименование товара, его количество и качество, цена и условия поставки, срок поставки и вид упаковки). Оферта может быть твердой, когда она посылается оферентом одному возможному покупателю с указанием срока, в течение которого продавец является связанным своим предложением и не может сделать аналогичное предложение другому покупателю. Согласие покупателя со всеми условиями оферты в виде письменного подтверждения называется акцептом. Свободная оферта делается нескольким потенциальным покупателям на одну и ту же партию товара. Она не устанавливает срок для ответа и поэтому не связывает оферента своим предложением. Согласие покупателя с условиями, изложенными в такой оферте, подтверждается твердой контрофертой.

$$
\text { Способы установления контактов с }
$$
продавцом-экспортером в рамках подготовки импортной сделки следующие: направить потенциальному или уже известному продавцу запрос; объявить торги с приглашением фирм-производителей интересующих покупателей товаров; направить экспортеру безоговорочный акцепт его предложения. 
Наиболее распространенной формой первого этапа подготовки импортной сделки является размещение заказа - коммерческого документа, в котором покупатель подробно указывает все необходимые условия для изготовления или подготовки заказываемого товара, а также все существенные элементы, необходимые для заключения внешнеторговой сделки.

Подписанию контракта всегда предшествуют переговоры, где согласовываются все основные условия. Переговоры могут вестись путем переписки, по телефону и в ходе личных встреч.

К основным способам заключения сделки в международной практике относятся: подписание контракта, акцепт покупателем твердой оферты, акцепт продавцом контроферты покупателя, подтверждение продавцом заказа, сделанного покупателем.

Так, например, стадия установления контакта с партнером может быть оформлена с применением следующих документов:

Таблица 1

\section{Стадия установления контакта с партнером}

\begin{tabular}{|c|c|}
\hline Предложение поставщика & $\begin{array}{l}\text { Оферта твердая или свободная, деловые } \\
\text { письма, проект контракта, факс/телекс }- \\
\text { сообщение }\end{array}$ \\
\hline Ответ покупателя на размещение заказа & Акцепт, контроферта, встречный запрос \\
\hline $\begin{array}{c}\text { Обращение покупателя о конкурентном } \\
\text { предложении }\end{array}$ & Запросы, заказы, инициативные письма \\
\hline Вызов на торги продавца & Приглашение, уведомление \\
\hline Ответ продавца на запрос & Оферта, проформа (проект) контракта \\
\hline Подтверждение продавцом контроферты & Акцепт, проект контракта \\
\hline Согласие на участие в торгах & Тендер \\
\hline Проверка платежеспособности & Справки, запросы, банковские или \\
Покупателя & коммерческие отсылки \\
\hline
\end{tabular}

В процессе подготовки, переговоров, заключения и исполнения контрактов появляется ряд документов, которые объединяются в группу внешнеторговых документов.

Соответственно оформление заказа покупателем можно представить следующим образом: 


\section{Оформление заказа покупателем}

\begin{tabular}{|c|c|}
\hline $\begin{array}{c}\text { Принятие и подтверждение заказа } \\
\text { продавцом }\end{array}$ & $\begin{array}{c}\text { Безусловный акцепт предложения } \\
\text { покупателя, проект контракта }\end{array}$ \\
\hline Оформление сделки & Акцепт твердой оферты продавца, \\
& встречная оферта \\
\hline Указание о поставке & График поставки, закупочный ордер \\
\hline
\end{tabular}

Внешнеторговые сделки могут заключаться на международных выставках и ярмарках. Ярмарка - коммерческое предприятие, основной целью которого является заключение торговых сделок по выставляемым товарам. Выставка - публичная демонстрация достижений тех или иных отраслей материальной или духовной сферы жизни общества, основная цель которой - обмен идеями, теориями, знаниями при одновременном проведении коммерческой работы. Выставки и ярмарки, как правило, проводятся регулярно и являются как международными, так и национальными мероприятиями. Различают также специализированные, оптовые и постоянно действующие экспозиции.

Контракт - это важнейший внешнеторговый коммерческий документ, оформляющий сделки купли-продажи товаров, услуг и других объектов ВТД. Проработка условий контракта, согласование их с иностранным контрагентом и надлежащее оформление контракта относятся к ключевым этапам внешнеторговой операции.

Условия контракта должны соответствовать императивным нормам отечественного и международного права, сложившейся торговой практике и обычаям, действующим в странах контрагентов.

В зависимости от вида сделки и ее конкретных условий внешнеторговые контракты отличаются большим разнообразием. Так, например, имеется ряд особенностей в контрактах купли-продажи различных сырьевых товаров и машинотехнических изделий. Специфичными являются контракты на строительство или модернизацию промышленных предприятий и других объектов, поставку запчастей, взаимные поставки кооперированной продукции, поставку и переработку давальческого сырья, предоставление различных видов 
услуг, выполнение подрядных работ, подготовку производственнотехнических, административно-управленческих специалистов и т.д.

Контракт представляет собой совокупность взаимосвязанных условий.

Условие внешнеторгового контракта — это пункт, параграф или статья договора, фиксирующая отдельные обязанности сторон по сделке.

Структура внешнеторгового контракта, как правило, включает в себя следующие статьи:

- преамбулу;

- предмет контракта (наименование товара);

- количество товара;

- качество товара;

- цену и общую стоимость;

- базисные условия поставки;

- сроки поставки;

- упаковку и маркировку;

- условия платежа;

- транспортные условия (порядок отгрузки);

- страхование;

- сдачу-приемку товара;

- гарантии;

- рекламации;

- штрафные санкции;

- форс-мажор;

- арбитраж;

- прочие условия.

Структура контракта, т.е. набор условий и их последовательность определяется характером сделки, видом товара, отношениями сторон и т.д. Например, при купле-продаже машин и оборудования в контракт включаются такие статьи, как «технические условия», «техническая документация», «гарантийный период», «послегарантийное обслуживание» и т.П. При 
купле-продаже товаров, требующих получения экспортных (импортных) лицензий, в контракт включается статья «лицензии».

Необходимо отметить, что специального законодательного акта, регулирующего вопрос об обязательных условиях внешнеторгового контракта, в российском законодательстве нет. Содержащийся в Гражданском кодексе РФ перечень отдельных условий договора купли-продажи (глава 30, ч.1) нельзя считать достаточным, поскольку внешнеторговый контракт - документ особый, специфический, и поэтому требующий отдельного (специального) законодательного регулирования.

При заключении внешнеторгового контракта российским участникам ВЭД рекомендовано уполномоченными банками и таможенными органами руководствоваться разработанным в МВЭС России и введенным в действие в 1996 г. документом под названием «Рекомендации по минимальным требованиям к обязательным реквизитам и форме внешнеторговых контрактов» от 29 февраля 1996 года, которые приведены в приложении 1. При всей своей неполноте и несовершенстве, Рекомендации в настоящее время являются единственным нормативным документом, более или менее регулирующим вопрос об обязательных условиях внешнеторгового контракта.

Базисные условия поставки и их роль при заключении внешнеторговых контрактов. ИНКОТЕРМС-2000

При определении цены сделки, таможенной стоимости важным моментом является зависимость цены от условий поставки товаров. Для правильной интерпретации условий конкретных видов сделок Международной торговой палатой были введены правила интерпретации коммерческих терминов «ИНКОТЕРМС», которые содержат свод коммерческих терминов, наиболее часто встречающихся в международной торговой практике. При использовании ИНКОТЕРМС сводятся к минимуму неопределенности и потери, обусловленные различным толкованием торговых терминов в разных странах мира.

С момента создания Инкотермс в 1936 году они корректировались в 1953, 
1967, 1976, 1980, 1990 и 2000 годах. Последняя редакция учитывает развитие зон, свободных от таможенных пошлин, внедрение в практику торговли электронной связи и изменения в практике перевозок грузов.

Следует отметить, что Инкотермс является нормативным документом в том случае, если на них сделана прямая ссылка в контракте, и при этом в контракте не предусмотрено иного, чем в тексте Инкотермс.

Выбор коммерческих условий поставки зависит от продавца и покупателя, что оговаривается в контракте. В зависимости от коммерческих условий поставки, цена в счет-фактуре (инвойсе), выставленная продавцом покупателю, будет различной. Так, например, один и тот же товар будет иметь одну цену в месте его покупки, другую (более высокую) - в порту прибытия, поскольку по мере продвижения товара от производства к потребителю стоимость будет увеличиваться из-за дополнительных расходов на перевозку, страхование и т. д. В счет-фактуру (инвойс) продавец включает только те затраты, которые он несет в соответствии с коммерческим условием поставки товара. На основании этих затрат формируется фактурная стоимость декларируемой партии товаров, выраженная в валюте контракта.

Таким образом, условия поставки отличаются по структуре уплаченной цены, т. е. по составу расходов, включенных в цену. Так, при использовании цены EXW или FOB с точки зрения требований к структуре таможенной стоимости необходимо произвести дополнительные начисления к цене сделки, так как в них не вошли расходы на перевозку и страхование груза. Наиболее удобной для таможенной оценки является цена DAF — граница Российской Федерации. Однако при этом следует иметь ввиду, что при использовании цены DAF может пониматься также граница страны - экспортера, либо третьей стороны, через которую груз проходит транзитом.

\section{Группа Е Отправление}

EXW Франко завод (...название места)

\section{Группа F Основная перевозка не оплачена}

FCA Франко перевозчик (... название места назначения) 
FAS Франко вдоль борта судна (... название порта отгрузки)

FOB Франко борт (... название порта отгрузки)

\section{Группа С Основная перевозка оплачена}

CFR Стоимость и фрахт (... название порта назначения)

CIF Стоимость, страхование и фрахт (... название порта назначения)

СРТ Фрахт/перевозка оплачены до (... название места назначения)

CIP Фрахт/перевозка и страхование оплачены до (... название места назначения)

\section{Группа D Прибытие}

DAF Поставка до границы (... название места поставки)

DES Поставка с судна (... название порта назначения)

DEQ Поставка с пристани (с оплатой пошлины) (... название порта назначения)

DDU Поставка без оплаты пошлины (... название места назначения)

DDP Доставлено с оплатой пошлины (... название места назначения)

Применение терминов ИНКОТЕРМС - 2000 в практике коммерческой работы при включении их в договор купли-продажи характеризуется следующими особенностями:

1. С правовой точки зрения этот документ имеет факультативный, рекомендательный характер. В связи с этим стороны, которые используют в своей работе его торговые условия, должны делать ссылку на данный документ в договоре купли-продажи.

2. Термины ИНКОТЕРМС - 2000 по многим вопросам носят общий характер. Поэтому в соответствующих разделах договора купли-продажи сторонам необходимо уточнять и конкретизировать детали распределения обязанностей между продавцом и покупателем.

3. Стороны договора купли-продажи имеют право формулировать и применять любые условия поставок, в том числе могут использоваться ранние версии ИНКОТЕРМС. В договоре этот момент должен быть четко оговорен. 
4. В связи с широким признанием ИНКОТЕРМС во всех странах мира при заполнении таможенных документов в графе «Условия поставки», как правило, требуется указание базисных условий поставки в соответствии с терминами, принятыми Международной торговой палатой.

ИНКОТЕРМС - 2000 регламентирует ряд важных моментов, связанных с поставкой товара, а именно:

- фиксирует распределение издержек по транспортировке товара между продавцом и покупателем. Эти расходы достаточно разнообразны и составляют иногда 40-50\% цены товара. Они могут включать: расходы по подготовке товара к отгрузке; оплату погрузки и перевозки товара; оплату страхования груза при перевозке; расходы по хранению товара в пути; оплату таможенных пошлин, налогов и сборов при переходе таможенной границы и др.;

- определяет момент перехода с продавца на покупателя риска утраты и повреждения товара. Это означает, что неблагоприятные последствия изменений качества и количества товара несет та сторона, на которой лежит ответственность за груз на конкретном участке пути.

Всего ИНКОТЕРМС - 2000 содержит 13 базисных условий поставок, которые дают различные сочетания обязанностей, расходов и степени риска продавца и покупателя по международному договору купли-продажи. Для удобства применения и понимания все условия разделены на четыре группы, начиная с того момента, когда продавец предоставляет в распоряжение покупателя готовый товар непосредственно на своем складе. Эти группы (англ. E, F, C, D) расположены в определенной последовательности, отражающей увеличение ответственности продавца и его расходов, что влияет на повышение уровня контрактной цены.

Важной особенностью рассматриваемых условий является их классификация в зависимости от способов транспортировки товара и видов транспорта, а также конкретные рекомендации Международной торговой палаты по их использованию. Рассмотрим применение ИНКОТЕРМС по 
отношению к видам перевозки. Термины базисных условий поставки такие, как: EXW, FCA, CPT, CIP применяются при любых видах транспорта; DDU, DDP - при смешанных перевозках; DAF - при перевозках автомобильным и железнодорожным транспортом; FAS, FOB, CFR, CIF, DES, DEQ - при перевозках морским (внутренним) водным транспортом.

При использовании партнерами в договорах торговых условий следует точно указывать, по какой редакции рассматривается их толкование, а также точно определять географическую точку распределения расходов и рисков. Например, «СIF Новороссийск» ИНКОТЕРМС - 2000 означает, что продавец должен доставить груз на морском судне за свой счет в порт Новороссийск, застраховать его и нести риск потерь и повреждения груза только до порта погрузки. При этом толкование термина CIF производится в соответствии с ИНКОТЕРМС - 2000.

Документы в составе внешнеторговых сделок можно разделить на три основные группы: товаросопроводительные, транспортные и расчетные. Охарактеризуем каждую из перечисленных групп документов.

Товаросопроводительные документы подтверждают все элемента подготовки внешнеторговой сделки и включают выписку коммерческого счета предварительного порядка и оформление сертификатов, удостоверяющих соответствие техническим стандартам и качеству, а также вес груза, характер упаковки, страну происхождения товара. Часть этих документов требуется для формирования пакета комбинированных товарных и транспортных документов.

Одним из таких товарных документов при частичных поставках выступает предварительный счет, на основе которого в дальнейшем после процедуры приемки всего объема поставленного товара или поставки всей партии продавец оформляет на имя покупателя счет-фактуру для окончательного расчета между партнерами. Она удостоверяет фактическую поставку товара и его стоимость и может быть использована в качестве накладной, сопровождающей груз. По требованию таможенных органов многих 
стран счет-фактура выписывается на бланках установленной формы и выступает подтверждением таможенной стоимости импортируемого товара, т.е. базой для исчисления таможенных платежей - пошлины и таможенных сборов.

Счет-проформа — предварительный или «фиктивный» счет, который выписывается до момента отправки товара и направляется покупателю. Выставляется при частичных отгрузках, при консигнации. В нем указывается цена товара, стоимость упаковки и величина транспортных расходов. Счетпроформа может также выписываться с целью уведомления грузополучателя о произведенной отгрузке. В этом случае покупатель может использовать счетпроформу для доказательства совершения покупки при необходимости обращения в уполномоченный банк для получения кредита или оформления импортной лицензии, а также лицензии для покупки валюты. Но при этом счетпроформа не может служить требованием об уплате долга.

Разновидностью комплексного товаросопроводительного документа, объединяющего реквизиты счета и товарной спецификации, является cчеmспецицфикация. Он содержит перечень всех товарных и ассортиментных позиций товаров, входящих в состав одной партии, с указанием цены за единицу продукции, места и количества каждого товара и общую стоимость всей партии отгруженного товара. Счет-спецификация сопровождает поставки разнородного ассортимента, а также оборудования. Обычно согласовывается контрагентами и составляет часть контракта. Одновременно может служить частью пакета расчетных документов.

Для сопровождения каждого товарного места — ящика, рулона, кипы, мешка - оформляется упаковочный лист, в реквизитах которого перечисляются все виды, сорта, ассортимент упакованной продукции с обозначением веса.

К числу гарантийных документов относится сертификат продукции, подтверждающий покупателю степень соответствия товара установленным 
международным нормам и стандартам, техническим условиям и требованиям эксплуатации.

Сертификат качества является наиболее распространенным товаросопроводительным документом, удостоверяющим качественные характеристики и технические параметры поставляемой продукции, предусмотренные условиями контракта. Данный документ оформляется чаще всего экспортером-производителем в нескольких экземплярах, один из которых сопровождает груз, а другие входят в состав пакета документов, необходимых для предъявления к оплате.

Сертификат о происхождении товара оформляется в целях подтверждения достоверности страны - производителя импортируемой продукции, где она была произведена полностью или подвергнута в большей степени технологической обработке или сборке. Этот документ требует представления при таможенном оформлении в стране импортера в режиме установленных преференций для отдельных групп стран по исчислению размера ввозных пошлин.

Статьями 34 - 36 ТК РФ предусмотрены несколько форм документов, подтверждающих страну происхождения товаров. Такими документами являются:

- декларация о происхождении товара;

- сертификат о происхождении товара.

Декларация о происхождении товара составляется в произвольной форме. Причем Кодекс позволяет в качестве такой декларации использовать коммерческие или иные документы, имеющие отношение к перемещаемым через таможенную границу товарам и содержащие заявление изготовителя (продавца или экспортера) товаров о стране их происхождения.

Сертификат о происхождении товара предоставляется только в случаях, определяемых Правительством РФ. Существуют несколько форм сертификатов. Сертификат происхождения товаров формы "А" предоставляется в отношении товаров, ввозимых из стран-пользователей системой преференций (льгот) РФ 
(стран дальнего зарубежья), и сертификат формы "СТ-1" - в отношении товаров, происходящих из стран СНГ.

Сертификат о происхождении товара должен однозначно свидетельствовать о том, что указанный товар происходит из соответствующей страны, и должен содержать следующие необходимые сведения о товаре, на который он выдан:

- наименование и адрес экспортера и импортера;

- наименование (описание) товара;

- средства транспортировки и маршрут следования;

- количество мест, характер упаковки, маркировку и нумерацию;

- вес брутто и нетто;

- номер счет фактуры (инвойса).

Сертификат должен быть заверен компетентным национальным органом страны-экспортера.

Сертификат о происхождении товара представляется вместе с таможенной декларацией и другими документами при таможенном оформлении. При утрате сертификата принимается его официально заверенный дубликат.

Вместе с тем, не всегда требуется подтверждать страну происхождения товаров. Например, в соответствии с ТК РФ не требуется предоставление документа, подтверждающего страну происхождения товаров:

- в случаях заявления ввозимых в РФ товаров к таможенному режиму международного таможенного транзита или временного ввоза (с полным освобождением временно ввозимых товаров от уплаты таможенных платежей), при отсутствии признаков, указывающих на страну, товары которой запрещены к ввозу в РФ или транзиту через территорию РФ;

- если общая таможенная стоимость перемещаемых через таможенную границу товаров (отправленных одновременно, одним отправителем, одним способом и в адрес одного получателя) менее 20000 рублей;

- товары перемещаются через таможенную границу физическими лицами 
не для предпринимательской деятельности;

- в иных случаях, предусмотренных международными договорами РФ или законодательством РФ (например, при перемещении товаров дипломатическими, консульскими и иными официальными представительствами иностранных государств, международными организациями, персоналом этих представительств и организаций).

Также не требуется документального подтверждения страны происхождения товаров, если предоставление тарифных преференций не предусмотрено международными договорами РФ или законодательством РФ.

В случаях, когда законодательством предусмотрено предоставление тарифных преференций, но документы, подтверждающие страну происхождения товаров отсутствуют, таможенные пошлины взимаются по ставкам, применяемым к товарам, происходящим из стран, торговополитические отношения с которыми предусматривают режим РНБ (наиболее благоприятствуемой нации (базовые ставки)).

Консульский счет (фактура) предъявляется вместе с экспортируемым товаром таможенным органам при его оформлении, если такое требование существует в стране импортера. Такой документ оформляется экспортером на специальном бланке, заверяется консулом страны импортера, подтверждая цену товара и стоимость всей партии после уплаты консульского сбора. Консульский счет также выступает как документ-поручительство, в котором подтверждается страна происхождения товара.

Извещуение о готовности товара является уведомлением о предстоящей отгрузке в адрес получателя без указания цены и стоимости, которое высылается покупателю.

К составу этой группы документов можно причислить комбинированнылй товаросопроводительный документ, сочетающий признаки одновременно нескольких видов документов, подтверждающие количественную и качественную характеристику поставляемых товаров на основе таких из них, как сертификат качества, упаковочный лист, отгрузочная спецификация, 
транспортная накладная, наконец, контракт и заказ. Его оформление значительно упрощает учет и обработку, а также сокращает количество документов, повышая степень контроля по подтверждению исполненной операции.

Следующая группа коммерческих документов относится в большей степени к разряду товарораспорядительных и сопровождает процесс поставки, транспортировки, и, кроме того, является основанием для подтверждения таможенной стоимости товара, права транзитного провоза через территорию сопредельных государств и выступает неотъемлемой частью расчетных операций в составе документарных аккредитивов и документарного инкассо, а также банковского перевода. В числе важнейших из них - инвойс и коносамент.

Инвойс (консульская фактура) представляет собой пакет документов, который оформляется экспортером на специальном типовом бланке и служит основанием для расчетной операции. В его состав наряду с контрактом и другими документами входит счет-фактура, где содержится детальный перечень отгруженных покупателю товаров и полная информация о количестве, качестве и цене товара, о нумерации и маркировке грузовых мест, о способе доставки груза покупателю. Инвойс в отдельных ситуациях может служить также сертификатом о происхождении товара.

В инвойсе помимо этого должны указываться все дополнительные издержки, если только товар не поставляется на условиях «фрахт оплачен» и «свободно от расходов по упаковке», которые включают стоимость упаковки и транспортировки, акциз и таможенные пошлины, расходы по складированию и страхованию.

Кроме того, в инвойсе проставляется номер контракта, величина скидки и способ ее предоставления, номер заказа и товарной накладной, дата отгрузки, а также фиксируются условия и форма платежа. Оригинал инвойса отсылается покупателю одновременно с отгрузкой товара или сразу же после нее, один экземпляр копии поступает в бухгалтерию для ведения учета, другой — в 
отдел сбыта для информации о способе упаковки.

Продавец, регистрируя копию высланного инвойса в книге продаж, дебетует таким образом счет покупателя, фиксируя сумму платежа в приходнорасходной книге, в которой ведутся кассовые счета.

Покупатель после проверки полученного счета регистрирует инвойс в своей книге покупок и, в свою очередь, кредитует продавца по его счету. Аббревиатура «E. \& O. E.», используемая на бланке инвойса, напоминает о том, что ошибки и пропуски не допускаются.

Во внешнеторговых перевозках важнейшим юридическим документом, удостоверяющим наличие договора перевозки морским или речным транспортом и конкретизирующим его условия, считается коносамент. Он относится также к типу ценных бумаг, поскольку обладает теми же свойствами передачи прав и равносилен передаче груза, т.е. получения права владения им.

Коносамент - это документ, выдаваемый перевозчиком, удостоверяющий принятие груза к перевозке с обязательством доставить его в порт назначения и выдать его законному держателю. Коносамент является договором морской перевозки в линейном судоходстве, выступает в роли расписки перевозчика в приемке груза и является товарораспределительным документом.

Различают следующие видьл коносамента: бортовой, коносамент для погрузки на борт судна, чистый, с оговоркой, оборотный, именной, ордерный, на предъявителя, линейный пароходный, чартерный, сквозной.

Охарактеризуем некоторые виды коносамента. По именному коносаменту груз получает лицо, на чье имя этот документ выписан. Ордерный коносамент выдается "приказу отправителя", "приказу получателя", его передача возможна по передаточной надписи того и другого. Предъявляемый коносамент передается простым вручением. Коносамент обычно составляется в нескольких экземплярах, о количестве которых делается отметка на каждом из них. После выдачи груза по одному остальные теряют силу.

В зависимости от выдачи коносамента на погруженный на судно груз или 
сданный на склад для отгрузки коносаменты бывают бортовые и коносаменты на груз, принятый к перевозке.

Коносамент сквозной представляет собой документ, на основании которого грузы транспортируются из порта погрузки в пункт назначения двумя или более судоходными линиями, взаимодействующими в соответствии с соглашением. Сквозной коносамент может оформлять перевозки и другими видами транспорта.

Коносамент, не содержащий каких-либо оговорок перевозчика, ставящих под сомнения количество принятого к перевозке груза или указывающих о потере качества товара и дефектах упаковки, называется чистыл коносаментом.

Коносамент в линейном судоходстве содержит в себе большее число условий по сравнению с коносаментом, используемым 8 трамповом сообщении.

При линейном судоходстве перевозки осуществляются на устойчивых географических направлениях международной торговли готовой промышленной продукцией и полуфабрикатами, суда функционируют по расписанию.

Трамповое судоходство представляет судоходство без расписания, не связанное с постоянным районом плавания, а также с заранее установленными портами отправления и назначения.

Основными реквизитами коносамента согласно Кодексу торгового мореплавания, действующему в РФ, являются: наименование судна (если груз принят к перевозке на определенном судне), перевозчик и отправитель, место приема или погрузки груза, место назначения груза (либо, при наличии чартера, место назначения или направления судна), наименование получателя (именной коносамент) или указание, что коносамент выдан «приказу отправителя», либо наименование получателя с указанием, что коносамент выдан «приказу получателя» (ордерный коносамент), или указание, что коносамент выдан на предъявителя (коносамент на предъявителя), наименование груза, имеющейся 
на нем марки, число мест либо количество и/или мера (вес, объем), вес, фрахт и другие причитающиеся перевозчику платежи, время и место выдачи коносамента, число составленных экземпляров коносамента, подпись капитана или иного представителя перевозчика.

В международных торговых сделках наибольшее распространение получил исключительно «чистый коносамент», состоящий из набора перевозочных документов: упаковочного листа, отгрузочной спецификации, сертификата качества, страхового полиса, разрешения на отгрузку, гарантийного письма (обязательства грузоотправителя возместить перевозчику ущерб в результате включения неточных сведений о грузе), товарной накладной (счета-фактуры). Коносамент выписывается в шести экземплярах, два из которых - оригиналы.

Процеес доставки груза при железнодорожных, автомобильных и авиаперевозках сопровождается оформлением транспортной накладной, кроме того, дополняется отгрузочными и страховыми сертификатами.

В большинстве случаев внешнеторговые перевозки требуют транзитного сертификата, который дает право на транзитный провоз груза через территорию других государств, удостоверяя оплату сквозного международного транспортного тарифа или книжки МДП в рамках Таможенной конвенции о международной перевозке грузов (1975 г.).

Транспортная накладная (железнодорожная, автотранспортная, авиагрузовая) является договором перевозки, который оформляется соответствующей транспортно-экспедиционной компанией и регулирует отношения между перевозчиком, отправителем и получателем груза, опираясь на ранее оформленный счет-фактуру или предварительный счет.

Накладные составляются в нескольких экземплярах оригинала (в трех при авиаперевозках и пяти при железнодорожных), предназначенных для каждого из участников договора и сопровождения груза.

Типовым товаросопроводительным документом является отгрузочная специффикация на каждую партию товара. В случае формирования партии из 
отдельных грузовых мест оформляется поместная спещиификацุия.

Документ, подтверждающий вес поставляемого груза и весовой объем каждого места в составе отдельной партии, - сертификат веса оформляется в местах отгрузки, перевалки или выгрузки товара и признается бесспорным доказательством веса.

Обязательным документом в процессе поставки выступает страховой полис, который выдается страховщиком груза в лице страховой компании и удостоверяет договор страхования и его условия. Под действие генерального полиса подпадает страховой сертификат. Он выдается страховщиком страхователю в качестве подтверждения страхования отдельной партии товара или удостоверения факта процедуры страхования и выдачи полиса.

Извещуение об отгрузке подтверждает фактически произведенную отгрузку импортного товара из порта экспортера на станцию назначения получателя груза и высылается покупателю продавцом по почте до момента выставления счета, перед или одновременно с отправкой товара.

Извещцение о поставке служит официальным уведомлением покупателя о доставке товара покупателю в срок, указанный в контракте.

Заключительная стадия подготовки коммерческой сделки завершается процедурой выставления счета, т.е. выпиской товарных документов продавцом на имя покупателя, удостоверяющих поставку и стоимость, и передачей их в уполномоченный банк для получения платежа против документов в соответствии с формой расчета, зафиксированной в контракте. В числе таких документов готовятся следующие.

Дебет-нота - извещение одной из сторон сделки, чаще всего покупателя поставщиком, о записи в дебет-счета суммы долга, требующего погашения. При отсутствии возражений со стороны последнего покупатель направляет в свою очередь кредит-ноту, подтверждая свое согласие на оплату. Она также может быть выставлена продавцом (поставщиком) покупателю в случае возврата поставленных ранее товаров (например, поврежденных при транспортировке) или, если имела место переплата со стороны покупателя, 
части поставки. Подобные ноты имеют место в системе расчета по открытому счету. Расписка кредитора в подтверждение получения уплаты в счет долга оформляется официальным документом — квитанцией.

Выписка из счета — это уведомление, предназначенное для покупателя от лица продавца (или его уполномоченного банка), в котором представлены сведения о состоянии расчетного счета, перечислены все расчетные операции, произведенные за определенный промежуток времени, с указанием дат и сумм по каждому из выставленных счетов за поставленный товар с момента последней выписки из расчетного счета, а также сведения о предоставленных и полученных скидках и фактический остаток средств на расчетном счете в конце каждого периода поставки.

Основным расчетным документом является коммерческий счет, содержащий требования продавца к покупателю об уплате указанной суммы причитающегося платежа за поставленный товар. Его реквизиты — цена за единицу продукции, общая сумма счета или платежа, базисные условия поставки, способ платежа, форма расчета, наименование банка, в котором должен совершаться платеж (банк-плательщик).

В случае поставки товара за рубеж на условиях консигнации оформляется счет продаж, который после реализации товара агент (консигнатор) высылает владельцу товара - консигнанту (принципалу). В нем указываются: наименование и тип проданного изделия; доход от продаж (продажная цена товара); расходы, подлежащие возмещению из сумм, полученных от продаж; комиссионное вознаграждение агента; чистая прибыль. Обычно счет продаж сопровождает соответствующий платеж в форме предъявительского векселя.

В заключение характеристики этапов подготовки внешнеторговой сделки следует обратить особое внимание на специфические моменты оформления поставок готовой промышленной продукции - машин и оборудования. Это объясняется тем, что предметом сделок выступают не столько сама поставляемая продукция и связанные с ней работы и услуги, сколько документы, отражающие фактические процессы движения данных 
продуктов - выполняемых работ и предоставляемых услуг. К числу основных документов оперативного учета выполнения подобных контрактных обязательств относятся:

- контракт и дополнения к нему в виде технических документов и спецификаций;

- генеральный заказ-наряд;

- заказы на изготовление оборудования;

• поручения на выполнение проектной документации;

- поручения на командирование представителей экспортера для обучения иностранных специалистов;

- протоколы (акты) передачи проектных материалов;

- акты, подтверждающие работу по обеспечению установки машин и оборудования, и об окончании обучения иностранных специалистов;

• протоколы гарантийных испытаний оборудования;

- рекламные акты.

Кроме того, при сделках, связанных с поставками оборудования, применяются товарораспорядительные документы, которые можно разделить на четыре группы:

1) товаросопроводительнье документы: сертификат качества товара; отгрузочная спецификация; упаковочный лист; комплектовочная ведомость;

2) технические документы: паспорт машины (оборудования); формуляры и описание изделий; чертежи; инструкции по монтажу, управлению, ремонту.

Все документы, связанные с поставками оборудования, передачей проектной документации и командированием специалистов для его монтажа и технического содействия в эксплуатации, должны оформляться своевременно и безукоризненно, составляются на специальных бланках, отпечатанных типографским способом, исключая подчистки и исправления;

3) транспортные документы: квитанция железнодорожной накладной внутреннего сообщения; дубликат международной железнодорожной 
накладной, если товар перевозится без перевалки от завода-изготовителя до станции назначения на территории иностранного заказчика; багажная квитанция; коносамент (при морских перевозках) и другие документы, которые оформляются при автомобильных или авиационных перевозках;

4) расчетные документы: счет - платежное требование или коммерческий счет поставщика за отгруженное оборудование (материалы), расчетно-платежные поручения банкам в зависимости от формы расчетов.

\section{Контрольные вопросы}

1. В чем заключается отличие ВЭД от ВЭС?

2. Когда и в связи с чем в российской практике стало широко использоваться понятие «внешнеэкономическая деятельность?

3. В каком федеральном законе и когда было впервые расшифровано понятие ВЭД?

4. Назовите отличительные особенности ВЭД.

5. Через совокупность каких функций реализуется ВЭД?

6. Что понимается под валютным фондом?

7. Из каких элементов состоит ВЭД предприятий?

8. Назовите и охарактеризуйте основные виды ВЭД.

9. Чем форма ВЭД отличается от вида?

10.Какова роль во ВЭД приграничной и прибрежной торговли и особых экономических зон?

11.Каковы задачи ВЭД?

12.Перечислите объекты ВТД и охарактеризуйте содержание внешней торговли по каждому объекту.

13. Каково соотношение между понятиями «внешнеэкономическая деятельность», «внешнеэкономическая операция», «внешнеторговая операция», «внешнеторговая сделка»?

14.Назовите виды внешнеторговых операций. 
15.Что понимается под внешнеторговой сделкой и внешнеторговым контрактом?

16. Назовите этапы подготовки и проведения экспортной и импортной сделки.

17.В чем отличие твердой оферты от свободной?

18.Назовите основные способы заключения внешнеторговой сделки.

19.Какова структура внешнеторгового контракта и чем она определяется?

20.Какие важные моменты, связанные с поставкой товара, регламентирует ИНКОТЕРМС-2000?

21.На какие группы можно подразделить документы в составе внешнеторговых сделок?

22.Перечислите и охарактеризуйте товаросопроводительные документы?

23.Назовите и охарактеризуйте транспортные документы в составе внешнеторговых сделок.

24.Какие документы используются для подтверждения страны происхождения товаров?

25.Какова роль и функции коносамента?

26.В чем заключаются особенности оформления сделок с готовой продукцией?

\section{Примеры решения задач}

\section{Задача 1}

Заключить внешнеторговый контракт на поставку товара (технологического оборудования) и предоставление сопутствующих поставке услуг на территории Российской Федерации. Подобная задача на практике является не столь простой ввиду несовершенства действующего внешнеторгового законодательства и существующих противоречий между национальными законодательными актами и международными соглашениями, 
например, межгосударственными соглашениями о двойном налогообложении между двумя странами (Россией и Японией и т. д.).

\section{Начальные условия задачи:}

a) продавец - иностранная компания (нерезидент), поставляющая товар и оказывающая услуги на территории РФ;

б) покупатель - российская компания (резидент) - участник ВЭД;

в) товар — технологическое оборудование;

г) услуги - шеф-монтажные работы, тестирование оборудования, сдача в эксплуатацию, гарантийный ремонт.

\section{Варианты решения задачи:}

Вариант 1. Заключить внешнеторговый контракт на поставку (импорт) товара в РФ и отдельный контракт на оказание услуг на территории РФ;

Вариант 2. Заключить один единый внешнеторговый контракт на поставку оборудования с оказанием услуг покупателю продавцом;

Вариант 3. Заключить внешнеторговый контракт на поставку (импорт) товара в РФ между продавцом и покупателем, а также отдельный (рублевый) контракт на оказание услуг на территории РФ между покупателем (резидентом) и российской компанией-посредником (резидентом), представляющим интересы продавца (нерезидента), например, с дочерней компанией продавца, дистрибьютором продавца на территории РФ. Возможно также использовать представительство продавца на территории РФ, однако этот вариант нежелателен, так как такое представительство по своему юридическому статусу не является российским юридическим лицом, что накладывает определенные ограничения на ведение его коммерческой деятельности.

\section{Задачи для самостоятельного решения}

Задача 1. Во внешнеторговом контракте условие доставки указывается на условиях CIP, а цена товара - на условиях FOB. Прокомментируйте правильность или неправильность данного положения в контракте.

Задача 2. Товар находится в порту отправления. Вы, Экспортер, предлагаете базисные условия поставки с наименьшей для себя 
ответственностью и в то же время опасаетесь потерять свою долю выручки от услуг по перевозке и страхованию товара.

Поясните ваш подход к выбору базиса поставки.

\section{Контрольные тесты}

1. Установите правильную последовательность категорий международных коммерческих терминов (ИНКОТЕРМС-2000):
a) основной фрахт не оплачен (группа F);
б) отправление (группа Е);
в) прибытие (группа D);
г) основной фрахт оплачен (группа C).

2. Установите правильную последовательность базисных условий поставки (ИНКОТЕРМС-2000) в зависимости от увеличения стоимости (по нарастающей):
a) CIF;
б) DDU;
в) $\mathrm{EXW}$;
г) $\mathrm{FOB}$;
д) $\mathrm{DDP}$.

3. ВЭД для большинства российских предприятий является:
а) особым видом производственно-хозяйственной деятельности;
б) основным элементом функций менеджмента;
в) частью их производственно-коммерческой деятельности;
г) предметом сделки купли-продажи.

4. Валютные и финансово-кредитные операции в качестве вида ВЭД предприятий и фирм не следует рассматривать:

а) как сопровождающие любую внешнеторговую сделку в виде финансовых обязательств;

б) в качестве самостоятельных специфических видов ВЭД в 
финансово - банковской сфере;

в) в виде валютных операций, совершаемых в целях избежания курсовых потерь;

г) в виде страховых операций.

5. Выбор предмета сделки относится к функции:

а) социальной;

б) оперативно-коммерческой;

в) организационно- экономической;

г) производственно-хозяйственной.

6. Кто в области государственного регулирования внешнеторговой деятельности вводит количественные ограничения экспорта и импорта в соответствии с федеральными законами?

а) Президент РФ;

б) Министерство промышленности и торговли;

в) Министерство финансов РФ;

г) Правительство РФ.

7. Какое из определений внешнеторговой деятельности является правильным?

a) ВТД - это предпринимательство в области обмена товарами, работами, услугами, информацией и результатами интеллектуальной деятельности между производственными структурами внутри государства;

б) ВТД - это вид деятельности, смысл которой состоит в безусловном \} обеспечении экспортных поставок для государственных нужд;

в) ВТД - это деятельность по осуществлению сделок в области внешней торговли товарами, услугами, информацией и интеллектуальной собственностью;

г) ВТД - это процесс международного обмена товарами.

8. К ВЭД не относится:

а) производственно-хозяйственная функция;

б) оперативно-коммерческая функция; 

в) организационно-экономическая функция;
г) организационно-кадровая функция.

9. Обеспечение межправительственных торговых соглашений России относится к:
а) внешней торговле;
б) ВЭД;
в) $\mathrm{B} Э \mathrm{C}$;
г) внешнеторговой деятельности.

10. Планирование внешнеторговой операции является элементом функции ВЭД:
а) организационно-экономической;
б) производственно-хозяйственной;
в) оперативно-коммерческой;
г) социально-экономической.

11. Одна из форм сотрудничества между иностранными партнерами в различных, но конструктивно связанных между собой процессах технологического разделения труда в составе ВЭД предприятий и фирм - это:
а) международное инвестиционное сотрудничество;
б) международная производственная кооперация;
в) валютные и финансово-кредитные операции;
г) внешнеторговая деятельность.

12. Базируется на критериях предпринимательской деятельности, структурной связи с производством и отличается правовой и экономической автономностью - это:
a) $\mathrm{B} Э \mathrm{C}$;
б) внешняя торговля;
в) международная торговля;
г) ВЭД.

13. Какой документ содержит общепринятые обычаи международной 
торговли, которые принято называть базисными условиями поставки товара?
а) Книжка МДП.
б) Генеральный полис.
в) ИНКОТЕРМС - 2000 .
г) Контракт купли - продажи.

14. Предложение продавца, направленное конкретному покупателю и содержащее срок для ответа, называется:
a) оферта;
б) акцепт;
в) твердая оферта;
г) свободная оферта.

15. Внешнеторговым контрактом можно назвать любой контракт, заключенный между контрагентами из разных стран:
а) на товары в материально - вещественной форме, услуги, результаты творческой деятельности;

б) на товары в материально - вещественной форме и результаты творческой деятельности;

в) только на товары в материально - вещественной форме;

г) на товары в материально - вещественной форме и услуги.

16.Во внешнеторговых перевозках важнейшим документом, удостоверяющим наличие договора перевозки морским или речным транспортом и конкретизирующим его условия, является:
a) чартер;
б) коносамент;
в) генеральный акт;
г) манифест.

17.Внешнеторговая сделка может быть оформлена следующими документами: 1) контракт, 2) оферта продавца и акцепт ее покупателем, 3) подтверждение продавцом заказа покупателя. 

а) только 1 .
б) 1,2 и 3 .
в) 1 и 2.
г) 1 и 3.

18. Базисные условия поставки ИНКОТЕРМС носят характер:
а) обязательный для поставщика товара;
б) рекомендательный;
в) обязательный для покупателя, если он самостоятельно перевозит товар;
г) обязательный для обеих сторон.

19. Твердая оферта делается:
а) одному возможному покупателю, но устанавливается твердый срок для запроса - контроферты покупателя;
б) нескольким возможным покупателям, но предпочтение отдается тому из них, от кого раньше будет получено согласие с условиями оферты;
в) нескольким возможным покупателям, но имеет определенный срок действия;
г) одному возможному покупателю. 


\section{Глава 2. Регулирование и контроль внешнеэкономической деятельности}

\section{1.Цели и методы государственного регулирования ВЭД}

Во всех странах внешнеэкономическая деятельность рассматривается как часть внешней политики государства, а также национальной экономической политики, поэтому подлежит регулированию со стороны государства. Государственное регулирование ВЭД осуществляется с помощью совокупности методов и средств для проведения определенной внешнеэкономической политики.

Основные цели регулирования ВЭД состоят в следующем:

— использование внешнеэкономических связей для ускорения создания в России развитой рыночной экономики;

— содействие повышению производительности труда и качества национальной продукции путем приобретения лицензий и патентов, закупок новых технологий, качественных комплектующих, сырья и материалов, включения российских предприятий в мировую конкуренцию;

— создание условий доступа российских предпринимателей на мировые рынки посредством оказания государственного, организационного, финансового, информационного содействия;

- защита национальных внешнеэкономических интересов, защита внутреннего рынка;

- создание и поддержание благоприятного международного режима во взаимоотношениях с различными государствами и международными организациями.

Основные принципы государственного регулирования внешнеэкономической деятельности в Российской Федерации:

- защита государством прав и законных интересов участников внешнеторговой деятельности, а также прав и законных интересов российских производителей и потребителей товаров и услуг;

- единство

системы 
внешнеэкономической деятельности;

• единство таможенной территории Российской Федерации;

- приоритет экономических мер регулирования;

- равенство всех участников ВЭД и их недискриминация, если другое не предусмотрено федеральным законом;

• взаимность в отношении другого государства (группы государств);

- исключение неоправданного вмешательства государства и его органов во ВЭД, нанесения ущерба ее участникам и экономике страны в целом;

- обеспечение выполнения обязательств Российской Федерацией по международным договорам Российской Федерации и осуществление возникающих из этих договоров прав Российской Федерации;

• выбор мер государственного регулирования по принципу достаточности;

• гласность в разработке, принятии и применении мер государственного регулирования внешнеторговой деятельности;

- обоснованность и объективность применения мер государственного регулирования внешнеторговой деятельности;

- обеспечение обороны страны и безопасности государства;

- обеспечение права на обжалование в судебном или ином установленном законом порядке незаконных действий (бездействия) государственных органов и их должностных лиц;

- единство применения методов государственного регулирования внешнеторговой деятельности на всей территории Российской Федерации.

Государственное регулирование ВЭД осуществляется с помощью широкого круга мер, число которых постоянно растет. Применяемые государством разнообразные инструменты влияния на внешние экономические связи можно подразделить на следующие группы:

1) все меры могут быть разделены, в зависимости от направленности действия на экономические процессы, на протекционистские и либерализационные. Протекционистские меры направлены на защиту 
внутреннего рынка от иностранной конкуренции. Меры либерализации в противоположность этому направлены на снятие, снижение ограничений во внешней торговле, что приводит к росту конкуренции со стороны иностранных компаний. В современной мировой экономике и в политике любого государства постоянно присутствуют эти две противоречивые тенденции: протекционизм и либерализация;

2) все меры в зависимости от характера воздействия на экономические процессы могут быть разделены на административные и экономические.

Государственное регулирование внешней торговли основывается на сочетании экономических (таможенно-тарифных и финансовых) и административных методов воздействия.

Экономические методы характеризуются воздействием государства на деятельность хозяйствующих субъектов способами, с помощью которых участник, самостоятельно оценивая результаты своей деятельности, видит их целесообразность и выгоду после подведения баланса расходов и полученных доходов.

Тарифное регулирование представляет систему ставок экспортной и импортной таможенных пошлин, которые можно варьировать законодательно установленными методами в сторону повышения или понижения их, а также применением тарифных льгот и преференций.

Кроме того, к экономическим методам относятся иные меры финансового, налогового свойства, которые применяются от имени государства для стимулирования внешнеэкономической деятельности в целом и к внешнеторговым операциям в частности, например государственное кредитование производства отдельных отраслей, применение финансовых стимулов через создание привлекательности иностранных инвестиций в развитие конкретного производства. Механизмы инвестиционных налоговых кредитов также необходимо отнести к экономическим методам государственного воздействия на внешнеэкономическую деятельность, позволяющим создать условия для технического перевооружения производства 
и модернизации основных фондов. Налоговые стимулы, предусмотренные Федеральным законом от 22 июля 2005 г. № 116-Ф3 «Об особых экономических зонах в Российской Федерации» для развития производства на территориях свободных экономических зон, также являются мерами экономического воздействия на внешнеэкономическую деятельность, способствующими привлечению иностранного капитала к участию в производстве. Кроме того, применение мер государственного воздействия в комплексе открывает возможности импорта современных технологий на территории свободных экономических зон, что также положительно влияет на прогрессивную направленность изменений на территориях, как правило, признанных нуждающимися в экономическо-технических преобразованиях.

В налоговой политике Российской Федерации применяются налоговые стимулы при осуществлении непосредственно внешнеторговых операций. К таким стимулам необходимо отнести стимулирование экспорта товаров, работ и услуг путем применения нулевой налоговой ставки при исчислении НДС, и право налогоплательщика на возмещение сумм взысканного налога при производстве экспортного товара, a также работ, участвующих в его производстве, транспортировке по территории страны и фактическом вывозе за пределы таможенной территории Российской Федерации.

В налоговые формы государственного воздействия на внешнеторговые операции как часть внешнеэкономической деятельности необходимо включить взимание косвенных налогов (НДС и акциза) при импорте товаров, а также механизмы применения пониженных ставок при обложении НДС при таможенном оформлении определенных категорий товаров (товаров медицинского предназначения, основной категории продуктов питания, а также детских товаров).

К налоговым мерам воздействия на внешнеэкономическую деятельность необходимо отнести и применение налоговых льгот при ввозе технологического оборудования иностранного производства в качестве материальных ресурсов, формирующих уставные фонды российских субъектов 
хозяйствования, образованных с участием иностранного капитала.

Следовательно, экономический метод воздействия представляет конгломерат тарифного регулирования и системы косвенных налогов, применяемых во внешнеторговой деятельности.

Административные методы государственного регулирования внешнеторговой деятельности представляют систему нетарифного регулирования внешнеторговых операций (квотирование, лицензирование, сертификация, другие регистрационные и разрешительные меры), а также методов государственного воздействия разрешительно-запретительного свойства, например требования по экологической экспертизе при проведении проектно-изыскательских работ в рамках программы добычи полезных ископаемых по системе раздела продукции;

3) в зависимости от характера и разновидности применяемых приемов регулирование внешнеторговой деятельности согласно Закону РФ «Об основах государственного регулирования внешнеторговой деятельности» осуществляется посредством:

- таможенно-тарифного регулирования;

- нетарифного регулирования;

• запретов и ограничений внешней торговли услугами и интеллектуальной собственностью; мер экономического и административного характера, способствующих развитию внешнеторговой деятельности и предусмотренных законом.

Система таможенно-тарифного регулирования внешнеторговой деятельности в России, как и в международной практике, базируется на экономических принципах и состоит из нескольких элементов: таможенных тарифов и таможенных пошлин, классификаторов ТН ВЭД, оценки таможенной стоимости, режима преференций (режима наибольшего благоприятствования и общего режима преференций), процедуры подтверждения страны происхождения импортируемой продукции, таможенных режимов.

В законе РФ“'Об основах государственного регулирования внешнеторговой 
деятельности" под таможенно-тарифным регулированием понимается метод государственного регулирования внешней торговли товарами, осуществляемый путем применения ввозных и вывозных таможенных пошлин.

Таким образом, экспортные и импортные таможенные пошлины являются инструментом таможенно-тарифного регулирования внешнеторговой деятельности. Регулирование с помощью таможенных пошлин, взимаемых при ввозе или вывозе товаров, или только при ввозе является наиболее распространенной и общепринятой формой таможенно-тарифного регулирования. Величина (или ставка) таможенной пошлины при ввозе определяет степень закрытости или доступности внутреннего рынка для иностранных товаров. Сведенные воедино ставки таможенных пошлин называются таможенным тарифом, поэтому регулирование с помощью тарифа называется таможенно-тарифным регулированием.

Правовую основу таможенно-тарифного регулирования составляют Таможенный кодекс (ТК) РФ, закон РФ «О таможенном тарифе» (от 21 мая 1993 г.), закон РФ «Об основах государственного регулирования внешнеторговой деятельности» (от 8 декабря 2003 г.), закон РФ «О специальных защитных, антидемпинговых и компенсационных мерах при импорте товаров» (от 8 декабря 2003 г.), а также система подзаконных нормативно-правовых актов, издаваемых Правительством РФ, Министерством экономического развития и торговли РФ и изданных ранее ГТК РФ.

Таможенная пошлина - это обязательный платеж в федеральный бюджет, взимаемый таможенными органами при ввозе товаров на таможенную территорию Российской Федерации или вывозе товаров с этой территории, а также в иных случаях, установленных таможенным законодательством Российской Федерации, в целях таможенно - тарифного регулирования внешнеторговой деятельности в экономических интересах Российской Федерации. К таможенным пошлинам относятся ввозная таможенная пошлина, включая сезонные пошлины, и вывозная таможенная пошлина. Величину ставок таможенных пошлин определяет Правительство РФ. 
Таможенный тариф представляет собой инструмент торговой политики и государственного регулирования внутреннего рынка российских товаров при его взаимосвязи с мировым рынком. Как элемент таможенного дела, он помогает определить объем таможенных платежей, подлежащих уплате субъектом ВЭД. Основой таможенного тарифа является Товарная номенклатура внешнеэкономической деятельности, которая в соответствии с ТК применяется для осуществления мер таможенно-тарифного регулирования внешнеторговой и иных видов внешнеэкономической деятельности. Суть ее состоит в том, что в отношении каждого перемещаемого товара определяется его классификационный код, который влияет на ставку таможенной пошлины.

Основные цели таможенного тарифа:

- рационализация товарной структуры ввоза товаров в РФ;

- поддержание рационального соотношения вывоза и ввоза товаров, валютных доходов и расходов на территории РФ;

- создание условий для прогрессивных изменений в структуре производства и потребления товаров;

- зашита экономики РФ от неблагоприятного воздействия иностранной конкуренции;

- обеспечение условий для эффективной интеграции РФ в мировую экономику.

Таможенный тариф применяется в отношении ввоза товаров на таможенную территорию и вывоза товаров с этой территории. Существует отдельно импортный таможенный тариф с импортными таможенными пошлинами и отдельно экспортный таможенный тариф с экспортными таможенными пошлинами.

Таможенный тариф РФ включает следующие элементы: код товара по ТН ВЭД РФ, наименование товара, дополнительные единицы измерения, ставку таможенной пошлины.

Импортный таможенный тариф в России применяется с 1992 г. и с января 2001 г. унифицирован до четырех основных таможенных ставок- 5, 10, 
15 и 20\%. Экспортные таможенные тарифы введены в российскую внешнеторговую практику в 1991 г. и применялись до 1 июля 1996 г. С 1 января 1999 г. экспортные тарифы вновь введены Правительством РФ и применяются по настоящее время. Они касаются небольшого перечня экспортных товаров, включая сырьевую продукцию природного и растительного происхождения, цветные металлы и лом.

Наряду с ввозными и вывозными пошлинами законодательством РФ предусмотрены следующие виды пошлин: сезонные и особые пошлины. Особые виды пошлин подразделяются на специальные, антидемпинговые и компенсационные.

Введение сезонных пошлин предусмотрено в соответствии с законом РФ «О таможенном тарифе» в качестве меры оперативного регулирования экспортных и импортных операций. Сезонные пошлины применяются в отношении сельскохозяйственных продуктов и других товаров. Механизм использования сезонных пошлин предполагает, что в период их действия ставки таможенных пошлин, установленные по данным товарным позициям в таможенном тарифе, не применяются.

В соответствии с ФЗ "Об основах государственного регулирования внешнеторговой деятельности" специальные, антидемпинговые и компенсационные пошлины отнесены к мерам нетарифного регулирования внешней торговли товарами и применяются для защиты экономических интересов российских производителей товаров.

Правовые основы введения в РФ специальных, антидемпинговых и компенсационных пошлин установлены Ф3 "О специальных защитных, антидемпинговых и компенсационных мерах при импорте товаров” от 8 декабря 2003 г. № 165-Ф3.

Специальная пошлина - пошлина, которая применяется при введении специальной защитной меры и взимается таможенными органами РФ независимо от взимания ввозной таможенной пошлины.

Специальная защитная мера это мера по ограничению возросшего 
импорта на таможенную территорию РФ, которая применяется по решению Правительства РФ посредством введения импортной квоты или специальной пошлины, в том числе предварительной специальной пошлины. Предварительная специальная пошлина взимается до получения результатов расследования. Суммы от взимания предварительной специальной пошлины помещаются на депозит таможенного органа. По результатам проведенного расследования, находящиеся на депозите таможенного органа суммы временной специальной пошлины перечисляются в федеральный бюджет либо возвращаются плательщику в соответствии с порядком возврата таможенных платежей. Срок действия предварительной специальной пошлины не должен превышать двести дней.

Антидемпинговая пошлина - пошлина, которая применяется при введении антидемпинговой меры и взимается таможенными органами РФ независимо от взимания ввозной таможенной пошлины.

Антидемпинговая мера - мера по противодействию демпинговому импорту, которая применяется по решению Правительства РФ посредством введения антидемпинговой пошлины, в том числе предварительной антидемпинговой пошлины, или одобрения ценовых обязательств, принятых экспортером.

Антидемпинговая мера может быть применена к товару, являющемуся предметом демпингового импорта, в случае, если по результатам расследования, проведенного органом, проводящим расследования, установлено, что импорт такого товара на таможенную территорию РФ причиняет материальный ущерб отрасли российской экономики, создает угрозу причинения материального ущерба отрасли российской экономики или существенно замедляет создание отрасли российской экономики.

Под демпинговым импортом понимается импорт товаров на таможенную территорию РФ по цене ниже нормальной стоимости такого товара.

Материальный ущерб отрасли российской экономики может выражаться в сокращении объема производства аналогичного товара в РФ и объема его 
реализации на рынке РФ, снижении рентабельности производства такого товара, негативном воздействии на товарные запасы, занятость, уровень заработной платы в данной отрасли российской экономики, уровень инвестиций в данную отрасль российской экономики.

Предварительная антидемпинговая пошлина вносится в соответствии с положениями таможенного законодательства РФ на депозит таможенного органа. Суммы предварительной антидемпинговой пошлины не перечисляются в федеральный бюджет до принятия по результатам расследования, окончательного решения о применении антидемпинговой меры.

Компенсационная пошлина - пошлина, которая применяется при введении компенсационной меры и взимается таможенными органами РФ независимо от взимания ввозной таможенной пошлины.

Компенсационная мера - мера по нейтрализации воздействия специфической субсидии иностранного государства (союза иностранных государств) на отрасль российской экономики, применяемая по решению Правительства РФ посредством введения компенсационной пошлины, в том числе предварительной компенсационной пошлины, либо одобрения обязательств, принятых уполномоченным органом субсидирующего иностранного государства (союза иностранных государств) или экспортером.

Компенсационная мера может быть применена к импортированному товару, при производстве, экспорте или транспортировке которого использовалась специфическая субсидия иностранного государства (союза иностранных государств), в случае, если по результатам расследования, проведенного органом, проводящим расследования, установлено, что импорт такого товара на таможенную территорию РФ причиняет материальный ущерб отрасли российской экономики, создает угрозу причинения материального ущерба отрасли российской экономики или существенно замедляет создание отрасли российской экономики.

Специфическая субсидия иностранного государства (союза иностранных государств) - это субсидия, доступ к которой ограничен и которая 
предоставляется конкретному производителю и (или) экспортеру, или конкретному союзу (объединению) производителей и (или) союзу (объединению) экспортеров, или конкретной отрасли экономики либо направлена на стимулирование экспорта товара или на замещение импорта товара.

Ставки таможенных пошлин устанавливаются решениями Правительства РФ, являются едиными и не подлежат изменению в зависимости от лиц, перемещающих товары через таможенную границу, видов сделок и других факторов (за исключением случаев, предусмотренных Законом РФ «О таможенном тарифе»).

В РФ применяются следующие виды ставок пошлин:

- адвалорные, начисляемые в процентах к таможенной стоимости облагаемых товаров;

- специфические, начисляемые в установленном размере за единицу облагаемых товаров;

- комбинированные, сочетающие оба названных вида таможенного обложения.

Ставки таможенных пошлин применяются на день принятия таможенной декларации таможенным органом к таможенному оформлению (в исключительных случаях при их изменении - по дате пересечения таможенной границы РФ при наличии специального указания).

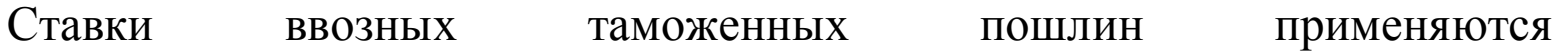
дифференцированно в зависимости от страны происхождения товаров:

- в отношении товаров, происходящих из государств, которым в торгово-политических отношениях РФ предоставляет режим наибольшего благоприятствования (РНБ) на основе подписанных с ними торговых договоров и соглашений (свыше 120 стран), применяются ставки ввозных пошлин, установленные Правительством РФ;

- в отношении товаров, происходящих из государств, которым в торгово-политических отношениях РФ не предоставляет режим наибольшего 
благоприятствования, применяются ставки ввозных таможенных пошлин, установленные Правительством РФ, увеличенные в два раза;

- в отношении товаров, происходящих из развивающихся стран, применяются ставки ввозных таможенных пошлин, установленные Правительством РФ, уменьшенные на 25\% (свыше 100 стран);

- в отношении товаров, происходящих из наименее развитых стран, применяется полное освобождение от уплаты ввозной таможенной пошлины (свыше 40 стран);

- в отношении товаров, происходящих и ввозимых из государств-участников СНГ, в соответствии с двухсторонними соглашениями о свободной торговле ввозные таможенные пошлины не взимаются.

Таможенная пошлина может уплачиваться по желанию плательщика как в рублях РФ, так и в иностранных валютах, курсы которых котируются ЦБ РФ.

В соответствии с законом Российской Федерации «О таможенном тарифе» под тарифной льготой (тарифной преференцией) понимается предоставляемая на условиях взаимности или в одностороннем порядке при реализации торговой политики Российской Федерации льгота в отношении товара, перемещаемого через таможенную границу Российской Федерации, в виде возврата ранее уплаченной пошлины, освобождения от уплаты пошлины, снижения ставки пошлины, установления тарифных квот па преференциальный ввоз (вывоз) товара. Тарифная льгота — разновидность налоговых льгот.

Возврат ранее уплаченной таможенной пошлины предусматривается отдельными таможенными режимами, закрепленными в Таможенном кодексе, например, реимпорта, реэкспорта, беспошлинной торговли. Полное освобождение (в том числе полное условное освобождение) от уплаты таможенной пошлины допускается в соответствии с таможенными режимами международного таможенного транзита, переработки на таможенной территории, таможенного склада, реимпорта, реэкспорта и т.д. Частичное освобождение (в том числе частичное условное освобождение) предоставляется в соответствии с таможенными режимами переработки для внутреннего 
потребления, переработки вне таможенной территории, временного ввоза.

В соответствии с законом РФ “О таможенном тарифе” от уплаты таможенной пошлины освобождаются:

1. Транспортные средства, осуществляющие международные перевозки грузов, багажа и пассажиров, а также предметы материально-технического снабжения и снаряжения, топливо, продовольствие и другое имущество, необходимое для их нормальной эксплуатации на время следования в пути, в пунктах промежуточной остановки или приобретенное за границей в связи с ликвидацией аварии (поломки) данных транспортных средств.

2. Продукция морского промысла российских и арендованных (зафрахтованных) российскими лицами судов, ввозимая на таможенную территорию Российской Федерации.

3. Товары, ввозимые на таможенную территорию Российской Федерации или вывозимые с этой территории для официального или личного пользования представителями иностранных государств, физическими лицами, имеющими право на беспошлинный ввоз таких предметов на основании международных соглашений или законодательства Российской Федерации.

4. Валюта РФ, иностранная валюта, а также ценные бумаги в соответствии с законодательными актами Российской Федерации.

5. Товары, подлежащие обращению в собственность государства в случаях, предусмотренных законодательством Российской Федерации.

6. Товары, ввозимые на таможенную территорию РФ в качестве вклада в уставные фонды предприятий с иностранными инвестициями и иностранных предприятий.

7. Товары, ввозимые на таможенную территорию Российской Федерации в качестве гуманитарной помощи и в целях ликвидации последствий аварий, катастроф и стихийных бедствий и др.

В соответствии с ТК РФ таможенные пошлины, налоги не уплачиваются в случае, если общая стоимость товаров, ввозимых на таможенную территорию РФ в течение одной недели в адрес одного получателя, не превышает 
5000 рублей.

Тарифная льгота в виде снижения ставок пошлины предоставляется в отношении товаров, происходящих из развивающихся стран, пользующихся национальной системой преференций РФ. Такие товары облагаются по ставкам в размере $75 \%$ действующих ставок таможенного тарифа.

Установление тарифных квот на преференциальный ввоз (вывоз) товара специфическая для внешнеторговой деятельности налоговая льгота. Под тарифной квотой понимается квота, в пределах стоимости или количества которой импортируемые товары облагаются таможенными пошлинами в обычном размере. Превышение тарифной квоты влечет за собой повышение ставок таможенной пошлины.

Под преференциями понимаются особые (предпочтительные) льготы, предоставляемые одним государством другому на началах взаимности либо в одностороннем порядке без распространения на третьи страны. Такие льготы устанавливаются в отношении всех товаров или их отдельных видов.

Под режим преференциального ввоза могут помещаться: во-первых, товары, происходящие из государств, образующих вместе с Россией зону свободной торговли или таможенный союз, и, во-вторых, товары, происходящие из развивающихся стран - пользователей российской национальной системы преференций.

Национальная система (схема) преференций в отношении товаров, происходящих из развивающихся стран, включает в себя три основных элемента:

- перечень развивающихся стран — пользователей схемой преференций Российской Федерации (свыше 100 стран);

- перечень наименее развитых стран - пользователей схемой преференций Российской Федерации (свыше 40 стран);

- список товаров, на которые преференциальный режим не распространяется.

Преференциальный режим распространяется не на все товары, ввозимые 
на территорию РФ.

Перечень товаров, к которым применяются преференции при ввозе в РФ, определяется Правительством РФ. Этот перечень товаров определен в Приложении 4 к приказу ГТК России от 25 декабря 2003 года N 1539 “О предоставлении тарифных преференций”.

Тарифные преференции (льготы), предусмотренные национальной системой преференций РФ, предоставляются при предъявлении сертификата о происхождении товара по форме «А» только при соблюдении правила «прямой отгрузки и непосредственной закупки».

Правильная классификация перемещаемых через таможенную границу РФ товаров является предпосылкой эффективности внешнеторговой сделки с точки зрения таможенных издержек при ее осуществлении. Классификация товаров, перемещаемых через таможенную границу РФ, осуществляется с применением Товарной номенклатуры внешнеэкономической деятельности России (ТН ВЭД России). Ведение ТН ВЭД, классификация и кодирование товаров являются важными составными элементами таможенного дела. От правильного определения кода того или иного товара зависит обоснованное начисление и взимание таможенных платежей.

ТН ВЭД России - систематизированный перечень товаров, используемый в целях государственного регулирования внешнеэкономической деятельности и включающий кодовое обозначение товара, его наименование и сокращенное обозначение единиц измерения. ТН ВЭД России построена на базе Номенклатуры Гармонизированной системы описания и кодирования товаров (НГС).

Товарная номенклатура внешнеэкономической деятельности утверждается Правительством РФ исходя из принятых в международной практике систем классификации товаров. ТН ВЭД применяется для осуществления мер таможенно-тарифного и нетарифного регулирования внешнеторговой и иных видов внешнеэкономической деятельности, ведения таможенной статистики внешней торговли РФ. Ведение Товарной 
номенклатуры внешнеэкономической деятельности осуществляется таможенными органами РФ. Решения таможенных органов о классификации товаров являются обязательными, декларант вправе обжаловать такие решения.

ТН ВЭД России стала дальнейшим развитием ТН ВЭД СНГ, которая применялась в РФ для классификации товаров в таможенных целях до 1 апреля 2000 года. Переход к ТН ВЭД России был обусловлен тем, что задачи обеспечения оперативного использования мер тарифного и нетарифного регулирования в интересах России требуют дальнейшего развития ТН ВЭД. С введением ТН ВЭД России детализация товарной номенклатуры в интересах России на 10 знаке кодового обозначения может осуществляться только по решению Правительства России.

При таможенном декларировании код товаров определяется декларантом или таможенным брокером и указывается в таможенной декларации. Декларирование товара не своим наименованием, т.е. неправильное указание его кода по ТН ВЭД, является нарушением таможенных правил.

В соответствии с ТК РФ в случае установления нарушения правил классификации товаров при их декларировании таможенный орган вправе самостоятельно осуществить классификацию товаров.

При возникновении сложностей в вопросах определения кода конкретного товара в соответствии с ТН ВЭД участник ВЭД может обратиться в таможенный орган за получением предварительного решения. Для этого участник ВЭД направляет в соответствующий таможенный орган запрос о принятии предварительного решения, составленный в письменной форме. Указанный запрос должен содержать все сведения, необходимые для принятия предварительного решения. К запросу должны прилагаться пробы и образцы товаров, их описание, фотографии, рисунки, чертежи, коммерческие, технические и иные документы.

Если представленные заявителем сведения (в запросе о принятии предварительного решения) недостаточны для принятия предварительного 
решения, таможенный орган в течение 30 дней со дня получения такого запроса уведомляет заявителя о необходимости предоставления дополнительной информации и устанавливает срок для ее предоставления. В случае, если дополнительная информация не представлена в указанный срок, запрос о принятии предварительного решения отклоняется. Однако заявитель может обратиться повторно с запросом о принятии предварительного решения при условии устранения причин, которые послужили основанием для отклонения указанного запроса.

Предварительное решение действует в течение пяти лет со дня его принятия, если оно не изменено или не отозвано либо его действие не прекращено в соответствии с Таможенным кодексом.

Решение о прекращении действия, об изменении или отзыве предварительного решения направляется лицу (участнику ВЭД), которому выдано предварительное решение, в письменной форме не позднее дня, следующего за днем вынесения решения о прекращении действия, об изменении или отзыве предварительного решения.

Прекращение действия предварительного решения принимается, если такое решение принято на основе подложных документов, представленных заявителем. Решение о прекращении действия предварительного решения вступает в силу со дня принятия предварительного решения.

Изменение предварительного решения о классификации товара производится в случае принятия ФТС России обязательного для исполнения таможенными органами решения о классификации отдельных товаров, а также в случае выявления ошибок, допущенных при принятии предварительного решения.

Изменение вступает в силу в срок, указанный в решении об изменении предварительного решения, но не ранее чем через три месяца со дня принятия решения об изменении предварительного решения.

Принятое предварительное решение может быть отозвано:

- в случае изменения Товарной номенклатуры внешнеэкономической 
деятельности, принятия Всемирной таможенной организацией классификационных решений, обязательных для применения в Российской Федерации;

- в случае, если международными договорами Российской Федерации или актами законодательства Российской Федерации, имеющими отношение к вопросам определения страны происхождения товаров, устанавливаются иные требования и условия определения страны происхождения товаров.

Решение об отзыве предварительного решения должно быть принято не позднее трех дней после опубликования вышеперечисленных актов и вступает в силу одновременно с ними.

В ТН ВЭД России строго соблюдается принцип однозначного отнесения товаров к классификационным группировкам, что позволяет отнести товар только к одной классификационной группировке. Происходит это благодаря Основным правилам интерпретации ТН ВЭД России и примечаниям к разделам, группам и субпозициям.

Опубликование ТН ВЭД России обеспечивает ФТС России.

Все товары в ТН ВЭД классифицированы по таким признакам, как происхождение, вид материала, из которого изготовлен товар, назначение товаров, их химический состав, степень обработки (сырье, полуфабрикаты, готовая продукция).

ТН ВЭД России - структурированная номенклатура, т.е. номенклатура с распределением информации по уровням:

раздел 1-й уровень (римские цифры) (не отражается в коде товара);

группа 2-ой уровень (первые 2 цифры кода);

товарная позиция - 3-й уровень (первые 4 цифры кода);

субпозиция 4-й уровень (первые 6 цифр кода); подсубпозиция - 5-й уровень (10-значный код). Длина кодового обозначения товара по ТН ВЭД России составляет 10 
цифровых знаков, причем первые шесть знаков соответствуют кодовому обозначению классификационной группировки товара по НГС. Седьмой и восьмой знаки означают дополнительную детализацию в соответствии с Комбинированной номенклатурой Европейского Союза. Девятый знак соответствует коду товара по ТН ВЭД СНГ. Десятый знак введен постановлением Правительства РФ от 22 февраля 2000 г. N 148 “О таможенном тарифе Российской Федерации - своде ставок ввозных таможенных пошлин и товарной номенклатуре, применяемой при осуществлении внешнеэкономической деятельности”.

Разделы нумеруются римскими цифрами. На уровне разделов товары сгруппированы в соответствии с отраслями промышленности. Так, например, в Разделе IV сгруппирована продукция пищевой промышленности, а в Разделе VI - продукция химической промышленности. ТН ВЭД России включает 21 раздел.

Группы имеют сквозную двузначную арабскую нумерацию, не имеющую связи с нумерацией разделов.

На уровне групп товары детализируются в соответствии:

- с материалом, из которого они изготовлены (например, группа 74 "Медь и изделия из нее");

- с функциями, которые они выполняют (группа 91 "Часы всех видов и их части");

- со степенью обработки (например, группа 10 включает в себя хлебные злаки, группа 11 - продукцию мукомольного производства, а группа 19 - мучные кондитерские изделия).

В некоторых группах существует дополнительный уровень классификации

- подгруппы (например, в группе 28 - "Продукты неорганической химии..."), пронумерованные римскими цифрами.

ТН ВЭД России включает 96 групп.

Каждая товарная позиция имеет четырехзначный номер, первые два знака 
которого - номер группы, включающей данную позицию.

Детализация товаров на уровне товарных позиций осуществляется по более специфическим признакам, чем на предыдущем уровне.

В субпозициях (шестизначный код, первые четыре знака которого совпадают с кодом соответствующей товарной позиции) используются все вышеперечисленные критерии детализации товаров, а также дополнительные признаки.

Подсубпозиции имеют десятизначный код, первые шесть знаков которого совпадают с кодом субпозиции, а четыре последних представляют собой более глубокую детализацию товаров по дополнительным признакам (например, по плотности бумаги в субпозиции 480530 "Бумага и картон немелованные...").

Меры, относимые к нетарифным, отличаются большим разнообразием. Система нетарифных ограничений в России состоит из таких элементов, как: координация доступа экспортеров к трубопроводам, Реестр ФТС России уполномоченных банков, Реестр отраслевых объединений производителейэкспортеров, запреты и запрещения, сертификация, количественные ограничения экспорта и импорта (квотирование, лицензирование, добровольное самоограничение экспорта, тарифные квоты), экспортный и импортный контроль (за поставкой товаров в режиме «особого порядка экспорта», за вывозом лицензируемых товаров, за таможенной стоимостью, за подакцизными товарами, валютный контроль (паспорт сделки экспортной, импортной, бартерной; экспертиза обоснованности задержки валютной выручки), налоговое регламентирование импорта (НДС, акцизы, акцизные марки), антидемпинговые и компенсационные меры)).

Мерами прямого ограничения, направленными на защиту интересов национальной экономики, являются лицензирование и квотирование. Лицензирование как мера государственного регулирования внешнеторговой деятельности применяется в России (СССР) с 1989 г. Лицензирование предполагает, что на экспорт и (или) импорт отдельных товаров необходимо получать у соответствующего государственного органа специальное разрешение 
(лицензию). С помощью лицензирования осуществляется государственная монополия на экспорт и (или) импорт отдельных видов товаров (ст. 24 Закона РФ «Об основах государственного регулирования внешнеторговой деятельности»).

Перечни лицензируемых товаров (работ, услуг) устанавливаются Правительством Российской Федерации.

В настоящее время список товаров, экспорт и (или) импорт которых подлежит лицензированию, включает;

- товары с содержанием драгоценных металлов, драгоценных камней, янтаря, изделий из них;

• лекарственные средства и фармацевтические субстанции;

• радиоактивные вещества и изделия на их основе;

- ядерные материалы, оборудование и соответствующие технологии;

- товары (материалы, оборудование и технологии) двойного применения, т.е. товары, которые имеют мирное назначение, но могут быть применены для создания ядерного, химического, бактериологического и других видов оружия;

• возбудители заболеваний (патогенов) человека, животных и растений;

• опасные отходы;

• порохи промышленного применения, взрывчатые вещества, средства взрывания и пиротехнические изделия;

• озоноразрушающие вещества и продукты, содержащие их;

• наркотические средства, сильнодействующие и ядовитые вещества;

- шифровальные средства (техника, части для нее, пакеты программ, документация);

• спирт этиловый и водка (только импорт);

- древесина ценных пород.

Лицензии выдаются федеральным органом исполнительной власти, на который Правительством РФ непосредственно возложены координация и регулирование внешнеторговой деятельности (в настоящее время Минпромторг РФ), как правило, после согласования с соответствующими министерством и 
ведомствами или их территориальными органами.

Лицензия - официальный документ, разрешающий осуществление экспортных или импортных операций в течение установленного срока. Лицензии могут быть разовыми и генеральными. Разовая лицензия выдается для осуществления экспортной или импортной операции по одному контракту на срок до 12 месяцев (но на срок, не превышающий срок действия контракта). Генеральная лицензия выдается на основании решения Правительства РФ на каждый вид товара на определенный срок.

Другим инструментом прямого количественного ограничения является квотирование (контингентирование). Квоты - это ограничения в стоимостном или физическом выражении, вводимые на импорт или экспорт конкретных товаров на определенный период времени (например, год, полугодие, квартал и другие периоды). В эту категорию входят глобальные квоты, квоты, действующие в отношении отдельных стран, сезонные и так называемые «добровольные» ограничения экспорта. Добровольные ограничения экспорта означают обязательство одного из государств-партнеров или взаимное обязательство ограничить торговлю путем введения квот на экспорт товаров. Специфика этого вида торговых ограничений состоит в том, что торговый барьер, защищающий страну-импортера, вводится на границе экспортирующей, а не импортирующей страны. Например, в феврале 1995 г. было подписано соглашение РФ с ЕОУС, содержащее такое обязательство по некоторым видам изделий из стали. В 1994 г., например, были введены «добровольные» ограничения по поставке в ЕС карбида кремния, алюминия, текстильных товаров.

Аналогично может быть установлен барьер по минимальным ценам на рынке страны-импортера. Это соглашение должно строго соблюдаться экспортирующими фирмами при заключении контрактов. В случае снижения экспортной цены ниже минимального уровня импортирующая страна вводит антидемпинговую пошлину, применение которой может привести вообще к закрытию рынка для страны-экспортера. Хотя данная процедура заключения 
соглашений об установлении минимальных импортных цен, строго говоря, и не является мерой количественного ограничения экспорта, но ее действие аналогично установлению квот в связи с «добровольным» ограничением экспорта.

Меры прямого ограничения экспорта и импорта могут вводиться в исключительных случаях Правительством Российской Федерации. Как сказано в ст. 21 Закона «Об основах государственного регулировании внешнеторговой деятельности», «экспорт из Российской Федерации и импорт в Российскую Федерацию осуществляется без количественных ограничений».

Исходя из национальных интересов, могут вводиться меры, не носящие экономического характера и затрагивающие внешнюю торговлю товарами, если эти меры:

- необходимы для обеспечения обороны страны и национальной безопасности Российской Федерации;

• необходимы для приобретения или распределения товаров при общем или местном их дефиците;

- необходимы для обеспечения соблюдения не противоречащих международным договорам Российской Федерации нормативных правовых актов Российской Федерации;

• необходимы для соблюдения общественной морали и правопорядка;

• необходимы для охраны жизни и здоровья людей, охраны животного и растительного мира и окружающей среды в целом;

• относятся к импорту или экспорту золота или серебра;

• применяются для защиты культурных ценностей;

• необходимы для предотвращения исчерпания невосполнимых природных ресурсов и проводятся одновременно с ограничениями внутреннего производства и потребления, связанных с использованием невосполнимых природных ресурсов;

• обеспечивают национальную безопасность Российской Федерации;

- защищают внешнее финансовое положение и поддерживают 
платежный баланс Российской Федерации;

- необходимы для выполнения международных обязательств Российской Федерации.

Меры прямого ограничения экспорта (импорта), а также другие защитные меры вводятся в соответствии с общепризнанными нормами международного права. Согласно российскому законодательству их введение предусматривает следующие обязательные действия:

1)обязательно проводится расследование всех обстоятельств, связанных с введением защитных мер. Расследованием занимается специальная комиссия при Правительстве РФ с привлечением необходимых организаций и специалистов.

Расследование может быть начато на основании поручения Правительства и (или) заявления органа исполнительной власти субъекта РФ, и (или) заявления производителя или объединения производителей, чье совокупное производство подобных товаров или товаров, непосредственно конкурирующих с импортируемыми, составляет более $50 \%$ общего внутреннего производства таких товаров. Расследование проводится в течение не более двух месяцев со дня принятия заявления. О начале такого расследования уведомляется соответствующий орган иностранного государства или орган таможенной территории с указанием товара, доказательств наличия ущерба или угрозы его причинения, конкретной предлагаемой защитной меры, срока ее введения, а также готовности провести консультации по этим вопросам;

2)по результатам проведенного расследования составляется доклад федерального органа исполнительной власти, ответственного за координацию внешнеэкономической деятельности. Процедура введения защитных мер гласная с официальным опубликованием в правительственном издании решения правительства о введении защитной меры. Решения правительства принимаются и публикуются не позднее чем за три месяца до введения такого рода ограничений с указанием общего количества и стоимости 
товаров, подпадающих под ограничение.

Срок действия защитной меры, ее досрочная отмена или продление, а также все изменения устанавливаются Правительством Российской Федерации с учетом международных обязательств Российской Федерации.

Распределение квот и выдача лицензий при установлении количественных ограничений осуществляются путем проведения конкурсов или аукционов. Порядок проведения конкурса или аукциона устанавливается Правительством РФ. Не допускаются ограничения числа участников такого конкурса или аукциона и их дискриминация по признакам форм собственности, места регистрации, положения на рынке.

В качестве государственного регулирования внешнеторговой деятельности могут также применяться и другие меры, такие, как наблюдение за экспортом или импортом отдельных видов товаров, предоставление исключительного права на экспорт или импорт отдельных видов товаров, вводиться специальные защитные меры, антидемпинговые меры и компенсационные меры.

В целях защиты прав и интересов потребителей, противодействия недобросовестной практике искажения сведений об импортируемых в Российскую Федерацию товарах, в том числе занижения их стоимости, Правительство Российской Федерации вправе вводить предотгрузочную инспекцию, включая выдачу сертификата о прохождении предотгрузочной инспекции, в отношении отдельных видов товаров, импортируемых в Российскую Федерацию. Предотгрузочная инспекция вводится в отношении отдельных товаров на срок, не превышающий три года. Перечни товаров, в отношении которых вводится предотгрузочная инспекция, утверждаются Правительством Российской Федерации.

Среди мер нетарифного регулирования ВЭД можно выделить категорию мер, связанных с выполнением таможенных или административных формальностей. Одной из разновидностей таких мер, направленных на ограничение ввоза, являются импортные налоги и депозиты.

К числу импортных налогов (не следует их смешивать с импортными 
пошлинами) относятся:

- пограничный налог, которым облагаются товары за факт пересечения границы;

- сборы, связанные с оформлением документов на таможне, таможенным досмотром товара, проверкой его качества;

- другие сборы (портовые, статистические, фитосанитарные и т.д.).

Особую разновидность импортного налога представляют скользящие импортные сборы, широко применяемые в ЕС в качестве протекционистской меры в аграрном секторе. По характеру действия скользящие импортные сборы близки к таможенным пошлинам, но в отличие от них их уровень постоянно меняется в зависимости от соотношения внутренних и мировых цен на сельскохозяйственную продукцию.

Одна из разновидностей административных и таможенных формальностей - сертификация ввозимых товаров и услуг. Ввозимые на территорию Российской Федерации товары должны соответствовать техническим, фармакологическим, санитарным, ветеринарным и экологическим стандартам (регламентам) и требованиям, установленным в РФ. Запрещается ввоз товаров, которые не соответствуют указанным выше стандартам (регламентам) и требованиям, не имеют сертификата, маркировки или знака соответствия в предусмотренных законодательством случаях, запрещены к использованию как опасные потребительские товары, имеют дефекты, представляющие опасность для потребителей. Порядок сертификации ввозимых товаров регулируется законом РФ «О сертификации продукции и услуг» и иными правовыми актами.

Российское законодательство государственного регулирования ВЭД

Наибольшее место в правовом регулировании внешнеэкономической сферы отводится национальному (внутреннему) законодательству, включающему общие нормы и специальное законодательство.

Общее аконодательство представлено правовыми нормами, регламентирующими основные принципы функционирования государства и 
различных сфер жизнедеятельности, в том числе внешнеэкономической. К общему законодательству относятся Конституция РФ, Гражданский кодекс РФ, Налоговый кодекс РФ, Гражданский процессуальный кодекс РФ, Арбитражный процессуальный кодекс РФ и т.п.

В Конституции РФ сформулированы нормы о приоритете международных договоров (ст. 15), о праве выезда за границу (ст. 27) и праве занятия любой не запрещенной законом экономической деятельностью, о статусе иностранцев (ст. 62), о компетенции субъектов РФ (ст. 71-73, 76, 78) и др.

Гражданский кодекс РФ устанавливает правила гражданского законодательства, применяемые к отношениям с участием иностранных граждан и иностранных юридических лиц (п. 1 ст. 2), правило о недействительности внешнеэкономической сделки при несоблюдении письменной формы (п. 3 ст. 162), отсылочные нормы использования иностранной валюты, сферы и правила применения норм международного частного права (раздел 3) и др.

Правила Налогового кодекса РФ охватывают деятельность таможенных органов (ст. 9), а также иностранных физических и юридических лиц (ст. 11), порядок налогообложения и взимания различных видов налогов и сборов (часть вторая НК РФ).

Процессуальное законодательство регламентирует правила производства по делам с участием иностранных юридических лиц в судах общей юрисдикции (ст. 433-438 Гражданского процессуального кодекса РФ) и арбитражных судах (ст. 210-215 Арбитражного процессуального кодекса РФ). Закон РФ от 7 июля 1993 г. № 5338-1 «О международном коммерческом арбитраже» регламентирует деятельность третейских судов при рассмотрении споров в сфере ВЭД.

В то же время Конституцией РФ и Гражданским кодексом РФ предусмотрена возможность специального регулирования внешнеэкономической сферы, что происходит посредством специального законодательства, которое можно разделить по определенным направлениям. 
Приведем основополагающие нормативные правовые акты по направлениям регулирования:

1) государственное регулирование внешнеторговой деятельности:

- Федеральный закон «Об основах государственного регулирования внешнеторговой деятельности» от 8 декабря 2003 г. № 164-Ф3 (ред. от 2 февраля 2006 г.);

- Федеральный закон «О специальных защитных, антидемпинговых и компенсационных мерах при импорте товаров» от 8 декабря 2003 г. № $165-\Phi 3$ (ред. от 30 декабря 2006 г.)

- Федеральный закон «О мерах по защите коммерческих интересов Российской Федерации при осуществлении внешней торговли товарами от 14 апреля 1998 г. № 63-Ф3 (ред. от 8 декабря 2003 г., с изм. и доп.);

- Таможенный кодекс РФ (утв. Федеральным законом от 28 мая 2003 г. № 61-Ф3 (ред. от 30 декабря 2006 г.);

- Закон РФ «О таможенном тарифе» от 21 мая 1993 г. № 5003-1 (ред. от 10 ноября 2006 г.);

- Федеральный закон «О техническом регулировании» от 27 декабря 2002 г. № 184-Ф3 (ред. от 9 мая 2005 г.);

- Кодекс торгового мореплавания РФ от 30 апреля 1999 г. № 81-ФЗ (ред. от 4 декабря 2006 г.);

- Воздушный кодекс РФ от 19 марта 1997 г. № 60-Ф3 (ред. от 30 декабря 2006 г.);

- Устав железнодорожного транспорта РФ (Федеральный закон от 10 января 2003 г. № 18-Ф3, ред. 4 декабря 2006 г.);

- Федеральный закон «О лицензировании отдельных видов деятельности» от 8 августа 2001 г. № 128-Ф3 (ред. от 5 февраля 2007 г.);

- Постановление Правительства РФ «О порядке проведения конкурсов и аукционов по продаже квот при введении количественных ограничений и лицензирования экспорта и импорта товаров (работ, услуг) в Российской Федерации» от 31 декабря 1996 г. (ред. от 9 июня 2005 г.); 
2) валютное регулирование и валютный контроль:

- Федеральный закон «О валютном регулировании и валютном контроле» от 10 декабря 2003 г. № 173-Ф3 (ред. от 30 декабря 2006 г.);

3) регулирование международного кредитования:

- Федеральный закон «О валютном регулировании и валютном контроле» от 10 декабря 2003 г. № 173-Ф3 (ред. от 30 декабря 2006 г.);

- Федеральный закон «О Центральном банке Российской Федерации (Банке России)» от 10 июля 2002 г. № 86-ФЗ (ред. от 29 декабря 2006 г.);

4) регулирование инвестициионной деятельности с участием иностранных инвесторов:

- Федеральный закон «Об инвестиционной деятельности в Российской Федерации, осуществляемой в форме капитальных вложений» от 25 февраля 1999 г. № 39-Ф3 (ред. от 18 декабря 2006 г.);

- Федеральный закон «Об иностранных инвестициях в Российской Федерации» от 9 июля 1999 г. № 160-Ф3 (ред. от 3 июня 2006 г.);

- Федеральный закон «О финансовой аренде (лизинге)» от 29 октября 1998 г. № 164-Ф3 (ред. от 26 июля 2006 г.);

- Федеральный закон «О соглашениях о разделе продукции» от 30 декабря 1995 г. № 225-Ф3 (ред. от 29 декабря 2004 г.);

5) регулирование международного научно-технического сотрудничества:

- Федеральный закон «О науке и государственной научно-технической политике» от 23 августа 1996 г. № 127-Ф3 (ред. от 4 декабря 2006 г.);

- Патентный закон Российской Федерации от 23 сентября 1992 г.№ 3517-1 (ред. от 2 февраля 2006 г.).

\section{2.Регулирование внешнеэкономической деятельности}

\subsection{1. Международное регулирование ВЭД}

Международное регулирование ВЭД обеспечивается посредством международных актов и обычаев.

Международные акты, включенные в систему правового регулирования 
внешнеэкономической сферы конкретного государства, подразделяются на международные договоры и акты международных организаций.

В соответствии с ч. 4 ст. 15 Конституции РФ международные договоры являются составной частью ее правовой системы. Классификация международных договоров осуществляется по нескольким критериям:

1) по количеству участников:

- двусторонние;

- многосторонние.

Двусторонние договоры имеют приоритет для всех субъектов этих договоров. Наиболее распространены в международной практике договоры о взаимной защите инвестиций и об избежании двойного налогообложения.

В качестве примеров многостороннего международного договора можно привести Соглашение о партнерстве и сотрудничестве между Российской Федерацией и Европейским союзом, подписанное в 1994 г. и вступившее в силу в 1997 г., кодексы и конвенции;

2) по охвату:

- региональные;

- универсальные.

Региональные международные договоры, например заключенные в рамках СНГ, имеют приоритет перед универсальными;

3) от имени кого заключень:

- межгосударственные - от имени Российской Федерации, подписываются Президентом страны;

- межправительственные - от имени Правительства РФ (например, межправительственные торгово-экономические и платежные соглашения);

- $\quad$ межведомственные - от имени органов исполнительной власти.

Международные договоры вступают в силу и применяются только после их ратификации и официального опубликования.

По своей структуре международные договоры отражают условия, которые страны-партнеры предоставляют друг другу на взаимной основе и 
которые определяют правовые особенности их взаимоотношений во внешнеэкономической сфере. Важнейшими условиями международных договоров выступают:

1)фиксация режима взаимоотношений: режима наибольшего благоприятствования, национального или преференциального режима;

2)платежные условия определяют технологию расчетов за взаимопоставляемые товары и услуги;

3)транспортные условия - условия транспортного обеспечения взаимного товарооборота;

4)статус торгового представительства в стране-партнере, предусматривающий его экстерриториальность, возможность использования шифровальной связи, дипломатической почты и др.;

5)срок действия и условия денонсации (уведомления о расторжении) международного договора.

Другая составляющая международного права, включенного в правовую систему государства, - акты международных организаций, членом которых оно является. По своей юридической природе акты международных организаций делятся на прямые, обязательные для выполнения странами-участницами, к которым, в частности, относятся нормы Всемирной торговой организации (ВТО), и рекомендательные (модельные), например Венская конвенция о международных договорах купли-продажи товаров 1980 г.

Составляющей правовой системы государства, носящей диспозитивный характер, являются обычаи, которые включают в себя международные торговые обычаи и проформы коммерческих договоров (типовые договоры).

Обычаи образуют так называемое транснациональное экономическое и торговое право. Согласно п. 1 ст. 5 Гражданского кодекса РФ (ГК РФ), сложившееся и широко применяемое в какой-либо области предпринимательской деятельности правило поведения, не предусмотренное законодательством, независимо от того, зафиксировано оно в каком-либо документе, признается обычаем делового оборота. 
В качестве примеров деловых обычаев можно указать Международный свод толкования условий торговли ИНКОТЕРМС-2000 (публикация Международной торговой палаты № 560), Принципы международных коммерческих договоров Международного института по унификации частного права (УНИДРУА, 1994 г.) и др.

\subsection{2. Таможенное регулирование ВЭД}

Под таможенным регулированием внешнеторговой деятельности следует понимать деятельность государственных органов, осуществляющих таможенную политику Российской Федерации и соответствующее регулирование общественных отношений, связанных с порядком перемещения через таможенную границу Российской Федерации товаров и транспортных средств, проведением таможенного контроля, обеспечения выполнения таможенных формальностей и взыскания таможенных платежей при экспортно-импортных операциях, а также соответствующее реагирование при нарушении установленных законодательством правил поведения, регулирующих эти правоотношения.

С целью регулирования столь емких и специфических общественных отношений в Российской Федерации сформировано обособленное таможенное законодательство, объединяющее способы и методы таможенного регулирования.

Основным нормативным документом, регламентирующим порядок таможенного оформления товаров и уплаты таможенных платежей, является Таможенный кодекс РФ.

Отметим, что, согласно Таможенного кодекса РФ, под товарами понимается любое перемещаемое через таможенную границу движимое имущество, а также перемещаемые через таможенную границу отнесенные к недвижимым вещам транспортные средства (кроме транспортных средств, используемых в международных перевозках). Поэтому, говоря о таможенном регулировании, под товарами следует подразумевать не только ценности, приобретаемые для перепродажи (которые классифицируются как товары в 
бухгалтерском учете), но и прочие ввозимые организацией материальные объекты - например, сырье и материалы, приобретаемые для последующего производства продукции, а также основные средства (оборудование, автомобили и прочие объекты).

В соответствии Таможенным кодексом РФ ввоз товаров на территорию Российской Федерации с целью их использования в производственной деятельности или перепродажи на территории России - иными словами, если ввезенные товары остаются на таможенной территории России без обязательства об их вывозе с этой территории - осуществляется в таможенном режиме выпуска для внутреннего потребления. При этом согласно Таможенного кодекса РФ товары приобретают для таможенных целей статус находящихся в свободном обращении на таможенной территории РФ после уплаты таможенных пошлин, налогов и соблюдения всех ограничений, установленных в соответствии с законодательством РФ о государственном регулировании внешнеторговой деятельности. При несоблюдении данных условий товары подлежат условному выпуску.

В соответствии со статьей 165 Таможенного кодекса РФ экспорт представляет собой таможенный режим, при котором товары, находящиеся в свободном обращении на таможенной территории РФ, вывозятся с этой территории без обязательства об обратном ввозе.

Согласно статье 166 Таможенного кодекса РФ экспорт товаров осуществляется при условии:

- уплаты вывозных таможенных пошлин в порядке, предусмотренном данным Кодексом,

- соблюдения ограничений, установленных в соответствии с законодательством РФ о государственном регулировании внешнеторговой деятельности,

- и выполнения иных требований и условий, установленных данным Кодексом, другими федеральными законами и иными правовыми актами РФ. 
Таможенное оформление импортируемых и экспортируемых товаров

При прибытии товаров и транспортных средств на таможенную территорию Российской Федерации в соответствии с Таможенным кодексом РФ перевозчик обязан представить таможенному органу соответствующие документы и сведения в зависимости от вида транспорта, на котором осуществляется международная перевозка. После этого товары могут быть разгружены или перегружены, помещены на склад временного хранения, заявлены к определенному таможенному режиму либо к внутреннему таможенному транзиту. С момента предъявления товаров в месте их прибытия такие товары приобретают статус находящихся на временном хранении.

В соответствии с Таможенным кодексом РФ при перемещении товаров через таможенную границу они подлежат декларированию таможенным органам. Декларирование товаров в соответствии с Таможенным кодексом РФ может производиться путем заявления в таможенной декларации самим декларантом либо таможенным брокером (представителем), причем перечень сведений, подлежащих указанию в таможенной декларации, ограничивается только теми сведениями, которые необходимы для целей исчисления и взимания таможенных платежей, формирования таможенной статистики и применения таможенного законодательства РФ. В частности, в таможенной декларации могут быть указаны следующие основные сведения (в том числе в кодированном виде):

1) заявляемый таможенный режим;

2) сведения о декларанте, таможенном брокере (представителе), об отправителе и о получателе товаров;

3) сведения о транспортных средствах, используемых для международной перевозки товаров;

4) сведения о товарах:

- наименование;

- описание;

- классификационный код товаров по Товарной номенклатуре 
внешнеэкономической деятельности (ТН ВЭД);

- наименование страны происхождения;

- наименование страны отправления (назначения);

- описание упаковок (количество, вид, маркировка и порядковые номера);

- количество в килограммах (вес брутто и вес нетто) или в других единицах измерения; таможенная стоимость;

5) сведения об исчислении таможенных платежей:

- ставки вывозных таможенных пошлин, налогов, таможенных сборов;

- применение льгот по уплате таможенных пошлин, налогов, таможенных сборов;

- применение тарифных преференций;

- суммы исчисленных таможенных пошлин, налогов, таможенных сборов;

- установленный Центральным банком РФ на день подачи таможенной декларации курс валюты для целей учета и таможенных платежей;

6) сведения о внешнеэкономической сделке и ее основных условиях;

7) сведения о соблюдении ограничений, установленных в соответствии с законодательством РФ о государственном регулировании внешнеторговой деятельности;

8) сведения о производителе товаров;

9) сведения, подтверждающие соблюдение условий помещения товаров под заявляемый таможенный режим;

10) сведения о представляемых документах, необходимых для декларирования;

11) сведения о лице, составившем таможенную декларацию;

12) место и дата составления таможенной декларации.

Таможенная декларация подписывается сотрудником организации, составившей данную декларацию, и удостоверяется печатью. Форма таможенной декларации устанавливается Федеральной таможенной службой (ФТС РФ). 
Помимо самой таможенной декларации в таможенные органы необходимо представить также и документы, подтверждающие заявленные в таможенной декларации сведения, по перечню, установленному в статье 131 Таможенного кодекса РФ, а именно:

- договоры международной купли-продажи или другие виды договоров, заключенных при совершении внешнеэкономической сделки, а в случае совершения односторонних внешнеэкономических сделок - иные документы, выражающие содержание таких сделок;

- имеющиеся в распоряжении декларанта коммерческие документы;

- транспортные (перевозочные) документы;

- разрешения, лицензии, сертификаты и (или) иные документы, подтверждающие соблюдение ограничений, установленных в соответствии с законодательством РФ о государственном регулировании внешнеторговой деятельности;

- документы, подтверждающие происхождение товаров (в случаях, предусмотренных статьей 37 Кодекса);

- платежные и расчетные документы;

- документы, подтверждающие сведения о декларанте;

- а также документы, подтверждающие право декларанта на получение льгот по уплате таможенных платежей, на неприменение к товарам запретов и ограничений, установленных в соответствии с законодательством РФ либо на уменьшение налоговой базы.

Согласно пункту 1 статьи 129 Таможенного кодекса РФ таможенная декларация на товары, ввозимые на таможенную территорию Российской Федерации, подается не позднее 15 дней со дня предъявления товаров таможенным органам в месте их прибытия на таможенную территорию Российской Федерации или со дня завершения внутреннего таможенного транзита, если декларирование товаров производится не в месте их прибытия. Если этот срок недостаточен для сбора необходимых документов и сведений, по мотивированному обращению этого декларанта в письменной форме 
таможенный орган продлевает срок подачи таможенной декларации, однако продление срока подачи таможенной декларации не должно приводить к нарушению срока временного хранения товаров.

Факт подачи таможенной декларации и представления необходимых документов фиксируется в день их получения таможенным органом.

Согласно статье 60 Таможенного кодекса РФ при вывозе товаров из РФ таможенное оформление данных товаров начинается в момент представления таможенной декларации (а в отдельных случаях, предусмотренных данным Кодексом, - устного заявления либо совершения иных действий, свидетельствующих о намерении лица осуществить таможенное оформление) и завершается совершением таможенных операций, необходимых в соответствии с Таможенным кодексом РФ для помещения товаров под таможенный режим экспорта, а также для исчисления и взимания таможенных платежей.

Согласно Таможенного кодекса РФ таможенная декларация на товары, вывозимые с таможенной территории РФ, подается до их убытия с таможенной территории РФ. Факт подачи таможенной декларации и представления необходимых документов фиксируется в день их получения таможенным органом, причем, по запросу лица, подавшего таможенную декларацию, таможенный орган обязан незамедлительно выдать письменное подтверждение о получении таможенной декларации и представлении необходимых документов (в том числе и в форме электронного документа).

В соответствии со статьей 137 Таможенного кодекса РФ при вывозе российских товаров с таможенной территории РФ по желанию декларанта может применяться упрощенный порядок декларирования:

- подача неполной таможенной декларации в соответствии со статьей 135 Таможенного кодекса РФ (если декларант по независящим от него причинам не располагает всей необходимой для заполнения таможенной декларации информацией);

- подача периодической таможенной декларации согласно статье 136 Таможенного кодекса РФ (при регулярном перемещении через таможенную 
границу товаров одним и тем же лицом таможенный орган);

- периодическое временное декларирование в соответствии со статьей 138 Таможенного кодекса РФ.

Упрощенный порядок декларирования российских товаров применяется, если это не препятствует осуществлению таможенного контроля и не освобождает декларанта от соблюдения требований и условий, установленных Таможенным кодексом и иными правовыми актами РФ, в части полноты и своевременности уплаты таможенных платежей, соблюдения запретов и ограничений, установленных в соответствии с законодательством РФ о государственном регулировании внешнеторговой деятельности, а также соблюдения таможенных режимов. При отказе таможенного органа в применении упрощенного порядка декларирования российских товаров таможенный орган уведомляет об этом декларанта с указанием условий, выполнение которых необходимо для применения такого порядка.

В частности, согласно Таможенного кодекса РФ при вывозе с таможенной территории РФ российских товаров, в отношении которых не могут быть представлены точные сведения, необходимые для таможенного оформления, в соответствии с обычным ведением внешней торговли, допускается их периодическое временное декларирование путем подачи временной таможенной декларации. Однако после убытия российских товаров с таможенной территории РФ декларант обязан подать полную и надлежащим образом заполненную таможенную декларацию на все российские товары, вывезенные в определенный период времени. Подача полной и надлежащим образом заполненной таможенной декларации осуществляется в срок, устанавливаемый таможенным органом по заявлению декларанта, с учетом срока, необходимого декларанту для получения сведений, достаточных для подачи полной и надлежащим образом заполненной таможенной декларации, но не более 90 дней со дня, следующего за днем истечения периода времени для вывоза декларируемых товаров.

Период времени, в течение которого предполагается вывозить российские 
товары, декларируемые с использованием временной таможенной декларации, определяется декларантом, однако при этом необходимо учитывать, что в отношении российских товаров, которые облагаются вывозными таможенными пошлинами или к которым применяются запреты и ограничения, установленные в соответствии с законодательством РФ о государственном регулировании внешнеторговой деятельности, этот период не может превышать один календарный месяц, а временная таможенная декларация принимается таможенным органом не ранее чем за 15 дней до начала этого периода.

Во временной таможенной декларации допускается заявление сведений исходя из намерений о вывозе ориентировочного количества российских товаров в течение определенного периода времени, условной таможенной стоимости (оценки), определяемой согласно планируемому к перемещению через таможенную границу количеству российских товаров, а также исходя из предусмотренных условиями внешнеэкономической сделки потребительских свойств российских товаров и порядка определения их цены на день подачи временной таможенной декларации. Убытие российских товаров с таможенной территории РФ в количестве, превышающем заявленное во временной таможенной декларации, не допускается, за исключением случаев, установленных пунктами 1 и 2 статьи 122 Таможенного кодекса РФ.

При использовании временной таможенной декларации запреты и ограничения экономического характера, установленные в соответствии с законодательством Российской Федерации о государственном регулировании внешнеторговой деятельности, применяются на день принятия таможенным органом этой декларации.

Ставки вывозных таможенных пошлин также применяются на день принятия таможенным органом временной таможенной декларации. Вывозные таможенные пошлины уплачиваются одновременно с подачей временной таможенной декларации в таможенный орган. Если сумма подлежащих уплате вывозных таможенных пошлин увеличивается в результате уточнения сведений, доплата суммы вывозных таможенных пошлин осуществляется 
одновременно с подачей полной и надлежащим образом заполненной таможенной декларации. Пени в указанном случае не начисляются. Возврат излишне уплаченных или излишне взысканных сумм вывозных таможенных пошлин осуществляется в соответствии со статьей 355 Таможенного кодекса РФ, Особенности уплаты вывозных таможенных пошлин при вывозе товаров трубопроводным транспортом и по линиям электропередачи определяются статьями 312 и 314 Таможенного кодекса РФ.

Если по истечении четырех месяцев со дня принятия временной таможенной декларации российские товары не будут вывезены с таможенной территории РФ, таможенная декларация, в которой такие товары были заявлены к вывозу, считается неподанной. По мотивированному запросу заинтересованного лица таможенный орган продлевает указанный срок, но не более чем еще на четыре месяца.

\section{Определение, заявление и контроль таможенной стоимости товаров}

Таможенная стоимость ввозимых товаров служит налоговой базой для расчета:

— таможенной пошлины по адвалорной ставке;

-НДС и акциза, взимаемых при ввозе товаров на таможенную территорию РФ;

—для исчисления таможенных пошлин, налогов, подлежащих уплате физическими лицами по единым ставкам;

—для определения сбора за таможенное оформление товаров.

Таможенная стоимость вывозимых товаров служит налоговой базой для расчета экспортной таможенной пошлины по адвалорной ставке.

Элементы, входящие в структуру таможенной стоимости, могут быть различны, в зависимости от того, стоимость это ввозимых или вывозимых товаров.

Кроме того, необходимость определения таможенной стоимости может возникнуть:

- при изменении таможенного режима; 
- в случае уплаты таможенных платежей в отношении незаконно перемещенных товаров или товаров, использованных на территории РФ в нарушение требований таможенных процедур.

В соответствии со статьей 19 Закона РФ «О таможенном тарифе» таможенной стоимостью ввозимого на таможенную территорию РФ товара является стоимость сделки, фактически уплаченная или подлежащая уплате за товары при их продаже на экспорт в РФ и дополненная в соответствии со статьей 19.1 вышеупомянутого закона.

Общая структура таможенной стоимости включает в себя цену сделки, уплаченную или подлежащую уплате при пересечении товаром таможенной границы РФ (до порта или иного места ввоза), а также расходы, понесенные дополнительно в связи с перемещением, производством или продажей ввозимого товара.

Основными элементами таможенной стоимости являются:

1) цена товара, согласованная при заключении внешнеторгового контракта;

2) расходы по доставке товара до места ввоза на таможенную территорию РФ (в т.ч. стоимость транспортировки, погрузки, выгрузки или перегрузки товара, затраты на страхование);

3) расходы, понесенные покупателем при осуществлении внешнеэкономической сделки (комиссионные и брокерские вознаграждения, за исключением комиссионных по закупке товара; стоимость многооборотной тары, если она рассматривается как единое целое с товаром в соответствии с ТН ВЭД, расходы на упаковку);

4) стоимость услуг или товаров, предоставленных покупателем продавцу для производства или продажи ввозимых товаров (сырье, материалы, комплектующие; инструменты, штампы и т. п. предметы, используемые при изготовлении оцениваемых изделий смазочные материалы, топливо и пр.; стоимость ин- 
женерной проработки, чертежей, эскизов и др. работ, выполненных вне территории РФ);

5) лицензионные и иные платежи за использование объектов интеллектуальной собственности;

6) доход продавца от любых последующих перепродаж или использования товара на территории РФ, который должен быть выплачен покупателем продавцу.

Перечисленные в П.П. со 2) по 6) статьи расходов должны быть дополнительно включены в структуру ТС в том случае, если они не были учтены ранее.

Из цены сделки могут быть вычтены затраты, понесенные на территории РФ в связи с оказанием технической помощи, монтажом, сборкой, наладкой ввезенных товаров, транспортировкой их от места ввоза до места назначения, в том случае, когда они оговорены в контракте и выделены в инвойсе отдельной строкой, а также ввозные таможенные пошлины, налоги и сборы, подлежащие уплате в РФ в связи с ввозом или реализацией товаров (при условиях поставки DDP).

При наличии скидки, предоставленной на момент совершения внешнеторговой сделки, условия ее определения и подтверждения должны быть оговорены в контракте. Величина скидки должна быть выделена отдельной строкой в счете-фактуре, выставленном продавцом.

В соответствии с п.п. 1, 2 ст. 323 ТК РФ таможенная стоимость товаров определяется декларантом согласно методам определения таможенной стоимости, установленным законодательством РФ, и заявляется в таможенный орган при декларировании товаров.

Методы определения таможенной стоимости товаров, ввозимых на таможенную территорию РФ, последовательность и порядок их применения установлены Законом РФ «О таможенном тарифе».

В соответствии с этим законом определение таможенной стоимости товаров, ввозимых на таможенную территорию РФ, производится путем 
применения следующих методов:

-по стоимости сделки с ввозимыми товарами;

—по стоимости сделки с идентичными товарами;

—по стоимости сделки с однородными товарами;

—вычитания стоимости;

- сложения стоимости;

- резервного метода.

Основным методом определения таможенной стоимости товаров является метод по стоимости сделки с ввозимыми товарами (метод 1).

В случае невозможности использования первого метода определения таможенной стоимости последовательно применяются оценочные методы. Каждый последующий метод применяется, если таможенную стоимость невозможно определить с помощью предыдущего метода. Методы вычитания и сложения стоимости (между собой) могут применяться в любой последовательности.

При использовании метода 2 по стоимости сделки с идентичными товарами за основу при определении таможенной стоимости принимается стоимость идентичных товаров, имеющих одинаковые с оцениваемыми товарами физические характеристики, качество и репутацию на рынке, страну происхождения, фирму - производитель, при условии их продажи и ввоза не ранее чем за 90 дней до ввоза оцениваемых товаров.

При определении таможенной стоимости с помощью метода 3 по стоимости сделки с однородными товарами за основу принимается стоимость однородных товаров, имеющих схожие с оцениваемыми признаки по качеству, репутации на рынке, стране происхождения и производителю. В случае отсутствия сведений о товарах, произведенных тем же лицом, что и ввозимые, допускается использование данных по товарам, изготовленным иным производителем, при совпадении остальных характеристик. (Пример: телевизионные приемники «Sony» и «Panasonic», имеющие идентичные технические параметры, в т.ч. мощность, размеры, исходные материалы для 
производства).

При расчете таможенной стоимости методом 4 на основе вычитания используются сведения о стоимости ввезенных идентичных или однородных товаров, проданных на территории РФ не позднее 90 дней с даты ввоза оцениваемых товаров, лицу, не являющемуся взаимозависимым с участником сделки, с учетом разрешенных вычетов, понесенных на территории РФ, в том числе: комиссионные вознаграждения, обычные торговые надбавки на прибыль и общие расходы в связи с продажей на внутреннем рынке, обычные расходы на транспортировку, погрузо-разгрузочные работы, страхование на территории РФ, а также суммы таможенных платежей и прочих налогов, подлежащих уплате в связи с ввозом и продажей товаров в РФ. При определении таможенной стоимости методом 5 на основе сложения используются данные о стоимости материалов и издержек, понесенных изготовителем при производстве товара, с учетом общих затрат и прибыли экспортера, которые возникают в связи с поставкой товара в РФ. Метод 6 (резервный) используется, когда таможенная стоимость не может быть определена ни одним из перечисленных методов, на основе информации, полученной с учетом мировой практики. При применении резервного метода таможенный орган предоставляет декларанту имеющуюся в его распоряжении ценовую информацию.

При определении таможенной стоимости резервным методом не может использоваться:

— цена товара на внутреннем рынке без вычета данных, указанных в статье 22 Закона РФ «О таможенном тарифе»;

— цена на товары российского происхождения;

- цена товара, поставленного из страны вывоза в третьи страны;

— произвольно установленная и достоверно не подтвержденная цена.

Для всех оценочных методов в случае выявления нескольких сделок с товарами, идентичными или однородными ввезенным, за основу принимается наименьшая из стоимостей, скорректированная с учетом дополнительных 
расходов, имеющих отношение к цене внешнеэкономической сделки, на основании документально подтвержденной информации.

Основными условиями применения метода 1 по стоимости сделки с ввозимыми товарами являются:

— наличие сделки купли-продажи, носящей международный характер, при возможности определить или рассчитать цену сделки на основании контракта и выставленного продавцом счета-фактуры;

— отсутствие ограничений прав покупателя на пользование товаром;

- отсутствие условий, влияние которых на стоимость сделки невозможно учесть;

- документальное подтверждение сведений, обосновывающих заявляемую таможенную стоимость товара;

— отсутствие влияния на цену сделки взаимозависимости, имеющейся между участниками внешнеторговой сделки.

Таможенная стоимость вывозимых товаров согласно п. 2 ст. 17 закона РФ "О таможенном тарифе" определяется Правительством РФ. Основными принципами определения таможенной стоимости вывозимых товаров являются те же принципы, которые установлены Законом для определения таможенной стоимости товаров, ввозимых на таможенную территорию РФ, с учетом некоторых особенностей. Так, в соответствии с Правилами определения таможенной стоимости товаров, вывозимых с таможенной территории Российской Федерации, утвержденных постановлением Правительства РФ от 13 августа 2006 г. N 500 “О порядке определения таможенной стоимости товаров, перемещаемых через таможенную границу Российской Федерации”, таможенная стоимость товаров определяется по стоимости сделки с ними, т.е. цене, фактически уплаченной или подлежащей уплате при продаже товаров на экспорт и дополненной в соответствии с Правилами, при условии, что:

- не существует прямо или косвенно установленных продавцом ограничений в отношении прав покупателя на пользование и распоряжение товарами, за исключением тех, что ограничивают географический регион, в 
котором товары могут быть перепроданы, или существенно не влияют на стоимость товаров;

- продажа товаров или их цена не зависит от соблюдения условий или обязательств, влияние которых на стоимость товаров не может быть количественно определено;

- любая часть дохода, полученного в результате последующей продажи товаров, распоряжения товарами иным способом или их использования, не будет причитаться прямо или косвенно продавцу, за исключением случаев, когда могут быть произведены дополнительные начисления;

- покупатель и продавец не являются взаимосвязанными лицами или покупатель и продавец являются взаимосвязанными лицами, но стоимость сделки с вывозимыми товарами приемлема для таможенных целей.

Ценой, фактически уплаченной или подлежащей уплате за вывозимые товары, является общая сумма всех платежей, осуществленных или подлежащих осуществлению покупателем непосредственно продавцу и (или) третьему лицу в пользу продавца за вывозимые товары.

В таможенную стоимость вывозимых товаров не включаются следующие расходы при условии, что они выделены из цены, фактически уплаченной или подлежащей уплате, заявлены декларантом и подтверждены им документально:

- расходы по перевозке (транспортировке) товаров, осуществляемой для их вывоза с таможенной территории РФ, и расходы по последующей перевозке (транспортировке);

- пошлины, налоги и сборы, взимаемые в РФ в связи с вывозом товаров;

- пошлины, налоги и сборы, взимаемые в отношении оцениваемых товаров в стране, в которую ввозятся эти товары.

При определении таможенной стоимости вывозимых товаров по стоимости сделки с этими товарами к цене, фактически уплаченной или подлежащей уплате, должны быть дополнительно начислены расходы, связанные с приобретением товара, в размере, не включенном в указанную цену. 
Если таможенная стоимость вывозимых товаров не может быть определена по стоимости сделки с ними, то используются методы:

- по стоимости сделки с идентичными товарами;

- по стоимости сделки с однородными товарами;

- резервный метод.

Если в таможенные органы подлежит заявлению таможенная стоимость российских товаров, в отношении которых не могут быть предоставлены точные сведения о таможенной стоимости при вывозе с таможенной территории РФ, допускается их периодическое временное декларирование путем подачи временной таможенной декларации, в которой допускается заявление условной таможенной стоимости вывозимых товаров. Условная таможенная стоимость вывозимых товаров определяется согласно планируемому к перемещению через таможенную границу количеству российских товаров, а также, исходя из предусмотренных условиями внешнеэкономической сделки потребительских свойств российских товаров и порядка определения их цены на день подачи временной таможенной декларации.

Таможенная стоимость заявляется (декларируется) декларантом таможенному органу РФ при таможенном оформлении товаров, перемещаемых через таможенную границу или при изменении таможенного режима.

Заявляемая декларантом таможенная стоимость товаров и представляемые им сведения, относящиеся к ее определению, должны основываться на достоверной и документально подтвержденной информации.

Для подтверждения заявленных сведений по таможенной стоимости декларант должен представить следующие документы:

- учредительные документы лица, перемещающего товары;

- внешнеторговый контракт и дополнительные соглашения к нему;

- платежные и (или) бухгалтерские документы, подтверждающие стоимость товара (счет-фактура, банковские платежные документы); 
- транспортные и страховые документы, если они имеются, в зависимости от условий поставки;

- счет за транспортировку или официально заверенную калькуляцию транспортных расходов в случаях, когда транспортные расходы не были включены в счет-фактуру;

- таможенную декларацию страны отправления (если она имеется);

- упаковочные листы;

- лицензию для товаров, импорт которых осуществляется по лицензиям в соответствии с установленным порядком;

- сертификат о происхождении товара, сертификат качества, безопасности и др.

В качестве дополнительных сведений таможенным органом могут быть затребованы следующие документы: контракты с третьими лицами, имеющие отношение к сделке; счета за платежи третьим лицам в пользу продавца; счета за комиссионные, брокерские услуги, имеющие отношение к сделке с оцениваемым товаром; бухгалтерская документация; лицензионные или авторские соглашения; складские квитанции; каталоги, спецификации, прейскуранты цен (прайс-листы) фирм-изготовителей и др. Перечисленные документы во ВЭД относят к товаросопроводительным документам.

Заявляемая таможенная стоимость товара указывается декларантом в графах 12 и 45 Грузовой таможенной декларации / Транзитной декларации (далее - ГТД) и во многих случаях в декларации таможенной стоимости (далее - ДТС).

Для заявления таможенной стоимости ввозимых товаров применяются формы декларации таможенной стоимости ДТС-1 и ДТС-2.

Форма ДТС-1 предназначена для использования при заявлении таможенной стоимости, определяемой по методу 1.

Форма ДТС-2 предназначена для использования при определении таможенной стоимости по одному из методов 2-6.

Контроль таможенной стоимости товаров осуществляется таможенными 
органами в порядке, определяемом ФТС РФ в соответствии с Таможенным кодексом. Таможенный орган на основании документов и сведений, представленных декларантом, a также на основании имеющейся в его распоряжении информации, используемой при определении таможенной стоимости товаров, принимает решение о согласии с избранным декларантом методом определения таможенной стоимости товаров и о правильности определения заявленной декларантом таможенной стоимости товаров.

Декларация таможенной стоимости (ДТС) является приложением к соответствующей ГТД и без нее недействительна.

ДТС заполняется на все товары, ввозимые на территорию РФ, при заявлении тех таможенных режимов, в соответствии с которыми ввозимые товары облагаются таможенными пошлинами, акцизами и НДС.

ДТС состоит из двух основных листов. На первом листе указываются общие сведения о партии товара (продавец, покупатель, контракт, инвойс и т.д.). На втором листе ДТС указывается код товара, цена сделки и все дополнительные начисления и разрешенные вычеты к цене. Второй лист позволяет заявить таможенную стоимость трех наименований товаров. Если партия состоит из большего количества наименований, то заполняется следующий лист ДТС по форме второго листа, который называется дополнительным. Единовременно к основным листам ДТС можно приложить не более 33 дополнительных листов. Нумерация дополнительных листов начинается с номера 3.

Участники ВЭД должны принимать во внимание, что ДТС заполняется на все товары, ввозимые на территорию Российской Федерации, декларируемые с использованием грузовой таможенной декларации, за исключением случаев:

- ввоза товаров физическими лицами (для личных, семейных, домашних и иных нужд, не связанных с осуществлением предпринимательской деятельности);

- ввоза товаров, заявляемая величина таможенной стоимости которых не 
порождает обязанности уплаты таможенных платежей (например, в соответствии с ТК РФ таможенные пошлины, налоги не уплачиваются, если общая таможенная стоимость товаров, ввозимых на таможенную территорию Российской Федерации в течение одной недели в адрес одного получателя, не превышает 5000 рублей);

- если при таможенном оформлении одной из предыдущих партий товаров, поставленных по внешнеторговому договору, согласно которому ввозятся декларируемые товары, таможенным органом было принято решение о возможности применения метода определения таможенной стоимости по стоимости сделки с ввозимыми товарами в отношении всех товаров, поставляемых по этому договору, и не производятся дополнительные начисления к цене сделки и (или) вычеты из нее, а условия договора остаются неизменными (специальный порядок контроля таможенной стоимости товаров).

За исключением случаев ввоза товаров физическими лицами таможенный орган оставляет за собой право требовать при необходимости письменного в произвольной форме представления ДТС для подтверждения заявленной декларантом в ГТД таможенной стоимости.

Для подтверждения заявленной таможенной стоимости товаров декларант обязан: по требованию таможенного органа представить необходимые дополнительные документы и сведения, либо дать в письменной форме объяснение причин, по которым запрашиваемые таможенным органом документы и сведения не могут быть представлены. Декларант имеет право доказать правомерность использования избранного им метода определения таможенной стоимости товаров и достоверность представленных им сведений.

Таможенный орган вправе затребовать дополнительные документы (например: контракты с третьими лицами, имеющими отношение к сделке, бухгалтерскую документацию, складские квитанции и т.п.) и устанавливает срок для их представления, который должен быть достаточен для этого.

При отсутствии данных, подтверждающих правильность определения 
таможенной стоимости товаров, либо при обнаружении признаков того, что сведения не являются достоверными и (или) достаточными, таможенный орган вправе принять решение о несогласии с использованием избранного метода определения таможенной стоимости товаров и предложить декларанту определить таможенную стоимость товаров с использованием другого метода.

В случаях, когда декларантом не представлены в установленные таможенным органом сроки дополнительные документы и при этом декларант отказался определить таможенную стоимость товаров на основе другого метода по предложению таможенного органа, таможенный орган самостоятельно определяет таможенную стоимость товаров, последовательно применяя методы определения таможенной стоимости товаров. Таможенный орган уведомляет декларанта о принятом решении в письменной форме не позднее дня, следующего за днем принятия такого решения.

В случае наличия $\mathrm{y}$ декларанта документально подтвержденной информации о таможенной стоимости идентичных или однородных ранее ввезенных товаров, либо об их цене на внутреннем рынке, либо калькуляций или прейскурантов изготовителя, которых нет у таможенного органа, производящего оформление товара, возможно ее использование для проверки заявленной таможенной стоимости при условии, что в ее подтверждение предоставлены соответствующие документы.

Корректировка таможенной стоимости (КТС) применяется для уточнения сведений о декларируемых (посредством ГТД) товарах.

В случаях несоответствия заявленной таможенной стоимости действительной может быть произведена корректировка таможенной стоимости, при этом заполняется специальная форма корректировки таможенной стоимости и таможенных платежей на бланках КТС-1 (основной лист) и КТС-2 (добавочный лист).

Корректировка таможенной стоимости может осуществляться в процессе 
производства таможенного оформления и проведения таможенного контроля (например, при выявлении технических ошибок, несоответствия величины таможенной стоимости ее компонентам, необоснованного выбора метода определения таможенной стоимости, несоответствия фактурной и таможенной стоимости товара). В случае временной (условной) оценки товара таможенная стоимость может быть изменена также при представлении декларантом уточняющих сведений о товаре, при наличии у таможенного органа оснований полагать, что документы и сведения, представленные дополнительно, не являются достоверными и в других случаях. После завершения таможенного оформления и выпуска товаров в соответствии с заявленным режимом таможенная стоимость подлежит корректировке при выявлении декларантом или таможенным органом технических или методологических ошибок, повлиявших на величину таможенной стоимости; при установлении дополнительной информации, не известной на момент таможенного оформления и не учтенной ранее. Таможенная стоимость подлежит корректировке и по результатам проверок, осуществляемых налоговыми и правоохранительными органами, если в ходе таких проверок были выявлены дополнительные сведения о товаре, его стоимости и обстоятельствах сделки, которые не были учтены ранее, при расчете суммы подлежащих уплате таможенных платежей.

При корректировке таможенной стоимости обязательным является заполнение формы корректировки таможенной стоимости и таможенных платежей (КТС) на бумажном и электронном носителях.

Форма корректировки таможенной стоимости и таможенных платежей (KTC) является неотъемлемой частью соответствующей грузовой таможенной декларации. КТС-1 и КТС-2 состоит из четырех сброшюрованных листов самокопирующейся бумаги, которые распределяются аналогично листам грузовой таможенной декларации (ГТД). КТС-1 используется для уточнения сведений в отношении одного товара. При уточнении сведений в отношении нескольких товаров, декларируемых в одной ГТД, используются добавочные 
листы КТС-2, каждый из которых дает возможность указывать сведения еще по двум товарам. При проведении корректировки таможенной стоимости товара КТС составляется на основе принятого таможенным органом решения о величине таможенной стоимости этого товара. Расчет скорректированной (уточненной) таможенной стоимости производится на бланке декларации таможенной стоимости. $\mathrm{K}$ расчетам уточненной величины таможенной стоимости товара должны прилагаться все документы, на основании которых эти расчеты производились. КТС составляет лицо, подавшее таможенную декларацию, если таможенным органом принята таможенная стоимость, скорректированная этим лицом; должностное лицо таможенного органа, если таможенный орган самостоятельно определяет таможенную стоимость.

\section{Таможенные платежи}

Расчет и уплата таможенных платежей - один из самых важных вопросов, связанных с ведением ВЭД.

В большинстве стран таможенные платежи являются важной составляющей доходной части бюджета, и их взимание таможенными органами рассматривается как одна из ведущих функций этих органов. Это характерно и для России. В соответствии с Бюджетным кодексом РФ пошлины, сборы и иные таможенные платежи являются налоговыми доходами федерального бюджета.

Таможенные платежи - таможенные пошлины (ввозные и вывозные), налоги (ввозные НДС и акциз), сборы (за таможенное сопровождение, за таможенное оформление), взимаемые таможенными органами в области таможенного дела.

Кроме таможенных платежей, таможенные органы наделены правом взимания иных платежей, не отнесенных ТК РФ к таможенным платежам.

Такими платежами являются:

- внутренние налоги;

- специальные, антидемпинговые и компенсационные пошлины;

Внутренние налоги, а также специальные, антидемпинговые и 
компенсационные пошлины взимаются таможенными органами в порядке, установленном ТК РФ для взимания таможенных платежей.

Bсе виды платежей, взимаемых таможенными органами, включая средства, получаемые в счет возмещения затрат на хранение товаров на складах временного хранения и таможенных складах таможенных органов, подлежат перечислению в федеральный бюджет.

К сожалению, четкого определения таможенных платежей на законодательном уровне пока нет. Так, например, в Налоговом кодексе РФ указывается лишь на основные их разновидности. Таможенный кодекс РФ более подробно перечисляет виды таможенных платежей (согласно ст. 318 ТК, к таможенным платежам относятся: ввозная таможенная пошлина; вывозная таможенная пошлина; налог на добавленную стоимость, взимаемый при ввозе товаров на таможенную территорию РФ; акциз, взимаемый при ввозе товаров на таможенную территорию РФ; таможенные сборы), но также не приводит общего понятия. Поэтому в качестве критериев таможенных платежей часто выделяют их единую правовую природу (отношение либо к налогам, либо к сборам), а также характерные черты, присущие всем таможенным платежам, позволяющие дифференцировать их на платежи, связанные с перемещением товаров через таможенную границу РФ, и платежи, непосредственно не связанные с таким перемещением.

Для участников ВЭД уплата таможенных платежей является неотъемлемым условием ввоза и вывоза товаров с таможенной территории, а также для совершения иных операций по таможенному декларированию товаров.

В рамках изучаемой дисциплины целесообразно уделить внимание тем таможенным платежам, которые связаны с перемещением товаров через таможенную границу РФ и являются обязательным условием такого перемещения. Иные таможенные платежи имеют фиксированные параметры, поэтому большой сложности для изучения не представляют.

В зависимости от обложения таможенной пошлиной ввозимых либо 
вывозимых товаров существует два вида таможенных пошлин:

- ввозная (импортная) таможенная пошлина;

- вывозная (экспортная) таможенная пошлина.

Наибольший перечень товаров (по видам) подлежит обложению ввозными таможенными пошлинами.

Вывозными таможенными пошлинами облагаются в основном товары, отнесенные к категории сырьевых, например, древесина и изделия из нее, древесный уголь, нефть сырая, нефтепродукты, спирт этиловый неденатурированный.

Правовые основы применения в РФ таможенных пошлин закреплены в законе РФ "О таможенном тарифе". Порядок уплаты таможенной пошлины устанавливается ТК РФ.

Адвалорная ставка таможенной пошлины устанавливается в процентах к таможенной стоимости облагаемого товара. Поэтому необходимая сумма таможенной пошлины рассчитывается как произведение таможенной стоимости и соответствующей ставки пошлины в процентах.

Специфическая ставка таможенной пошлины устанавливается в денежном выражении за определенную единицу облагаемых товаров. Например, пиво безалкогольное - 0,6 евро за 1 л или зажигалки карманные газовые (не подлежащие повторной заправке) - 5 евро за 1000 шт.

Комбинированная ставка таможенной пошлины включает в себя как стоимостные, так и количественные показатели перемещаемых товаров. При этом, в зависимости от вида комбинированной ставки, размер таможенной пошлины может определяться либо путем сравнения либо путем сложения полученных величин. Например, комбинированная ставка для одежды меховой овчинной - 20 \% таможенной стоимости, но не менее 30 евро за 1 шт. указывает на исчисление таможенной пошлины посредством последовательного определения величин по стоимостной $(20 \%$ таможенной стоимости) и количественной (30 евро за 1 шт.) составляющих ставки. Окончательный размер таможенной пошлины определяется путем сравнения по наибольшему 
показателю. Комбинированная ставка для спортивной обуви - 15 \% таможенной стоимости плюс 0,7 евро за пару, также указывает на последовательность расчета по стоимостной и количественной составляющим, однако размер таможенной пошлины определяется путем сложения полученных результатов.

Порядок взимания НДС и акцизов, в отношении товаров, перемещаемых через таможенную границу РФ, определяется Таможенным кодексом РФ и Налоговым кодексом Российской Федерации.

В соответствии с ТК РФ объектом обложения налогом на добавленную стоимость и акцизом являются товары, ввозимые на таможенную территорию РФ.

Налоговой базой для целей исчисления налога на добавленную стоимость и акциза является таможенная стоимость товаров и (или) их количество.

Вместе с тем, согласно абзацу 3 пункта 1 ст. 3 ТК РФ при регулировании отношений по установлению, введению и взиманию таможенных платежей таможенное законодательство РФ применяется в части, не урегулированной законодательством РФ о налогах и сборах.

В настоящее время вопросы объекта обложения налогом на добавленную стоимость и акцизом, а также определения налоговой базы при взимании данных видов таможенных платежей урегулированы частью второй Налогового кодекса Российской Федерации. Поэтому применению подлежат положения Налогового кодекса Российской Федерации.

Налог на добавленную стоимость (НДС) также, как и таможенная пошлина, имеет свои ставки. Однако виды этих ставок отличны от ставок таможенных пошлин. Во-первых, о разновидностях ставок НДС можно говорить только с количественной стороны: 10\% и 18\%. И, во-вторых, эти ставки применяются к широкому перечню товаров (в отличие от ставок таможенных пошлин, где каждой категории товаров соответствует своя ставка).

Для отдельных категорий продовольственных товаров (скот и птица в живом весе, молоко и молокопродукты, сахар, мука, макаронные изделия и ряд других товаров), а также товаров для детей (трикотажные изделия для новорожденных, подгузники, обувь, игрушки, школьные тетради для 
рисования и некоторые другие товары) в соответствии с НК РФ установлена ставка НДС в размере 10\%. В отношении иных товаров, ввозимых на таможенную территорию РФ, применяется ставка НДС в размере $18 \%$.

Налоговая база НДС определяется как сумма таможенной стоимости товара, таможенной пошлины и акциза. Соответственно, если товар не облагается акцизом и/или ввозной таможенной пошлиной, то данные виды таможенных платежей не включаются в налоговую базу.

Существующие льготы по уплате НДС предоставляются в виде освобождения от НДС либо возврата ранее уплаченных сумм и могут быть разделены по критериям их предоставления в зависимости от:

а) видов ввозимых товаров (необработанные природные алмазы, иностранная и российская валюта, банкноты, являющиеся законными средствами платежа (за исключением предназначенных для коллекционирования), акции, облигации, сертификаты, векселя и др.;

б) целей ввоза товаров (товары, предназначенные для официального пользования иностранными дипломатическими и приравненными к ним представительствами, а также для личного пользования дипломатического и административно - технического персонала этих представительств, включая членов их семей, проживающих вместе с ними, гуманитарная и техническая помощь и др.).

в) таможенного режима (реэкспорт, беспошлинная торговля, таможенный склад, транзит, переработка на таможенной территории, свободная таможенная зона и др.).

C 01.07 .2001 г. в отношении всех государств-участников СНГ (за исключением товаров белорусского происхождения) НДС взимается в общем порядке.

Порядок уплаты и возврата НДС соответствует общему порядку уплаты и возврата таможенных платежей.

В соответствии с пунктом 2 статьи 166 Таможенного кодекса РФ при экспорте товаров производятся освобождение от уплаты, возврат или 
возмещение внутренних налогов в соответствии с законодательством РФ о налогах и сборах.

Иными словами, налогообложение экспортных операций существенно отличается от налогообложения операций по реализации продукции, товаров, работ и услуг российским покупателям, а руководствоваться при исчислении налогов по экспортным сделкам нужно - как и при осуществлении операций на территории России - Налоговым кодексом РФ.

Порядок исчисления НДС - в том числе и при экспорте продукции, товаров, работ и услуг - регламентируется главой 21 Налогового кодекса РФ.

В соответствии с пунктом 1 статьи 164 Налогового кодекса РФ при реализации товаров, работ и услуг на экспорт налогообложение производится по ставке 0 процентов. Правда, для применения данной ставки необходимо представить в налоговую инспекцию пакет документов, подтверждающий осуществление экспорта.

Следует обратить внимание на то, что речь идет не об освобождении от уплаты НДС при осуществлении экспортных операций, а о применении ставки, равной 0 процентов. На первый взгляд может показаться, что это одно и то же - ведь ставка 0 процентов подразумевает, что НДС с экспортных операций не уплачивается (ведь любая сумма, умноженная на ноль, равна нулю). Однако на самом деле наличие налоговой ставки как таковой - независимо от ее размера - дает организации право на получение налоговых вычетов. Иными словами, организация-экспортер не взимает с иностранного покупателя ни копейки НДС, но имеет право предъявить суммы «входящего» НДС по сырью, материалам, товарам, работам и услугам, связанным с осуществлением экспорта (например, транспортным расходам), к вычету.

В соответствии с пунктом 3 статьи 153 Налогового кодекса РФ выручка от реализации товаров (работ, услуг) на экспорт, полученная в иностранной валюте, пересчитывается в рубли по курсу ЦБ РФ на дату оплаты отгруженных товаров (выполненных работ, оказанных услуг). В остальных случаях при определении налоговой базы выручку пересчитывают в рубли по курсу ЦБ РФ 
на дату, соответствующую моменту определения налоговой базы при реализации товаров (работ, услуг, имущественных прав), установленному статьей 167 Налогового кодекса РФ.

Обоснование права на применение налоговой ставки 0 процентов - отдельная декларация и пакет документов.

Для обоснования права на применение налоговой ставки 0 процентов по экспортным операциям организация обязана представлять в налоговые органы определенные документы. Кроме того, согласно пункту 6 статьи 164 Налогового кодекса РФ по экспортным операциям в налоговые органы должна представляться отдельная налоговая декларация.

Согласно пункту 1 статьи 165 Налогового кодекса РФ при реализации готовой продукции или товаров на экспорт, необходимо представить в налоговую инспекцию следующие документы:

1) контракт (копия контракта) налогоплательщика с иностранным лицом на поставку товара за пределы таможенной территории РФ;

2) выписка банка (копия выписки), подтверждающая фактическое поступление выручки от иностранного лица - покупателя указанного товара на счет налогоплательщика в российском банке;

3) Грузовая таможенная декларация / Транзитная декларация (ее копия) с отметками российского таможенного органа, осуществившего выпуск товаров в режиме экспорта, и пограничного таможенного органа (российского таможенного органа, в регионе деятельности которого находится пункт пропуска, через который товар был вывезен за пределы таможенной территории РФ);

4) копии транспортных, товаросопроводительных и (или) иных документов с отметками пограничных таможенных органов, подтверждающих вывоз товаров за пределы территории РФ.

В отдельных ситуациях вышеуказанный пакет документов может модифицироваться. Особенности представления документов в некоторых конкретных случаях также прописаны в статье 165 Налогового кодекса РФ. 
Так, при осуществлении внешнеторговых товарообменных (бартерных) операций вместо выписки банка налогоплательщик представляет в налоговые органы документы, подтверждающие ввоз товаров (выполнение работ, оказание услуг), полученных по указанным операциям, на территорию РФ и их оприходование. При вывозе товаров трубопроводным транспортом или по линиям электропередачи можно не предоставлять копии транспортных или товаросопроводительных документов. В случае осуществления экспорта через посредника предоставляется пакет документов, прописанный в пункте 2 статьи 165 Налогового кодекса РФ.

В любом случае данный пакет документов должен быть представлен в налоговую инспекцию в срок не позднее 180 дней, считая с даты помещения товара под таможенный режим экспорта. Этот срок установлен в пункте 9 статьи 165 Налогового кодекса РФ. При этом согласно пункту 9 статьи 167 Налогового кодекса РФ моментом определения налоговой базы при осуществлении экспортных операций считается последний день месяца, в котором собран полный пакет документов.

Указанный пакет документов согласно пункту 10 статьи 165 Налогового Кодекса РФ должен представляться в налоговую инспекцию вместе с налоговой декларацией - причем речь идет об отдельной налоговой декларации по НДС по ставке 0 процентов. Иными словами в случае, если организация реализует продукцию или товары и в России, и на экспорт, она подает две раздельные декларации. Формы деклараций и порядок их заполнения в настоящее время утверждены приказом Минфина РФ от 28.12.05 № 163 н. Срок подачи декларации по НДС по ставке 0 процентов - ежемесячно или ежеквартально до 20 числа месяца, следующего за истекшим налоговым периодом.

Если по истечении 180 дней с даты выпуска товаров на экспорт региональными таможенными органами организация-экспортер не сможет собрать и представить в налоговую инспекцию вышеуказанные документы, она обязана исчислить НДС с осуществленной экспортной операции по ставкам 10 процентов или 18 процентов соответственно в зависимости от того, какая 
ставка НДС должна применяться к вывезенным на экспорт товарам согласно пунктам 2 и 3 статьи 164 Налогового кодекса РФ.

При этом согласно пункту 9 статьи 167 Налогового кодекса РФ в подобной ситуации моментом определения налоговой базы считается день отгрузки. Следовательно, в случае, если пакет документов не собран на 181-й день, считая с даты помещения товаров под таможенный режим экспорта, операции по реализации данных товаров подлежат включению в декларацию по ставке 0 процентов за тот налоговый период, на который приходится день отгрузки товаров.

Особенностью акциза является то, что им облагаются только отдельные категории товаров, установленные Налоговым кодексом Российской Федерации.

К таким товарам, в частности, относятся:

- спирт этиловый из всех видов сырья (кроме спирта коньячного);

- спиртосодержащая продукция (растворы, эмульсии и др. виды продукции с объемной долей этилового спирта более 9 \%);

- алкогольная продукция (спирт питьевой, водка, ликероводочные изделия, коньяки, вина );

- Пиво;

- табачная продукция;

- автомобильный бензин;

- автомобили легковые;

- мотоциклы с мощностью двигателя свыше 112,5 кВт (150 л.с.);

- дизельное топливо;

- моторные масла для дизельных и (или) карбюраторных (инжекторных) двигателей.

Предусмотрены следующие ставки акцизов:

- адвалорные (устанавливаемые в процентах к налоговой безе, которая представляет собой сумму таможенной стоимости и таможенной пошлины);

- специфические (устанавливаемые в рублях и копейках за единицу 
измерения подакцизного товара или его технической характеристики (для легкового автомобиля, мотоцикла);

- комбинированные, то есть учитывающие и объем, и стоимость товара и рассчитываемые по формуле:

\section{(объем товара х специифическая ставка акциза) + (таможенная}

стоимость + ввозная таможенная пошлина) х адвалорная ставка акциза.

Существуют некоторые особенности в отношении взимания акцизов для товаров, подлежащих маркировке акцизными марками. Так, алкогольная продукция, табак и табачные изделия, ввозимые на таможенную территорию РФ и помещаемые под режим выпуска для свободного обращения, подлежат маркировке акцизными марками (в целях контроля за их оборотом). При этом оплата марок является авансовым платежом по акцизам.

Ставки авансового платежа в форме покупки акцизных марок устанавливаются Правительством Российской Федерации и не могут превышать одного процента установленной ставки акциза на алкогольную продукцию с объемной долей этилового спирта свыше 25 процентов. Цена одной акцизной марки на подакцизные товары, ввозимые на территорию РФ, установлена в размере 0,75 рубля - на алкогольную продукцию; 0,075 рубля - на табак и табачные изделия.

Сумма акциза по подакцизным товарам, подлежащим маркировке акцизными марками, исчисляется как сумма акциза, подлежащая уплате, за вычетом суммы авансового платежа, уплаченного при покупке акцизных марок.

Для акцизов предусмотрен также небольшой перечень льгот, предоставляемых в виде освобождения от их уплаты. Критериями такого освобождения могут выступать:

1) цель ввоза товара (товары, ввозимые физическими лицами для собственного использования в пределах установленных количественных ограничений);

2) таможенный режим (реэкспорт, транзит, уничтожение, таможенный склад, отказ в пользу государства, беспошлинная торговля и др.). 
С 01.07.2001 г. акцизы взимаются в отношении товаров, происходящих и ввозимых с территории всех государств-участников СНГ, за исключением Республики Беларусь.

При ввозе с территории Республики Беларусь подакцизных товаров, происходящих с ее территории, акциз взимается только в отношении товаров, подлежащих маркировке и(или) лицензированию.

Подлежащая уплате сумма акциза может быть уменьшена на сумму акцизов, уплаченных в бюджет Республики Беларусь (произведен зачет акциза) при соблюдении определенных условий.

Порядок уплаты и возврата акциза соответствует общему порядку уплаты и возврата таможенных платежей.

В соответствии с законом РФ "О внесении изменений в Таможенный кодекс Российской Федерации" (от 11 ноября 2004 г.) устанавливаются основные элементы уплаты таких видов таможенных платежей, как таможенные сборы. Согласно данному закону под таможенным сбором понимается платеж, уплата которого является одним из условий совершения таможенными органами действий, связанных с таможенным оформлением, хранением, сопровождением товаров, перемещаемых через таможенную границу Российской Федерации.

К таможенным сборам относятся:

1) таможенные сборы за таможенное оформление;

2) таможенные сборы за таможенное сопровождение;

3) таможенные сборы за хранение.

За таможенное оформление товаров, включая транспортные средства, перемещаемые через таможенную границу Российской Федерации в качестве товара, и товары не для коммерческих целей, перемещаемые в несопровождаемом багаже, международных почтовых отправлениях грузом, а также транспортных средств взимаются, если иное не установлено законодательством Российской Федерации, таможенные сборы в валюте Российской Федерации. С 1 января 2005 года таможенные органы перешли на 
новую форму взимания таможенных сборов.

За таможенное оформление товаров и транспортных средств вне определенных для этого мест, вне времени работы таможенных органов Российской Федерации таможенные сборы взимаются в двойном размере.

Сборы за таможенное оформление взимаются, например, при заявлении таможенных режимов:

- выпуск для внутреннего потребления;

- беспошлинная торговля;

- временный ввоз;

- временный вывоз;

- международный таможенный транзит.

Уплата таможенных сборов за таможенное оформление может производиться как в валюте РФ, так и в иностранной валюте, курс которой котируется ЦБ РФ, в соответствии с законодательством РФ о валютном регулировании и валютном контроле, по выбору плательщика.

Таможенные сборы за таможенное оформление взимаются при декларировании товаров. Ставки таможенных сборов за таможенное оформление устанавливаются Правительством РФ. Предельный размер таможенных сборов за таможенное оформление ограничивается приблизительной стоимостью оказанных таможенными органами услуг и не может быть более 100000 рублей.

С 1 января 2005 года таможенные сборы за таможенное оформление товаров, в том числе транспортных средств, перемещаемых через таможенную границу Российской Федерации в качестве товаров, уплачиваются по ставкам, приведенным в таблице 3.

Таможенные сборы за таможенное сопровождение представляют собой взнос, взимаемый за сопровождение таможенными органами транспортных средств, перевозящих товары в соответствии с внутренним таможенным транзитом. 


\section{Ставки таможенных сборов за таможенное оформление товаров}

\begin{tabular}{|l|c|}
\hline \multicolumn{1}{|c|}{ Таможенная стоимость товаров } & \multicolumn{1}{|c|}{$\begin{array}{c}\text { Сумма } \\
\text { таможенного сбора, } \\
\text { руб. }\end{array}$} \\
\hline Не превышает 200 000,00 рублей включительно & 500 \\
\hline $\begin{array}{l}\text { Составляет } 200000,01 \text { руб. и более, но не превышает } 450000,00 \text { руб. } \\
\text { включительно }\end{array}$ & 1000 \\
\hline $\begin{array}{l}\text { Составляет } 450000,01 \text { руб. и более, но не превышает } 1200000,00 \text { руб. } \\
\text { включительно }\end{array}$ & 2000 \\
\hline $\begin{array}{l}\text { Составляет } 1200000,01 \text { руб. и более, но не превышает } 2500000,00 \text { руб. } \\
\text { включительно }\end{array}$ & 5500 \\
\hline $\begin{array}{l}\text { Составляет } 2500000,01 \text { руб. и более, но не превышает } 5000000,00 \text { руб. } \\
\text { включительно }\end{array}$ & 7500 \\
\hline $\begin{array}{l}\text { Составляет } 5000000,01 \text { руб. и более, но не превышает } 10000000,00 \text { руб. } \\
\text { включительно }\end{array}$ & 20000 \\
\hline $\begin{array}{l}\text { Составляет } 10000 \text { 000,01 руб. и более, но не превышает } 30000000,00 \text { руб. } \\
\text { включительно }\end{array}$ & 50000 \\
\hline Составляет 30000 000,01 руб. и более & 100000 \\
\hline
\end{tabular}

Таможенные сборы за таможенное сопровождение уплачиваются в следующих размерах:

1) за осуществление таможенного сопровождения каждого автотранспортного средства и каждой единицы железнодорожного подвижного состава на расстояние:

- до 50 км - 2000 рублей;

- от 50 до 100 км - 3000 рублей;

- от 100 до 200 км - 4000 рублей;

- свыше 200 км - 1000 рублей за каждые 100 км пути, но не менее 6000 рублей;

2) за осуществление таможенного сопровождения каждого морского, речного или воздушного судна - 20000 рублей, независимо от расстояния перемещения.

Таможенные сборы за хранение взимаются в случаях хранения товаров на складах таможенных органов (на складе временного хранения таможенного органа и таможенном складе). Таможенные сборы за хранение уплачиваются в размере - 1 рубля с каждых 100 килограммов веса товаров в день, а в специально оборудованных помещениях - 2 рубля с каждых 100 килограммов 
веса товаров в день. Неполные 100 килограммов веса товаров приравниваются к полным 100 килограммам, а неполный день - к полному.

В соответствии со ст. 357 ТК РФ (с учетом изменений от 29.10.2004г.) таможенные сборы за таможенное оформление не взимаются в отношении товаров:

- относящихся в соответствии с законодательством РФ к безвозмездной помощи;

- перемещаемых через таможенную границу РФ дипломатическими и иными официальными представительствами и товаров, предназначенных для личного пользования некоторых категорий иностранных лиц, пользующихся привилегиями на территории РФ;

- предназначенных для выставок и т.д. по решению Правительства РФ;

- помещаемых под таможенный режим международного таможенного транзита при совпадении таможенного органа отправления и таможенного органа назначения;

- перемещаемых физическими лицами для личного пользования и т.д.

Таможенные сборы за хранение не взимаются:

- при помещении таможенными органами товаров на склад временного хранения или на таможенный склад таможенного органа;

- в иных случаях, определяемых Правительством Российской Федерации.

При этом Правительство РФ вправе определять случаи освобождения от уплаты таможенных сборов за таможенное сопровождение (ст. 357 ТК РФ).

При перемещении товаров через таможенную границу обязанность по уплате таможенных пошлин, налогов возникает при ввозе товаров - с момента пересечения таможенной границы, а при вывозе товаров - с момента подачи таможенной декларации или совершения действий, непосредственно направленных на вывоз товаров с таможенной территории Российской Федерации.

Таможенные пошлины, налоги не уплачиваются в случае, если:

- в соответствии с законодательством Российской Федерации или 
Таможенным кодексом:

- товары не облагаются таможенными пошлинами, налогами;

- в отношении товаров предоставлено условное полное освобождение от уплаты таможенных пошлин, налогов;

- общая таможенная стоимость товаров, ввозимых на таможенную территорию Российской Федерации в течение одной недели в адрес одного получателя, не превышает 5000 рублей;

- до выпуска товаров для свободного обращения и при отсутствии нарушений лицами требований и условий, установленных ТК РФ, иностранные товары оказались уничтоженными или безвозвратно утерянными вследствие аварии или действия непреодолимой силы либо в результате естественного износа или убыли при нормальных условиях транспортировки, хранения или использования (эксплуатации);

- товары обращаются в федеральную собственность в соответствии с ТК РФ и другими федеральными законами.

Таможенные пошлины, налоги исчисляются плательщиком. Исключения из данного правила составляют следующие случаи:

- выставление таможенным органом требования об уплате таможенных платежей;

- исчисление таможенным органом таможенных платежей при перемещении товаров в международных почтовых отправлениях;

- дополнительные начисления таможенных платежей таможенным органом по результатам проверки сведений, заявленных декларантом. Дополнительные начисления возможны, например, в случаях:

- установления недостоверности сведений о стране происхождения товаров;

- установления нарушений правил классификации товаров в соответствии с Товарной номенклатурой внешнеэкономической деятельности;

- самостоятельного определения таможенным органом таможенной стоимости товаров; 
- самостоятельного определения таможенным органом количества товаров.

Как уже было отмечено выше, исчисление сумм подлежащих уплате таможенных пошлин, налогов производится в валюте РФ. Вместе с тем, по выбору плательщика, таможенные пошлины, налоги могут уплачиваться как валюте РФ, так и в иностранных валютах, курсы которых котируются ЦБ РФ.

Пересчет валюты РФ в иностранную валюту для целей уплаты таможенных пошлин, налогов, исчисленных в валюте РФ, производится по курсу, действующему на день принятия таможенным органом таможенной декларации, а в случаях, когда обязанность уплаты таможенных пошлин, налогов не связана с подачей таможенной декларации, - на день фактической уплаты.

Как правило, для целей исчисления таможенных пошлин, налогов применяются ставки, действующие на день принятия таможенной декларации таможенным органом. Исключения из данного правила составляют случаи:

- выпуска товаров до подачи таможенной декларации;

- уплаты таможенных пошлин в отношении товаров, перемещаемых трубопроводным транспортом;

- уплаты таможенных пошлин, налогов в отношении товаров, незаконно перемещенных через таможенную границу РФ либо использованных на таможенной территории РФ в нарушение требований таможенных процедур внутреннего таможенного транзита или временного хранения.

Сроком уплаты таможенных платежей является период времени, в течение которого требуется уплатить необходимые суммы, или событие, с возникновением которого ТК РФ связывает необходимость уплаты таможенных платежей.

В соответствии со статьей 329 ТК РФ существуют следующие виды сроков уплаты таможенных платежей:

1. При ввозе товаров на таможенную территорию РФ - 15 дней со дня предъявления товаров в таможенный орган в месте их прибытия или 15 дней со 
дня завершения внутреннего таможенного транзита, если место таможенного декларирования отлично от места прибытия товаров на таможенную территорию.

2. При вывозе товаров срок уплаты таможенных платежей не имеет, как такового, периода и определен событием, с которым связано, в том числе возникновение обязанности по уплате таможенных платежей, а именно, подачей таможенной декларации.

Отдельные исключения из этого правила предусмотрены в случаях применения периодического временного декларирования российских товаров, а также при перемещении товаров трубопроводным транспортом.

3. При изменении таможенного режима таможенные платежи должны быть уплачены не позднее дня завершения действия изменяемого таможенного режима (например, день истечения сроков хранения товаров в режиме таможенного склада).

4. При нецелевом использовании условно выпущенных товаров сроком уплаты таможенных платежей является первый день, когда лицом были нарушены ограничения по пользованию и распоряжению товарами (например, продажа товаров, ввезенных в качестве вклада иностранного инвестора в уставный (складочный) капитал организаций с иностранными инвестициями или продажа товара, ввезенного в качестве гуманитарной помощи). Если такой день установить невозможно, сроком уплаты таможенных платежей считается день принятия таможенным органом таможенной декларации при условном выпуске данных товаров.

5. При нарушении требований и условий таможенных процедур, которое влечет за собой обязанность уплаты таможенных платежей, сроком такой уплаты считается день совершении данного нарушения (например, утрата или выдача без разрешения таможенного органа товаров, перевозимых по процедуре внутреннего таможенного транзита, хранящихся на складе временного хранения, или помещенных под таможенный режим таможенного склада, магазина беспошлинной торговли). Если такой день установить 
невозможно, сроком уплаты таможенных платежей считается день начала действия соответствующей таможенной процедуры (например, день прибытия товаров на таможенную территорию, день получения письменного разрешения на внутренний таможенный транзит, день завершения внутреннего таможенного транзита, день помещения товаров под избранный таможенный режим).

6. Сроки уплаты таможенных платежей в случае применения специальных таможенных процедур установлены для каждой такой процедуры в отдельности. Например, физические лица, перемещающие товары в ручной клади и сопровождаемом багаже, уплачивают таможенные платежи непосредственно при следовании через Государственную границу Российской Федерации.

7. Сроки уплаты таможенных платежей, устанавливаемые для отдельных случаев таможенными органами или заинтересованными лицами, с согласия таможенных органов. Например, сроки уплаты таможенных платежей, в отношении временно ввезенных товаров (при уплате периодических сумм таможенных пошлин, налогов), сроки предоставления отсрочки или рассрочки уплаты таможенных платежей.

8. Сроки уплаты таможенных платежей в отношении незаконно ввезенных товаров, обнаруженных у их приобретателей (организаций, осуществляющих оптовую или розничную продажу ввезенных товаров) на территории РФ. В соответствии с ТК РФ товары рассматриваются выпущенными для свободного обращения, если лица уплачивают таможенные платежи не позднее пяти дней со дня обнаружения у них товаров.

ТК РФ предусматривается изменение срока уплаты таможенных пошлин, налогов в форме отсрочки, либо рассрочки.

Отсрочка или рассрочка уплаты таможенных пошлин, налогов может предоставляться по одной или нескольким видам таможенных пошлин, налогов, а также в отношении всей суммы, подлежащей уплате, либо ее части.

Предоставление отсрочки либо рассрочки возможно на срок от одного до 
шести месяцев и при наличии одного из следующих оснований:

- причинения плательщику ущерба в результате стихийного бедствия, технологической катастрофы или иных обстоятельств непреодолимой силы;

- задержки плательщику финансирования из федерального бюджета или оплаты выполненного плательщиком государственного заказа;

- перемещения плательщиком через таможенную границу товаров, являющихся товарами, подвергающимися быстрой порче;

- осуществления плательщиком поставок по межправительственным соглашениям.

В случаях возбуждения в отношении плательщика уголовного дела по признакам таможенного преступления или возбуждения процедуры банкротства, таможенный орган отказывает в выдаче разрешения либо отменяет ранее принятое решение об изменении срока уплаты таможенных платежей.

Изменение срока уплаты таможенных пошлин, налогов сопровождается:

- взиманием процентов (начисляемых на сумму задолженности), исходя из ставки рефинансирования ЦБ РФ, действующей в период отсрочки или рассрочки;

- обеспечением уплаты таможенных платежей.

Исполнение обязанности по уплате таможенных платежей - совершение плательщиком действий, освобождающих его от обязанности по уплате платежа в отношении перечисленной суммы.

При соблюдении требований таможенных операций и процедур дата уплаты таможенного платежа не должна превышать установленные сроки уплаты. Иначе, в части превышения таких сроков образуется недоимка, с которой взимается определенный процент (пени), за просрочку уплаты таможенного платежа.

Пени начисляются за каждый календарный день просрочки уплаты таможенных пошлин, начиная со дня, следующего за днем истечения сроков уплаты таможенных пошлин, налогов по день исполнения обязанности по 
уплате таможенных пошлин, налогов либо по день принятия решения о предоставлении отсрочки или рассрочки уплаты таможенных пошлин, налогов включительно, в процентах, соответствующих одной трехсотой ставки рефинансирования ЦБ от суммы неуплаченных таможенных пошлин, налогов (недоимки).

Исключение составляют случаи:

- выставления требования об уплате таможенных пошлин, налогов поручителю или гаранту (начисляются не более чем за три месяца со дня, следующего за днем истечения сроков исполнения обязательств, обеспеченных поручительством или банковской гарантией);

- исполнения требования таможенного органа об уплате таможенных пошлин, налогов в установленный в требовании срок (пени уплачиваются с момента образования недоимки до момента выставления требования, в противном случае пени уплачиваются с момента образования недоимки по день исполнения обязанности по уплате таможенных пошлин, налогов включительно, либо по день принятия решения о предоставлении отсрочки или рассрочки уплаты таможенных пошлин, налогов);

- нарушения срока подачи таможенной декларации при нахождении товаров на складе временного хранения (за период временного хранения пени не начисляются и уплате не подлежат);

- доплаты в течение 10 рабочих дней со дня получения требования об уплате таможенных платежей, дополнительно начисленных таможенных пошлин, налогов в случае самостоятельного определения таможенным органом таможенной стоимости товаров;

- доплаты вывозных таможенных пошлин при периодическом временном декларировании российских товаров (на момент подачи полной таможенной декларации;

- доплаты таможенных пошлин, налогов в течение 10 рабочих дней со дня принятия таможенным органом решения о необходимости уплаты указанных сумм по результатам выверки количества продуктов переработки (при 
применении таможенных режимов переработки на таможенной территории и переработки вне таможенной территории);

- доплаты сумм таможенных пошлин, налогов в связи с представлением в таможенный орган уточненных сведений о товарах, перемещаемых трубопроводным транспортом;

- невозможности уплаты таможенных пошлин, налогов по причине принятия таможенным органом или судом решений о приостановлении операций плательщика в банке или наложении ареста на имущество плательщика.

Момент исполнения обязанности по уплате таможенных платежей зависит от той формы и сроков уплаты, которую избирает плательщик (безналичная форма уплаты, внесение денежных средств в кассу таможенного органа, применение микропроцессорных пластиковых карт, зачет авансовых сумм или денежного залога).

На основании ст. 332 ТК РФ обязанность по уплате таможенных пошлин, налогов считается исполненной в следующих случаях:

1. С момента списания денежных средств со счета плательщика в банке.

Для целей подтверждения данного факта плательщиком предоставляется таможенному органу платежное поручение с отметкой банка о списании соответствующих сумм. На основании ст. 149 ТК РФ в случае непоступления сумм таможенных пошлин, налогов на счета таможенных органов товары считаются условно выпущенными. Таможенные органы не вправе требовать подтверждение поступления денежных средств на счета таможенных органов.

В случаях уплаты таможенных пошлин, налогов с помощью микропроцессорной пластиковой (таможенной карты) подтверждением уплаты таможенного платежа служит платежный документ, сформированный электронным терминалом и подписанный держателем таможенной карты и инспектором таможни.

2. С момента внесения наличных денежных средств в кассу таможенного органа. 
Для юридических лиц эта сумма устанавливается до 60 тысяч рублей (на основании указания ЦБ РФ от 14 ноября 2001 г. № 1050-У "Об установлении предельного размера расчетов наличными деньгами в Российской Федерации между юридическими лицами"). При осуществлении таможенного платежа наличными оформляется таможенный приходный ордер (ТПО).

3. С момента зачета (по инициативе плательщика) излишне уплаченных или излишне взысканных сумм таможенных пошлин, налогов в качестве таможенных платежей. Моментом зачета является принятие таможенным органом такого заявления.

4. С момента зачета (по инициативе плательщика) авансовых сумм или денежного залога в качестве таможенных платежей.

Моментом зачета является получение таможенным органом распоряжения о зачете.

При наличии авансовых сумм на счете таможенного органа в качестве распоряжения о зачете рассматривается поданная таможенная декларация (применительно к суммам таможенных пошлин, налогов, указанных в ней).

В случае использования денежного залога для целей уплаты таможенных пошлин, налогов, помимо распоряжения о зачете, требуется подтвердить исполнение обязательства, которое обеспечивалось денежным залогом. Например, предоставить свидетельство о завершении внутреннего таможенного транзита, если в соответствии со ст. 86 ТК РФ применялось обеспечение уплаты таможенных платежей.

5. С момента зачета в счет уплаты таможенных пошлин, налогов денежных средств, уплаченных банком, иной кредитной организацией либо страховой организацией в соответствии с банковской гарантией или договором страхования, а также поручителем в соответствии с договором поручительства.

6. С момента обращения взыскания на товары, в отношении которых не уплачены таможенные платежи, либо на предмет залога или иное имущество плательщика, если размер сумм указанных денежных средств не менее суммы задолженности по уплате таможенных пошлин, налогов. Указанные в двух 
последних пунктах денежные средства должны фактически поступить на счет таможенного органа.

Таможенные платежи уплачиваются в кассу или на счет таможенного органа, открытый для этих целей, а при перемещении товаров в международных почтовых отправлениях - организации почтовой связи, которая затем переводит денежные суммы на счет соответствующего таможенного органа (таможенного органа, который их и начислил при осуществлении таможенного оформления товара в месте международного почтового обмена).

Таможенные платежи могут быть уплачены в любой форме. К формам уплаты таможенных платежей относятся:

- безналичный расчет (платежное поручение, таможенные карты, зачет авансовых сумм, денежного залога, излишне уплаченных и излишне взысканных платежей);

- наличный расчет (оформление таможенного приходного ордера).

Как уже было отмечено выше, таможенные платежи уплачиваются по выбору плательщика как в валюте Российской Федерации, так и в иностранной валюте, курс которой котируется Центральным банком Российской Федерации, в соответствии с законодательством Российской Федерации о валютном регулировании и валютном контроле.

Обеспечение уплаты таможенных платежей следует рассматривать как универсальный механизм гарантии выполнения обязательств перед государством со стороны участников ВЭД, а также юридических лиц, которые осуществляют свою деятельность в околотаможенной сфере: складов временного хранения (CBX), таможенных складов, таможенных перевозчиков и таможенных брокеров. Смысл этого механизма состоит в том, что участник ВЭД вправе внести один из видов обеспечения, а таможня - выпустить товар, что крайне важно для сокращения времени таможенного оформления и увеличения скорости товарооборота.

Применение обеспечения уплаты таможенных платежей имеет место в 
случаях:

-изменения срока уплаты таможенных платежей (предоставление отсрочки или рассрочки);

- условного выпуска товаров;

- перевозки или хранения иностранных товаров (внутренний таможенный транзит, временное хранение товаров на складе получателя);

- осуществления деятельности в области таможенного дела;

- обнаружения таможенным органом товаров, в отношении которых не были уплачены таможенные платежи или не соблюдены иные требования ТК РФ.

Обеспечение уплаты таможенных платежей не предоставляется, если сумма подлежащих уплате таможенных пошлин, налогов не превышает двадцати тысяч рублей, а также в случаях, когда таможенный орган имеет основания полагать, что обязательства, взятые перед ним, будут выполнены.

Исключения составляют случаи, когда в специальных статьях ТК РФ предоставление обеспечения уплаты таможенных платежей выступает в качестве одного из условий применения соответствующей таможенной процедуры, например, при помещении товаров в режим беспошлинной торговли.

ТК РФ предусматривает следующие способы обеспечения уплаты таможенных пошлин, налогов:

1. Залог товаров и иного имущества.

Предметом залога являются товары, ввозимые на таможенную территорию РФ, а также иное имущество, которое может быть предметом залога в соответствии с гражданским законодательством РФ. Договор о залоге заключается с оставлением предмета у залогодателя с передачей заложенного имущества залогодержателю (таможне).

2. Банковская гарантия.

Банковские гарантии вправе выдавать только банки, кредитные организации или страховые организации, включенные в Реестр банков и иных кредитных организаций. Порядок включения банков, кредитных организаций 
или страховых организаций в соответствующий Реестр установлен ТК РФ (приказ ГТК России от 1 сентября 2003 г. "Об утверждении Правил ведения Реестра банков и иных кредитных организаций" и приказ ГТК России № 405 "Об утверждении Реестра банков и иных кредитных организаций").

3. Внесение денежных средств в кассу или на счет таможенного органа в федеральном казначействе (денежный залог).

В подтверждение внесения денежного залога лицу, внесшему денежные средства в кассу или на счет таможенного органа, выдается таможенная расписка (приказ ГТК России от 24 ноября 2003 г. № 1311 "Об утверждении формы таможенной расписки, добавочных листов к таможенной расписке, а также инструкции о порядке заполнения и использования таможенной расписки"). Проценты на сумму денежного залога не начисляются.

При исполнении обязательства, обеспеченного денежным залогом, уплаченные денежные средства подлежат возврату или, по желанию плательщика, - использованию для уплаты таможенных платежей, зачету в счет будущих таможенных платежей, либо для обеспечения уплаты таможенных платежей по другому обязательству перед таможенными органами. Денежный залог возвращается таможенным органом, на счет или в кассу которого суммы денежного залога были уплачены, либо таможенным органом, в котором завершаются таможенная процедура или таможенный режим, обязательства исполнения которых были обеспечены денежным залогом.

4. Поручительство.

В соответствии с ТК РФ в качестве поручителя могут выступать таможенные брокеры, владельцы складов временного хранения, владельцы таможенных складов, магазинов беспошлинной торговли, а также иные лица.

Обеспечение уплаты таможенных платежей может производиться любым способом по выбору плательщика. Причем, одно обязательство может обеспечиваться несколькими способами, также как и несколько обязательств могут обеспечиваться одним способом (генеральное обеспечение).

По общему правилу, закрепленному в пункте 1 ст. 338 ТК РФ, размер 
обеспечения уплаты таможенных платежей определяется таможенным органом, исходя из сумм таможенных платежей и процентов, подлежащих уплате при выпуске товаров для свободного обращения или их вывозе в соответствии с таможенным режимом экспорта, и не может превышать размер указанных сумм.

Исключения составляют случаи:

- определения размера обеспечения уплаты таможенных платежей как разницы между суммами таможенных платежей, исчисленных таможенным органом, и суммой таможенных платежей, уплаченных декларантом;

- установления ФТС России фиксированного размера обеспечения уплаты таможенных платежей в отношении отдельных видов товаров (например, подакцизных).

\subsection{3. Валютное регулирование ВЭД}

Основным законодательным актом, на котором строится вся система валютного законодательства, является Ф3 «О валютном регулировании и валютном контроле» от 10.12.03 № 173-Ф3 (ред. ФЗ от 22.07.2008 N 150-Ф3).

В целях соблюдения правил валютного контроля предусмотрен механизм, предусматривающий открытие импортерами и экспортерами в уполномоченном банке, где открыт валютный счет российского контрагента (через который осуществляются платежи по внешнеторговому контракту), паспорта сделки (ст. 20 ФЗ о валютном контроле).

ЦБ РФ разработал единые правила открытия паспорта сделки, его заполнения, внесения в него изменений, закрытия, порядок перевода контракта в другой уполномоченный банк и т.д. Они предусмотрены двумя основными документами:

1) Инструкция ЦБ РФ от 15.06.2004 №117-И «О порядке представления резидентами и нерезидентами уполномоченным банкам документов и информации при осуществлении валютных операций, порядке учета уполномоченными банками валютных операций и оформления паспортов сделок». 
2) Положение ЦБ РФ от 01.06.04 г. № 258-П «О порядке представления резидентами уполномоченным банкам подтверждающих документов и информации, связанных с проведением валютных операций с нерезидентами по внешнеторговым сделкам, и осуществления уполномоченными банками контроля за проведением валютных операций» (в редакции Указания ЦБ РФ от 26.09.2008 № 2080-У).

Для открытия паспорта сделки необходимо предоставить контракт и два заполненных экземпляра самого паспорта сделки, подписанные всеми лицами, подпись которых имеется в банковской карточке образцов подписей, или высланные по системе клиент-банк (в случае, если внутренний порядок банка позволяет считать документы, принятые таким образом, подписанными электронной цифровой подписью). Банку дается 3 рабочих дня для проверки контракта, после чего он принимает решение об открытии паспорта сделки.

Не требуется оформление паспорта сделки по контрактам (кредитным договорам), общая сумма которых не превышает эквивалент 5000 долларов США по курсу ЦБ РФ на дату подписания контракта.

В целях осуществления валютного контроля банк имеет право запрашивать и получать от резидентов и нерезидентов документы (копии документов), связанные с проведением валютных операций, открытием и ведением счетов, указанные в ст.23 Ф3 № 173-Ф3, в частности:

Пункт 6: документы, удостоверяющие права нерезидентов на осуществление валютных операций, открытие счетов (вкладов), оформляемые и выдаваемые органами страны места жительства (места регистрации) нерезидента, если получение нерезидентом такого документа предусмотрено законодательством иностранного государства;

Пункт 9: документы (проекты документов), являющиеся основанием для проведения валютных операций, включая договоры (соглашения, контракты), доверенности, выписки из протокола общего собрания или иного органа управления юридического лица; документы, содержащие сведения о результатах торгов (в случае их проведения); документы, подтверждающие 
факт передачи товаров (выполнения работ, оказания услуг), информации и результатов интеллектуальной деятельности, в том числе исключительных прав на них, акты государственных органов;

Пункт 11: таможенные декларации, документы, подтверждающие ввоз в Российскую Федерацию валюты Российской Федерации, иностранной валюты и внешних и внутренних ценных бумаг в документарной форме.

Перечень операций, по которым резиденту необходимо представить документы в банк, а также сроки их предоставления:

1) После получения отправки товаров по контракту, если по нему в банке оформлен паспорт сделки, подтверждающих документов в банк представляются документы, подтверждающие ввоз/вывоз товаров (ГТД, ТТН или др.) в течение 15 календарных дней после их оформления, вместе со Справкой о подтверждающих документах (2 экземпляра).

В том же порядке в банк представляются документы, подтверждающие факт выполнения работ, услуг, передачу результатов интеллектуальной деятельности или информации.

При поступлении денежных средств в оплату экспортируемых товаров, работ, услуг, результатов интеллектуальной деятельности и информации, при получении кредита, займа и т.д., резидент в течение 7 рабочих дней с даты поступления средств представляет в банк:

- при поступлении иностранной валюты — Распоряжение о списании средств с транзитного счета (3 экземпляра), а также Справку о валютной операции (1 экземпляр);

• при поступлении валюты РФ - Справку о поступлении валюты РФ (2 экземпляра) в сроки, установленные п.П. 2.7 Положения Банка России от 01.06.2004 № 258-П.

2) При списании (переводе) валюты иностранному партнеру в банк предоставляются документы, являющиеся основанием для перечисления денег (счета на оплату, коносаменты и т.п.), - согласно условиям оплаты во внешнеторговом договоре, а также Поручение на покупку иностранной валюты 
(в 3 экземплярах), и Заявление на перевод (в 1 экземпляре), оформляется Справка о валютных операциях.

3) При осуществлении расчетов по внешнеторговому контракту через счета, открытые в банке-нерезиденте, в течение 45 календарных дней, следующих за месяцем, в котором были осуществлены расчеты, предоставляется Справка, содержащая информацию о валютных операциях по контракту за отчетный месяц с приложением к ней копий банковских выписок, подтверждающих осуществление валютных операций по контракту (в 2 экземплярах).

Ответственность за валютные правонарушения устанавливается Кодексом Российской Федерации об административных нарушениях от 30.12.2001 N 195-Ф3 (в ред. от 22.07.2008). Валютным правонарушениям посвящена статья 15.25 КоАПРФ, которая предусматривает ответственность за:

1. Осуществление незаконных валютных операций, то есть, запрещенных валютным законодательством Российской Федерации (предусмотрен штраф в размере от трех четвертых до одного размера суммы незаконной валютной операции).

2. Нарушение установленного порядка открытия счетов (вкладов) в банках, расположенных за пределами территории Российской Федерации (влечет штраф для граждан в размере от одной тысячи до одной тысячи пятисот рублей; для должностных лиц - от пяти тысяч до десяти тысяч рублей; для юридических лиц - от пятидесяти тысяч до ста тысяч рублей).

3. Невыполнение резидентом в установленный срок обязанности по получению на свои банковские счета в уполномоченных банках иностранной валюты или валюты Российской Федерации, причитающихся за переданные нерезидентам товары, выполненные для нерезидентов работы, оказанные нерезидентам услуги либо за переданные нерезидентам информацию или результаты интеллектуальной деятельности, в том числе исключительные права на них (влечет наложение штрафа на должностных лиц и юридических лиц в размере от трех четвертых до одного размера суммы денежных средств, не 
зачисленных на счета в уполномоченных банках).

4. Невыполнение резидентом в установленный срок обязанности по возврату в Российскую Федерацию денежных средств, уплаченных нерезидентам за не ввезенные на таможенную территорию Российской Федерации (не полученные на таможенной территории Российской Федерации) товары, невыполненные работы, неоказанные услуги либо за непереданные информацию или результаты интеллектуальной деятельности, в том числе исключительные права на них (влечет штраф в размере от трех четвертых до одного размера суммы денежных средств, не возвращенных в Российскую Федерацию).

5. Несоблюдение установленных порядка или сроков представления форм учета и отчетности по валютным операциям, нарушение установленного порядка использования специального счета и (или) резервирования, нарушение установленных единых правил оформления паспортов сделок либо нарушение установленных сроков хранения учетных и отчетных документов или паспортов сделок (штраф для должностных лиц в размере от четырех тысяч до пяти тысяч рублей; для юридических лиц - от сорока тысяч до пятидесяти тысяч рублей).

6. Нарушение установленного порядка ввоза и пересылки в Российскую Федерацию и вывоза и пересылки из Российской Федерации валюты Российской Федерации и внутренних ценных бумаг в документарной форме (штраф для граждан в размере от пятисот до одной тысячи рублей; для должностных лиц - от одной тысячи до двух тысяч рублей; на юридических лиц - от пяти тысяч до десяти тысяч рублей).

Неоформление паспорта сделки, несоблюдение сроков подачи подтверждающих документов, задержка представления справок о поступлении валюты являются отдельными правонарушениями. При невыполнении установленных правил организация должна будет уплатить штраф за каждое правонарушение в отдельности, даже если нарушения имели место в рамках одной сделки. 


\section{3.Этапы и элементы контроля внешнеэкономической деятельности}

Внешнеэкономическая деятельность организации представляет собой деятельность, контролируемую различными контролирующими органами и организациями для проверки правильности ведения валютных операций, предотвращения утечки капитала за границу, проверки законности проведения внешнеэкономических сделок.

Контроль внешнеэкономической деятельности является многоуровневым и всесторонним. К органам, осуществляющим контроль, относятся:

- государственные контролирующие органы, осуществляющие контроль за поступлением и расходованием средств бюджетов всех уровней;

- ведомственные контрольно - ревизионные службы, контролирующие финансово - хозяйственную деятельность подведомственных организаций;

- аудиторские фирмы и индивидуальные аудиторы, осуществляющие аудит и оказывающие сопутствующие аудиту услуги на договорных условиях с хозяйствующими субъектами;

- внутрихозяйственные контрольные службы, осуществляющие контрольные функции непосредственно в организациях, а именно: ревизионные комиссии, служба внутреннего аудита, инвентаризационные комиссии.

Стоит отметить, что каждому контролирующему органу соответствуют свои задачи и функции.

Государственный контроль предназначен для реализации финансовой политики государства, создания условий для финансовой стабилизации. К основным задачам государственного контроля внешнеэкономической деятельности относятся:

- контроль за выполнением денежных обязательств перед государством, включая налоги и другие обязательные платежи; 
- оценка соблюдения установленных правил организации денежных расчетов, ведения бухгалтерского учета и составления бухгалтерской отчетности.

Виды государственного контроля внешнеэкономической деятельности в Российской Федерации можно представить с помощью рисунка 1.

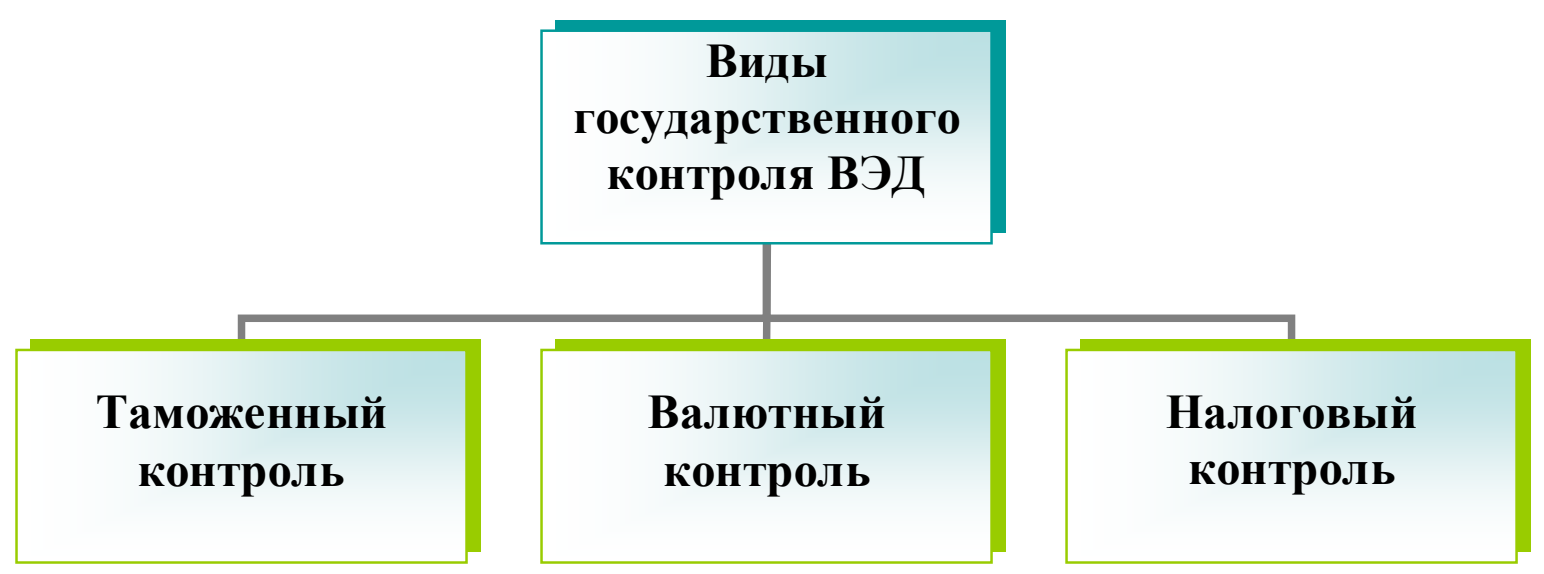

Рис. 1. Виды государственного контроля ВЭД

Характеристику видов государственного контроля за внешнеэкономической деятельностью можно представить с помощью таблицы 4.

В России организация таможенного контроля возложена на Федеральную Таможенную службу (ФТС) России, которая издает нормативные акты по таможенному контролю.

Валютный контроль направлен на защиту устойчивости национальной денежной единицы.

Налоговый контроль осуществляет контроль за полнотой и своевременностью уплаты налогов всеми организациями - участниками ВЭД, зарегистрированными в соответствии с законодательством РФ и обязанными платить налоги. В России осуществление налогового контроля возложено на Федеральную налоговую службу (ФНС). 
Таблица 4

Характеристика видов государственного контроля за ВЭД в России ${ }^{1}$ [16]

\begin{tabular}{|c|c|c|c|c|}
\hline $\begin{array}{l}\text { № } \\
\text { ПI/ா }\end{array}$ & Признак & $\begin{array}{c}\text { Таможенный } \\
\text { контроль }\end{array}$ & Валютный контроль & $\begin{array}{c}\text { Налоговый } \\
\text { контроль }\end{array}$ \\
\hline 1 & 2 & 3 & 4 & 5 \\
\hline 1. & $\begin{array}{c}\text { Нормативный } \\
\text { документ }\end{array}$ & $\begin{array}{c}\text { Таможенный кодекс РФ } \\
\text { Закон «О таможенном } \\
\text { тарифе» } \\
\text { Письмо ФТС от } \\
01.11 .2004 \text { г. } \\
\text { № } 13-15 / 5393 \text { «Об } \\
\text { оформлении паспортов } \\
\text { сделок» }\end{array}$ & $\begin{array}{c}\text { Закон «О валютном } \\
\text { регулировании и } \\
\text { валютном контроле» } \\
\text { Указания и письма ЦБ } \\
\text { РФ }\end{array}$ & $\begin{array}{c}\text { Налоговый кодекс РФ } \\
\text { Методические } \\
\text { указания и письма } \\
\text { ФНС }\end{array}$ \\
\hline 2. & Орган контроля & $\begin{array}{c}\text { Федеральная } \\
\text { таможенная служба } \\
\text { РФ (ФТС) }\end{array}$ & $\begin{array}{c}\text { Банк России } \\
\text { Правительство РФ }\end{array}$ & $\begin{array}{c}\text { Федеральная } \\
\text { налоговая служба } \\
\text { РФ (ФНС) }\end{array}$ \\
\hline 3. & Агенты контроля & $\begin{array}{c}\text { Таможенные } \\
\text { органы }\end{array}$ & Уполномоченные банки & $\begin{array}{l}\text { Территориальные } \\
\text { инспекции ФНС }\end{array}$ \\
\hline 4. & $\begin{array}{c}\text { Основные } \\
\text { документы } \\
\text { контроля }\end{array}$ & $\begin{array}{c}\text { Грузовая таможенная } \\
\text { декларация/Транзитная } \\
\text { декларация } \\
\text { Декларация } \\
\text { таможенной стоимости } \\
\text { Декларация о } \\
\text { происхождении товара }\end{array}$ & $\begin{array}{c}\text { Паспорт импортной сделки } \\
\text { Паспорт экспортной сделки } \\
\text { Паспорт } \\
\text { внешнеэкономической } \\
\text { бартерной сделки }\end{array}$ & $\begin{array}{l}\text { Налоговые } \\
\text { декларации }\end{array}$ \\
\hline 5. & $\begin{array}{l}\text { Субъекты } \\
\text { контроля }\end{array}$ & Декларанты & $\begin{array}{l}\text { Резиденты и } \\
\text { нерезиденты }\end{array}$ & Налогоплательщики \\
\hline
\end{tabular}

При организации контроля за внешнеэкономической деятельностью работа контролирующих органов осуществляется в несколько этапов, представленных на рисунке 2.

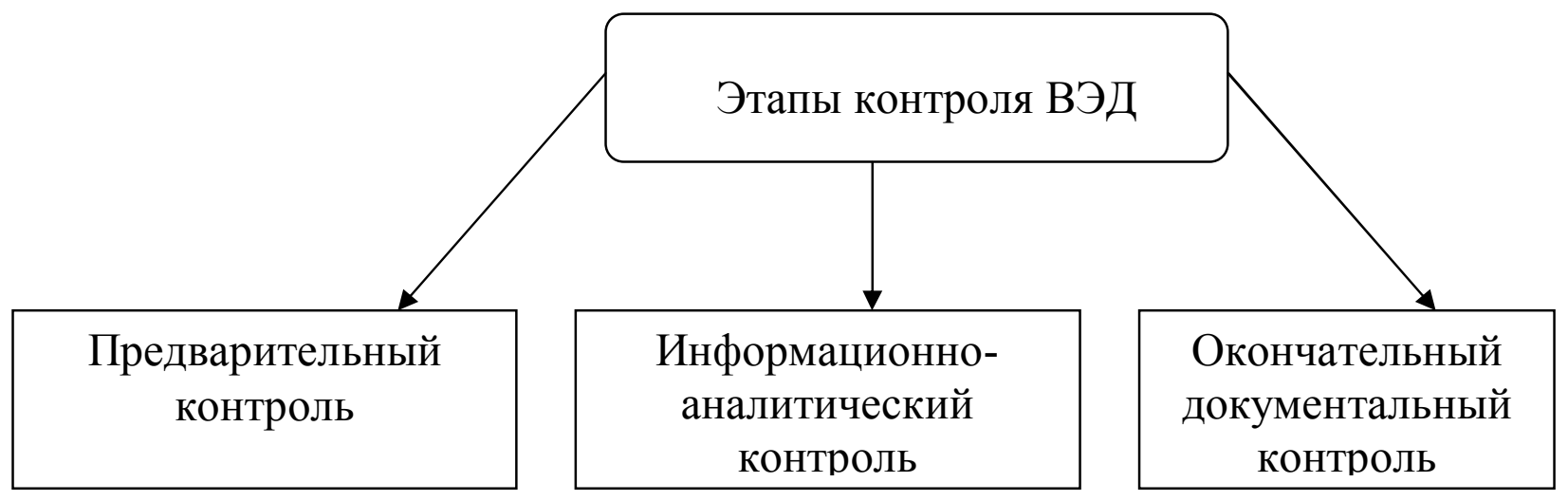

Рис. 2. Этапы контроля ВЭД

Предварительный контроль включает в себя определение правильного оформления паспорта сделки, Грузовой таможенной декларации / Транзитной

\footnotetext{
${ }^{1}$ Дополнена авторами
} 
декларации и достоверности содержащейся в них информации, а также контроль соответствия условий внешнеторговой деятельности действующему законодательству.

При информационно-аналитическом контроле изучается формирование учетных карточек валютного контроля, отслеживается их направление в уполномоченные банки для проведения работы по идентификации поступившей валютной выручки, проверяются получение и обработка учетных карточек, заполненных банком, сопоставление и анализ информации о фактически поступивших денежных средствах, a также выявленных нарушителях валютного и таможенного законодательства. В процессе информационно-аналитического контроля проверяется заполнение учетных карточек на основании таможенной декларации, в соответствии с которой было проведено таможенное оформление товара, и факт передачи этих карточек в уполномоченный банк. Учетные карточки, поступившие в банк, содержат информацию о стоимости товара и дате его вывоза за пределы Российской Федерации. После зачисления соответствующих валютных средств уполномоченный банк вносит в учетные карточки информацию о движении средств, которыми оплачивается данный товар.

При поступлении учетных карточек от уполномоченных банков в Главном научно-информационном вычислительном центре (ГНИВЦ) Федеральной таможенной службы Российской Федерации (ФТС России) по истечении 180 дней со дня экспорта товаров проводят их анализ. Учетные карточки, в которых содержится информация о не зачислении валютных средств от экспорта товаров, передаются в таможенный орган, в зоне деятельности которого зарегистрирован участник внешнеэкономической деятельности, предположительно не обеспечивший зачисление валютной выручки.

При окончательном документальном контроле таможенные органы проводят целевые проверки экспортеров по возможным фактам не поступления 
валютной выручки. В случае подтверждения таких фактов применяются санкции, установленные Таможенным кодексом Российской Федерации.

Технологически схема валютного контроля базируется на возможностях уполномоченных банков и таможенных органов, осуществляющих функции агентов валютного контроля в период таможенного оформления товаров и проведения банковских операций. В рамках автоматизированной информационной системы ведутся анализ и сопоставление этих двух информационных потоков.

Таким образом, таможенные органы работают в непосредственном контакте с уполномоченными банками, отслеживая своевременность поступления валютной выручки в Российскую Федерацию. Объектом валютного контроля является организация-экспортер, которая также имеет всю информацию о совершаемых операциях.

В основу применения интеграционного метода аудита положено наличие единой информации о внешнеэкономических сделках не только в организации, но и в уполномоченном банке. Если сравнить источники информации для аудита ВЭД организации и аудита ВЭД банка, как участника ВЭД, так как банк обязан не только обслуживать организации, но и выполнять функции агента валютного контроля, то можно увидеть, что это одинаковые по назначению и форме документы. Наличие таких документов свидетельствует о соблюдении методологии учета и контроля, т.е. о применении метода дублирования документов и, следовательно, о наличии одинаковых экземпляров в нескольких контролирующих органах.

\section{Контрольные вопросы}

1. Назовите основные цели регулирования ВЭД.

2. Каковы основные принципы государственного регулирования ВЭД в РФ?

3. Что представляют собой протекционистские и либерализационные, административные и экономические методы?

4. Посредством каких инструментов осуществляется регулирование внешнеторговой деятельности согласно Закону РФ «Об основах 
государственного регулирования внешнеторговой деятельности»?

5. Что лежит в основе таможенно - тарифного регулирования внешнеэкономической деятельности?

6. Что такое таможенный тариф? Назовите его элементы. Что такое таможенная пошлина и в чем ее принципиальное отличие от иных видов таможенных платежей?

7. Какие бывают виды ставок таможенных пошлин и кто определяет размеры этих ставок?

8. Что представляют собой сезонные и особые пошлины? Каков механизм установления и взимания этих пошлин?

9. Какие виды таможенных пошлин применяются в России? Как зависит размер ставки ввозной пошлины от страны происхождения товара?

10. Что представляет собой специальная защитная мера?

11. Когда может быть применена к товару антидемпинговая мера?

12. «Тарифные льготы», «тарифные преференции» - это одно и то же? Если нет, то охарактеризовать каждое понятие и показать в чем их различие.

13. Кто утверждает ТН ВЭД?

14. Для чего применяется ТН ВЭД?

15. Кто принимает решение о классификации отдельных видов товаров и обеспечивает опубликование указанных решений?

16. Каков порядок принятия предварительного решения о классификации товаров таможенными органами? Какое значение имеет это предварительное решение для участников ВЭД?

17. Когда товары подлежат классификации?

18. Что понимается под таможенной стоимостью?

19. Как построена методика определения таможенной стоимости в отношении ввозимых в Россию товаров?

20. Кто устанавливает порядок определения таможенной стоимости вывозимых товаров?

21.Для каких целей используется таможенная стоимость? 
22.Какова общая структура и основные элементы таможенной стоимости?

23.Какова последовательность применения методов определения таможенной стоимости ввозимых товаров? Дать общую характеристику этих методов.

24.Дать характеристику определения таможенной стоимости товара по стоимости сделки с ввозимыми товарами.

25.Каковы условия применения метода 1 определения таможенной стоимости (по стоимости сделки)?

26.Каковы обстоятельства, исключающие возможность определения таможенной стоимости по стоимости сделки (метод 1)?

27. Как определяется таможенная стоимость вывозимых товаров?

28. Каков порядок заявления таможенной стоимости товаров?

29. Что представляет собой декларация таможенной стоимости (ДТС)?

30. Когда применяются формы ДТС-1 и ДТС-2?

31.Какие документы должен представить декларант для подтверждения заявленных сведений по таможенной стоимости?

32. В каких случаях декларация таможенной стоимости не заполняется?

33.Каковы сущность и назначение корректировки таможенной стоимости товаров?

34.Назовите случаи корректировки таможенной стоимости.

35.Какой существует порядок корректировки таможенной стоимости?

36.Когда используются формы корректировки таможенной стоимости КТС-1 и КТС-2?

37.Перечислить виды таможенных платежей.

38.В каком случае таможенные пошлины, налоги не уплачиваются?

39.Кем исчисляются таможенные пошлины, налоги?

40.Какие ставки применяются для целей исчисления таможенных пошлин, налогов?

41.Что представляют собой авансовые платежи?

42. Каков порядок уплаты таможенных платежей? 
43. В какой форме производится изменение срока уплаты таможенных пошлин, налогов?

44. При каком условии предоставляется отсрочка или рассрочка уплаты таможенных пошлин, налогов?

45. На какой срок предоставляется отсрочка или рассрочка уплаты таможенных пошлин, налогов?

46. Осуществление каких видов деятельности в области таможенного дела обусловлено обеспечением уплаты таможенных платежей?

47. Какие известны способы обеспечения уплаты таможенных платежей?

48. Какие ставки НДС применяются при ввозе товаров?

49. Как определяется налоговая база для начисления НДС по ввозимым товарам?

50. Как рассчитывается сумма таможенных сборов за таможенное оформление товаров?

51. Каков порядок определения налоговой базы по подакцизным товарам?

52. Какие товары освобождаются от НДС при ввозе на таможенную территорию РФ?

53. Назовите органы, осуществляющие контроль ВЭД.

54. Охарактеризуйте виды государственного контроля ВЭД.

55. Какие этапы включает контроль ВЭД? Дайте характеристику каждого этапа.

\section{Примеры решения задач}

\section{Пример 1.}

В соответствии с заключенным внешнеторговым контрактом российская организация ЗАО «Мальвина», осуществляющая свою деятельность в г. Курган, приобретает у французской фирмы Textile на условии поставки FCA - Лион (Франция) партию шелковых тканей, классифицируемых согласно Товарной номенклатуре внешнеэкономической деятельности (ТН ВЭД) по коду 5007905000. 
Контрактная стоимость данной партии ткани составила 450000 евро. Предположим, что импорт осуществляется без участия посредника. Доставка из Лиона до Москвы осуществляется воздушным транспортом, в соответствии с договором между ЗАО «Мальвина» и авиакомпанией стоимость данной перевозки составляет 750000 руб. Кроме того, ЗАО «Мальвина» за свой счет оплачивает расходы по страхованию груза в пути в размере 3000 евро. Расходы по доставке тканей в аэропорт Лиона были оплачены французским поставщиком (и включены в цену товара). Расходы на доставку тканей из Москвы в Курган железнодорожным транспортом составили 70800 руб., в т.ч. НДС 10800 руб., а расходы на доставку тканей с вокзала в г. Кургане на склад ЗАО «Мальвина» собственным транспортом составили 12000 руб. Предположим, что курс евро, установленный ЦБ РФ, на дату подачи таможенной декларации (и ее принятия таможенным органом) составляет 34,20 руб. В соответствии с действующим законодательством таможенная стоимость импортируемых шелковых тканей определяется следующим образом: 450000 евро + 3000 евро + (750 000 руб. : 34,2 руб./евро $) \approx 474929,82$ евро.

А в рублевом эквиваленте таможенная стоимость импортируемых товаров составляет:

474929,82 евро $\times 34,20$ руб./евро $=16242600$ руб. или $(450000$ евро + 3000 евро $) \times 34,20$ руб./евро +750000 руб. $=453000$ евро $\times 34,20$ руб./евро + 750000 руб. $=16242600$ руб.

\section{Пример 2.}

Продолжим рассматривать пример 1. Поскольку таможенная стоимость импортируемых тканей составила 16242600 рублей - т.е. более 10000 000,01 руб., но не выше 30000 000,00 руб. - таможенный сбор за их таможенное оформление составит 50000 рублей (таблица 1).

\section{Пример 3.}

Продолжим рассматривать примеры 1 и 2.

Шелковые ткани, классифицируемые по ТН ВЭД по коду 500790500 0, включены в раздел XI ( группа 50 ) Таможенного тарифа РФ, и ставка 
таможенных пошлин по ним составляет 5\% от таможенной стоимости.

Следовательно, сумма таможенной пошлины по ввозимым шелковым тканям составляет: 474 929,82 евро $\times 0,05=23$ 746,49 евро.

В рублевом эквиваленте на день подачи таможенной декларации таможенная пошлина составит:

23746,49 евро $\times 34,20$ руб./евро $\approx 812130$ руб.

или 16242600 руб. $\times 0,05=812130$ руб.

В отношении некоторых товаров установлены специфические пошлины в фиксированной сумме в евро в расчете на физическую единицу измерения ввозимого товара (на штуку, на тысячу штук, на квадратный или кубический метр, на килограмм и т.д.).

\section{Пример 4.}

$\mathrm{OAO}$ «Делия» заключило импортный контракт с немецкой фирмой Bier на приобретение партии пива солодового в бутылках 0,5 литра в количестве 50000 бутылок (т.е. 25000 литров). Контрактная стоимость товара на условии СІР - Санкт-Петербург составила 22000 евро.

Ставка таможенной пошлины в соответствии с Таможенным тарифом на пиво солодовое (код по ТН ВЭД 220300 0000) составляет 0,6 евро за литр. Следовательно, сумма таможенной пошлины в евро составляет:

25000 л $\times 0,6$ евро/литр $=15000$ евро.

Если курс евро, установленный ЦБ РФ на дату подачи и принятия таможенным органом таможенной декларации, составлял 33,95 руб. за евро, сумма таможенной пошлины в рублях составит:

15000 евро $\times 33,95$ руб./евро $=509250$ руб.

В некоторых случаях устанавливается комбинированный порядок расчета пошлины - «столько-то процентов, но не менее такой-то суммы за единицу». В этом случае следует произвести расчет и по адвалорной, и по специфической ставке, и уплатить ту сумму, которая окажется больше.

\section{Пример 5.}

ЗАО «Мираж» заключило импортный контракт с испанской фирмой Reloj 
на приобретение партии наручных часов, относящихся к позиции 9101 ТН ВЭД в количестве 1000 шт.

Рассмотрим два варианта:

1) контрактная стоимость товара на условии СІР-Москва составила 28000 евро;

2) контрактная стоимость товара на условии СІР-Москва составила 40000 евро.

Ставка таможенной пошлины на часы позиции 9101 ТН ВЭД в соответствии с Таможенным тарифом составляет 20\% таможенной стоимости, но не менее 6 евро за 1 шт.

Сумма таможенной пошлины, исчисленная по адвалорной ставке $(20 \%$ от таможенной стоимости), составляет:

- при первом варианте:

28000 евро $\times 0,2=5600$ евро;

- при втором варианте:

40000 евро $\times 0,2=8000$ евро.

Сумма таможенной пошлины, исчисленная по твердой (специфической) ставке 6 евро за шт., составляет:

1000 шт. $\times 6$ евро $=6000$ евро.

Предположим, что курс евро, установленный ЦБ РФ на дату подачи и принятия таможенным органом таможенной декларации, составлял 34,10 руб. за евро.

Таким образом, ЗАО «Мираж» должно уплатить таможенную пошлину в размере:

- при первом варианте - 6000 евро, или $6000 \times 34,10=204600$ руб.;

- при втором варианте - 8000 евро, или $8000 \times 34,10=272800$ руб.

\section{Задачи для самостоятельного решения}

Задача 1. Декларируется ввозимый на таможенную территорию РФ товар - яблочное пюре: код товара по ТН ВЭД России - 2007995500; таможенная стоимость товара - 2000 долл. США; ставка ввозной таможенной пошлины - 
10\%; страна происхождения - Италия; к товарам, происходящим из Италии, применяется режим наиболее благоприятствуемой нации. Исчислить ввозную таможенную пошлину.

Задача 2. Декларируется ввозимый на таможенную территорию РФ товар - вода минеральная: код товара по ТН ВЭД России - 2202100000; таможенная стоимость товара - 1500 долл. США; ставка ввозной таможенной пошлины $15 \%$, но не менее 0,03 евро за 1 литр; количество товара - 1000 литров; курс валюты, в которой указана таможенная стоимость товара, - 30 руб. за 1 долл. США; курс евро - 40 руб. за 1 евро; страна происхождения - Германия; к товарам, происходящим из Германии, применяется режим наиболее благоприятствуемой нации. Исчислить ввозную комбинированную таможенную пошлину.

Задача 3. В Россию из Англии ввозится партия чая, таможенная стоимость которой составила 10000 долл. Ставка ввозной таможенной пошлины - 5\%. Исчислить размер импортной таможенной пошлины в следующих случаях:

a) декларант представляет сертификат о происхождении товара, в котором в качестве страны происхождения определена Великобритания. К товарам, происходящим из Великобритании, применяется режим наиболее благоприятствуемой нации;

б) страной происхождения этой партии является Пакистан и декларантом предъявлен сертификат по форме “А” (Пакистан входит в перечень стран-пользователей схемой преференций РФ);

г) декларант не сможет подтвердить происхождение товара путем представления соответствующего сертификата;

д) страной происхождения этой партии является Судан, который входит в список наименее развитых стран. 
Задача 4. На таможенную территорию России поставляются электротехнические изделия из Гамбурга в Санкт-Петербург. Размер партии 300 шт. Цена сделки - 50 долл. за одно изделие. Условия поставки:

- поставка осуществляется морским транспортом по договору купли-продажи на базисных условиях поставки EXW (с завода) в Гамбург;

- подготовка и упаковка товара для отправки на заводе-изготовителе- 230 долл.;

- погрузка товара на транспортное средство покупателя -180 долл.;

- доставка товара в порт отправления - 150 долл.;

- расходы по транспортировке из Гамбурга в Санкт-Петербург (фрахт)-330 долл;

- страхование товара в пути - 46 долл.;

- в Германии была проведена работа по изготовлению чертежей изделий на сумму 700 долл., аналогичная работа была проведена в России на сумму 1000 долл.; - стороны заключают договор впервые.

Рассчитать таможенную стоимость партии электротехнических изделий.

Задача 5. Из Лондона в Москву самолетом доставлена партия текстиля весом 1024 кг в соответствии с договором купли-продажи. Договор был подписан на условиях FCA. Цена товара - 10 ф.ст. за 1 кг. Транспортные издержки: упаковка - 12 ф.ст., доставка в аэропорт отправления - 15 ф.ст., перевозка от аэропорта отправления до порта назначения - 725 ф.ст., вывоз из аэропорта назначения - 90 ф.ст., страхование - 14 ф.ст.

Определить таможенную стоимость партии текстильных изделий.

Задача 6. По договору купли-продажи морем на условиях CIF из Гамбурга в Архангельск поставлена партия трикотажных изделий весом - 5000 кг. Цена товара - 90 долл. США за 1 кг. Транспортные издержки: упаковка 160 долл., доставка в порт отправления - 150 долл., перевозка из порта отправления в порт назначения - 130 долл., вывоз из порта назначения -14 долл., страхование - 46 долл.

Определить таможенную стоимость партии трикотажных изделий. 


\section{Контрольные тесты}

1. Ставки таможенных пошлин, исчисляемые в процентах к таможенной стоимости облагаемых товаров, именуются как:

а) специфические;

б) адвалорные;

в) комбинированные;

г) базовые.

2. Кто вправе устанавливать и изменять размеры ставок таможенных пошлин в Российской Федерации:

а) Государственная Дума РФ;

б) Совет Федерации РФ по представлению Государственной Думы РФ;

в) Президент РФ;

г) Правительство РФ;

д) Федеральная таможенная служба.

3. Мера по ограничению возросшего импорта на таможенную территорию РФ - это:

а) антидемпинговая мера;

б) компенсационная мера;

в) специальная защитная мера;

г) специальная пошлина;

4. Где указывается размер таможенной пошлины?

a) В таможенной декларации либо ином соответствующем документе, необходимом для таможенных целей, а также в платежных документах.

б) В таможенном тарифе РФ.

в) В законе РФ “О таможенном тарифе”.

5. Систематизированный перечень товаров с указанием ставок таможенных пошлин, взимаемых при перемещении товаров через таможенную границу,-это:
а) таможенные пошлины;
б) вид таможенного тарифа;
в) таможенный тариф;
г) тарифные методы регулирования внешней торговли. 
6. Классификация перемещаемых через таможенную границу РФ товаров в соответствии с ТН ВЭД:

a) это исключительная компетенция таможенных органов, только они должны ее осуществлять;

б) это прерогатива декларанта;

в) может проводиться декларантом самостоятельно, но впоследствии изменена таможенным органом;

г) может быть осуществлена как таможенными, так и иными государственными органами и учреждениями, что впоследствии будет (должно быть) использовано в таможенных целях.

7. Налоговая база при исчислении НДС по ввозимым товарам включает:

а) таможенный сбор за таможенное оформление;

б) таможенную стоимость товара;

в) акциз по подакцизным товарам;

г) таможенную пошлину;

д) всё вышеперечисленное.

8. Если в отношении подакцизных товаров установлены адвалорные (т.е. в процентах) ставки акцизов, то налоговая база определяется как:

а) таможенная стоимость товаров;

б) сумма таможенной стоимости товаров и НДС;

в) сумма таможенной стоимости товаров и таможенного сбора за таможенное оформление;

г) сумма таможенной стоимости товаров и таможенной пошлины.

9. Как называются размеры ставок таможенных пошлин, предусмотренные таможенным тарифом?

а) Базовые.

б) Предельные.

в) Фиксированные.

г) Максимальные. 
10.Что из ниже перечисленного в силу закона не может рассматриваться как тарифная льгота:
а) возврат ранее уплаченной таможенной пошлины;
б) освобождение от уплаты таможенной пошлины;
в) снижение ставки таможенной пошлины;
г) лицензирование.

11. С какой целью необходимо устанавливать страну происхождения товаров при взимании таможенных платежей?

a) С целью предоставления таможенных льгот.

б) С целью проверки качества и безопасности товара.

в) С целью статистики торговли с зарубежными странами.

г) С целью установления квоты.

12. Пересчет иностранной валюты в валюту РФ для целей исчисления таможенных пошлин, налогов производится:

а) по курсу ЦБ РФ, действующему на день принятия таможенным органом таможенной декларации;

б) по курсу ЦБ РФ, действующему на день фактической уплаты таможенных платежей;

в) пересчет вообще не производится, а все расчеты ведутся в иностранной валюте;

г) по курсу ЦБ РФ, действующему на день заключения сделки.

13. Подлежащие к уплате таможенные пошлины, налоги при ввозе товаров должны быть уплачены:

а) в течение трех банковских дней с момента фактического представления товаров таможенному органу;

б) не позднее 15 дней со дня предъявления товаров в таможенный орган;

в) не позднее трех банковских дней с даты принятия таможенной декларации таможенным органом,

г) не позднее 10 дней со дня предъявления товаров в таможенный орган. 


\section{Глава 3. Понятие, цели и задачи аудита внешнеэкономической деятельности 3.1.Понятие, цели, задачи и последовательность аудита внешнеэкономической деятельности}

Внешнеэкономическая деятельность играет значительную роль в развитии экономики страны и предприятий. Ввоз импортной и экспорт отечественной продукции способствует развитию конкуренции среди отечественных производителей, интеграции импорта и экспорта в промышленное производство страны и должен обеспечивать рост доходов от проводимых сделок. Либерализация внешнеэкономической деятельности России дала возможность выхода на внешнеэкономический рынок большого числа отечественных предприятий, что, безусловно, является положительным моментом проведения экономических реформ. Однако эта либерализация имеет как позитивные, так и негативные последствия, причем как на макроэкономическом уровне (утечка капитала, усиление инфляции, подавление ряда отраслей отечественного производства и т.п.), так и на микроуровне. В первую очередь это связано с подверженностью организаций - импортеров рискам: коммерческому, финансовому, валютному, риску неэффективности сделки, а также риску искажения данных бухгалтерского учета, поскольку импортная операция имеет ряд специфических, присущих только ей особенностей, касающихся характера проведения, что существенно ее усложняет и выделяет из ряда хозяйственных операций.

В соответствии с Федеральным законом «Об аудиторской деятельности» №307 - Ф3 аудиторская деятельность - деятельность по проведению аудита и оказанию сопутствующих аудиту услуг, осуществляемая аудиторскими организациями, индивидуальными аудиторами.

При этом аудит - независимая проверка бухгалтерской (финансовой) отчетности аудируемого лица в целях выражения мнения о достоверности такой отчетности.

Слово "аудит" происходит от латинского "audio", что означает - "он 
слышит", "слушатель". Это подчеркивает особую доверительность во взаимоотношениях аудитора со своими клиентами и означает, внимательность, доброжелательность, участливость, заинтересованность в делах клиента, обратившегося за услугами к аудитору.

Аудит внешнеэкономической деятельности представляет собой независимую проверку бухгалтерской (финансовой) отчетности организации, занимающейся внешнеэкономической деятельностью с целью выражения независимого мнения о достоверности отражения в ней операций, связанных с исполнением операций ВЭД, во всех существенных аспектах.

Целью проведения аудиторской проверки внешнеэкономической деятельности предприятия является установление правильности отображения операций по покупке - продаже валюты, выполнению условий контрактов, экспортно - импортных операций в бухгалтерском учете и финансовой отчетности предприятия на основании предоставленных финансовых и налоговых отчетов, данных аналитического и синтетического учета, первичных документов. Соответствия этих документов действующему законодательству и нормативам по внешнеэкономической деятельности, обоснованность проведения таких операций, правильность определения финансовых результатов.

Задачей аудитора является проверка состояния финансово - хозяйственной деятельности организации, занимающейся внешнеэкономической деятельностью, организации бухгалтерского учета на предприятии и достоверности составления отчетности за определенный период, сформулировать объективные выводы, дать необходимые рекомендации.

В большинстве источников по практическому аудиту нет однозначного подхода к данному объекту аудиторской проверки. Как правило, при этом рассматриваются вопросы бухгалтерского учета, а применяемые методики не обеспечивают комплексного подхода к использованию не только внутрихозяйственного, но также таможенного и валютного учета как источника информации для аудиторских доказательств. 
При этом задачи аудита внешнеэкономической деятельности организации можно представить с помощью рисунка 3.

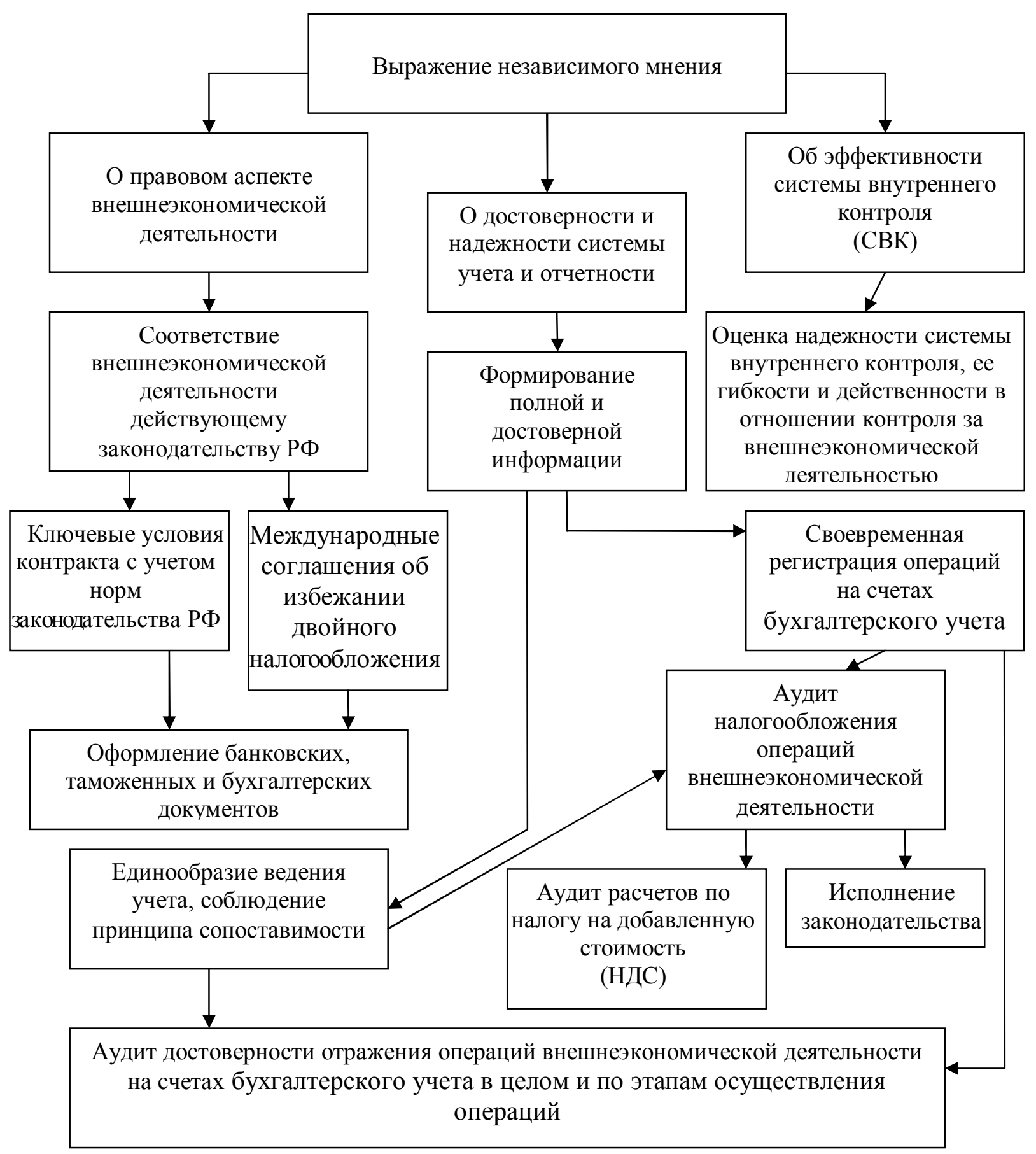

Рис. 3. Задачи аудита ВЭД ${ }^{2}$

Кроме того, при проведении аудиторских проверок импортных и экспортных операций необходимо проверять законность осуществления этих операций. Возникает ситуация, когда при организации и ведении бухгалтерского учета по обычным, отработанным на операциях внутреннего

\footnotetext{
${ }^{2}$ Составлена авторами
} 
рынка схемам возникает риск нарушения законодательства и искажения бухгалтерской отчетности, о чем лица, ответственные за финансовохозяйственную деятельность, могут не подозревать и систематически совершать непреднамеренные ошибки. А расплата за такие ошибки при обнаружении их правоохранительными органами бывает порой неадекватна их значимости в хозяйственной деятельности организации.

Таким образом, проверка законности проведения отдельных хозяйственных операций может проводиться как часть плана аудита годовой отчетности, так и в качестве отдельной, так называемой тематической аудиторской проверки.

Общую классификацию аудита внешнеэкономической деятельности можно представить с помощью рисунка 4.

В основу общей классификации аудита внешнеэкономической деятельности могут быть положены признаки: статус аудитора, принцип инициативы, объект изучения, периодичность осуществления и применяемые методы.

Таким образом, как показывает рисунок 4, аудит внешнеэкономической деятельности с точки зрения статуса аудитора подразделяется на внешний и внутренний.

Внешний аудит имеют право проводить внешние аудиторы, имеющие право на осуществление аудиторских проверок в организациях. Они имеют право согласно условиям договора самостоятельно определять форму и методы аудиторских проверок, иметь доступ к любой документации, относящейся к проверяемому объекту аудита, а также получать по ходу проверки любые разъяснения как в устной, так и в письменной форме от сотрудников и руководства организации. В то же время аудитор обязан тщательно проверять соответствие и достоверность собранной учетной информации первичным документам, действующим требованиям как с точки зрения законодательства, так и арифметически, представить аудиторское заключение, сгруппировать выявленные отклонения, нарушения и ошибки, обсудить их с руководством и собственниками организации, сохранять конфиденциальность сведений о 
состоянии и положении дел организации, полученные в результате проверки.

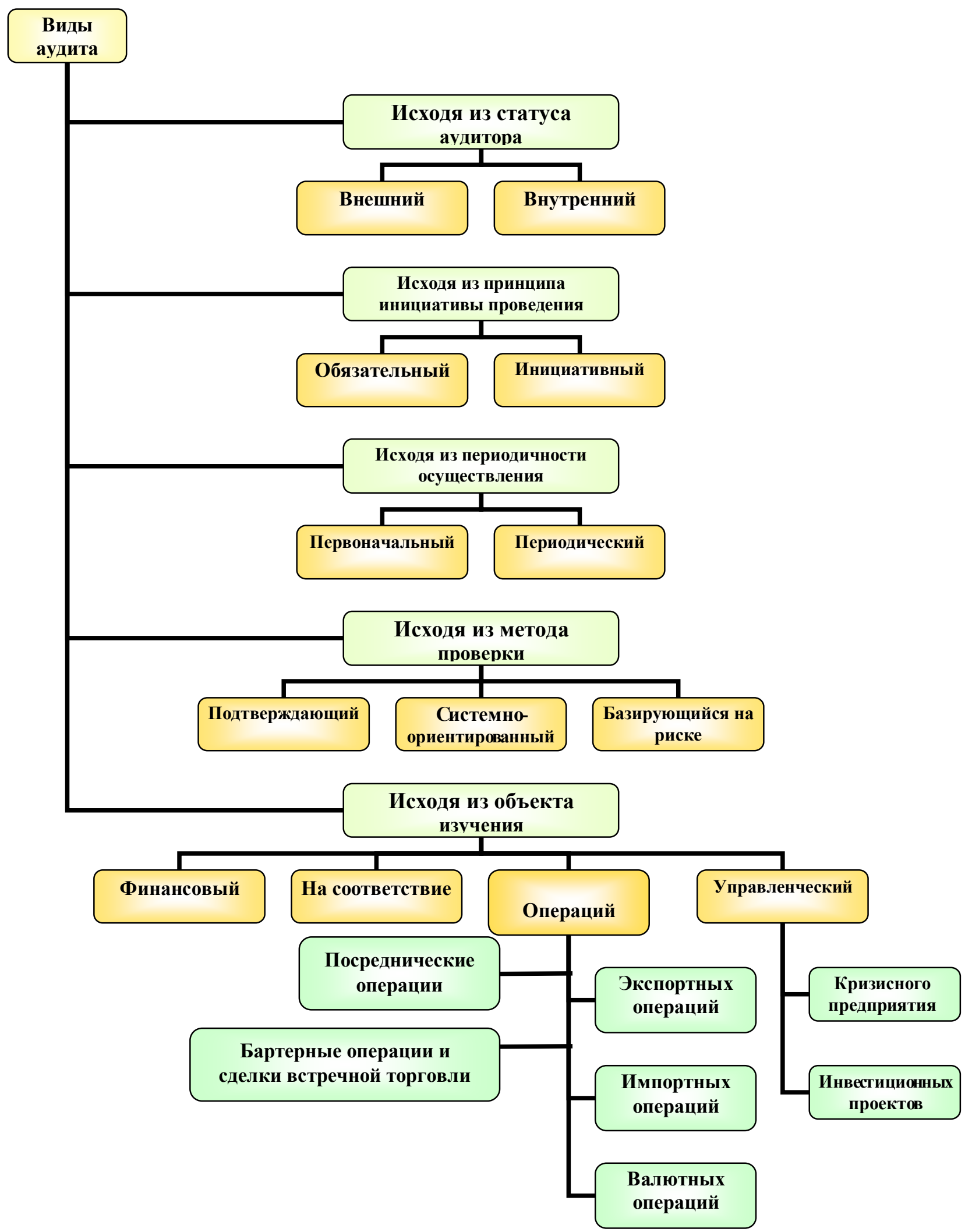

Рис. 4. Общая классификация аудита внешнеэкономической деятельности ${ }^{3}$

\footnotetext{
${ }^{3}$ Дополнена авторами
} 
Стоит отметить, что отчетность организации подлежит ежегодной обязательной внешней проверке аудиторской организацией, имеющей в соответствии с законодательством Российской Федерации право на осуществление таких проверок. При этом аудиторская организация обязана составлять заключение о результатах аудиторской проверки, содержащее сведения о достоверности финансовой отчетности организации, качестве управления организацией, состоянии внутреннего контроля и другие положения, определяемые федеральными законами и уставом организации, занимающейся внешнеэкономической деятельностью [29].

Заключение по аудиторской проверке может безоговорочно подтверждать достоверность отчетности или содержать какие-либо оговорки (модифицированное аудиторское заключение).

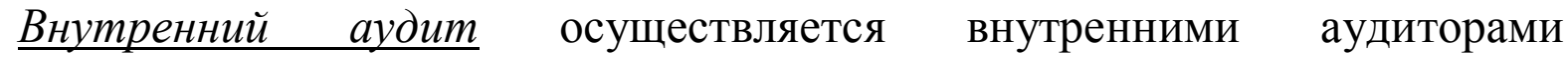
организации, деятельность которых направлена на организацию и осуществление постоянного контроля за соблюдением правил бухгалтерского учета и законодательных актов.

С точки зрения инициативности проведения аудиторской проверки различают обязательный и инициативный аудит.

Обязательныц̆ aydum - ежегодная обязательная аудиторская проверка ведения бухгалтерского учета и финансовой (бухгалтерской) отчетности организации.

В соответствии с Федеральный закон "Об аудиторской деятельности" № 307-Ф3 от 30 декабря 2008 года обязательный аудит осуществляется в случаях, если [1]:

1) организация имеет организационно-правовую форму открытого акционерного общества;

2) организация является кредитной организацией, бюро кредитных историй, страховой организацией, обществом взаимного страхования, товарной или фондовой биржей, инвестиционным фондом, государственным внебюджетным фондом, фондом, источниками 
образования средств которого являются добровольные отчисления физических и юридических лиц;

3) объем выручки от продажи продукции (выполнения работ, оказания услуг) организации (за исключением сельскохозяйственных кооперативов и союзов этих кооперативов) за предшествовавший отчетному год превышает 50 миллионов рублей или сумма активов бухгалтерского баланса по состоянию на конец года, предшествовавшего отчетному, превышает 20 миллионов рублей. Для муниципальных унитарных предприятий законом субъекта Российской Федерации финансовые показатели могут быть снижены;

4) в иных случаях, установленных федеральными законами.

Обязательный аудит проводится аудиторскими организациями ежегодно, при этом при проведении обязательного аудита в организациях, в уставных (складочных) капиталах которых доля государственной собственности или собственности субъекта Российской Федерации составляет не менее 25 процентов, заключение договоров оказания аудиторских услуг должно осуществляться по итогам проведения открытого конкурса. Порядок проведения таких конкурсов утверждается Правительством Российской Федерации, если иное не установлено федеральным законом.

Следует отметить, что при проведении обязательного аудита аудиторские организации обязаны страховать риск ответственности за нарушение договора [31].

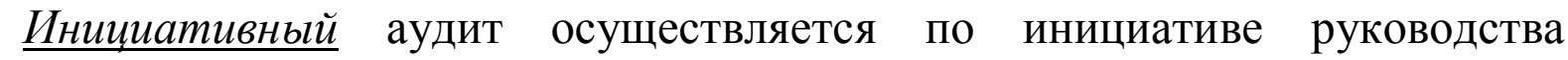
организации, ее наиболее крупных клиентов или собственников, а также контролирующих органов.

Инициативный аудит проводится с целью выявления недостатков в ведении бухгалтерского учета, составлении отчетности, налогообложении, проведении анализа финансового состояния организации, занимающейся внешнеэкономической деятельностью, оказания ей помощи в организации учета и составления отчетности.

С точки зрения объекта изучения различают финансовый аудит, аудит 
операций, управленческий аудит и аудит на соответствие.

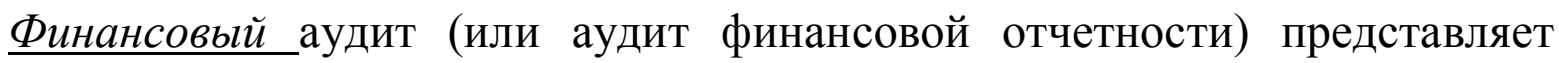
собой оценку достоверности финансовой информации [31].

В качестве критерия оценки информации обычно берут общепринятые принципы бухгалтерского учета, а финансовый контроль чаще всего проводится независимыми аудиторами, результатом работы которых является заключение относительно финансовой отчетности организаций, используемое в дальнейшем различными группами пользователей финансовой информации.

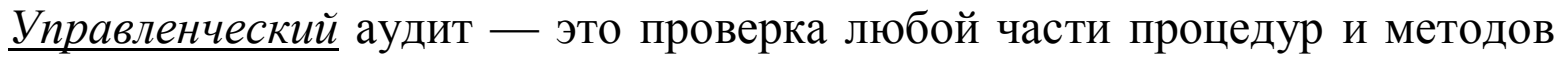
функционирования организации для оценки производительности и эффективности. Иногда его называют еще аудитом результатов или операционным аудитом.

Задача такого аудита состоит во всестороннем анализе экономики организации или определенного вида ее деятельности.

Такой аудит проводится внутренними аудиторами или аудиторскими фирмами. При этом проверка не ограничивается бухгалтерским учетом, а включает также изучение организационной структуры, методов деятельности, инвестиционной и маркетинговой политики, целевых программ и др. При этом среди задач аудита целевых программ можно выделить:

• определение степени достижения запланированных показателей;

• анализ эффективности работы организации;

• проверку соблюдения требований законодательства и других нормативных актов.

По результатам управленческого аудита администрации выдаются рекомендации по совершенствованию операций. Иногда такой аудит называют аудитом эффективности работы организации или деятельности администрации.

Аудит на соответствие определяет, соблюдаются ли в организации те конкретные правила, нормы, законы, инструкции, пункты договоров, которые оказывают воздействие на результаты деятельности или отчеты, а также те 
специфические требования, которые предписаны персоналу администрацией.

В ходе проверки на соответствие устанавливается, соответствует ли деятельность организации ее уставу, правильно ли начисляются средства на оплату труда и другие выплаты работникам, обоснованно ли производится списание расходов на себестоимость экспортируемых товаров, работ и услуг, а также на финансовые результаты и др.

Проверки на соответствие требуют установления соответствующих критериев для оценки финансовой отчетности.

Если учетная политика организации, договоры, инструкции или правила имеют прямое и материальное влияние на его бухгалтерскую (финансовую) отчетность, то проверка на соответствие обычно составляет неотделимую часть проверки бухгалтерской (финансовой) отчетности.

Аудит на соответствие принятым требованиям проводится для установления:

• соответствия бухгалтерской отчетности принципам бухгалтерского учета;

• соответствия действий налогоплательщиков требованиям налогового законодательства;

• соответствия деятельности организаций установленным вышестоящими органами предписаниям;

- соответствия действий внутренних подразделений организации требованиям и правилам, закрепленным распоряжениями администрации.

Заказчиками аудита этого вида могут быть администрация организации, правительство, налоговые органы, а исполнителями - внутренние аудиторы или аудиторские фирмы.

В зависимости от поставленных целей аудит на соответствие:

• может проводиться как внутренними, так и внешними аудиторами;

- предполагает предоставление его результатов как для внешних, так и для внутренних пользователей.

Аудит операщий представляет собой проверку уставной деятельности организации, занимающейся внешнеэкономической деятельностью. 
Задача такого аудита состоит в подтверждении достоверности отчетности, составляемой организацией по видам внешнеэкономической деятельности и их соответствии требованиям законодательства.

Аудит операций в организациях, осуществляющих внешнеэкономическую деятельность, включает аудит экспортных, импортных, валютных, посреднических, бартерных операций и сделок встречной торговли.

По периодичности осуществления аудиторских проверок различают первоначальный и периодический аудит.

Первоначальныцй аудит означает проведение проверки в данной организации впервые.

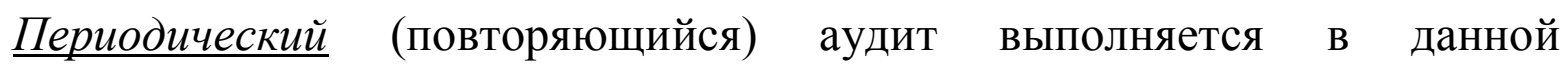
организации при повторном заключении договора с аудитором.

В результате установления длительного взаимовыгодного сотрудничества между аудитором и клиентом повышается качество проверок, появляется возможность на основе глубокого изучения особенностей финансово-хозяйственной деятельности организации дать объективную оценку его экономических показателей, сформулировать предложения по их улучшению.

Кроме того, в мировой практике, исходя из метода проверки, выделяют подтверждающий аудит, системно-ориентированный аудит и аудит, базирующийся на риске.

Подтверждающий аудит подразумевает изучение и подтверждение совершенных организацией операций, оценку достоверности бухгалтерских документов и отчетности.

При проведении подтверждающего аудита аудитор проверяет и подтверждает практически каждую совершенную операцию и параллельно с бухгалтером создает собственные учетные регистры [31].

Системно-ориентированный аудит предполагает проведение экспертизы объектов проверки с учетом оценки состояния и эффективности системы внутреннего контроля. 
Если система внутреннего контроля в организации организована достаточно эффективно, то внешние аудиторы могут ограничить свою работу выборочными проверками и тестированием отдельных объектов контроля. Это также позволяет сократить время и затраты на аудит.

Аудит, базирующийся на риске, означает концентрацию усилий аудитора в ходе проверки преимущественно на областях и объектах контроля, где риски (типичные ошибки, пропуски и т. п.) выше, и сокращено время на изучение тех объектов контроля, где предполагается отсутствие риска или низкий риск. В результате обеспечивается более эффективное оказание аудиторских услуг с меньшими затратами для клиента.

Следует отметить, что важным методологическим принципом аудита является его планирование. Планирование аудита совершается на основании Федеральных правил (стандартов) аудиторской деятельности № 3 «Планирование аудита», № 4 «Существенность в аудите», № 8 «Оценка аудиторских рисков и внутренний контроль, осуществляемый аудируемым лицом», № 15 «Понимание деятельности аудируемого лица», других нормативных и законодательных актов.

Существует несколько подходов к определению последовательности проведения аудита внешнеэкономической деятельности, которые можно представить с помощью рисунка 5.

На практике наиболее частое применение находит смешанный подход, в соответствии с которым проверку целесообразно начинать с ознакомления с данными бухгалтерской отчетности для выявления и группировки статей по их значимости, то есть использовать дезагрегированный подход. Затем при наличии различных внешнеторговых контрактов определяются статьи бухгалтерского баланса, на которых должны быть отражены экспортные и импортные ценности, то есть аудитор должен определить группу соответствующих статей в бухгалтерском балансе, а затем перейти к детализации счетов, выделив из них импортные и экспортные материальные и нематериальные ценности. Далее необходимо перейти к рассмотрению 
особенностей внешнеэкономических операций в целом как к отдельному объекту аудита с учетом специфики данного рода сделки, где присутствуют как однотипные, часто повторяющиеся операции, которые можно проверить по циклам, так и разовые, но имеющие существенное значение операции, которые целесообразно проверять по объектам.

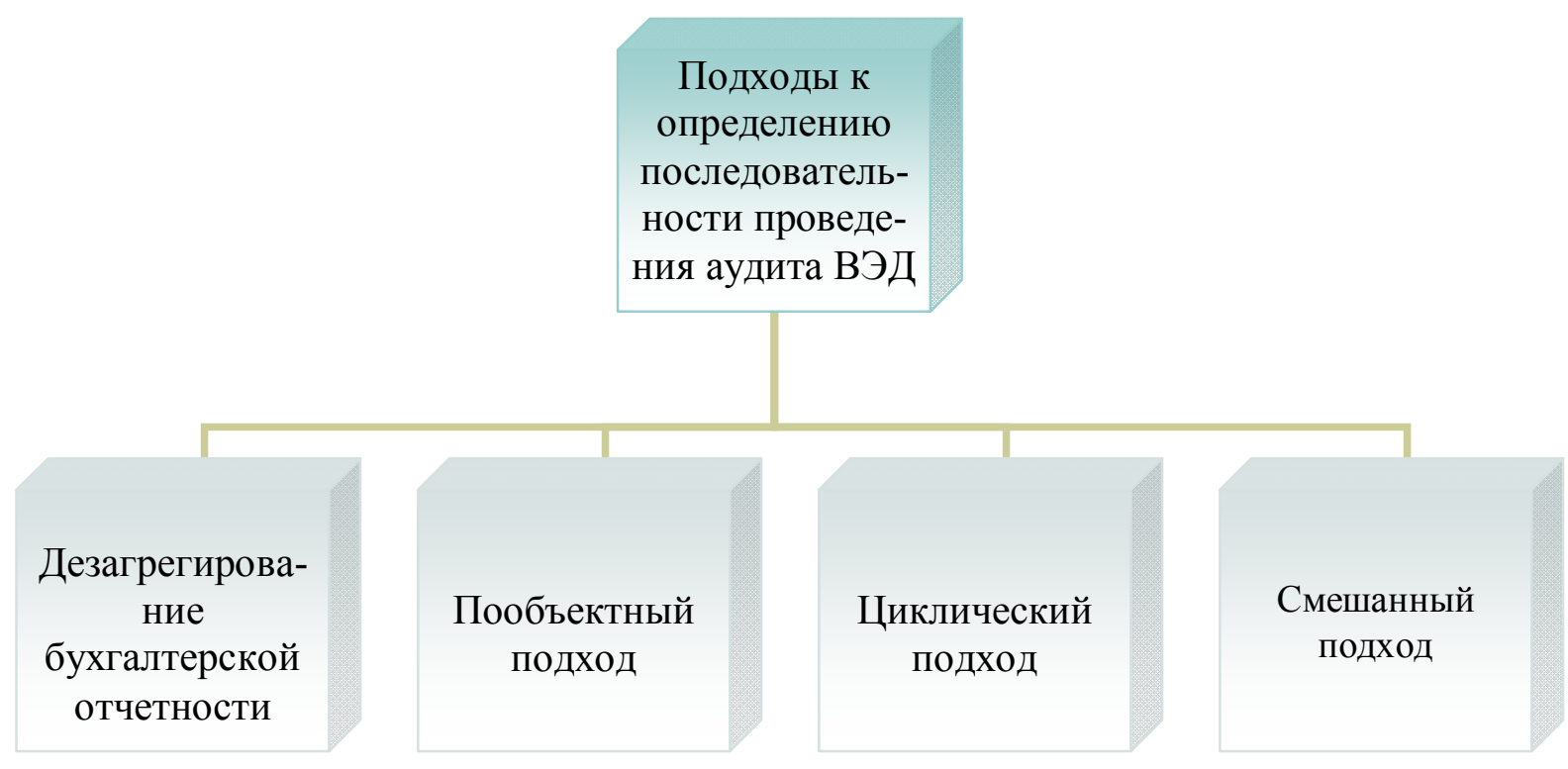

Рис. 5. Подходы к определению последовательности проведения аудита внешнеэкономической деятельности 4

Исходя из вышесказанного, основная цель аудита экспортно-импортных операций - это установление соответствия этих операций нормам действующего законодательства, целесообразности их совершения, а также полноты и достоверности отражения данных операций в учете организации.

\section{2. Источники информации аудита внешнеэкономической деятельности}

Для достижения основной цели аудита ВЭД аудитору необходимо обеспечить достаточное количество аудиторских документов, в процессе сбора которых аудитор должен решить, на каком уровне сбора и обработки учетной информации возможно получение требуемых фактов.

Особенностью внешнеэкономических сделок является то, что они

\footnotetext{
${ }^{4}$ Составлена авторами
} 
выходят за рамки одного государства, а значит информационная база значительно шире, чем при оценке других видов операций предприятия.

При классификации информации для аудита целесообразно разделение всех источников на внутренние и внешние.

В качестве источника внешней информации при проведении проверки организаций, осуществляющих внешнеэкономическую деятельность, прежде всего, необходимо выделить информационные ресурсы банков, таможенных органов, осуществляющих контроль за внешнеэкономической деятельностью организаций. К таким источникам информации относятся, например, грузовая таможенная декларация / транзитная декларация (ГТД), паспорт экспортной сделки (ПС), платежные документы уполномоченных банков.

Получение информации из указанных источников является эффективным способом сбора и обобщения аудиторских доказательств.

Помимо приведенных выше внешних источников информации внешнеэкономических операций, к ним также относятся:

- Информация о политической и экономической ситуации в отношении стран, субъектами которых являются контрагенты по сделке.

- Информация о денежно - кредитной и бюджетной политике государства.

- Отраслевая информация.

- Х Характеристика контрагентов.

- Законодательная и справочно-информационная базы.

- Заключения официальных государственных органов, внешних аудиторов и иных организаций, уполномоченных проводить проверки.

- Информация СМИ, сети Интернет.

К внутренним источникам информации относятся сведения, создаваемые самим предприятием:

- Правовые документы предприятия.

К ним относятся учредительные документы, которые являются обоснованием для аудитора при определении возможности осуществления 
данного рода деятельности. Кроме того, правильность их составления, своевременность оформления и регистрации изменений позволяет сделать вывод о законности существования предприятия в целом. С правовой точки зрения аудитор также должен оценить банковские и таможенные документы.

- Учетная и налоговая политики.

- Внешнеторговые контракты.

- Договоры с транспортными, посредническими, экспедиторскими и другими организациями.

- $\quad$ Первичные документы.

К ним относятся товарные накладные, инвойсы, акты, счетафактуры, книги покупок и книги продаж, ведомости учета готовой продукции, ведомости учета отгруженной экспортной продукции и т.д.

- База данных бухгалтерского учета.

- Данные бухгалтерской отчетности.

- Внеучетные источники информации такие, как, например, внутренние приказы организации, осуществляющих внешнеэкономическую деятельность.

Документы, служащие источниками информации для проведения аудита ВЭД, можно представить с помощью таблицы 5.

Таблица 5

Источниками информации для проведения аудита ВЭД 5

\begin{tabular}{|c|l|c|c|}
\hline $\begin{array}{c}\text { № } \\
\text { п/п }\end{array}$ & \multicolumn{1}{|c|}{ Вид документа } & \multicolumn{1}{|c|}{$\begin{array}{c}\text { Наличие в } \\
\text { банке }\end{array}$} & $\begin{array}{c}\text { Наличие в } \\
\text { организации }\end{array}$ \\
\hline 1 & \multicolumn{1}{|c|}{$\mathbf{2}$} & $\mathbf{3}$ & \\
\hline 1. & $\begin{array}{l}\text { Документы на открытие валютного счета (карточка } \\
\text { образцов подписей, учредительные документы, заявление } \\
\text { на открытие счета, документы о постановке на учет в } \\
\text { налоговых органах и внебюджетных фондах, органах } \\
\text { статистики, договор на расчетно-кассовое обслуживание, } \\
\text { документ обоплатеза открытие счета и др.) }\end{array}$ & + \\
\hline 2. & $\begin{array}{l}\text { Документы, подтверждающие полномочия лиц, } \\
\text { подписывающих внешнеторговые документы и } \\
\text { распоряжающихся валютными счетами }\end{array}$ & + \\
\hline
\end{tabular}

\footnotetext{
${ }^{5}$ Доработана авторами
} 


\begin{tabular}{|c|c|c|c|}
\hline 1 & 2 & 3 & 4 \\
\hline 3. & Выписки из лицевых счетов & + & + \\
\hline 4. & Платежные документы & + & + \\
\hline 5. & $\begin{array}{lccc}\text { Внешнеторговые } & \text { контракты } \quad \text { (договоры) } & \text { и } & \text { все } \\
\text { необходимые дополнения и изменения к ним } & & \end{array}$ & + & + \\
\hline 6. & Паспорта сделок & + & + \\
\hline 7. & $\begin{array}{l}\text { Грузовые таможенные декларации / Транзитные } \\
\text { декларации (копии) }\end{array}$ & + & + \\
\hline 8. & Учетные карточки таможни (подлинники, копии) & + & + \\
\hline 9. & $\begin{array}{l}\text { Товаро-сопроводительные документы, на основании } \\
\text { которых проводится оплата по аккредитивной форме } \\
\text { (инкассо) }\end{array}$ & + & + \\
\hline 10. & $\begin{array}{l}\text { Товаро - сопроводительные документы при } \\
\text { использовании банковского перевода }\end{array}$ & - & + \\
\hline 11. & Досье клиентов банка по открытым паспортам сделок & + & - \\
\hline 12. & $\begin{array}{l}\text { Регистры аналитического учета паспортов сделок, } \\
\text { позволяющие } \\
\text { поступления } \\
\begin{array}{l}\text { регсполировной } \\
\text { регистрации) }\end{array}\end{array}$ & + & + \\
\hline 13. & $\begin{array}{l}\text { Документы, которыми оформляются результаты } \\
\text { внутреннего контроля и аудита исследуемого раздела } \\
\text { учета }\end{array}$ & + & + \\
\hline 14. & $\begin{array}{l}\text { Заявления на проведение экспертиз обоснованности } \\
\text { недополучения или задержки получения экспортной } \\
\text { валютной выручки. Выписки из протоколов } \\
\text { заседаний экспертной группы МВЭС России о } \\
\text { результатах экспертизы }\end{array}$ & + & + \\
\hline 15. & Отчеты банка, представляемые в Банк России & + & - \\
\hline 16. & Отчеты банка, представляемые в таможенные органы & + & - \\
\hline
\end{tabular}

Основные контролируемые элементы первичной учетной документации в организации и в уполномоченном банке совпадают, несмотря на то, что они поразному отражают информацию в своем аналитическом и синтетическом учете, формируют регистры и сводные отчетные формы.

Содержащаяся в перечисленных документах информация необходима аудитору для сбора аудиторских доказательств. Поскольку объективность доказательств зависит от их источника по отношению к организации, 
информация, полученная из банка, будет являться внешней и ее вес в совокупности всех других доказательств, собранных в процессе аудита, будет более значимым.

Такие доказательства согласно Федерального правила (стандарта) № 5 "Аудиторские доказательства" могут быть получены по запросу аудиторской организации. По отношению же к банку внешней будет информация, полученная по запросу, направленному организации - клиенту банка, хотя точно такая же информация, полученная по документам самого банка, внутренняя и, следовательно, менее объективная (доказательная).

Однако, стоит отметить, что для получения внешних доказательств существуют определенные препятствия. Так, законодательно не закреплена обязанность экономического субъекта отвечать на запросы аудитора. Организация и банк сами принимают решение, отвечать им на запрос аудитора или нет. Если даже аудитор в своем запросе будет делать ссылку на положения аудиторских стандартов, это не обязывает экономический субъект отвечать на запрос аудитора.

Еще одним препятствием для получения внешних доказательств являются традиции ведения бухгалтерского учета. Каждый экономический субъект имеет свои традиции, свою культуру учета, поэтому возможности ответить на получаемые запросы у различных организаций разные. В настоящее время ответственность предусмотрена только за непредставление ответа на официальный запрос налогового органа (гл.15 - 16 Налогового кодекса Российской Федерации).

Таким образом, можно отметить, что вероятность получения ответа на запрос аудитора достаточно мала.

При формировании мнения о достоверности отчетности аудиторская организация может использовать информацию, которой располагает сама, т.е. сведения, которые получены в ходе аудиторской деятельности этой организации. Это могут быть, например, данные о результатах аудита банка и аудита ВЭД организаций, которые обслуживаются в данном банке. Таким 
образом, реализуется интеграционный подход к аудиту ВЭД. Особенно актуален этот подход для отдельных регионов, в которых действует небольшое число самостоятельных банков, обслуживаемых одной и той же аудиторской организацией.

Интеграционный подход, применяемый в рамках одной аудиторской организации, позволяет повысить объективность аудиторских доказательств, что в свою очередь снижает аудиторский риск, следовательно, может быть уменьшен объем аудиторских выборок и снижены трудозатраты аудиторской организации в целом. Комплексное изучение характера ошибок, допускаемых экономическими субъектами - участниками ВЭД, позволит аудиторской организации установить причины их возникновения и подготовить для своих клиентов рекомендации по устранению этих ошибок.

Аудиторская организация может проводить тематические совместные семинары для организаций и банков, которые обслуживают эти организации, в результате чего, несомненно, повысится качество ведения бухгалтерского учета, имидж самой аудиторской организации, ее клиенты получат уверенность в том, что учет у них ведется без ошибок, следовательно, значительно снизится риск возникновения ответственности. В работе таких семинаров желательно участие контролирующих органов, в частности, таможенных органов, представителей отделений национальных банков и органов валютного контроля. Следует отметить, что на уровне регионов это сделать гораздо проще, чем на уровне Российской Федерации.

Реализация интеграционного подхода возможна на основе единых форм рабочей документации, используемой аудиторской организацией при проведении аудита ВЭД как в банках, так и в организациях.

Существуют общие контрольные точки при проверке любой организации.

1. Законность совершения операций по валютному счету (полномочия лиц на открытие валютного счета (текущего и транзитного), наличие соответствующих лицензий на ВЭД, учредительные документы).

2. Полнота представленных документов - непрерывность ведения учета 
по валютным счетам (сличаются и прослеживаются первичные банковские документы по счету). Наличие всех отчетов, предусмотренных условиями расчетно-кассового обслуживания и нормами законодательства, а также контрактов, оформленных в соответствии с международными правилами. Соответствие условий контрактов, заключенных организацией, данным паспортов сделок.

3. Своевременность отражения на счетах бухгалтерского учета операций по зачислению экспортной валютной выручки.

4. Своевременность предоставления в банк отчетов об использовании иностранной валюты, снятой с текущего валютного счета, на командировочные расходы. Обоснованность расходования этой валюты.

5. Доказательства объективности непоступления экспортной валютной выручки (переписка клиента, заключения Минпромторга России и Торгово-промышленной палаты).

6. Наличие соответствующих лицензий и квот на осуществление экспортной сделки в случаях, предусмотренных законодательством.

7. Своевременность и правильность переоценки имущества и обязательств, стоимость которых выражена в иностранной валюте; полнота ее отражения в аналитическом учете.

8. Эффективность системы внутреннего контроля движения экспортных товаров в организации и поступления валютной выручки в банк.

9. Обоснованность платежей в иностранной валюте, предусмотренных контрактом.

10. Обеспечение контроля за возмещением валютных платежей организации, выполненных по просьбе контрагента и не входящих по условиям поставки в обязанности экспортера.

Такая методика, на взгляд авторов, едина для разработки общего плана аудита и детализированной программы аудита по каждому клиенту. Она позволяет выявить ошибки, которые возникают при отражении операций по 
счетам и связаны, как правило, с нарушением сроков проведения операций, а также внесением изменений и дополнений в контракт после отгрузки товара.

Важное значение имеет планирование первичного документооборота до начала выполнения заключенных контрактов. Должны быть составлены систематизированные перечни первичных документов, подлежащих обязательному оформлению на соответствующих стадиях товародвижения и расчетов. Следует указывать ответственных за оформление и своевременную сдачу в бухгалтерию должностными лицами соответствующих документов.

Документооборот как необходимый элемент учета организации и банки должны отражать в учетной политике. Документооборот также подлежит контролю с точки зрения аудита.

\section{3. Особенности и отличие аудита внешнеэкономической деятельности от других форм экономического контроля внешнеэкономической деятельности}

Внешнеэкономическая деятельность (ВЭД) организации, как уже отмечалось ранее, подлежит контролю со стороны различных контролирующих органов и организаций. Целью такого контроля в основном является проверка правильности ведения валютных операций, предотвращение утечки капитала за границу, проверка законности проведения внешнеэкономических сделок.

К проблеме валютного контроля обращаются многие специалисты. Одни рассматривают проблемы утечки капитала за границу, другие - проблемы контроля товарных операций, совершаемых в валюте.

При этом стоит заметить, что валютный контроль является предметом исследования и при оценке соблюдения таможенного законодательства.

Для реализации государством комплекса административных мер, обеспечивающих максимально полный возврат валютной выручки от экспортных поставок, принимаются различные формы отчетности по валютному контролю.

Аудиторские организации при разработке внутренних стандартов могут 
использовать единые подходы к аудиту ВЭД в рамках банковского и общего аудита. Это возможно в случае использования механизма валютного контроля, действие которого основано на сопоставлении передаваемой таможенными органами информации о стоимости экспортируемого товара и дате его перемещения через российскую таможенную границу и информации уполномоченных банков о размере валютных средств, уплаченных за данный товар, и дате поступления экспортной выручки. При этом экспортер обязан обеспечить зачисление валютной выручки от экспорта на свои валютные счета в уполномоченных банках Российской Федерации. Результаты сопоставления отражаются в паспорте экспортной сделки.

Кроме того, контролируется расходование валютных средств организации, снимаемых с валютных счетов на командировочные расходы. Основные элементы методики аудита и учета операций по расчетам с подотчетными лицами, в том числе в иностранной валюте, также рассматриваются в ходе аудита внешнеэкономической деятельности.

При осуществлении таможенного и валютного контроля и таможенного оформления товаров, вывозимых с таможенной территории Российской Федерации в соответствии с режимом экспорта, по внешнеторговым сделкам (включая бартерные сделки), предусматривающим расчеты в иностранной валюте, учитывается, что требование обязательного зачисления на счета в уполномоченных банках всей валютной выручки от экспорта в сроки, определенные законодательством для исполнения текущих валютных операций или Банком России для валютных операций, связанных с движением капитала, установлено ст.98 Таможенного кодекса Российской Федерации.

Таможенный орган, принимая груз к оформлению, требует сообщать реквизиты валютного счета, на который будет переведена экспортная выручка (эта информация содержится в паспорте сделки). По окончании таможенного оформления груза в уполномоченный банк направляется извещение о совершении экспортной поставки. Завершается контрольная процедура уведомлением о зачислении уполномоченным банком валютной выручки от 
экспорта.

При проведении аудита внешнеэкономической деятельности предприятия аудитор сталкивается с необходимостью применения значительного числа нормативных актов в области валютного и таможенного регулирования.

Аудитор должен глубоко изучить особенности, задачи и нормативную базу бухгалтерского учета внешнеэкономической деятельности, при этом должны учитываться отличия внешнеэкономических операций от аналогичных коммерческих операций, совершаемых внутри страны.

Эти отличия заключаются в следующем.

Во-первых, они связаны с выдачей и получением платежных документов в иностранной валюте, с покупкой и продажей валюты, с движением других валютных ценностей, а также с перемещением ТМЦ через границу России и получением и оказанием услуг за рубежом.

Во-вторых, при выходе на внешний рынок российские участники внешнеэкономической деятельности вступают во взаимодействие не только с российскими коммерческими предприятиями, кредитными организациями, государственными контролирующими органами, но и с иностранными организациями.

Во внешнеторговых контрактах должны быть учтены нормы не только российского законодательства, но и международного права, особенности торговли на отдельных товарных рынках и биржах, региональные обычаи. В зависимости от условий поставки и расчетов, которые могут значительно отличаться от условий купли-продажи на внутреннем рынке, может возникнуть необходимость отражения в бухгалтерском учете и на балансе организации ТМЦ, находящихся за пределами России, а также нести дополнительные расходы, часть из которых оплачивается в иностранной валюте.

В-третьих, особенностью внешнеэкономических операций является необходимость пересчета иностранной валюты в рубли в момент совершения операций, а также при переоценке валютных статей баланса на отчетную дату, что требует отражения в бухгалтерском учете курсовых разниц. 
B-четвертых, аудитор должен учитывать особенности налогообложения внешнеэкономических операций.

В ходе проведения аудита внешнеэкономической деятельности аудитору необходимо проверить правильность оформления следующих операций:

* По экспорту товаров в счет государственного кредита.

* По экспорту товара с предоставлением коммерческого кредита.

* По экспорту товаров с консигнацией складов за границей.

* По переработке экспортных товаров за границей.

* По экспорту товаров через посредника.

* По импорту товаров через посредника.

* По реализации импортных товаров с консигнационных складов в России.

* По импорту за счет централизованных валютных и кредитных ресурсов.

* По экспорту товаров, по реимпорту товаров, бартерных операций.

* Связанных с арендой (лизингом) импортного оборудования.

* По оказанию и выполнению внешнеэкономических работ и услуг.

* По покупке и продаже иностранной валюты.

* По учету денежных средств на валютных счетах предприятия.

* По учету расчетных операций в иностранной валюте.

* По расчетам с подотчетными лицами в иностранной валюте.

* По кредитам и займам в иностранной валюте.

Осуществляя аудит внешнеэкономической деятельности, аудитор должен подтвердить правильность определения:

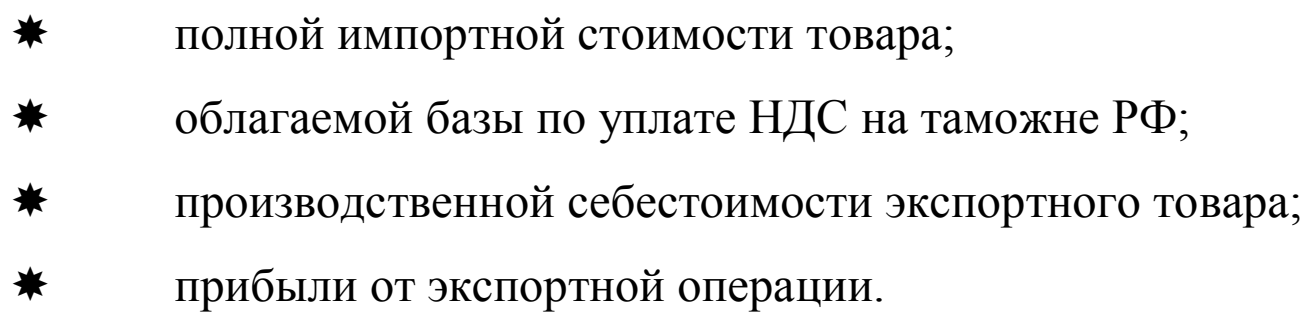

Кроме того, аудитору необходимо выяснить:

* Имеет ли право организация на осуществление внешнеэкономической 
деятельности, а также лицензию и квоту на экспорт товаров и услуг.

* Соответствие сведений, указанных в паспорте сделки, условиям контракта.

* Правильность данных, указанных в грузовой таможенной декларации/ транзитной декларации.

* Полноту зачислений валютной выручки на транзитный валютный счет экспортера.

* Правильность оформления документов при проведении экспортных операций.

Кроме того, аудитор может также принять решение о включении в программу проверки участников внешнеэкономической деятельности и других направлений, исходя из своего профессионального суждения и знания бизнеса проверяемого экономического субъекта.

\section{Контрольные вопросы}

1. В чем состоят сущность и цели аудита внешнеэкономической деятельности?

2. Охарактеризуйте виды аудита внешнеэкономической деятельности.

3. Каковы критерии деятельности экономических субъектов, по которым их отчетность подлежит обязательной проверке.

4. Дайте определение понятия и задач аудита внешнеэкономической деятельности.

5. Охарактеризуйте систему финансового контроля и аудита в России при осуществлении аудита внешнеэкономической деятельности.

6. Дайте характеристику видов и методов контроля.

7. Охарактеризуйте организационные основы аудита ВЭД.

8. В чем состоит информационная база аудита внешнеэкономической деятельности. 


\section{Примеры решения задач}

1. Аудиторская организация, проводящая обязательный ежегодный аудит организации, осуществляющей ВЭД, получила от нее же предложение заключить договоры на оказание двух видов услуг: на обучение бухгалтерского персонала и на составление бухгалтерской отчетности. Единственный специалист аудиторской организации по организациям данного профиля является сыном заместителя главного бухгалтера коммерческого банка. Примет ли аудиторская организация оба эти предложения. А если одно, то какое ?

Решение: Требование независимости специалиста аудиторской организации от экономического субъекта обязательно при оказании сопутствующих аудиту услуг, не совместимых с проведением обязательной аудиторской проверки. Так как в рассматриваемой ситуации проведение аудита не совместимо с составлением бухгалтерской отчетности, то аудиторская организация может принять только предложение о заключении договора на обучение бухгалтерского персонала.

2. Индивидуальный аудитор, являющийся специалистом по внешнеэкономической деятельности, получил предложение от организации провести обязательную аудиторскую проверку ее бухгалтерской финансовой отчетности. Примет ли индивидуальный аудитор это предложение?

Решение: Согласно Ф3 «Об аудиторской деятельности» обязательный аудит проводится аудиторскими организациями, следовательно, индивидуальный аудитор должен отказаться от предложения организации.

\section{Задачи для самостоятельного решения}

Задача 1. Организация, размер уставного капитала которой составляет 1 млн. рублей, имеет годовой объем доходов 45 млн. рублей и сумму активов баланса на конец отчетного года 15 млн. рублей. Полежит ли обязательному аудиту ее бухгалтерская финансовая отчетность? 
Задача 2. Преподаватель по бухгалтерскому учету одного из колледжей, пройдя аттестацию на право осуществления аудиторской деятельности, получил квалификационный аттестат аудитора. Затем, оставаясь преподавателем колледжа он устроился по совместительству аудитором в аудиторскую фирму. Имеются ли в его действиях противоречия с законодательством?

Задача 3. В связи с предстоящей в ближайшее время налоговой проверкой организация, осуществляющая ВЭД, обратилась к аудиторской организации с предложением провести аудит расчетов с бюджетом по уплате налогов. Одним из условий заключения договора на проведение аудита стало осуществление аудитором проверки по программе, утвержденной руководством организации. Имеет ли место конфликт интересов? Если да, то, как его преодолеть ?

\section{Контрольные тесты}

1. Совет по аудиторской деятельности при уполномоченном федеральном органе создается в целях:

а) контроля за деятельностью аудиторских организаций и индивидуальных аудиторов;

б) рассмотрения аудиторских заключений по результатам проверок;

в) учета мнения профессиональных участников рынка аудиторской деятельности;

г) аттестации аудиторов.

2. Имеет ли право назначать проверку качества аудиторского заключения:

а) аккредитованное профессиональное аудиторское объединение;

б) орган, выдавший лицензию на осуществление аудиторской деятельности и (или) аккредитованное профессиональное аудиторское объединение;

в) орган государственного налогового контроля по месту регистрации;

г) Министерство финансов РФ. 


\section{Глава 4. Нормативно-правовое регулирование и организация аудита внешнеэкономической деятельности}

\section{1. Нормативно-правовое регулирование и организация аудита внешнеэкономической деятельности}

В России система нормативного регулирования аудиторской деятельности находится в стадии становления. Происходит процесс пересмотра прав и обязанностей органов, регулирующих аудиторскую деятельность, определение роли и функций государственных и общественных аудиторских организаций. Следует отметить, что в России регулирование аудиторской деятельности проводится как органами государственного регулирования, к которым относятся Министерство финансов РФ, Банк России, так и общественными саморегулируемыми организациям аудиторов [31].

Сегодня в России используется четырехуровневая система нормативного реулирования аудиторской деятельности.

Эта система включает 4 основных уровня, расположенных сверху вниз.

Каждый уровень обладает определенными видами нормативных документов, регулирующих аудиторскую деятельность в России, областью регулирования и степенью их разработанности [31].

Систему нормативного регулирования аудиторской деятельности в России можно представить с помощью таблицы 6.

Как показывает таблица 6, первый (верхний) уровень включает Федеральный закон «Об аудиторской деятельности» № 307 - Ф3, который принят 30 декабря 2008 года. Федеральный закон «Об аудиторской деятельности» в России относится к основным законодательным актам, который определяет место аудита в финансово-хозяйственной деятельности в качестве ее необходимого равноправного элемента.

К документам второго уровня, регулирующим аудиторскую деятельность в РФ, относятся федеральные правила (стандарты). Они определяют общие вопросы регулирования аудиторской деятельности, 
Таблица 6

Система нормативного регулирования аудиторской деятельности в РФ

\begin{tabular}{|c|c|c|c|}
\hline $\begin{array}{l}\text { Уровни } \\
\text { регули- } \\
\text { рования }\end{array}$ & $\begin{array}{c}\text { Виды и } \\
\text { наименования } \\
\text { нормативных } \\
\text { документов } \\
\end{array}$ & $\begin{array}{c}\text { Область регулирования } \\
\text { и использования }\end{array}$ & $\begin{array}{c}\text { Степень } \\
\text { разработанности }\end{array}$ \\
\hline I & $\begin{array}{c}\text { Федеральный закон «Об } \\
\text { аудиторской } \\
\text { деятельности» № 307-Ф3 }\end{array}$ & $\begin{array}{c}\text { Определяет место, цель и } \\
\text { задачи аудита в } \\
\text { финансово-экономической } \\
\text { системе, порядок осуществления и } \\
\text { оформления результатов аудита }\end{array}$ & $\begin{array}{c}\text { Закон принят } 30 \text { декабря } \\
2008 \text { года }\end{array}$ \\
\hline \multirow[b]{2}{*}{ II } & $\begin{array}{c}\text { Федеральные Правила } \\
\text { (стандарты) аудиторской } \\
\text { деятельности }\end{array}$ & $\begin{array}{c}\text { Определяют общие вопросы } \\
\text { регулирования аудиторской } \\
\text { деятельности, обязательные } \\
\text { для всех объектов, } \\
\text { устанавливают нормы аудита, } \\
\text { обязательные для всех субъек- } \\
\text { тов рынка аудиторских услуг }\end{array}$ & $\begin{array}{c}\text { Федеральные стандарты } \\
\text { (разработано и утверждено } \\
34 \text { стандарта). }\end{array}$ \\
\hline & $\begin{array}{c}\text { Законодательные и } \\
\text { подзаконные } \\
\text { нормативные акты в } \\
\text { области регулирования } \\
\text { аудиторской деятельности }\end{array}$ & $\begin{array}{c}\text { Устанавливают общие } \\
\text { положения по регулированию } \\
\text { аудиторской деятельности для } \\
\text { аудиторских организаций и } \\
\text { индивидуальных аудиторов }\end{array}$ & $\mid \begin{array}{c}\text { Разработаны в соответствии с } \\
\text { ФЗ «Обаудиторской деятельности» } \\
\text { нормативные документы в } \\
\text { области аттестации } \\
\text { аудиторской деятельности и др. } \\
\text { Пересматриваются и } \\
\text { дополняются по мере } \\
\text { необходимости в соответствии с } \\
\text { Ф3 «Об аудиторской } \\
\text { деятельности» № } 307 \text { - Ф3 }\end{array}$ \\
\hline \multirow{2}{*}{ III } & $\begin{array}{c}\text { Внутренние правила } \\
\text { (стандарты) } \\
\text { аккредитованных } \\
\text { профессиональных } \\
\text { объединений }\end{array}$ & $\begin{array}{c}\text { Регулирование } \\
\text { специфических вопросов } \\
\text { аудиторской деятельности на } \\
\text { уровне профессиональных } \\
\text { объединений }\end{array}$ & $\begin{array}{c}\text { Разрабатываются } \\
\text { аккредитованными } \\
\text { профессиональными } \\
\text { аудиторскими } \\
\text { объединениями }\end{array}$ \\
\hline & $\begin{array}{l}\text { Нормативные документы } \\
\text { министерств и ведомств }\end{array}$ & $\begin{array}{c}\text { Регулирование специфических } \\
\text { особенностей аудита по видам: } \\
\text { рбщий, страховой, инвестиционных } \\
\text { институтов, банковский }\end{array}$ & $\begin{array}{c}\text { Министерствами и } \\
\text { ведомствами принят и } \\
\text { разрабатывается ряд } \\
\text { документов по видам аудита }\end{array}$ \\
\hline IV & $\begin{array}{c}\text { Внутренние } \\
\text { аудиторские стандарты }\end{array}$ & $\begin{array}{c}\text { При проведении аудита и } \\
\text { сопутствующих аудиту услуг }\end{array}$ & $\begin{array}{c}\text { Разрабатываются аудиторскими } \\
\text { организациями и } \\
\text { индивидуальными аудиторами }\end{array}$ \\
\hline
\end{tabular}

В настоящее время разработано и принято Правительством РФ 34 федеральных стандарта.

\footnotetext{
${ }^{6}$ Доработана авторами
} 
Документы второго уровня также включают законодательные и подзаконные нормативные акты в области регулирования аудиторской деятельности, устанавливающие общие положения по регулированию аудиторской деятельности для аудиторских организаций и индивидуальных аудиторов.

Tретий уровень охватывает внутренние стандарты профессиональных аудиторских объединений, а также нормативные акты министерств и ведомств, устанавливающие правила организации аудиторской деятельности и проведения аудита применительно к конкретным отраслям, организациям и по отдельным вопросам налогообложения, финансов, бухгалтерского учета, хозяйственного права [31].

Четвертый уровень включает внутренние стандарты аудиторской деятельности, которые разрабатывают аудиторские организации и индивидуальные аудиторы на базе федеральных правил (стандартов) и практики аудита. Содержание и форма таких документов - прерогатива аудиторских фирм, их ноу-хау. Такие стандарты определяют качество работы и престиж аудиторских фирм [31]. На основе внутренних стандартов аудиторской деятельности организуется деятельность аудиторских организаций и индивидуальных аудиторов.

Формирование аудитором мнения о достоверности экспортных и импортных операций и их законности должно основываться на сравнении фактического состояния учета и отчетности с нормами действующего законодательства и принципами бухгалтерского учета при отражении операций по экспорту и импорту материальных ценностей.

Основные нормативные акты, регламентирующие порядок бухгалтерского учета по внешнеэкономическим операциям:

1. Гражданский кодекс Российской Федерации (часть вторая) от 26 января 1996 г. № 14-Ф3.

2. Налоговый кодекс РФ, часть первая и вторая.

3. Таможенный кодекс РФ. 
4. Положение по ведению бухгалтерского учета и бухгалтерской отчетности в РФ, утвержденной Приказом Минфина России от 29.07.1998 № 34н.

5. Федеральный закон «О бухгалтерском учете» от 21.11.1996 № 129 - Ф3

6. Федеральные законы: «О валютном регулировании и валютном контроле» (Закон РФ от 9.10.1992г. № 3615, ред. от 10.12.2003 № 173 Ф3), «О таможенном тарифе» (Закон РФ от 21.05.1993 № 5003-1, ред. от 08.12.2003 с изм. от 29.12.2003), «Об основах государственного регулирования внешнеторговой деятельности» от 08.12.2003г. № 164-Ф3).

7. План счетов бухгалтерского учета и Инструкция по применению Плана счетов бухгалтерского учета финансово-хозяйственной деятельности организаций (Приказ Минфина России от 31.10.200 № 94н).

8. Положение по бухгалтерскому учету «Учет активов и обязательств, стоимость которых выражена в иностранной валюте», ПБУ 3/2000 (Приказ Минфина РФ от 10.01.2000 № 2н).

9. Положение по бухгалтерскому учету «Учетная политика организации», ПБУ 1/98 (Приказ Минфина РФ от 09.12.98 № 60н).

10. Положение по бухгалтерскому учету «Бухгалтерская отчетность организации», ПБУ 4/99 (Приказ Минфина РФ от 06.07.99 № 43н).

11. Положение по бухгалтерскому учету «Учет материальнопроизводственных запасов»,ПБУ 5/01 (Приказ Минфина РФ от 09.06.01 № 44н).

12. Положение по бухгалтерскому учету «Доходы организации» ПБУ 9/99, (Приказ Минфина РФ от 06.05.99 № 32н).

13. Положение по бухгалтерскому учету «Расходы организации» ПБУ 10/99, (Приказ Минфина РФ от 06.05.99 № 33н) устанавливает правила формирования в бухгалтерском учете информации о расходах коммерческих организаций.

14. Межправительственные конвенции и соглашения об избежании двойного налогообложения (Конвенция $\mathrm{OOH}$ о договорах международной купли - продажи товаров).

15. Внутриведомственные нормативные акты Банка России, Министерства 
Финансов РФ, Федеральной таможенной службы РФ (инструкции, положения, приказы, указания, методические рекомендации, разъяснения).

16. Международные правила поставок товаров (ИНКОТЕРМС) и правила оформления и доставки грузов и т.д.

В России для регулирования аудиторской деятельности в соответствии с Ф3 «Об аудиторской деятельности» создается уполномоченный федеральный орган государственного регулирования аудиторской деятельности, функции которого осуществляет уполномоченный федеральный орган исполнительной власти.

В соответствии с Постановлением Правительства РФ № 80 «О вопросах государственного регулирования аудиторской деятельности в РФ» от 06.02.02 года таким органом является Министерство финансов РФ.

К основным функциям уполномоченного федерального органа относятся [31]:

1. Издание в пределах своей компетенции нормативных правовых актов, регулирующих аудиторскую деятельность.

2. Организация разработки и представление на угверждение Правительству РФ федеральных правил (стандартов) аудиторской деятельности.

3. Организация в установленном законодательством РФ порядке системы аттестации, обучения и повышения квалификации аудиторов в РФ, лицензирование аудиторской деятельности.

4. Организация системы надзора за соблюдением аудиторскими организациями и индивидуальными аудиторами лицензионных требований и условий.

5. Контроль за соблюдением аудиторскими организациями и индивидуальными аудиторами федеральных правил (стандартов) аудиторской деятельности.

6. Определение объема и разработка порядка представления аудиторскими организациями и индивидуальными аудиторами отчетности аудиторских организаций и индивидуальных аудиторов 
и финансовой отчетности.

7. Ведение государственных реестров аттестованных аудиторов аудиторских организаций, индивидуальных аудиторов, профессиональных аудиторских объединений и учебно-методических центров в соответствии с Положением о ведении реестров, утвержденным уполномоченным федеральным органом, а также предоставление информации, содержащейся в реестрах, всем заинтересованным лицам.

8. Аккредитация профессиональных аудиторских объединений.

В связи с принятием Федерального закона от 30.12 .08 г. № 307 - Ф3 "Об аудиторской деятельности", а также во исполнение постановления Правительства Российской Федерации от 06.02.02 г. № 80 "О вопросах государственного регулирования аудиторской деятельности в Российской Федерации" функции федерального органа государственного регулирования аудиторской деятельности в настоящее время осуществляет Минфин России. Таким образом, регулирование аудиторской деятельности по всем направлениям, в том числе и аудит организаций, осуществляющих внешнеэкономическую деятельность, теперь находится в компетенции Минфина России.

\section{2. Направления аудиторских проверок внешнеэкономической деятельности}

Достоверность бухгалтерской (финансовой) отчетности организаций, занимающихся внешнеэкономической деятельностью, представляет собой степень точности данных отчетности, позволяющая ее пользователю делать правильные выводы о результатах хозяйственной деятельности, финансовом и имущественном положении аудируемых лиц и принимать базирующиеся на этих выводах обоснованные решения.

Основываясь на целях и задачах аудита, а также принципе существенности, 
аудитор, принимая решение о проведении аудита внешнеэкономической деятельности, должен определить направления аудиторских проверок внешнеэкономической деятельности, которые включают области повышенного риска искажения данных бухгалтерской (финансовой) отчетности. При этом необходимо учитывать как количественные, так и качественные искажения бухгалтерской (финансовой) отчетности.

К основным направлениям аудита внешнеэкономической деятельности можно отнести:

• законодательно-правовой аспект внешнеэкономической деятельности;

- проверка соблюдения порядка ведения бухгалтерского учета;

- выполнение организацией налоговых обязательств, вытекающих из внешнеторговых контрактов;

- изучение и оценка системы бухгалтерского учета в организации, осуществляющей внешнеэкономическую деятельность;

- исследование постановки аналитического учета внешнеторговых контрактов;

- определение направления и степени влияния внешнеэкономической деятельности на финансовое состояние организации, оценка их экономической целесообразности.

Осуществляя проверку внешнеэкономической деятельности с точки зрения ее соответствия законодательно-правовым актам, аудитор должен выразить независимое мнение о соответствии:

1. формы внешнеторговых контрактов их содержанию;

2. условий внешнеторговых контрактов нормам международного права и гражданского законодательства РФ;

3. операций по исполнению внешнеторговых сделок требованиям валютного и таможенного законодательства РФ.

Проводя проверку внешнеэкономической деятельности с точки зрения соблюдения порядка ведения бухгалтерского учета, аудитор должен сформировать мнение о достоверности отражения в бухгалтерском учете 
внешнеэкономической деятельности, выявив области повышенного риска искажения данных бухгалтерского учета, к которым могут быть отнесены:

1. искажение даты перехода права собственности на товар от продавца к покупателю при экспорте или импорте товаров;

2. своевременность отражения экспортной валютной выручки в бухгалтерском учете;

3. полнота зачисления экспортной валютной выручки на счета в уполномоченных банках РФ;

4. наличие просроченной дебиторской задолженности;

5. обоснованное списание затрат по экспортным операциям;

6. правильность формирования фактической стоимости импортных товаров;

7. своевременность и полнота начисления курсовых разниц;

8. бартерные сделки, реэкспортные, реимпортные и посреднические операции, при отражении которых в бухгалтерском учете чаще всего допускаются ошибки, связанные с недостаточным знанием правовой основы операций.

Следует отметить, что с позиции искажения учетных данных и возникающих налоговых последствий наибольший аудиторский риск связан с использованием участниками внешнеэкономической деятельности нетрадиционных форм заключения внешнеторговых сделок, применяемых в международной практике. Поэтому на такие сделки аудитор должен уделять больше внимания при планировании аудита. Кроме того, такие сделки должны быть выделены в отдельную группу повышенных аудиторских рисков для проведения их комплексного анализа с точки зрения правовых, учетных и налоговых вопросов.

Изучая систему бухгалтерского учета в организации, осуществляющей внешнеэкономическую деятельность, аудитору недостаточно убедиться в ее общей надежности. Поэтому он должен уделить особое внимание при 
планировании аудита внешнеэкономической деятельности анализу разделов внешнеторговых контрактов, имеющих непосредственное отношение к бухгалтерском учету.

Проверяя правильность постановки аналитического учета внешнеэкономической деятельности, аудитор должен включить в план проведения аудита получение аналитических данных с помощью заполнения карточек учета внешнеторговых контрактов на основе самих договоров и первичных документов.

Определение направления и степени влияния внешнеэкономической деятельности на финансовое состояние организации и оценка их экономической целесообразности позволяет аудитору формировать профессиональное суждение о финансовой устойчивости клиента.

Следует отметить, что применение данного направления аудита целесообразно с точки зрения того, что в нашей стране из-за большой протяженности собственной и транзитной территории доля транспортной составляющей в конечной стоимости экспортируемых и импортируемых товаров значительна. Поэтому можно предположить, что по мере неизбежного роста тарифов на перевозки будет снижаться рентабельность внешнеэкономической деятельности, что отрицательно скажется на общем финансовом состоянии организации, осуществляющей внешнеэкономическую деятельность.

\section{3. Пользователи материалов аудиторских заключений при аудите внешнеэкономической деятельности}

Аудиторское заключение является официальным документом, предназначенным для пользователей финансовой (бухгалтерской) отчетности аудируемых лиц, составленным в соответствии с Федеральным правилом (стандартом) аудиторской деятельности № 6 «Аудиторское заключение» и содержащим выраженное в установленной форме мнение аудиторской организации или индивидуального аудитора о достоверности во всех 
существенных отношения финансовой (бухгалтерской) отчетности аудируемого лица и соответствии порядка ведения им бухгалтерского учета законодательству Российской Федерации.

По результатам проведенного аудита внешнеэкономической деятельности пользователям (руководству клиента и его представителям собственника клиента) предоставляется информация, составленная в соответствии с требованиями, предъявляемыми Федеральным правилом (стандартом) аудиторской деятельности № 22 «Сообщение информации, полученной по результатам аудита, руководству аудируемого лица и представителям его собственника».

В результате аудита внешнеэкономической деятельности аудитор должен сообщать информацию руководству и представителям собственника аудируемого лица.

Следует отметить, что руководством аудируемого лица являются лица, отвечающие за повседневное руководство аудируемым лицом, а также осуществление финансово-хозяйственных операций, ведение бухгалтерского учета и подготовку финансовой (бухгалтерской) отчетности (например, генеральный директор, финансовый директор, главный бухгалтер).

Представителями собственника аудируемого лица являются лица или коллегиальные органы, которые осуществляют общий надзор и стратегическое руководство деятельностью аудируемого лица, а также в соответствии с учредительными документами могут контролировать текущую деятельность его руководства, в том числе назначать или освобождать от должности представителей высшего руководства.

Аудитор должен установить надлежащих получателей информации из числа руководства и представителей собственника аудируемого лица, основываясь на собственном профессиональном суждении для определения тех лиц, которым должна сообщаться информация, принимая во внимание управленческую структуру аудируемого лица, обстоятельства аудиторского задания и особенности законодательства Российской Федерации. Аудитору 
следует учитывать права и обязанности соответствующих лиц.

Если управленческая структура аудируемого лица четко не определена или представители собственника не могут быть четко определены в соответствии с условиями задания или согласно законодательству Российской Федерации, то аудитор приходит к соглашению с аудируемым лицом в отношении того, кому должна сообщаться информация.

Во избежание недоразумений в договоре оказания аудиторских услуг (письме о проведении аудита) может быть разъяснено, что аудитор будет сообщать только ту информацию, представляющую интерес для управления, на которую он обратит внимание в результате аудита, и что аудитор не обязан разрабатывать процедуры, специально направленные на поиск информации, имеющей значение для управления аудируемым лицом. В договоре оказания аудиторских услуг (письме о проведении аудита) могут также:

а) указываться форма, в которой будет сообщаться информация;

б) определяться надлежащие получатели информации;

в) определяться конкретные вопросы аудита, представляющие интерес для управления аудируемым лицом, в отношении сообщения информации о которых была достигнута договоренность.

Сообщение информации будет более эффективно при налаживании конструктивных рабочих взаимоотношений между аудитором и руководством или представителями собственника аудируемого лица. Данные взаимоотношения должны развиваться с учетом соблюдения требований профессиональной этики, независимости и объективности.

После проведения аудита внешнеэкономической деятельности аудитор должен рассмотреть информацию и сообщить сведения, представляющие интерес для управления аудируемым лицом, надлежащим получателям такой информации, включающей:

a) общий подход аудитора к проведению аудита и его объему, обеспокоенность аудитора по поводу любых ограничений объема аудита, а также комментарии по поводу уместности любых дополнительных требований 
руководства аудируемого лица;

б) выбор или изменение руководством аудируемого лица принципов и методов учетной политики, которые оказывают или могут оказать существенное влияние на финансовую (бухгалтерскую) отчетность аудируемого лица;

в) возможное влияние на финансовую (бухгалтерскую) отчетность аудируемого лица каких-либо значимых рисков и внешних факторов, которые должны быть раскрыты в финансовой (бухгалтерской) отчетности (например, судебных разбирательств);

г) предлагаемые аудитором существенные корректировки финансовой (бухгалтерской) отчетности как осуществленные, так и не осуществленные аудируемым лицом;

д) существенные неопределенности, касающиеся событий или условий, которые могут в значительной мере поставить под сомнение способность аудируемого лица продолжать непрерывно вести свою деятельность;

е) разногласия аудитора с руководством аудируемого лица по вопросам, которые по отдельности или в совокупности могут являться значимыми для финансовой (бухгалтерской) отчетности аудируемого лица или аудиторского заключения. Сообщаемая в этой связи информация должна включать пояснения важности этого вопроса и сведения о том, был ли данный вопрос разрешен или нет;

ж) предполагаемые модификации аудиторского заключения;

3) другие вопросы, заслуживающие внимания представителей собственника (например, существенные недочеты в области внутреннего контроля, вопросы, касающиеся порядочности руководства аудируемого лица, а также случаи недобросовестных действий руководства);

и) вопросы, освещение которых согласовано аудитором с аудируемым лицом в договоре оказания аудиторских услуг (письме о проведении аудита).

Кроме того, аудитор также должен проинформировать надлежащих получателей информации о том, что: 
а) сведения, сообщаемые аудитором, включают только те вопросы, которые привлекли внимание аудитора в результате аудита;

б) аудит финансовой (бухгалтерской) отчетности не направлен на выявление всех вопросов, которые могут представлять интерес для управления аудируемым лицом.

Аудитор должен своевременно сообщать информацию по результатам аудита внешнеэкономической деятельности, что дает возможность представителям собственника и руководству аудируемого лица оперативно принимать надлежащие меры.

Для своевременного сообщения информации аудитор должен обсудить с представителями собственника и руководства аудируемого лица порядок, принципы и сроки сообщения такой информации. В определенных случаях в связи с необходимостью решения срочного вопроса аудитор может сообщить о нем раныше, чем это было согласовано предварительно.

Аудитор может сообщать надлежащим получателям информацию в устной или письменной форме. На решение аудитора о том, сообщать ли информацию в устной или письменной форме, влияют:

a) размер, структура, организационно-правовая форма и техническое обеспечение аудируемого лица;

б) характер, важность и особенности информации, полученной по результатам аудита, представляющей интерес для управления аудируемым лицом;

в) существующие договоренности между аудитором и аудируемым лицом в отношении регулярных встреч или докладов;

г) принятые аудитором формы взаимодействия с представителями собственника и руководства аудируемого лица.

Если информация, представляющая интерес для управления аудируемым лицом, сообщается в устной форме, аудитору следует документально отразить в рабочих документах эту информацию и реакцию на нее получателей информации. Такие документы могут иметь форму копий протоколов 
обсуждений, проводимых аудитором с представителями собственника и руководства аудируемого лица. В некоторых случаях в зависимости от характера, важности и особенностей информации целесообразно, чтобы аудитор получал от представителей собственника и руководства аудируемого лица письменные подтверждения в отношении любых устных сообщений по вопросам аудита, представляющим интерес для управления аудируемым лицом.

Как правило, аудитор предварительно обсуждает с руководством аудируемого лица вопросы аудита, представляющие интерес для управления аудируемым лицом, за исключением тех вопросов, которые ставят под сомнение компетентность или порядочность самого руководства. Предварительные обсуждения с руководством аудируемого лица имеют важное значение для прояснения фактов и вопросов, а также для того, чтобы дать возможность руководству аудируемого лица предоставить дополнительную информацию. Если руководство аудируемого лица соглашается самостоятельно (без участия аудитора) сообщить информацию, представляющую интерес для управления аудируемым лицом, представителям собственника, то аудитору может не потребоваться повторное сообщение данной информации при условии, что аудитор удовлетворен эффективностью и надлежащим характером сообщения такой информации.

Если аудитор считает, что необходимо модифицировать аудиторское заключение в соответствии с требованиями федерального правила (стандарта) аудиторской деятельности № 6 «Аудиторское заключение», то любая иная письменная информация, направляемая аудитором руководству или представителям собственника аудируемого лица, не может рассматриваться в качестве надлежащей замены модифицированного аудиторского заключения.

Аудитор должен проанализировать, может ли какая-либо информация, полученная по результатам предыдущего аудита, иметь значение для достоверности финансовой (бухгалтерской) отчетности текущего года. Если аудитор приходит к выводу, что такая информация представляет интерес для управления аудируемым лицом, он может принять решение повторно сообщить 
ее представителям собственника аудируемого лица.

При этом стоит отметить, что аудитор обязан выполнять требования законодательства Российской Федерации и Кодекса этики аудиторов России в отношении конфиденциальности информации, полученной по результатам аудита. В некоторых случаях потенциальные конфликты между этическими и правовыми обязательствами аудитора в отношении конфиденциальности и требованиями по предоставлению информации могут носить сложный характер. В данном случае аудитору целесообразно получить юридическую консультацию.

Нормативными правовыми актами Российской Федерации могут устанавливаться обязательства аудитора в отношении сообщения информации, представляющей интерес для управления аудируемым лицом. Эти дополнительные обязательства о сообщении информации могут влиять на содержание, форму и сроки представления аудитором информации надлежащим получателям.

\section{4. Критерии аудита и особенности его информационной базы}

Формирование аудитором мнения о достоверности внешнеэкономической деятельности и ее законности должно основываться на сравнении фактического состояния учета и отчетности с определенными критериями:

1. соблюдение норм действующего законодательства;

2. следование основным принципам бухгалтерского учета при отражении операций по сделкам с материальными и нематериальными ценностями.

Нормы действующего законодательства как критерии аудита внешнеэкономической деятельности можно классифицировать по шести уровням, представленным на рисунке 6.

Оценивая нормативно - правовую базу, регулирующую вопрос законности внешнеэкономической деятельности, аудитор должен удостовериться прежде всего в соблюдении нормативных актов первого уровня, в соответствии с рисунком 6, так как они регулируют основные положения по 


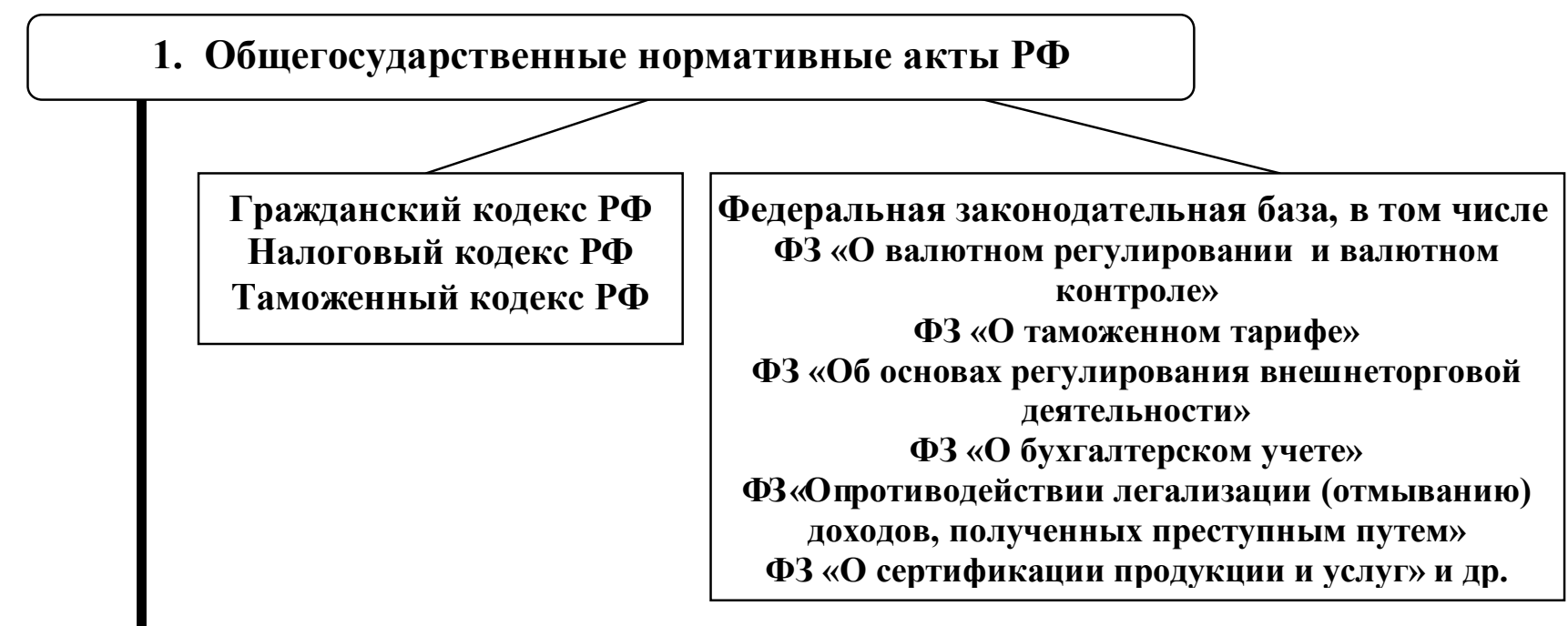

2. Нормативные акты, принимаемые органами РФ общей компетенции (указы и постановления)

\begin{tabular}{|c|c|}
\hline \multicolumn{1}{|c|}{} & \multicolumn{2}{|c|}{ Указ президента РФ «O } \\
первоочередных мерах по & $\begin{array}{c}\text { Постановление правительства РФ «Об } \\
\text { уситвежжении положений о } \\
\text { лицензировании в сфере внешней } \\
\text { контроля в РФ» и др. }\end{array}$ \\
$\begin{array}{c}\text { торговли и о формировании и ведении } \\
\text { федерального банка выданных } \\
\text { лицензий»и др. }\end{array}$ \\
\hline
\end{tabular}

3. Межправительственные конвенции и соглашения об избежании двойного налогообложения

4. Внутриведомственные нормативные акты Банка России, Министерства финансов РФ, Федеральной налоговой службы РФ, Фелеральной таможенной службы РФ

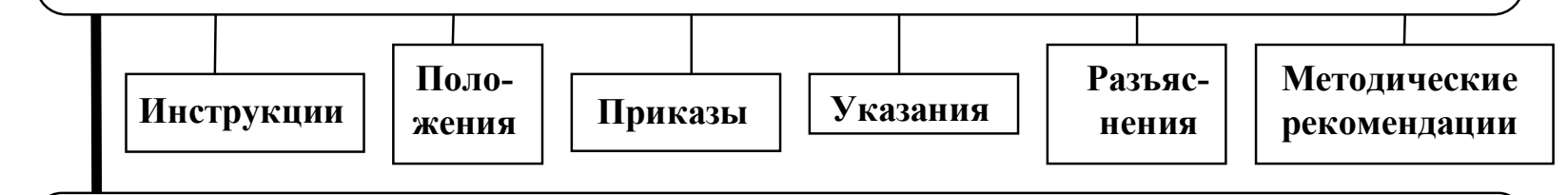

5. Международные правила поставок товаров (ИНКОТЕРМС) и правила оформления и доставки грузов

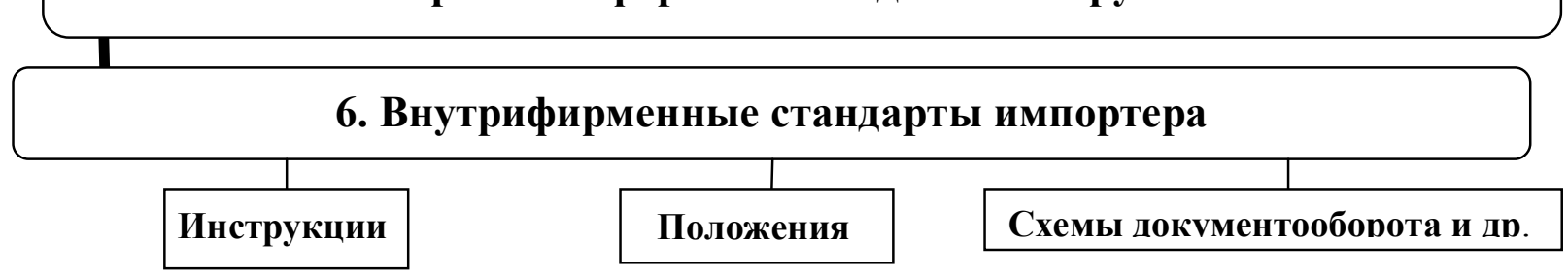

Рис. 6. Критерии аудита внешнеэкономической деятельности ${ }^{7}$

\footnotetext{
${ }^{7}$ Составлена авторами
} 
Так, например, если во внешнеторговом контракте участниками внешнеэкономической сделки не определен момент перехода права собственности, то аудитор должен ориентироваться на нормы Гражданского кодекса РФ, в соответствии с которым предусмотрено как минимум три даты перехода прав собственности, не совпадающие по времени.

В случае аудита импорта услуг аудитор должен в соответствии с Налоговым кодексом РФ определить место реализации услуг для подтверждения законности обложения или освобождения операции от НДС.

При проведении аудита законности определения таможенной стоимости, а также порядка расчета таможенных платежей, основания для начисления льгот аудитор должен руководствоваться действующим таможенным законодательством.

Стоит отметить, что при проведении аудита внешнеэкономической деятельности необходимо получить достаточное количество аудиторских доказательств для подтверждения полноты и достоверности информации о деятельности проверяемой организации, требования к которым аудитор может получить из Ф3 «О бухгалтерском учете».

Нормативные акты второго уровня классификации касаются вопросов, регулирующих основные направления внешнеэкономической деятельности. Руководствуясь документами этого уровня, аудитор оценивает законность внешнеэкономических операций в соответствии с законодательством.

Внешнеэкономическая деятельность в процессе своего осуществления затрагивает законодательство различных стран - участников ВЭД. Руководствуясь нормативными документами третьего уровня, аудитор обязан принимать во внимание положения Конвенции ООН о договорах международной купли - продажи товаров, на основании которых он может сделать вывод о том, что право собственности на товар переходит на основе закона страны в силу достигнутой сторонами договоренности о применимом праве или закона, признаваемого таковым компетентным судом на основе коллизионных норм, которые он сочтет применимыми. При этом на основе 
межправительственных соглашений об избежании двойного налогообложения аудитор может оценить законность исполнения или неисполнения организацией функций налогового агента при оценке внешнеэкономической деятельности.

Руководствуясь документами четвертого уровня, аудитор, изучая внутриведомственные нормативные документы, может дать оценку законности внешнеэкономических операций, учитывая ведомственную специфику.

Стоит отметить, что нормативные акты четвертого уровня содержат также классификации форм первичных документов, на основании которых аудитор определяет законность оформления и отражения сделки в бухгалтерском учете.

При заключении внешнеэкономических контрактов могут использоваться международные правила, относящиеся к пятому уровню. Следует отметить, что документы пятого уровня не являются обязательными к исполнению в отличии от документов предыдущих четырех уровней рассматриваемой классификации и за их неприменение к организациям не применяются штрафные санкции. Аудитор должен принимать во внимание, что отсутствие во внешнеэкономическом контракте общепринятых условий, закрепленных правилами ИНКОТЕРМС, служит основанием для отнесение операций к рискованным. При этом аудитор должен учитывать, что сторонами во внешнеторговом контракте должна быть сделана четкая ссылка на применяемый вариант ИНКОТЕРМС.

Как показывает рисунок 6 последний шестой уровень классификации содержит внутрифирменные документы организации - участника ВЭД, отражающие проведение операций внешнеэкономической деятельности.

Проверяя документы шестого уровня, аудитор должен удостовериться в том, что внутрифирменные приказы и распоряжения соответствуют и не противоречат нормам действующего законодательства.

Следует отметить, что особенность информационной базы аудита внешнеэкономической деятельности вызвана ее спецификой и включает в себя различные данные о хозяйственной деятельности клиента. При этом различные 
группы информации различаются в зависимости от поставленных перед аудитором целей, которые определяют методы, приемы и способы достижения конечного результата.

Зависимость элементов, отражающих сущность процесса аудита от его критериев можно представить с помощью рисунка 7.

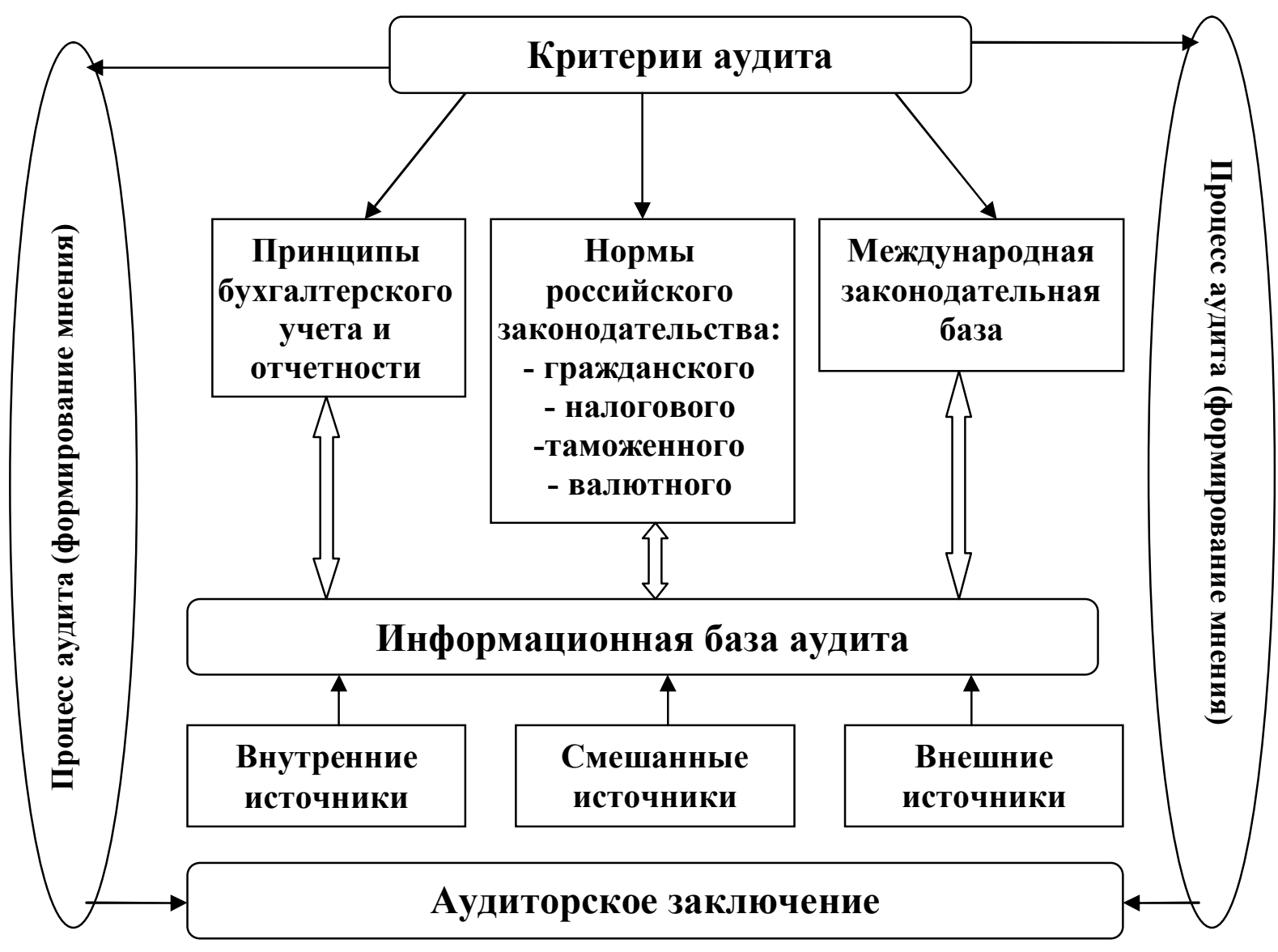

Рис. 7. Сущность процесса аудита [23]

Анализируя рисунок 7, можно сделать вывод, что сущность процесса аудита заключается в экспертизе, сравнении установленных Федеральным законом «Об аудиторской деятельности» критериев аудита с данными о совокупности операций клиента, отраженными в различных источниках информации. При этом заключительным результатом процесса проведения аудита является выражение мнения, фиксируемого в аудиторском заключении.

Стоит отметить, что классификация информационной базы для проведения аудита с учетом всех ключевых аспектов внешнеэкономической деятельности необходима для разработки основных направлений методики аудита внешнеэкономической деятельности. 
Осуществляя классификацию информации для аудита, целесообразно использовать системный подход с разделением всех источников на внутренние и внешние.

\section{Контрольные вопросы}

1. Нормативное регулирование внешнеэкономической деятельности.

2. Правовые основы аудиторской деятельности при проверке внешнеэкономических операций.

3. Критерии проведения аудита внешнеэкономической деятельности.

4. Права, обязанности и ответственность экономических субъектов при аудите внешнеэкономической деятельности.

5. Нормативное регулирование аудита внешнеэкономической деятельности.

6. Стандартизация аудиторской деятельности в РФ в области аудита внешнеэкономической деятельности.

7. Сравнительная характеристика международных и российских стандартов аудиторской деятельности.

8. Права, обязанности и ответственность аудиторов при аудите внешнеэкономической деятельности.

9. Контроль качества аудиторской деятельности при проведении аудита внешнеэкономической деятельности.

10. Требования к уровню профессионализма аудиторов в области внешнеэкономической деятельности.

\section{Примеры решения задач}

\section{Задача № 1}

Фирма «Карина» по результатам финансово-хозяйственной деятельности за 2009 г. имела выручку от реализации 42716 тыс. руб.; сумма активов баланса на 1 января 2010 г. составила 14740 тыс. руб.

Определить, подлежит ли обязательной аудиторской проверке 
бухгалтерская отчетность за 2009 г. фирмы «Карина». Ответ обоснуйте.

\section{Решение}

Бухгалтерская отчетность фирмы «Карина» за 2009 г. не подлежит обязательной аудиторской проверке, так как в соответствии с требованиями Ф3 «Об аудиторской деятельности» № 307 - ФЗ от 30.12.2008 г. результаты ее деятельности не соответствуют критериям обязательного аудита, предусмотренных п. 3 ст. 5 Ф3 «Об аудиторской деятельности» № 307 - Ф3.

\section{Задача № 2}

Аудитор, у которого заключен договор на долговременное обслуживание, не получил оплату за проведенную в прошлом году проверку. Он поставил условие, что если работа не будет оплачена, он не приступит к проверке бухгалтерской отчетности за текущий год. Клиент ответил, что результаты проверки за этот год имеют критическое значение, поскольку в случае несвоевременного получения заключения или получения модифицированного заключения фирма не сможет получить дополнительное финансирование. После выполнения проверки за этот год аудитор получит всю оплату за два года. Определите, какого рода проблема независимости станет перед аудитором, если он решит проводить проверку в этих условиях.

\section{Решение}

В данном случае аудитор оказывается в финансовой зависимости от фирмы. При проверке не должно быть установки на результат, как это происходит в данном случае, когда аудитору говорят, что дополнительное финансирование зависит от вида полученного аудиторского заключения (поскольку в случае несвоевременного получения заключения или получения модифицированного заключения фирма не сможет получить дополнительного финансирования). В данном случае аудитору можно порекомендовать получить оплату за выполненную работу и в дальнейшем отказаться от отношений с данным клиентом. 


\section{Задачи для самостоятельного решения}

\section{Задача № 1}

В 2009 г. фирма «Константа» перерегистрировалась в открытое акционерное общество. Объем реализации составил 58161 тыс. руб. Сумма активов баланса на 1 января 2010 г. составила 21115 тыс. руб.

Установите, подлежит ли обязательной аудиторской проверке финансовая отчетность фирмы «Константа» за 2009 г.

\section{Задача №2}

Фирма «Константинополь» в октябре 2009 г. обратилась в аудиторскую фирму с предложением заключить договор о предоставлении услуг по восстановлению аналитического учета за 2008 г. Договор был заключен, услуги оказаны и оплачены. Через месяц эта фирма обратилась в аудиторскую фирму с предложением заключить договор на предоставление услуг по подтверждению бухгалтерской отчетности за 2008 г.

Установить, примет ли данное предложение аудиторская фирма. Может ли аудиторская фирма заключить договор на оказание услуг по подтверждению бухгалтерской отчетности фирмы «Константинополь» за 2009 г.

\section{Задача № 3}

Вы аудитор фирмы « Весна ». Ваша фирма желает переехать в другой офис, и фирма «Весна» предлагает вам очень удобное помещение в здании, собственником которого она является.

Определите, какие проблемы возникают в связи с этим предложением.

\section{Задача № 4}

Фирма «Глазго» с целью расширения производственной деятельности обратилась в банк с просьбой в январе 2010 г. предоставить ей кредит. Банк запросил бухгалтерскую отчетность организации за 2009 г. и аудиторское заключение о ее достоверности. Фирма «Глазго» в соответствии с положением о критериях обязательности подтверждения бухгалтерской отчетности независимыми экспертами не подлежит обязательной аудиторской проверке. Однако в ноябре 2009г. в организации была проведена документальная 
проверка налоговой инспекцией. Фирма «Глазго» предлагает акт документальной проверки налоговой инспекции использовать в качестве подтверждения достоверности бухгалтерской отчетности.

Определите, примет ли данное предложение банк для предоставления коммерческого кредита на цели развития производства фирме «Глазго».

\section{Задача № 5}

Аудиторская фирма получила два предложения по проведению проверок: от фирмы «Анталио» и от фирмы «Лассеро».

Фирма «Анталио» существует на рынке более пяти лет, обязательной аудиторской проверке в соответствии с критериями не подлежит. По результатам документальной проверки налоговыми органами на фирму были наложены штрафные санкции. Погашение задолженности перед бюджетом по штрафным санкциям приведет к нарушению финансовой устойчивости организации. Поэтому фирма «Анталио» решила обратиться в аудиторскую фирму с целью уменьшения объема штрафных санкций, наложенных налоговой инспекцией. Фирма «Анталио» предлагает заплатить за услуги аудиторской фирме 1000 руб.

Фирма «Лассеро» существует на рынке три года. Как предприятие с участием иностранного капитала она подлежала обязательной аудиторской проверке. Но в этом году фирма «Лассеро» решила изменить аудиторскую фирму и обратилась с предложением о заключении договора на проверку бухгалтерской отчетности в названную выше аудиторскую фирму. Фирма «Лассеро» предлагает за услуги по договору заплатить аудиторской фирме 800 руб.

Аудиторская фирма имеет ограничения в штатных сотрудниках. При условии заключения договоров по двум предложениям ей необходимо привлекать внештатных сотрудников.

Определите, следует ли принимать аудиторской фирме оба предложения, если необходимо принять одно, то какое.

\section{Задача № 6}

Один из учредителей фирмы «Краско» требует заключить договор с 
аудиторской фирмой на оказание услуг по проверке правильности организации бухгалтерского учета с целью дать обоснование отстранению от занимаемой должности генерального директора. Объем платы за услуги учредитель предлагает определить в зависимости от степени достижения поставленной цели. Установите действия аудиторской фирмы.

\section{Контрольные тесты}

1. Федеральные правила (стандарты) аудиторской деятельности являются обязательными:

а) только для аудиторских организаций и индивидуальных аудиторов;

б) только для аудируемых лиц;

в) для аудиторских организаций, индивидуальных аудиторов и аудируемых лиц, за исключением положений, которые носят рекомендательный характер;

г) для аудиторских фирм и аудируемых лиц.

2. Укажите верный ответ: документ, регулирующий аудит в РФ - это:

а) Федеральный закон «Об аудите в РФ».

б) Федеральные правила (стандарты) аудиторской деятельности в РФ.

в) Постановление Правительства об аудите.

г) Федеральный закон «О бухгалтерском учете в РФ».

3. Установите соответствие:

Уровни нормативного Документы:

регулирования аудита:
a) Первый
А. Внутренние стандарты
б) Второй
Б.Федеральный закон «Об аудиторской деятельности»
в) Третий
В.Национальные стандарты
г) Соответствия отсутствуют 


\section{Глава 5. Основные этапы, техника и технология проведения аудиторской проверки внешнеэкономической деятельности}

\section{1. Преддоговорные отношения между аудиторами и аудируемыми лицами}

Аудиторская проверка должна отвечать определенному набору требований и состоять из определенных этапов.

Условно аудиторскую проверку можно разбить на три основных этапа:

1) планирование;

2) сбор аудиторских доказательств;

3) завершение аудита.

На первом этапе аудитор:

- предварительно знакомится с клиентом;

- оформляет свои отношения с клиентом договором и (или) письмомобязательством;

- рассчитывает уровень существенности предстоящей проверки;

- изучает и оценивает систему бухгалтерского учета и внутреннего контроля организации клиента;

- оценивает аудиторские риски;

- готовит общий план и программу аудита.

На втором этапе (основном), занимается сбором аудиторских доказательств, для чего выполняет аудиторские процедуры. Аудиторские процедуры включают в себя тестирование средств контроля и аудиторские процедуры по существу. Последние в свою очередь подразделяются на детальную проверку правильности отражения в бухгалтерском учете оборотов и сальдо по счетам и аналитические процедуры.

На последнем этапе аудитор должен:

- завершить подготовку рабочей документации;

- подготовить письменную информацию руководству проверяемого 
экономического субъекта по результатам аудита;

- сформулировать мнение о достоверности бухгалтерской отчетности проверенного экономического субъекта;

- подготовить по установленной форме аудиторское заключение.

При проведении аудита внешнеэкономической деятельности можно выделить следующую последовательность проведения проверки:

1. Первичное ознакомление.

2. Определение объема работы, корректировка плана.

3.Утверждение плана работы, определение количества человек, принимающих участие в проверке.

4. Выход на объект, начало работы.

5. Беседа с главным бухгалтером по объектам аудита.

6. Запрос документов по списку у проверяемого предприятия.

7. Проверка полноты полученных документов.

8. Изучение документов.

9. Осуществление выборок.

10. Проведение аналитических процедур.

11. Формирование рабочей документации.

12. Уточнение информации по представленным документам.

13. Выявление ошибок и определение уровня их существенности.

14. Обсуждение ошибок с ответственными лицами и принятие решения о соответствии бухгалтерского оформления сущности выполняемых операций.

15. Предупреждение предприятия о возможной ответственности за нарушение валютного и иного законодательства.

16. Совместная работа над ошибками, исправление которых необходимо и возможно в течение аудиторской проверки.

17. Подготовка рекомендаций и оформление результатов работы.

Таким образом, начальной стадией аудита является предварительное планирование аудиторской проверки, которое осуществляется до написания письма-обязательства и до заключения соответствующего договора, так как 
сначала аудитор должен принять решение о возможности аудита или об отказе в его проведении.

Основная цель предварительного планирования - оценить планируемый объем аудиторской проверки, количественный и качественный состав специалистов, предполагаемые сроки проверки, исходя из которых будет определяться стоимость аудиторских услуг. На этапе предварительного планирования аудиторская фирма определяет степень своего доверия к системе бухгалтерского учета и внутреннего контроля организации, что может существенно повлиять на объем аудиторских процедур и, соответственно, стоимость проверки [27].

Для организации процедура аудиторской проверки должна начинаться с выбора и утверждения аудиторской фирмы.

В настоящее время в РФ действует большое количество российских аудиторских фирм и перед экономическими субъектами стоит проблема выбора. Самый простой способ выбрать аудиторскую фирму - через рекламу, однако это и самый ненадежный способ.

Часто экономические субъекты используют рекомендации деловых друзей, партнеров, знакомых или черпают информацию из специальной литературы, семинаров, выставок и пр.

К числу основных критериев отбора аудиторских фирм относятся:

- численность персонала и его опыт;

- оборот фирмы;

- наиболее крупные клиенты фирмы;

- уровень цен на услуги;

- возможные предоставляемые льготы;

- ответственность за качество аудита;

- наличие филиалов в регионах;

- стаж работы на рынке;

- наличие соответствующей лицензии;

- ассортимент предоставляемых услуг. 
Численность персонала и оборот аудиторской фирмы можно узнать из регулярно публикуемых в прессе рейтингов аудиторских фирм.

Поскольку в условиях рынка цена на услуги различна в разных фирмах, экономические субъекты имеют возможность выбора аудиторских фирм и по этому параметру.

Некоторые аудиторские фирмы предоставляют своим постоянным клиентам определенные льготы в цене на услугу, времени оказания услуги, предоставлению конкретных аудиторов и т.д. Этот фактор также следует учитывать при выборе аудиторской фирмы. Аудиторские фирмы в своих рекламных буклетах или в другой форме перечисляют наиболее известных своих клиентов для дополнительного подтверждения своего статуса, солидности и значимости на рынке аудиторских услуг.

Важным критерием для выбора аудиторской фирмы является та степень ответственности за качество своей работы, которую аудиторская фирма готова взять на себя по договору на проведение аудита, тем более, что размер ответственности, которую согласна взять на себя аудиторская фирма по договору на аудит, имеет очень широкий диапазон.

Время работы на рынке аудиторских услуг также является хорошим критерием, т.к. свидетельствует об имеющемся опыте.

Наличие филиалов в регионах является лишь вспомогательным критерием в тех случаях, когда это важно для экономического субъекта.

Конечно, экономическому субъекту следует убедиться в том, что аудиторская фирма имеет разрешение на соответствующий вид услуг, и это разрешение является не просроченным.

Чем шире ассортимент услуг, которые предоставляет аудиторская фирма, тем удобнее экономическому субъекту т.к. при необходимости в одном месте можно получить исчерпывающую информацию по решению той или иной проблемы.

В предусмотренных законом случаях утверждение аудитора является прерогативой общего собрания участников (акционеров) организации. При 
этом установление размера оплаты аудиторских услуг относится к исключительной компетенции Совета директоров.

Важным условием во все случаях аудита, если его результаты должны будут оформлены официальным заключение, является независимость аудитора.

Независимость аудиторской фирмы от проверяемой организации рассматривается с точки зрение как формальных, так и фактических обстоятельств. Независимость аудита обеспечивается установлением перечня отношений между ним и проверяемой организацией, при которых аудиторы не имеют права проводить обязательный аудит этих организаций.

Чтобы снизить риск неудачи аудиторской проверки, аудиторы и аудиторские фирмы должны проводить продуманную политику оценки потенциальных клиентов. Это особенно важно в период когда нередки нарушения действующих правил ведения бухгалтерского учета и составления отчетности.

Неудачный выбор клиента может привести к значительным финансовым и моральным издержкам, нанести ущерб имиджу фирмы и аудитора.

К основным процедурам отбора клиентов можно отнести:

1. Оценка характера отрасли.

2. Оценка цели аудиторской проверки данного клиента и возможного использования ее результатов.

3. Выяснение особенностей руководства потенциального клиента.

4. Предварительная оценка потенциальной трудоемкости и сложности аудита, а также аудиторского риска.

5. Оценка причины смены или смен аудиторов.

6. Знакомство с оговорками прежних аудиторских заключений о результатах аудита.

7. Выяснение характера и проблем взаимоотношений с налоговыми органами, банками, партнерами, акционерами и другими пользователями информации, финансовой отчетности потенциального клиента.

8. Получение рекомендаций (например, от различных организаций, 
профессионалов и т.д.).

9. Аналитическая проверка отчетности.

10. Предварительное знакомство с состоянием бухгалтерского учета и отчетности, а также с текущими и предстоящими проблемами потенциального клиента.

11. Оценка собственной способности - аудиторской фирмы или аудитора выполнить работу (наличие соответствующего персонала, знание отрасли клиента и т.д.).

Если результаты перечисленных или других процедур обнаруживают высокий риск аудита или задача оказывается слишком сложной для аудитора, клиент не принимается для обслуживания.

После того, как была выбрана аудиторская фирма для проведения аудита внешнеэкономической деятельности и определен потенциальный клиент, между ними начинаются преддоговорные отношения, заключающиеся в согласовании основных условий договора, руководствуясь требованиями Федерального правила (стандарта) №12 «Согласование условий проведения аудита», разработанного с учетом международных стандартов аудита.

Аудитор и руководство аудируемого лица должны достичь согласия в отношении условий проведения аудита. Согласованные условия необходимо отразить документально в договоре оказания аудиторских услуг.

Аудитор может использовать в ходе достижения договоренности с руководством аудируемого лица письмо о проведении аудита - документ, направляемый аудитором предполагаемому аудируемому лицу и подписываемый руководством аудируемого лица в случае согласия с основными условиями задания по проведению аудита.

Предполагаемая форма письма о проведении аудита приведена в приложении 2.

Несмотря на то, что цели и объем аудита, а также обязанности аудитора установлены законодательством Российской Федерации, аудитору рекомендуется включить эти положения в договор или в предшествующее 
договору письмо о проведении аудита.

Форма и содержание писем о проведении аудита для различных аудируемых лиц могут иметь особенности, но, как правило, в письме о проведении аудита указываются:

1. цель аудита финансовой (бухгалтерской) отчетности;

2. ответственность руководства аудируемого лица за подготовку и представление финансовой (бухгалтерской) отчетности;

3. объем аудита, включая ссылки на законодательство Российской Федерации и федеральные правила (стандарты) аудиторской деятельности;

4. аудиторское заключение и любые иные документы, которые предполагается подготовить по результатам аудита;

5. информация о том, что в связи с применением в ходе аудита выборочных методов тестирования и другими свойственными аудиту ограничениями, наряду с ограничениями, присущими системам бухгалтерского учета и внутреннего контроля аудируемого лица, имеется неизбежный риск того, что некоторые, в том числе существенные, искажения финансовой (бухгалтерской) отчетности могут остаться необнаруженными;

6. требование обеспечения свободного доступа ко всей бухгалтерской документации и другой информации, запрашиваемой в ходе проведения аудита;

7. цена проведения аудита (либо способ ее определения), а также порядок признания услуги оказанной и порядок расчетов.

В письме о проведении аудита могут также быть указаны:

1. договоренности, связанные с координацией работы аудитора и сотрудников аудируемого лица в ходе планирования аудита;

2. право аудитора получить от руководства аудируемого лица официальные письменные заявления, сделанные в связи с аудитом;

3. обязательство руководства аудируемого лица содействовать в направлении запросов кредитным организациям и контрагентам аудируемого лица с целью получения информации, необходимой для 
проведения аудита;

4. обязательство руководства аудируемого лица обеспечить присутствие сотрудников аудитора при проведении инвентаризации имущества аудируемого лица;

5. общие сведения об оказываемых аудиторской организацией услугах, квалификации персонала, наиболее крупных клиентах, членстве в российских и международных аудиторских организациях и союзах;

6. примерный календарный план проведения аудита и состав направляемой группы аудиторов;

7. общую характеристику применяемых методов проведения проверки;

8. условия оплаты аудита.

При необходимости в письме о проведении аудита или приложениях к нему могут быть также приведены:

1. договоренность о привлечении к работе по каким-либо вопросам аудита других аудиторов и экспертов;

2. договоренность о привлечении к совместной работе внутренних аудиторов, а также других сотрудников аудируемого лица;

3. договоренности, способствующие взаимодействию предполагаемого аудитора с предшествующим аудитором (при его наличии);

4. любые ограничения ответственности аудитора в соответствии с законодательством Российской Федерации и федеральными правилами (стандартами) аудиторской деятельности;

5. информация о любых дополнительных соглашениях между аудитором и аудируемым лицом;

6. рекомендации по использованию аудиторского заключения по назначению;

7. предложение о дальнейшем развитии договорных отношений между аудиторской организацией и экономическим субъектом.

Если аудитор головной организации является также аудитором дочерних 
организаций, то на решение аудитора о том, заключать ли отдельный договор оказания аудиторских услуг с указанными дочерними организациями (направлять ли отдельное письмо о проведении аудита), влияют следующие факторы:

1. порядок назначения аудитора дочерних организаций;

2. необходимость составления отдельного аудиторского заключения по дочерней организации;

3. требования законодательства Российской Федерации;

4. объем работы, выполненной другими аудиторами;

5. доля собственности головной организации;

6. степень независимости руководства дочерней организации от головной организации.

В случае повторяющихся на протяжении ряда лет аудиторских проверок аудитор должен решить, есть ли необходимость пересмотреть условия аудиторского задания или напомнить аудируемому лицу о существующих условиях задания.

Аудитор может принять решение не составлять каждый раз новое письмо о проведении аудита. Однако следующие факторы могут сделать целесообразным составление нового письма:

1. любой признак, указывающий на неправильное понимание аудируемым лицом цели и объема аудита;

2. любые пересмотренные или особые условия аудиторского задания;

3. кадровые изменения в высшем руководстве, Совете директоров или в структуре аудируемого лица;

4. изменения в структуре собственности аудируемого лица;

5. значительные изменения характера или масштабов деятельности аудируемого лица;

6. требования законодательства Российской Федерации.

В случае, если аудируемое лицо до завершения выполнения аудиторского задания обратится к аудитору с просьбой изменить его условия на условия, 
предусматривающие более низкий уровень уверенности в достоверности финансовой (бухгалтерской) отчетности, чем разумная уверенность, аудитор должен рассмотреть целесообразность такого изменения.

Просьба аудируемого лица к аудитору об изменении аудиторского задания может быть вызвана изменением обстоятельств, влияющих на необходимость оказания услуги, неправильным пониманием характера аудита или сопутствующих услуг, запрашиваемых изначально, или ограничением объема аудита, устанавливаемым руководством аудируемого лица или связанным с другими причинами. Аудитору необходимо тщательно изучить причину данной просьбы и возможные последствия ограничения объема аудита.

Изменение обстоятельств, влияющих на требования аудируемого лица, или неправильное понимание характера услуги, запрашиваемой изначально, обычно рассматривается как обоснованная причина просьбы об изменении задания. Изменение аудиторского задания не может рассматриваться как обоснованное, если оно вызвано неточной или неполной информацией.

Прежде, чем согласиться на изменение условий аудиторского задания, которое может привести к замене аудита сопутствующими аудиту услугами, аудитор должен рассмотреть возможные правовые последствия таких изменений.

Если аудитор придет к заключению о том, что изменение условий аудиторского задания обоснованно, а также, если работа аудитора соответствует федеральным правилам (стандартам) аудиторской деятельности, которые могут быть применены к измененному заданию, то отчет или заключение должны соответствовать пересмотренным условиям задания. Во избежание введения в заблуждение пользователя в отчет или заключение не должны включаться ссылки на:

1. первоначальное задание;

2. любые процедуры, которые могли быть выполнены в соответствии с первоначальным заданием, за исключением 
случаев, если задание меняется на задание о согласованных процедурах и, следовательно, ссылка на проведенные процедуры составляет один из элементов соответствующего отчета.

При изменении условий задания аудитору и его клиенту, ранее являвшемуся аудируемым лицом, необходимо согласовать новые условия.

Аудитор не должен соглашаться на изменение условий задания при отсутствии разумного обоснования.

Если аудитор не может согласиться на изменение аудиторского задания на иное задание и аудируемое лицо возражает против продолжения работы в соответствии с первоначальным заданием, то аудитор должен отказаться от выполнения задания или рассмотреть вопрос о необходимости сообщить о возникшей ситуации заинтересованным лицам.

Стоит отметить, что письму-обязательству должно предшествовать официальное предложение экономического субъекта с просьбой об оказании аудита и (или) сопутствующих ему услуг.

Письмо-обязательство направляется исполнительному органу экономического субъекта до заключения договора на проведение аудита во избежание неправильного понимания им условий предстоящего договора.

Экономический субъект должен письменно подтвердить согласие на условия аудита, предложенные аудиторской организацией. Если подтверждение получено, то условия письма остаются в силе в течение действия соглашения о проведении аудиторской проверки.

Если цель и масштаб аудита определены между сторонами в долгосрочном договоре, то письмо-обязательство может не составляться, либо его содержание должно представлять дополнительную информацию для экономического субъекта.

Письмо-обязательство аудиторской организации, направленное экономическому субъекту, документально подтверждает согласие на проведение аудита или принятие предложения о назначении ее официальным аудитором этого экономического субъекта. 
До начала проведения аудита или оказания сопутствующих услуг аудиторская организация должна ознакомиться в достаточной мере с деятельностью экономического субъекта. При проведении аудита бухгалтерской отчетности аудиторская организация должна понимать деятельность проверяемого экономического субъекта в достаточной степени, чтобы идентифицировать и правильно оценивать события, операции, используемые методы учета, которые могут оказывать существенное влияние на достоверность бухгалтерской отчетности, на ход проведения проверки или на выводы, содержащиеся в аудиторском заключении.

Факторами, определяющими необходимость понимания деятельности экономического субъекта, являются:

- экономическая политика экономического субъекта в отчетный период (периоды), ее стратегии и тактики;

- проводимая экономическим субъектом учетная политика и ее соответствие направлениям финансовой политики;

- идентификация хозяйственных операций, осуществляемых экономическим субъектом; возможность качественного проведения аудита;

- правильность применения нормативно-правовых актов, регулирующих операции, проводимые экономическим субъектом;

- обоснованность выводов о достоверности бухгалтерской отчетности экономического субъекта.

Областями деятельности экономического субъекта, понимание которых существенно для аудиторской организации на всех стадиях проведения аудита, являются:

- основная деятельность;

- инвестиционная деятельность;

- прочие операции, в том числе внереализационные.

Приобретение знаний о деятельности экономического субъекта представляет собой непрерывный процесс сбора и обработки информации на всех стадиях проведения аудита. При этом информация, получаемая на 
последующих стадиях, дополняет и уточняет данные, полученные на предыдущих стадиях.

Понимание деятельности экономического субъекта, необходимое для работы, включает понимание экономической ситуации в стране и в отрасли, в которой действует экономический субъект, а также более подробное знание того, как он действует. Понимание деятельности экономического субъекта, требуемое от аудиторской организации, может быть менее глубоким, чем это необходимо для управления экономическим субъектом.

Факторы, влияющие на финансово-хозяйственную деятельность экономического субъекта, можно разделить на внешние факторы - общие экономические и отраслевые факторы.

Понимание деятельности экономического субъекта зависит от квалификации аудитора, который участвует в проведении аудита и должен быть по возможности достаточным для качественного проведения проверки. До начала проверки аудиторская организация должна в целом понимать влияние на деятельность проверяемого субъекта внешних факторов, тогда как детальный анализ внутренних факторов возможен в процессе проведения аудита.

До проведения проверки аудиторская организация должна получить первоначальные знания особенностей отрасли, права собственности, управления и операций экономического субъекта, подлежащего аудиту, и оценить их достаточность в понимании деятельности экономического субъекта для проведения аудита. Полученные знания она обязана использовать при планировании аудита.

Пополнение информации, необходимой для углубления понимания деятельности экономического субъекта, осуществляется на всех стадиях аудита как руководителем аудиторской проверки, так и членами аудиторской группы; при этом руководитель должен в данном вопросе предъявлять к членам аудиторской группы достаточно высокие требования.

При повторных аудиторских проверках экономического субъекта 
аудиторская организация может откорректировать и переоценить информацию, собранную ранее. Аудиторская организация должна также выполнить процедуры для выявления существенных изменений, произошедших со времени проведения последней аудиторской проверки в тех явлениях и процессах, которые отражаются этой информацией.

Руководители проверяемого экономического субъекта обязаны обеспечить полное и своевременное представление информации, необходимой для понимания деятельности этого экономического субъекта. Получение такой информации должно быть предусмотрено в общем плане аудита, при этом следует указать на возможность получения необходимой дополнительной информации.

Основными методами получения знаний о деятельности экономического субъекта являются:

- изучение общеэкономических условий деятельности проверяемого экономического субъекта (например, национальная экономическая политика, система налогообложения и таможенного контроля, установление лимитов и КвОт);

- анализ региональных особенностей, влияющих на деятельность экономического субъекта (например, географическое положение, экономические и налоговые условия региона);

- учет отраслевых особенностей сферы деятельности экономического субъекта;

- знакомство с организацией и технологией производства;

- сбор информации о персонале экономического субъекта, ассортименте выпускаемой продукции, применяемых методах ведения бухгалтерского учета (форма, учетная политика, степень автоматизации);

- сбор информации о структуре собственного капитала, анализ размещения и котировок акций;

- сбор информации об организационной и производственной структурах, проводимой маркетинговой политике, основных поставщиках и покупателях; 
- анализ деятельности экономического субъекта на рынке ценных бумаг (например, выдача векселей, операции с финансовыми векселями, покупка и продажа акций);

- учет наличия взаимоотношений с филиалами и дочерними (зависимыми) обществами и методов консолидации финансовой отчетности, порядка распределения прибыли, остающейся в распоряжении организации;

- сбор информации о юридических и финансовых обязательствах экономического субъекта (имеет важное значение на этапе планирования при определении уровня существенности и расчета внутрихозяйственного риска);

- знакомство с организацией системы внутреннего контроля.

При выявлении аспектов деятельности экономического субъекта, которые требуют специальных знаний, аудитор может пригласить эксперта.

В целях получения наиболее глубоких знаний о деятельности экономического субъекта аудитор применяет аналитические процедуры.

Аудитор может получить знания о деятельности экономического субъекта из следующих источников:

- официальные публикации в юридических изданиях, профессиональных, отраслевых и региональных журналах и монографиях;

- статистические данные, официальные отчеты экономических субъектов, банковские отчеты;

- нормативные и законодательные акты, регламентирующие деятельность проверяемого экономического субъекта;

- результаты посещения специальных семинаров, конференций, других аналогичных мероприятий;

- разъяснения и подтверждения, полученные от персонала проверяемого экономического субъекта, беседы с внутренним аудитором и другими компетентными лицами;

- запросы третьим лицам;

- консультации с аудитором, который проводит аудит в предыдущие периоды; 
- учредительные документы, протоколы собраний совета директоров и акционеров, контракты и договоры, бухгалтерская отчетность прошлых периодов, планы и бюджеты, положение о бухгалтерии, учетной политике, документообороте; рабочий план счетов и проводок; схема организационной и производственной структур;

- осмотр цехов, складов и служб проверяемого экономического субъекта, а также опрос персонала, непосредственно не связанного со сферой учета;

- результаты проведения аналитических процедур; выполнение необычных хозяйственных операций, порядок оформления которых неоднозначно трактуется действующим законодательством;

- идентификация филиалов и структурных подразделений, выделенных на отдельный баланс; хозяйственных операций, методов учета и налогообложения в них;

- результаты работы с привлеченными специалистами-экспертами;

- знакомство с реестром акционеров;

- использование знаний, накопленных из предыдущего опыта аудитора;

- материалы налоговых проверок и судебных процессов.

Перед аудиторской проверкой и в ходе ее проведения все произведенные процедуры и полученная информация отражаются в рабочих документах аудитора.

Знание сущности деятельности экономического субъекта должно быть использовано аудиторской организацией на всех стадиях проведения аудита в целях:

- квалифицированного выбора экономического субъекта для проведения аудита;

- рационального планирования аудита;

- эффективного проведения аудита;

-определения аудиторского риска и его составляющих, а также уточнения уровня существенности;

- оценки системы внутреннего контроля; 
- выбора видов и методов выполнения аналитических процедур;

- оценки и обоснования получаемых аудиторских доказательств;

-оценки допущения непрерывности деятельности экономического субъекта;

- определения областей, где могут потребоваться специальные аудиторские знания;

- определения третьих сторон и операций, связанных с третьими сторонами;

- выявления противоречивой информации;

- достижения высокой степени профессионализма при опросах и обслуживании экономического субъекта;

- в других целях.

Аудиторская организация может документировать и систематизировать знания о деятельности экономического субъекта в виде постоянных файлов, в том числе в автоматизированном виде. В состав постоянного файла могут входить:

- история развития экономического субъекта;

- перечень осуществляемых видов деятельности;

- положения учетной политики и ее последовательные изменения;

- другая информация, имеющая значение не только для последующего аудита проверяемого в настоящий момент экономического субъекта, но и для будущих аудиторских проверок.

При комплектации постоянного файла аудиторская организация должна следить за его периодическим пополнением и обновлением по итогам аудиторских проверок данного экономического субъекта.

\section{2. Порядок заключения договоров на оказание аудиторских услуг}

После того, как аудитор и его клиент оговорили основные условия проверки в письме - обязательстве, оформляется и заключается договор на проведение аудита.

В аудиторской деятельности используются различные виды договоров: на 
проведение аудита, на абонентское обслуживание, консультационноинформационное обслуживание и др.

Договор на проведение аудиторской проверки является официальным документом, регламентирующим взаимоотношения между аудиторской организацией и экономическим субъектом. В принципе договор на проведение аудита ничем не отличается от обычных договоров предпринимательской деятельности. Как и другие договоры, он юридически отражает и фиксирует согласованные интересы сторон-участниц, в данном случае заказчика-клиента и исполнителя-аудитора. Однако договор на аудит имеет и существенное отличие от других договоров в предпринимательстве.

Перед подписанием договора аудитору необходимо стремиться не только уяснить себе желание клиента, но и по возможности постараться помочь ему правильно сформулировать свой заказ. Качество проведения аудиторской проверки, бесконфликтные взаимоотношения аудитора с клиентом во многом зависят от того, какой договор на проведение аудита будет заключен.

Подготовка договора начинается после предварительного ознакомления с деятельностью экономического субъекта и принятия решения о возможности оказания аудиторских услуг.

Этап подготовки договора включает в себя определение трудоемкости, стоимости и сроков проведения аудита, потребности в привлечении консультантов и экспертов.

Договор на оказание аудиторских услуг может носить разовый характер.

В случае повторного соглашения об оказании аудиторских услуг условия договора могут пересматриваться и должны оформляться в письменном виде.

Договор может быть заключен на длительный срок. Предметом такого договора могут выступать одновременно аудиторские услуги и сопутствующие аудиторские услуги, не запрещенные законодательством в области аудита.

Если договор не сопровождается письмом-обязательством, то в тексте договора должно излагаться подробное описание условий будущего сотрудничества, прав и обязанностей сторон. 
Договор оформляется в соответствии с требованиями Гражданского кодекса Российской Федерации. (Приложение 3)

Текст договора должен в обязательном порядке содержать пункты, раскрывающие следующие аспекты:

- предмет договора на оказание аудиторских услуг;

- условия оказания аудиторских услуг;

- права и обязанности аудиторской организации;

- права и обязанности экономического субъекта;

- ответственность сторон и порядок разрешения споров;

- стоимость аудиторских услуг и порядок оплаты.

Наряду с этим текст договора может содержать другие, важные для сторон, обстоятельства. Договор должен содержать следующие обязательные пункты, раскрывающие условия аудиторских услуг:

- цель оказания услуг и объект (в частности, при проведении аудита указывается порядок аудита филиалов и подразделений экономического субъекта, а также его дочерних компаний в случае их наличия);

- сроки и этапы проведения оказания аудиторских услуг;

- ссылки на законодательные акты и нормативные документы, на основании которых оказаны аудиторские услуги.

Договор должен содержать следующие обязательные пункты, раскрывающие права и обязанности аудиторской организации:

- неукоснительное соблюдение при оказании аудиторских услуг требований законодательства Российской Федерации;

- самостоятельное определение форм и методов аудиторской проверки, исходя из требований нормативных актов Российской Федерации;

- при проведении аудита проверка любой документации экономического субъекта, необходимой для проведения аудита, а также получение разъяснений и дополнительных сведений по возникшим в ходе проверки вопросам;

- при проведении аудита получение по письменному запросу необходимой для осуществления аудиторской проверки информации от третьих 
лиц, в том числе государственных органов;

- отказ от проведения аудиторской проверки в случае непредставления проверяемым экономическим субъектом необходимой документации.

- доступ в систему компьютерной обработки данных;

- обращение к консультанту или эксперту в случае выявления такой необходимости;

- распоряжение своей рабочей документацией;

- необходимость привлечения к участию в проверке дополнительных аудиторов (специалистов) в связи со значительным объемом работы или какими-либо иными обстоятельствами, возникшими после заключения договора;

- квалифицированное проведение аудиторской проверки и соблюдение конфиденциальности и коммерческой тайны;

- обеспечение сохранности документов, получаемых и составляемых в ходе аудиторской проверки, и неразглашение их содержания без согласия собственника (руководителя) экономического субъекта, за исключением случаев, предусмотренных законодательными актами Российской Федерации.

Договор должен содержать следующие обязательные пункты по правам и обязанностям экономического субъекта:

- получение информации о требованиях законодательства, касающегося проведения аудита, в том числе являющихся основаниями для замечаний, сделанных аудитором;

- создание аудитору (аудиторской фирме) условий для своевременного и полного проведения аудиторской проверки, предоставление всей необходимой документации, доступ в систему компьютерной обработки информации, а также дача по запросу аудитора разъяснений и объяснений в устной и письменной форме;

- оперативное устранение выявленных аудиторской проверкой нарушений порядка ведения бухгалтерского учета и составления бухгалтерской (финансовой) отчетности; 
- отсутствие действий с целью ограничения круга вопросов, подлежащих выяснению при проведении аудиторской проверки;

- отсутствие давления на аудиторскую организацию в любой форме с целью изменения ее мнения о достоверности бухгалтерской отчетности экономического субъекта.

Договор должен содержать следующие обязательные пункты по ответственности сторон и порядку разрешения споров:

- о полноте и достоверности представленной для аудита документации, функционировании системы внутреннего контроля;

- о качестве оказания аудиторских услуг в соответствии с законодательством Российской Федерации;

- об ответственности за частичное или полное неисполнение обязательств;

- о возможности и необходимости разрешения возникших споров путем переговоров либо в судебном порядке.

В текст договора на оказание аудиторских услуг в соответствии с пожеланиями сторон по договору могут быть включены:

- общие сведения об оказываемых аудиторской организацией услугах, квалификации персонала;

- примерный календарный план проведения аудита и состав направляемой группы аудиторов;

- общая характеристика применяемых методов проведения проверки;

- предложения об использовании услуг других аудиторов (аудиторских фирм), независимых экспертов, в тех аспектах деятельности проверяемой организации, которые аудиторская организация и экономический субъект сочтут необходимыми;

- уровень существенности возможных ошибок, устанавливаемый при проведении аудита;

- согласие экономического субъекта на использование результатов, полученных предшествующей аудиторской организацией; 
- описание важнейших ограничений ответственности аудиторской организации;

- рекомендации по использованию аудиторского заключения по назначению;

- предложения о дальнейшем развитии договорных отношений между аудиторской организацией и экономическим субъектом;

- финансовые санкции за просрочку оплаты аудиторских услуг;

- условия оплаты дополнительных расходов, возникших в ходе проверки.

При составлении договора, предусматривающего оказание сопутствующих аудиту услуг, целесообразно предусмотреть раздел, включающий уточнение содержания аудиторского задания.

Изменения или дополнительные соглашения прилагаются к договору и являются его неотъемлемой частью.

Исходя из практики работы аудиторских фирм, можно отметить следующие вопросы, которые желательно отразить в тексте договора на оказание аудиторских услуг.

В договоре на аудиторскую проверку целесообразно отразить возможность аудитора отказаться от выдачи положительного аудиторского заключения.

Нередко аудиторские фирмы включают в договор пункт о сроках предоставления клиентом документов, необходимых для проведения проверки.

В договоре желательно указывать предоплату заказчика аудиторской фирме (что с точки зрения мирового бизнеса является неэтичным). Предоплата обеспечивает финансовую независимость аудитора в процессе аудита, устраняет возможность "давления" в процессе проверки со стороны клиента путем угрозы не выплатить вознаграждение за аудит. Обычно предоплата, которую требуют аудиторские фирмы, составляет от 50 до 100\%.

Целесообразно для аудитора предусмотреть в договоре пункт, обязывающий заказчика оказывать помощь аудитору в ходе проверки. Например, выделение работников для оказания помощи при проведении 
инвентаризации, предоставление транспорта и гостиницы аудитору в случае необходимости его выезда в командировки. Кроме того, аудиторские фирмы иногда предусматривают в договоре пункты о предоставлении клиенту дополнительных конкретных услуг. Ряд фирм записывают в договоре пункт о том, что в случае отказа заказчика от договора в одностороннем порядке, он обязуется оплатить фактически проделанную работу исполнителя.

Можно указывать сумму значимой ошибки в отчетности (существенность), значимость неточностей, которые необходимо исправить, кроме того, перечень сведений, составляющий коммерческую тайну клиента, порядок зачета времени, потраченного на аудит; размер ответственности аудиторской фирмы.

Важным моментом при заключении договора на аудиторскую проверку является оценка стоимости выполнения аудита. Аудиторы стремятся к тому, чтобы не занизить и не завысить стоимость услуг, т.к. и то и другое зачастую "отпугивает", особенно если этот экономический субъект впервые обращается в данную аудиторскую фирму.

Постепенно в России складывается рынок аудиторских услуг, под воздействием которого и регулируются ставки этих услуг.

Все имеющиеся в настоящее время в Российской Федерации формы и виды оценки стоимости аудиторских услуг можно условно разделить на следующие группы:

- аккордная оплата;

- повременная оплата;

- сдельная оплата;

- комбинированная оплата.

При аккордной оплате сумма оплаты заранее определяется и фиксируется в договоре на проведение аудиторской проверки до ее начала. Некоторые аудиторские фирмы определяют ее "условно" в зависимости от финансовых возможностей клиента или, например, в размере годовой зарплаты главного бухгалтера клиента. Но уже достаточно много отечественных фирм при оценке 
стоимости работ поступают следующим образом: за определенную плату к клиенту перед заключением договора направляется аудитор, который знакомится с особенностями деятельности клиента, оценивает ориентировочный аудиторский риск и примерную трудоемкость работы. После этого аудиторская фирма определяет общую стоимость работ и заключает договор с клиентом.

К недостаткам этой формы оплаты относится невозможность обоснованно оценить реальную трудоемкость работы и предусмотреть непредвиденные обстоятельства. Если эти "непредвиденные обстоятельства" в ходе аудиторской проверки резко увеличивают еe трудоемкость, то это неблагоприятно отражается на финансовых результатах проверки для аудиторской фирмы. В противном случае аудиторская фирма даже выигрывает в финансовом отношении.

Повременная оплата наиболее широко распространена на рынке аудиторских услуг во всех странах. Эта форма устраняет недостатки аккордной. Появление непредвиденных обстоятельств лишь увеличивает трудоемкость и соответственно стоимость работ.

Повременная оплата базируется на оценке стоимости одного часа (дня) работы аудитора. Стоимость одного часа (дня) работы аудитора зависит и от его квалификации.

Сдельная оплата применяется, как правило, при восстановлении бухгалтерского учета. Расчет производится, исходя из определения стоимости одной операции, выполняемой аудитором, или стоимости одного показателя в отчетности.

При оплате по результатам аудитор отказывается от заранее определенной суммы за предоставленную услугу и определяет оплату в виде доли от сэкономленных для клиента финансовых ресурсов из-за ошибок и неточностей в ведении бухгалтерского учета, оформлении документации, при уплате налогов и т.п. Обычно устанавливается определенный процент от экономии. 
Комбинированная оплата - это различные комбинации из перечисленных выше форм и видов оплаты. Например, в договоре определяется общая стоимость услуги (аккорд) плюс определенный процент от экономики или резерв на непредвиденные обстоятельства и т.п.

Форма и содержание договоров оказания аудиторских услуг для различных аудируемых лиц могут иметь особенности, но, как правило, в договоре оказания аудиторских услуг указываются:

- цель аудита финансовой (бухгалтерской) отчетности;

- ответственность руководства аудируемого лица за подготовку и представление финансовой (бухгалтерской) отчетности;

- объем аудита, включая ссылки на законодательство Российской Федерации и федеральные правила (стандарты) аудиторской деятельности;

- аудиторское заключение и любые иные документы, которые предполагается подготовить по результатам аудита;

- информация о том, что в связи с применением в ходе аудита выборочных методов тестирования и другими свойственными аудиту ограничениями, наряду с ограничениями, присущими системам бухгалтерского учета и внутреннего контроля аудируемого лица, имеется неизбежный риск того, что некоторые, в том числе существенные, искажения финансовой (бухгалтерской) отчетности могут остаться необнаруженными;

- требование обеспечения свободного доступа ко всей бухгалтерской документации и другой информации, запрашиваемой в ходе проведения аудита;

- цена проведения аудита (либо способ ее определения), а также порядок признания услуги оказанной и порядок расчетов.

Таким образом, с точки зрения интересов аудитора и аудируемого лица, целесообразно заблаговременное подписание с предполагаемым аудируемым лицом договора оказания аудиторских услуг. 


\section{3. Оценка применимости допущения непрерывности деятельности в}

аудите ВЭД

Одним из основных аспектов аудита внешнеэкономической деятельности в последнее время становится оценка применимости допущения непрерывности деятельности, оцениваемое в соответствии с Федеральным правилом (стандартом) аудиторской деятельности № 11 «Применимость допущения непрерывности деятельности аудируемого лица».

Допущение непрерывности деятельности является основным принципом подготовки финансовой (бухгалтерской) отчетности. В соответствии с принципом допущения непрерывности деятельности обычно предполагается, что аудируемое лицо будет продолжать осуществлять свою финансовохозяйственную деятельность в течение 12 месяцев года, следующего за отчетным, и не имеет намерения или потребности в ликвидации, прекращении финансово-хозяйственной деятельности или обращении за защитой от кредиторов. Активы и обязательства учитываются на том основании, что аудируемое лицо сможет выполнить свои обязательства и реализовать свои активы в ходе своей деятельности.

Такие сомнения должны подтверждаться результатами выполнения аудиторских процедур и учитываться при составлении аудиторского заключения в соответствии с Федеральным правилом (стандартом) аудиторской деятельности № 6 «Аудиторское заключение».

Стоит отметить, что сомнение в применимости допущения непрерывности деятельности может возникнуть у аудитора при рассмотрении финансовой (бухгалтерской) отчетности или при выполнении иных аудиторских процедур на основании следующих признаков:

а) финансовые признаки:

- отрицательная величина чистых активов или невыполнение установленных требований в отношении чистых активов;

- привлеченные заемные средства, срок возврата которых приближается, при реальном отсутствии перспективы возврата или 
продления срока займа либо необоснованное использование краткосрочных займов для финансирования долгосрочных активов;

- изменение схемы оплаты товара (выполненных работ, оказанных услуг) поставщикам на условиях коммерческого кредита или рассрочки платежа по сравнению с расчетами по мере поставки товара (выполнения работ, оказания услуг);

- существенное отклонение значений основных коэффициентов, характеризующих финансовое положение аудируемого лица, от нормальных (обычных) значений;

- неспособность погашать кредиторскую задолженность в надлежащие сроки;

- неспособность обеспечить финансирование развития деятельности или осуществление других важных инвестиций;

- значительные убытки от основной деятельности;

- трудности с соблюдением условий договора о займе;

• задолженность по выплате или прекращение выплаты дивидендов;

- экономически нерациональные долговые обязательства;

- признаки банкротства, установленные законодательством Российской Федерации;

б) производственные признаки:

- увольнение основного управленческого персонала без должной его замены;

- потеря рынка сбыта, лицензии или основного поставщика;

- проблемы с трудовыми ресурсами или дефицит значимых средств производства;

- существенная зависимость от успешного выполнения конкретного проекта;2.4

- существенный объем продажи сырья и материалов, сравнимый с объемом выручки от реализации продукции (работ, услуг) или 
превышающий его;

в) прочие признаки:

- несоблюдение требований в отношении формирования уставного капитала аудируемого лица, установленных законодательством Российской Федерации;

- судебные иски против аудируемого лица, которые находятся в процессе рассмотрения и могут в случае успеха истца завершиться решением суда, не выполнимым для данного лица;

- внесение изменений в законодательство или изменение политической ситуации.

Кроме того, наличие одного или нескольких признаков не всегда является достаточным доказательством неприменимости допущения непрерывности деятельности при подготовке финансовой (бухгалтерской) отчетности аудируемого лица.

При выражении мнения о достоверности финансовой (бухгалтерской) отчетности аудируемого лица аудитор должен рассмотреть всю совокупность факторов, оказывающих и (или) способных оказать влияние на возможность этого лица продолжать деятельность и исполнять свои обязательства в течение как минимум 12 месяцев, следующих за отчетным периодом, и данные факторы должны быть раскрыты в финансовой (бухгалтерской) отчетности. Аудитор рассматривает надлежащий характер использования руководством аудируемого лица допущения о непрерывности деятельности даже в том случае, если требования к составлению финансовой (бухгалтерской) отчетности не предусматривают обязанности руководства аудируемого лица специально оценивать способность аудируемого лица продолжать свою деятельность непрерывно.

При этом аудитор не может предсказывать будущие события или условия, которые могут обусловить прекращение организацией еe непрерывной деятельности, поэтому отсутствие в аудиторском заключении каких-либо упоминаний о факторах неопределенности, касающихся непрерывности 
деятельности, не может рассматриваться как гарантия способности аудируемого лица продолжать свою деятельность непрерывно.

Совокупность показателей, характеризующих влияние внешнеэкономической деятельности на финансовое состояние организации, определяется задачами, стоящими перед аудитором при проведении анализа финансово-хозяйственной деятельности клиента. Система показателей финансового анализа внешнеэкономической деятельности должна быть такова, чтобы по результатам этого анализа аудитор мог получить максимально достоверную информацию, позволяющую ему обосновать свой вывод о возможности дальнейшего функционирования проверяемой организации.

Доказательства, подтверждающие сомнения в применимости допущения непрерывности деятельности организации, могут быть получены аудитором в результате выполнения определенных аудиторских процедур, среди которых можно выделить:

- обсуждение с управленческим персоналом прогнозов прибыли и движения денежных потоков,

- ознакомление с протоколами общего собрания акционеров, заседания совета директоров, исполнительного органа,

- изучение условий договоров займов и кредитов.

Анализ полученной информации должен быть направлен на выявление фактов, свидетельствующих о трудностях в финансировании деятельности клиента. В этих же целях изучается положение с выполнением заказов и анализируются причины их невыполнения.

На возможность проверяемого экономического субъекта продолжать дальнейшую деятельность и исполнять свои обязательства способны повлиять события, происшедшие после отчетной даты, которые в силу этого также должны быть проанализированы аудитором.

Прояснить сложившееся в организации положение могут письменные разъяснения руководства относительно того, какие меры планируется предпринять для улучшения финансового состояния экономического субъекта. В 
качестве таких мер могут быть запланированы распродажа имущества, получение заемных денежных средств, сокращение расходов, реструктуризация задолженности и др.

Все запланированные действия должны быть тщательно проанализированы аудитором:

- реально ли их осуществление,

- могут ли они принести ожидаемый результат.

C учетом всей совокупной информации аудитор делает вывод о возможности применения к проверяемому экономическому субъекту допущения о непрерывности деятельности организации. Поскольку вывод крайне важен для пользователей бухгалтерской отчетности, но по отдельным разрозненным фактам сделать объективные выводы невозможно, аудитору следует осуществить финансовый анализ деятельности организации. Задача финансового анализа в аудите заключается в том, чтобы с его помощью подтвердить финансовую устойчивость организации или обнаружить признаки финансовой нестабильности.

Если в деятельности клиента значительный удельный вес занимает внешнеэкономическая деятельность, то именно она может оказывать существенное влияние на его финансовое положение. Поэтому система показателей финансового анализа внешнеэкономической деятельности должна быть направлена на определение характера этого влияния, установление тех явлений, которые отрицательно сказываются на финансовом состоянии организации, и выявление неиспользованных возможностей для укрепления ее финансовой устойчивости.

В соответствии с существующей практикой критерий эффективности внешнеэкономической деятельности основан на получении валового дохода от еe реализации. По своему экономическому содержанию валовой доход от реализации импортного товара аналогичен валовому доходу торговли в других секторах экономики и показателю валовой (маржинальной) прибыли, используемому в западном бухгалтерском анализе. По существу он 
представляет собой разность цен покупки и продажи импортного товара, поэтому основной задачей анализа валового дохода следует считать анализ соотношения покупной и продажной цен на импортный товар.

Анализ валового дохода от импортной сделки предполагает анализ товарного ассортимента контракта. Однако иногда анализ каждой позиции товарного ассортимента бывает очень трудоемок из-за большого количества наименований импортируемых товаров. В таких случаях можно рекомендовать укрупнять объекты анализа для снижения его трудоемкости и повышения достоверности результатов. Это означает, что если объектом поставки по контракту является однородный товар с одной ассортиментной позицией, то можно анализировать соотношение цен покупки и продажи по единице товара. Если объектом поставки является однородный или разнородный товар со множеством ассортиментных позиций, то целесообразно провести сопоставление цен покупки и продажи по единице товара каждой ассортиментной позиции и по контракту в целом. Принципиальным является то, что при анализе соотношения цен покупки и продажи единицы товара продажная цена берется как средняя из - за того, что продажа всей партии товара по одной цене является исключением. При анализе соотношения цен покупки и продажи в целом по партии товара или всему контракту необходимость расчета средней цены реализации отпадает.

Динамика валового дохода от продажи импортного товара не позволяет сделать однозначный вывод об эффективности импортных закупок из-за влияния фактора изменения курса национальной валюты. Существует и другая проблема оценки эффективности исполнения импортного контракта при сопоставлении цен покупки и продажи путем исчисления абсолютного показателя валового дохода. Это отсутствие какой-либо базы сравнения, кроме величин валового дохода от реализации других позиций товарного ассортимента. Однако все они имеют разные контрактные цены и количество, и простое сопоставление сумм валового дохода не дает представления о величине оборотного капитала, участвующего в образовании валового дохода от 
реализации импортного товара.

Поэтому для повышения достоверности результатов анализа на стадии сравнения величин валового дохода от реализации разных наименований импортного товара требуется использование широко распространенного для целей анализа метода бухгалтерской нормы рентабельности.

Содержание данного метода состоит в определении относительного показателя - финансового коэффициента рентабельности продаж импортного товара, коэффициент доходности или коэффициент бухгалтерской рентабельности. В числителе коэффициента рентабельности находится показатель бухгалтерской прибыли. Применительно к анализу эффективности исполнения импортных контрактов следует применять показатель валового дохода (БД) от реализации импортного товара. В знаменателе находится оборотный капитал (ОК). В частном случае он может совпадать с внешнеторговой себестоимостью импортного товара (BC).

Применительно к анализу эффективности импортных сделок аналитическая формула коэффициента доходности имеет следующий вид:

$\mathrm{K}_{\text {д }}=(\mathrm{TO}-\mathrm{OK}): \mathrm{OK}=$ ВД : OK,

где $\mathrm{K}_{\text {д }}$ - коэффициент доходности;

ВД - валовой доход;

ТО - выручка от продаж импортного товара по контракту (в рублях, без НДС), или товарооборот в продажных ценах без НДС;

ОК — оборотный капитал, авансированный в исполнение сделки.

Стоит отметить, что коэффициент доходности называется также коэффициентом отдачи оборотного капитала.

Для оценки эффективности импортных операций помимо коэффициента доходности рассчитываются также коэффициенты прибыльности и оборачиваемости активов. Коэффициентом прибыльности принято называть отношение валового дохода или прибыли к товарообороту. Его аналитическая формула имеет следующий вид:

$$
\mathrm{K}_{\Pi}=(\mathrm{TO}-\mathrm{OK}): \text { ТО = ВД : ТО, }
$$


где $K_{п}$ — коэффициент прибыльности;

ВД - валовой доход;

ТО - выручка от продаж импортного товара по контракту (в рублях, без НДС), или товарооборот в продажных ценах без НДС;

ОК — оборотный капитал, авансированный в исполнение сделки.

Экономическое содержание данных коэффициентов состоит в том, что они указывают на процентное отношение маржинальной прибыли от исполнения проекта к оборотному капиталу. Таким образом, коэффициенты рентабельности указывают на сумму валового дохода от продаж импортного товара, приходящегося на единицу оборотного капитала.

Коэффициент бухгалтерской рентабельности указывает на сумму прибыли, приходящейся на единицу авансированного в исполнение контракта оборотного капитала, т.е. инвестиций, а коэффициент прибыльности - на сумму маржинальной прибыли, приходящейся на единицу выручки от реализации импортного товара.

Коэффициенты доходности и прибыльности взаимосвязаны. Эту взаимосвязь выражает уравнение

Кд ${ }^{=} K_{п} \cdot K_{\mathrm{a}}$, где $\mathrm{K}_{\mathrm{a}}$ - коэффициент оборачиваемости активов (ТО : ОК).

Поскольку значения относительных коэффициентов не зависят от количественного фактора, то расчет коэффициентов рентабельности можно производить как для партии импортного товара, так и в целом по контракту. Расчет следует вести в национальной и иностранной валюте.

Расчет коэффициентов рентабельности партий импортного товара обеспечит сопоставимость результатов расчета со значениями коэффициентов оборачиваемости импортного товара.

В условиях стабильного курса национальной валюты фирма-импортер может продавать различные по количеству единиц партии импортного товара с одинаковой доходностью. Однако в условиях падения курса национальной валюты импортер может минимизировать потери от неблагоприятного изменения курса иностранной валюты и максимизировать прибыль от сделки путем формирования 
портфеля заказов на импортный товар еще до его ввоза на таможенную территорию России. Вместе с тем в условиях невысокого уровня развития рыночных отношений это бывает затруднительно. Кроме того, специфика деятельности некоторых внешнеторговых предприятий вообще исключает такую возможность. Это относится, например, к импортерам, реализующим импортный товар по схеме «таможенная очистка - оптовый склад - розничные магазины». В этих случаях при заключении контракта необходимо ориентироваться на результаты предварительного анализа эффективности намечаемой сделки, основанного на оценке размера среднедневных продаж импортного товара определенного ассортимента или ассортиментной позиции [17].

Для повышения эффективности продаж больших партий импортного товара необходимо разработать шкалу скидок с текущей продажной цены импортного товара в зависимости от размера продажи. В случаях когда реализация товара все равно идет медленными темпами относительно ранее сделанного прогноза, необходимо принимать решение о снижении уровня средней продажной цены.

При планировании спроса и уровня продажной цены на импортный товар следует учитывать степень его рыночной новизны и диапазон приемлемых рыночных цен. Применение метода бухгалтерской нормы рентабельности упрощает сопоставление цен покупки и продажи импортного товара и позволяет производить не только оперативный и последующий анализ эффективности его реализации, но и прогнозировать сбыт импортного товара путем расчета критических значений финансовых коэффициентов и обменного курса национальной валюты.

Расчет финансовых коэффициентов не решает полностью проблему сравнимости контрактов, так как не учитывает разность в сроках их исполнения. Между тем выбор объекта анализа подразумевает построение методики, позволяющей сравнивать контракты независимо от их натуральновещественной формы, условий поставки и реализации. В ходе анализа необходимо использовать метод приведения показателя количества партии 
товара к уровню одной из них и обеспечить более достоверный уровень сравнимости финансовых коэффициентов по продажам импортного товара различных партий.

Ограниченность свободного оборотного капитала для финансирования импортной сделки предопределяет необходимость привлечения фирмойимпортером заемных денежных средств для оплаты импортного контракта. Ввиду низкой капитализации отечественных субъектов внешней торговли наиболее распространенными источниками финансирования импортных сделок на внутреннем, российском рынке выступает либо выручка от реализации импортного товара, либо банковский кредит.

Использование выручки от реализации импортного товара и коммерческого кредита в качестве источника финансирования импортной сделки предполагает наличие доверительных отношений с иностранным поставщиком, предоставляющим коммерческий кредит отечественному покупателю. Кроме того, в контрактную цену импортного товара закладывается стоимость данного кредита исходя из цены денег на внутреннем рынке поставщика.

В настоящее время получение банковского кредита сопровождается сложной процедурой оформления, включающей представление бизнес-плана и какого-либо материального обеспечения кредита. Кроме того, сдерживающим фактором является высокая цена денег вообще на внутреннем российском рынке относительно мирового уровня. Поэтому цена оборотного капитала контракта тоже является существенным ограничением для импортера [17].

Наряду с дивидендами акционерам фирмы-импортера, другими выплатами за счет прибыли предприятием акционерам и сотрудникам плата за кредит выступает составной частью цены оборотного капитала фирмы-импортера. Для принятия решения о целесообразности проведения той или иной импортной сделки, а также для определения ее результативной эффективности необходимо сопоставить доходность импортных сделок с ценой используемого оборотного капитала: собственного и заемного. 
Целью определения цены заемного капитала является дальнейшее сопоставление ее либо с валовым доходом от реализации импортного товара, либо с коэффициентами рентабельности исполнения импортного контракта. Основная идея этого метода состоит в том, чтобы не допустить расходования средств более дорогих по условиям их получения, чем получаемый эффект от вовлечения их в деловой оборот в виде финансовых норм их отдачи. Предельным является вариант вложения средств, при котором цена капитала и норма финансовой отдачи вложенных средств оказываются равными. Под нормами финансовой отдачи импортной сделки надо понимать коэффициенты рентабельности (Кд), под ценой капитала - ставку привлечения банковского кредита либо других заемных или собственных средств для авансирования импортного контракта, или его части, под вложенными средствами и капиталом- среднюю сумму авансированного в исполнение сделки оборотного капитала.

Помимо заемных средств для внешнеэкономической деятельности могут привлекаться и собственные средства. Они также имеют свою специфическую цену — в виде дивидендов акционерам или выплат из прибыли участникам. Расчет цены собственного капитала для отдельной внешнеэкономической сделки производится на основании уровня цены собственного капитала предприятия и аналогичен расчету платы за пользование кредитом для финансирования внешнеэкономической сделки.

Для целей анализа внешнеэкономических контрактов важно определить не только уровень цены оборотного капитала (в процентах), но и рассчитать сумму платы за пользование капиталом на одно изделие. Такая необходимость объясняется существованием еще одного ограничения импортной сделки критической продажной цены.

Это цена, при которой валовой доход от продажи товара равен нулю.

Подобная ситуация может быть названа точкой безубыточности импортного контракта. Такое определение точки безубыточности правомерно при допущении о нерелевантности постоянных расходов фирмы-импортера 
относительно финансовых результатов исполнения контракта и соответствует концепции маржинального учета, согласно которой постоянные затраты не участвуют в анализе отдельной сделки, а относятся непосредственно на финансовые результаты деятельности всего предприятия.

Согласно концепции маржинального учета не представляется возможным абсолютно достоверно распределить постоянные затраты между учетными периодами и видами продукции. Кроме того, для целей оперативного анализа менеджеру особенно важно следить за уровнем валового дохода предприятия и переменных затрат, так как уровень постоянных затрат обязательно сокращается при росте товарооборота.

Определение критической продажной цены и расчет точки безубыточности импортного контракта являются предметом перспективного анализа импортной сделки. Его результаты используются импортером в дальнейшем при оперативном анализе исполнения сделки с учетом фактических обстоятельств ее протекания. В любом случае результаты первого этапа анализа являются основанием для принятия управленческих решений о заключении сделки с иностранным поставщиком, а также о тактике импортера при установлении продажной цены импортного товара на внутреннем рынке.

Аудитору необходимо использовать результаты такого анализа в процессе обсуждения с клиентом качества управления безубыточностью импортных сделок.

Стоит отметить, что критическая точка исполнения импортного контракта удовлетворяет условию:

$$
\begin{aligned}
& \mathrm{K}_{\mathrm{a}}=1, \\
& \mathrm{~K}_{\text {п }}=0, \\
& \mathrm{~K}_{\text {д }}=0,
\end{aligned}
$$

где $\mathrm{K}_{\mathrm{a}}$ - коэффициент оборачиваемости активов;

$\mathrm{K}_{\text {п }}$ - коэффициент прибыльности;

$\mathrm{K}_{\text {д }}$ - коэффициент доходности. 
Для проведения дальнейшего исследования необходимо использовать основные параметры импортного контракта:

$k$ - текущий обменный курс валюты контракта;

$\mathrm{C}_{\S}$ - внешнеторговая себестоимость единицы импортного товара в валюте контракта;

кп - курс пересчета внешнеторговой себестоимости импортного товара в рубли (в соответствии с российскими стандартами бухгалтерского учета);

$\mathrm{Cp}$ - внешнеторговая себестоимость импортного товара в рублях;

Ц - текущая продажная цена в рублях (с учетом числа продаж импортного товара по контракту).

Внешнеторговую себестоимость единицы импортного товара (в руб.) представим следующим образом:

$\mathrm{C}_{\mathrm{P}}=\mathrm{C}_{\S} \mathrm{K} \Pi$.

Тогда критическое значение коэффициента оборачиваемости активов по исполнению импортного контракта будет соответствовать условию:

Коб

где Коб активов.

Из приведенного уравнения следует, что цена является критической продажной ценой. Тогда справедливо следующее:

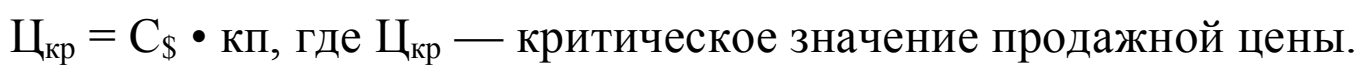

Поскольку показатель кп является константой, продажа товара по критической продажной цене обеспечивает лишь рублевую окупаемость затрат в исполнении сделки без учета платы за кредит [17].

Чтобы принять во внимание цену заемных средств необходимо рассчитать критическую продажную цену в соответствии с уравнением

$Ц_{\text {кр }}^{\prime}=\left(\mathrm{C}_{\$} \cdot\right.$ кп $)+S$,

где Ц'кр - критическое значение продажной цены с учетом платы за кредит; 
$S$ - плата за кредит (сумма начисленных процентов) в расчете на одно импортное изделие.

Включая плату за кредит в критическую продажную цену, можно обеспечить не только простую окупаемость рублевых вложений в импортную сделку, но и окупаемость затрат оборотного капитала.

Для определения критической продажной цены, обеспечивающей валютную окупаемость затрат оборотного капитала в импортные операции, необходимо учесть в расчете критической продажной цены текущий обменный курс валюты контракта. Так как кредит на оплату импортного контракта может быть выдан в рублях, то валютная окупаемость затрат капитала необходима в части оплаты контрактной цены импортного товара, тогда как плата за кредит не зависит непосредственно от изменений текущего обменного курса. Формула расчета критической продажной цены в рублях с учетом платы за кредит и изменения курса валюты контракта будет иметь следующий вид [17]:

$Ц^{\prime \prime р ~}=\left(\mathrm{C}_{\$} \bullet \kappa\right)+S$,

где Ц" кр — критическое значение продажной цены с учетом платы за кредит и текущего обменного курса (к);

$S$ - плата за кредит (сумма начисленных процентов) в расчете на одно импортное изделие.

Поскольку показатель ㄸ не является константой, продажа товара по критической продажной цене обеспечивает и рублевую, и валютную окупаемость затрат в исполнении сделки с учетом платы за кредит.

Таким образом, в зависимости от целей анализа и конкретных условий проведения импортной сделки для определения критической продажной цены в рублях, обеспечивающей окупаемость затрат оборотного капитала в сделке по импорту, можно использовать одну из рассмотренных формул.

С их помощью определим точку безубыточности продаж партии импортного товара по контракту с учетом платы за кредит на единицу 
импортного товара, но без учета текущего обменного курса. Она будет соответствовать следующему объему товарооборота:

$$
\mathrm{Q}_{\mathrm{P}}=\mathrm{q} \cdot\left[\left(\mathrm{C}_{\$} \cdot \kappa \Pi\right)+\mathrm{S}\right]=\mathrm{q} \cdot Ц_{\text {кр }}^{\prime},
$$

где $\mathrm{Q}_{\mathrm{p}}$ - критическое значение товарооборота в продажных (рублевых) ценах для отдельной продажи импортного товара;

q — количество товара, проданного по текущей продажной цене (Ц);

Ц'кр — критическое значение продажной цены с учетом платы за кредит;

$\mathrm{S}$ - плата за кредит (сумма начисленных процентов) в расчете на одно импортное изделие;

кп - курс пересчета внешнеторговой себестоимости импортного товара в рубли.

Точка безубыточности отдельной продажи импортного товара из партии с учетом платы за кредит на единицу импортного товара $(S)$ и текущего обменного курса (к) будет соответствовать следующему объему товарооборота:

$$
\mathrm{Q}_{\mathrm{P}}^{\prime}=\mathrm{q} \cdot \Pi \cdot\left[\left(\mathrm{C}_{\$} \cdot \kappa\right)+\mathrm{S}\right]=\mathrm{q} \cdot \Pi \cdot Ц^{\prime \prime}{ }_{\mathrm{кр}},
$$

где $\mathrm{Q}_{\mathrm{p}}$ — критическое значение товарооборота в продажных (рублевых) ценах для импортного товара, проданного по текущей продажной цене Ц; q — количество товара в отдельной продаже;

п — число продаж партий импортного товара;

к — текущий обменный курс валюты контракта;

Ц"кр критическое значение продажной цены с учетом платы за кредит и текущего обменного курса к;

$\mathrm{S}$ - плата за кредит (сумма начисленных процентов) в расчете на одно импортное изделие.

Вычисление критического размера товарооборота по контракту достаточно трудоемко, поэтому ее можно упростить, используя среднюю критическую цену реализации партии импортного товара: 
$Q_{n a p m}^{c p}=\mathrm{q} \cdot \Pi \cdot Ц_{\mathrm{cp}}$,

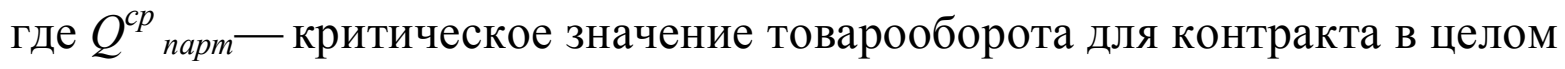

с учетом средней критической цены реализации партии импортного товара;

$q$ - количество импортного товара в партии;

$n$ - число продаж партий импортного товара;

$Ц_{\text {ср }}$ - средняя цена реализации партии импортного товара с учетом платы за кредит и изменения текущего обменного курса.

Таким образом, расчет платы за банковский кредит на единицу импортного товара и учет ее значения при определении критического значения товарооборота продаж отдельных партий импортного товара позволяет определить эффективность исполнения импортного контракта с точки зрения соотношения цены оборотного капитала импортного контракта и нормы его финансовой отдачи - коэффициентов рентабельности исполнения импортного контракта в агрегированном виде.

Несмотря на то, что согласно правилам отражения в бухгалтерском учете валютных операций стоимость импортного товара на складе не переоценивается с учетом изменения текущего обменного курса иностранной валюты, для целей анализа на безубыточность необходимо определять критическую цену реализации импортного товара исходя из уровня текущего обменного курса и внешнеторговой себестоимости импортного товара в валюте контракта $\left(\mathrm{C}_{\$}\right.$ к).

Для целей анализа важно также определять точку безубыточности продаж каждой партии товара, учитывая, что финансовый результат от реализации любой единицы товара является источником валового финансового результата от исполнения импортного контракта. Это означает расчет критического значения товарооборота для отдельной продажи импортного товара. Если такой расчет составить для каждой продажи импортного товара, тогда сумма валового финансового результата от продажи всего товара данного наименования будет соответствовать сумме частных финансовых результатов от реализации партий импортного товара с учетом 
ошибки от округления и расчета средних значений основных параметров импортного контракта.

Рассчитаем критические значения основных параметров импортного контракта с помощью таблицы 7 [17].

Таблица 7

Расчет критических значений продажной цены и обменного курса по продажам импортного товара

\begin{tabular}{|c|c|c|c|c|c|c|}
\hline $\begin{array}{c}\text { № } \\
\text { ПI/II }\end{array}$ & $\begin{array}{c}\text { Дата } \\
\text { продажи }\end{array}$ & $\begin{array}{c}\text { Текущий } \\
\text { обменный } \\
\text { курс ЦБРФ, } \\
\text { руб. }\end{array}$ & $\begin{array}{c}\text { Критическая } \\
\text { цена } \\
\text { продажи, руб. }\end{array}$ & $\begin{array}{c}\text { Критическая } \\
\text { цена реали- } \\
\text { зации с учетом } \\
\text { платы } \\
\text { за кредит, руб. }\end{array}$ & $\begin{array}{c}\text { Критическая цена } \\
\text { реализации с учетом } \\
\text { платы за кредит и } \\
\text { текущего обменного } \\
\text { курса, руб. }\end{array}$ & $\begin{array}{c}\text { Фактиче- } \\
\text { ская цена } \\
\text { реали- } \\
\text { зации, руб }\end{array}$ \\
\hline 1 & 2 & 3 & 4 & 5 & 6 & 7 \\
\hline 1 & $08 / 02$ & 33,47 & 167,35 & 200 & 200 & 237,50 \\
\hline 2 & $19 / 03$ & 34,04 & 170,20 & 200 & 204 & 237,50 \\
\hline 3 & $25 / 03$ & 34,19 & 170,95 & 200 & 205 & 230,00 \\
\hline 4 & $31 / 03$ & 34,19 & 170,95 & 200 & 205 & 196,24 \\
\hline 5 & $01 / 04$ & 34,29 & 171,45 & 200 & 205 & 197,00 \\
\hline 6 & 02/04 & 34,29 & 171,45 & 200 & 205 & 196,24 \\
\hline 7 & $05 / 04$ & 34,29 & 171,45 & 200 & 205 & 190,00 \\
\hline 8 & $18 / 06$ & 36,58 & 182,90 & 200 & 220 & 197,00 \\
\hline
\end{tabular}

Из данных таблицы 7 следует, что условие безубыточности продаж партии импортного товара выполнялось до 25 марта включительно, так как критическая цена реализации импортного товара с учетом платы за кредит и текущего обменного курса (гр. 6 табл. 7) была ниже фактической цены реализации импортного товара (гр. 7). Остальные продажи партии товара были убыточными. Например, в период после 5 апреля фактическая цена реализации товара составила 190 руб., тогда как для возмещения внешнеторговой себестоимости импортного изделия с учетом процентов по кредиту продажная цена должна была составить 200 руб. (стр. 7 гр. 5), а для безубыточной реализации требовалось продать товар по цене 205 руб. Это не соответствовало текущим рыночным ценам и, следовательно, было невозможно. 
Следует отметить, что точка безубыточности продаж импортного товара была достигнута через полтора месяца после первой продажи поступившего товар, так что импортер имел достаточный запас времени для реализации всего товара без убытка.

Таким образом, падение доходности продаж последних партий товара по сравнению с началом продаж по контракту естественно в связи с тем, что оно происходит к концу периода хранения товара на складе. Поэтому при оценке степени влияния на общую доходность исполнения контракта последних продаж целесообразно сравнить объем убыточно продаваемых партий товара с общим объемом поставки. Рассмотрим структуру продаж импортного товара с помощью данных таблицы 8.

Таблица 8

\section{Структура продаж импортного товара}

\begin{tabular}{|c|c|c|}
\hline $\begin{array}{c}\text { Дата } \\
\text { продажи }\end{array}$ & $\begin{array}{c}\text { Объем продаж в } \\
\text { партии, шт. }\end{array}$ & $\begin{array}{c}\text { Удельный вес партии в общем объеме } \\
\text { поставки, \% }\end{array}$ \\
\hline $08 / 02$ & 40 & 0,1 \\
\hline $19 / 03$ & 5000 & 18,0 \\
\hline $19 / 03$ & 200 & 0,7 \\
\hline $19 / 03$ & 50 & 0,2 \\
\hline $25 / 03$ & 340 & 1,2 \\
\hline $31 / 03$ & 5117 & 18,4 \\
\hline $01 / 04$ & 200 & 0,7 \\
\hline $02 / 04$ & 1320 & 4,8 \\
\hline $05 / 04$ & 15000 & 54,1 \\
\hline $18 / 06$ & 200 & 0,7 \\
\hline $18 / 06$ & 254 & 0,9 \\
\hline Итого & 27721 & 100,0 \\
\hline & & \\
\hline
\end{tabular}

Данные, приведенные в таблицах 7 и 8, показывают, что, начиная с 31 марта продажи были убыточны, а значит, с убытком продано 79,7\% общего объема партии. Поэтому, несмотря на то, что имеется валовой доход от продажи, исполнение сделки оказалось неэффективным. Важное значение в отрицательном результате исполнения сделки имеет то, что размер платы за кредит превысил суммы дохода от реализации импортного товара начиная с 31 марта.

Далее согласно методике расчета определим критические значения товарооборота для партии импортных товаров. Расчет произведем с помощью таблицы 9. 
Расчет критических значений товарооборота для продаж партии импортного товара

\begin{tabular}{|c|c|c|c|c|c|c|}
\hline № & Дата & $\begin{array}{c}\text { Кол- } \\
\text { во, ед. }\end{array}$ & $\begin{array}{c}\text { Критическая } \\
\text { цена с } \\
\text { учетом } \\
\text { платы 3a } \\
\text { кредит, руб. }\end{array}$ & $\begin{array}{c}\text { Критическая } \\
\text { цена с учетом } \\
\text { платы за кре- } \\
\text { дит и теку- } \\
\text { щего курса, } \\
\text { руб. }\end{array}$ & $\begin{array}{c}\text { Критический } \\
\text { товарооборот }\end{array}$ & $\begin{array}{c}\text { Фактический } \\
\text { товарооборот }\end{array}$ \\
\hline $\mathbf{1}$ & $\mathbf{2}$ & $\mathbf{3}$ & $\mathbf{4}$ & $\mathbf{5}$ & $\mathbf{6}$ & 7 \\
\hline 1 & $08 / 02$ & 40 & 200 & 200 & 8000 & 9500 \\
\hline 2 & $19 / 03$ & 5250 & 200 & 204 & 1071000 & 1246875 \\
\hline 3 & $25 / 03$ & 340 & 200 & 205 & 69700 & 78200 \\
\hline 4 & $31 / 03$ & 5117 & 200 & 205 & 1048985 & 1004160 \\
\hline 5 & $01 / 04$ & 200 & 200 & 205 & 41000 & 39400 \\
\hline 6 & $02 / 04$ & 1320 & 200 & 205 & 270600 & 259037 \\
\hline 7 & $05 / 04$ & 15000 & 200 & 205 & 3075000 & 2850000 \\
\hline 8 & $18 / 06$ & 454 & 200 & 220 & 99880 & 89438 \\
\hline \multicolumn{2}{|c|}{ Сумма } & 27721 & 5544200 & $X$ & 5684165 & 5576610 \\
\hline
\end{tabular}

В гр. 6 таблицы 9 приведены критические значения товарооборота для отдельной продажи импортного товара. Итог гр. 6 представляет собой критическое значение товарооборота с учетом платы за кредит и текущего обменного курса и составляет 5684165 руб.

Фактическое значение товарооборота составило 5576610 руб. (итог гр. 7), то есть валовой убыток от исполнения импортного контракта с учетом платы за банковский кредит и текущего обменного курса составляет 107555 руб.

В различных ситуациях, складывающихся на рынке импортных товаров, бывает необходимо принять решение об изменении уровня продажных цен товаров для стимулирования спроса или минимизации убытков от медленной реализации складских запасов товаров. Основанием для принятия таких решений всегда являются результаты анализа, аналогичного рассмотренного.

Приведенные в данном примере методы экономического анализа можно использовать при проведении обязательного аудита и при проведении аудита внешнеэкономической деятельности в целом, в частности в процессе оценки применимости принципа непрерывности деятельности для аудируемой организации. 


\section{4. Планирование и программа аудита ВЭД}

При планировании аудита вместе с соблюдением общих принципов должны соблюдаться и его частные принципы, к которым относятся: комплексность, непрерывность и оптимальность планирования.

Планирование аудита заключается в определении его стратегии и тактики, выборе процедур и методов, позволяющих наиболее эффективно достичь поставленной цели,- подтверждения достоверности бухгалтерской отчетности.

Аудитор должен построить своеобразную целевую функцию, учитывая число и уровень квалификации требуемых специалистов, устанавливая сроки выполнения работ по конкретному аудиту и увязывая их с другими проектами, осуществляемыми фирмой, а также определяя методы и способы получения достаточных аудиторских доказательств, базирующихся на принимаемых аудитором допущениях.

Процесс планирования подразделяется на взаимосвязанные этапы, которые условно можно разделить на три стадии:

1) стадию изучения;

2) стадию оценки;

3) механическую стадию.

На стадии изучения аудитор получает базовую информацию об организации, осуществляющей внешнеэкономическую деятельность, в том числе данные о специфике ее деятельности, системах бухгалтерского учета и внутреннего контроля, программном обеспечении, среде компьютерной обработки данных (КОД), критических (значимых) областях аудита.

При определении областей, значимых для аудита, целесообразно использовать аналитические процедуры.

Большое место отводится результатам исследования системы внутреннего контроля. Ее эффективность, степень автоматизации обработки учетной информации являются факторами, влияющими на объем и характер 
планируемых аудиторских процедур.

Стадия оценки предполагает действия по определению приемлемых уровней существенности и аудиторского риска, позволяющих считать бухгалтерскую отчетность достоверной. При этом уровень существенности рассчитывается в соответствии с принятой аудиторской организацией методикой. Определяя уровень аудиторского риска, аудитор должен дать оценку трем его составляющим - внутрихозяйственному риску, риску средств контроля и риску необнаружения.

Значения этих показателей аудитор может рассчитать только на базе предварительных данных, полученных в ходе изучения бизнеса клиента, его систем бухгалтерского учета и внутреннего контроля, среды КОД.

После этого аудитор может перейти к механической стадии, в ходе которой формируются общий план и программа аудита, решаются вопросы организации работы аудиторов, распределяются обязанности по проверке и т. д.

В приложении 4 представлена типовая схема этапа планирования аудита.

Таким образом, в соответствии с приложением 4 порядок проведения аудиторской проверки организаций, осуществляющих внешнеэкономическую деятельность можно представить следующим образом:

1.Официальное предложение организации о проведении аудиторской проверки и/или оказанию сопутствующих аудиторских услуг.

2. Предварительное планирование аудита аудиторской фирмой:

а) Ознакомление с финансово-хозяйственной деятельностью организации;

б) Оценка возможности проведения аудита;

в) Формирование штата для проведения аудита.

3. Письмо-обязательство аудиторской фирмы о согласии на проведение аудита с изложением обязательных условий аудита и дополнительных сведений об особенностях проведения аудита по своему усмотрению или в соответствии с пожеланиями организации. 
4. Письменное согласие исполнительного органа организации на условия аудита, предложенные аудиторской фирмой (как правило, на втором экземпляре письма-обязательства, возвращаемого аудиторской фирме).

5. Заключение договора о проведении аудита.

6. Планирование аудита:

а) Оценка эффективности системы внутреннего контроля, действующей в организации;

б) Установление приемлемых уровней существенности и аудиторского риска;

в) Разработка общего плана и программы аудита.

7. Сбор аудиторских доказательств и оценка влияния выявленных обстоятельств на достоверность бухгалтерской отчетности.

7.1. В случае выявления обстоятельств, требующих корректировки плана или программы аудита, изменения уровня существенности, внесения необходимых изменений в план (программу) аудита и сбор дополнительных аудиторских доказательств.

8. Подготовка аудиторского отчета - письменной информации аудитора руководству проверяемой организации по результатам проведения аудита.

8.1. Предложение организации устранить выявленные нарушения, произвести необходимые исправительные проводки и в установленных случаях внести изменения в бухгалтерскую отчетность.

8.2. Оценка исправлений, произведенных организацией.

9. Подготовка аудиторского заключения с учетом выявленных обстоятельств и результатов анализа внесенных исправлений.

10. Выдача аудиторского заключения.

10.1. Оценка произошедших после выдачи заключения событий, ставших известными аудитору 
10.2. Обсуждение возникших проблем с руководством организации.

10.3. Осуществление действий, предусмотренных стандартами аудиторской деятельности.

С целью планирования аудиторская фирма должна ознакомиться с финансово-хозяйственной деятельностью организации и иметь информацию о внешних и внутренних факторах, влияющих на ее деятельность, а также ознакомиться с дополнительной информацией:

1. Внешние факторы:

1.1. Оценка экономической ситуации в городе и регионе:

- наличие крупных промышленных предприятий и их отраслевая специализация;

- уровень деловой активности в городе и регионе;

- наличие крупных недоимщиков по бюджету в городе и регионе;

- наличие крупных экспортеров и импортеров;

- степень участия предприятий города и региона в капитале организации.

1.2. Особенности финансового рынка по месту нахождения организации:

- наличие местных, в том числе крупных, банков;

- наличие филиалов столичных, в том числе крупных, банков;

- наличие филиалов других, в том числе крупных, банков;

- отраслевая специализация города и региона и наличие соответствующих специализированных банков;

- финансовая и деловая активность других банков;

- наличие финансового рынка в городе и регионе, его организация (биржи, иные профессиональные участники рынка ценных бумаг и т.п.), структура активных участников финансового рынка, завершенность «раздела ф финансового рынка 
(сформированность, заполненность и стабильность рыночных ниш);

- финансовая активность органов власти города и региона (наличие долга муниципального органа власти или органа власти субъекта федерации в виде ценных бумаг), участие органов региональной и муниципальной власти в организациях;

- финансовая активность организаций и предприятий города и региона (эмиссионная деятельность, участие в банковских и финансовых структурах и т.д.).

2. Внутренние факторы:

- структура собственников организации (соотношение физических и юридических лиц, крупных и мелких участников и т.д.);

- существенные изменения в организационной форме или составе участников, причины и цели таких изменений;

- структура поставщиков и покупателей организации по экспортным и импортным товарам (соотношение физических и юридических лиц, крупных, средних и мелких организаций, их отраслевая принадлежность и т.д.);

- существенные изменения в структуре поставщиков и покупателей организации по экспортным и импортным операциям, причины таких изменений и оценка их последствий;

- финансовая и деловая активность крупных собственников и клиентов организации;

- уровень номинального и фактического участия собственников организации в управлении ею (их доли в уставном капитале, представительство в совете директоров, компетенция совета директоров и т.д.);

- основные источники финансирования организации.

По результатам анализа полученной информации в рабочей документации должна быть отражена следующая информация:

- организационно - управленческая структура организации и ее 
документационное обеспечение (наличие положений, приказов, должностных инструкций и т.п.);

- виды лицензий на совершение операций;

- структура капитала, обращаемость и курс акций, их динамика;

- технологические особенности деятельности организации (используемые автоматизированные системы, средства коммуникации, применение нетрадиционных финансовых технологий и т.п.);

- уровень рентабельности и его динамика;

- основные поставщики и покупатели по внешнеэкономическим операциям;

- порядок распределения прибыли, остающейся в распоряжении организации;

- существование дочерних и зависимых организаций;

- организация системы внутреннего контроля;

- принципы формирования оплаты труда персонала.

В соответствии с положениями Стандарта источниками получения информации об организации применительно к аудиту должны являться:

- учредительные документы и документы о регистрации организации;

- протоколы собрания участников (акционеров) и заседаний совета директоров и других управляющих органов;

- документы, регламентирующие учетную политику организации;

- бухгалтерская и статистическая отчетность;

- документы планирования деятельности организации;

-контракты и прочие юридические основания договорных отношений проверяемой организации;

- внутренние отчеты аудиторов, консультантов;

- внутрифирменные инструкции;

- материалы налоговых проверок;

- материалы судебных исков; 
- документы, регламентирующие организационную структуру организации, в том числе касающиеся ее филиалов;

- сведения, полученные из бесед с руководством и исполнительным персоналом;

- информация, полученная при осмотре офиса.

Как видно из перечня документов, многие из них содержат информацию, составляющую служебную и коммерческую тайну. В соответствии с требованиями Федерального закона «Об аудиторской деятельности» аудиторы обязаны хранить тайну об операциях и имуществе проверяемых лиц. Так как планирование аудита является обязательной процедурой, то обязанность сохранения тайны касается и сведений, полученных при планировании.

В Стандарте «Планирование аудита» предусмотрено, что аудиторская фирма, если сочтет это целесообразным, может согласовать с руководством проверяемой организации отдельные положения общего плана и программы аудита. Однако, такое согласование не является обязательным и организация не вправе требовать, чтобы аудитор предоставлял им план и программу аудита. Аудиторская фирма также независима в выборе приемов и методов аудита, отраженных в плане и программе проверки, но при этом Стандартом установлено, что она несет полную ответственность за результаты своей работы в соответствии с разработанными ею самой планом и программой проверки.

Необходимо иметь в виду, что Стандартом предусмотрено право аудиторской фирмы отказаться от проведения аудита. Это может случиться, например, если на стадии предварительного планирования у аудиторов появляются серьезные сомнения по поводу возможности подготовки аудиторского заключения с выражением безоговорочно положительного мнения, в то время как руководство организации не проявляет должного понимания ситуации и готовности принять поправки и произвести необходимые изменения в отчетности.

Такой отказ в условиях соблюдения требований законодательства и при утверждении аудиторской фирмы общим собранием участников (акционеров) может привести к следующей проблеме. Общие собрания, как правило, 
собираются редко, и сменить аудиторскую фирму, по крайней мере оперативно, очень сложно. Поэтому менеджмент оказывается перед выбором: нарушить решение общего собрания и пригласить неутвержденную аудиторскую фирму, либо вообще не проводить обязательный аудит. Налицо правовая коллизия. Но это первое впечатление от ситуации. На самом деле утверждению аудиторской фирмы предшествует подготовительная работа, заключающаяся в предварительных переговорах с самой фирмой, членами совета директоров подлежащей проверке организации и с крупными акционерами. И отказ аудитора от проверки, как правило, обусловлен не организационными моментами, а невозможностью выдачи аудиторского заключения с выражением безоговорочно положительного мнения и нежелания менеджмента проверяемой организации исправлять отчетность. Таким образом, отказ утвержденной аудиторской компании от проверки есть тревожный сигнал для пользователей бухгалтерской отчетности организации.

Таким образом, аудит внешнеэкономической деятельности проводится на основе плана аудиторской проверки, утвержденного аудиторской организацией и согласованного с проверяемым предприятием до начала аудиторской проверки. После изучения досье клиента аудиторы приступают непосредственно к проверке.

Проведение изучения и оценки системы бухгалтерского учета и внутреннего контроля должно осуществляться в соответствии с требованиями Федерального правила (стандарта) «Оценка аудиторских рисков и внутренний контроль, осуществляемый аудируемым лицом».

Поскольку мнение аудитора об организации системы бухгалтерского учета и эффективности системы внутреннего контроля является основанием для планирования степени детальности и выборочное проведения аудиторских процедур, то, соответственно, отсутствие документирования или ненадлежащее документирование выявленных особенностей систем, а также результатов их изучения и оценки может служить показателем низкого качества аудиторских услуг. 
Наиболее приемлемыми видами документирования информации о состоянии систем бухгалтерского учета и внутрихозяйственного контроля являются вопросники.

Тесты средств контроля выполняются в целях получения аудиторских доказательств относительно эффективности:

- структуры систем бухгалтерского учета и внутреннего контроля, т.е. того, насколько хорошо они организованы с точки зрения предотвращения или обнаружения и исправления существенных искажений;

- средств внутреннего контроля в течение рассматриваемого периода.

Более полным, но и более трудоемким является способ документирования информации в виде контрольных перечней или схем. Методика составления подобных карт разрабатывается аудитором самостоятельно и практически не имеет ограничений. Основное требование к ним - их наглядность и простота. При этом необходимо отражать только операции, документы и отчеты, имеющие важность для аудиторской проверки. Применительно к импортным и экспортным операциям такие карты (схемы) отражают прохождение информации по основным этапам сделки. Это более трудоемкий, но и более достоверный способ для регистрации информации, позволяющий аудитору сформировать представление о строении ключевых процедур средств контроля.

Порядок составления контрольных схем последовательности выполнения операций подразумевает включение достаточного объема информации по внешнеэкономическим операциям, но при этом должен сохраняться принцип простоты и наглядности. В этом случае они будут пригодны для любой аудиторской проверки. Более того, данные схемы могут быть использованы и при документировании аудита на последующих этапах.

Другим положительным фактором применения контрольных перечней или схем является возможное наличие у предприятия-участника ВЭД системы документооборота как необходимого элемента учета, утверждаемого учетной политикой. Это, во-первых, облегчит задачу аудитору при составлении этих схем, во-вторых, наличие или отсутствие такой системы документооборота уже 
само по себе формирует мнение о надежности системы внутреннего контроля, и, в-третьих, составление таких схем может быть предложено как сопутствующая услуга при проведении аудита, которая при последующих проверках облегчит задачу аудитору и снизит стоимость его услуг.

С помощью данных таблицы 10 можно проанализировать систему внутреннего контроля на примере ОАО «Глэдис».

Таблица 10

Тест внутреннего контроля внешнеэкономических операций ОАО «Глэдис»

\begin{tabular}{|c|c|c|c|c|}
\hline \multirow{2}{*}{$\begin{array}{l}\text { № } \\
\text { In/II }\end{array}$} & \multirow{2}{*}{ Содержание } & \multicolumn{3}{|c|}{ Ответы } \\
\hline & & Да & Нет & Примечание \\
\hline \multicolumn{5}{|c|}{ Осуществление контроля } \\
\hline 1 & Ведется ли учет товаров по этапам их движения? & & $\mathrm{X}$ & \\
\hline 2 & $\begin{array}{l}\text { Импортные товары, прибывшие на пункты } \\
\text { пересечения границы, на основании извещения } \\
\text { приходуются в этом же месяце? }\end{array}$ & & $\mathrm{X}$ & $\begin{array}{l}\text { По мере } \\
\text { поступления на } \\
\text { склад }\end{array}$ \\
\hline 3 & $\begin{array}{l}\text { Проводится ли инвентаризация товаров по всем } \\
\text { местам хранения? }\end{array}$ & & $\mathrm{X}$ & \\
\hline \multicolumn{5}{|c|}{ Реальность } \\
\hline 4 & $\begin{array}{l}\text { Имеются ли случаи списания товаров в порядке } \\
\text { потерь во время: } \\
\text { - пути следования } \\
\text { - хранения? }\end{array}$ & & $\begin{array}{l}\mathrm{x} \\
\mathrm{x}\end{array}$ & \\
\hline 5 & $\begin{array}{l}\text { Акты на списание потерь составляются и датируются } \\
\text { числом, когда выявлена недостача? }\end{array}$ & & $\mathrm{X}$ & \\
\hline 6 & $\begin{array}{l}\text { Сравниваются ли счета иностранных поставщиков и } \\
\text { покупателей с контрактами на поставку и } \\
\text { приходными накладными? }\end{array}$ & $\mathrm{x}$ & & \\
\hline \multicolumn{5}{|c|}{ Условия } \\
\hline 7 & Контракты составляются согласно Инкотермс $2000 ?$ & $\mathrm{x}$ & & \\
\hline 8 & $\begin{array}{l}\text { Организация транспортировки осуществляется: } \\
\text { - покупателем } \\
\text {-продавцом-контрагентом } \\
\text {-с привлеченьем третьих лиц? }\end{array}$ & $\mathrm{x}$ & $\mathrm{x}$ & \\
\hline \multicolumn{5}{|c|}{ Точность } \\
\hline 9 & $\begin{array}{l}\text { Определяется ли качество и количество импортных } \\
\text { товаров на момент получения? }\end{array}$ & & $\mathrm{X}$ & \\
\hline 10 & $\begin{array}{l}\text { При передаче экспортного товара третьим лицам его } \\
\text { количество и качество перепроверяется? }\end{array}$ & & $\mathrm{X}$ & \\
\hline 11 & $\begin{array}{l}\text { Сверяются ли ежемесячные данные поставщиков со } \\
\text { счетами их кредиторской задолженности? }\end{array}$ & & $\mathrm{X}$ & \\
\hline 12 & $\begin{array}{l}\text { Проверяет ли бухгалтер счета-фактуры на } \\
\text { соответствие количества, качества, цен и сроков } \\
\text { выполнения контрактов? }\end{array}$ & $\mathrm{x}$ & & \\
\hline \multicolumn{5}{|c|}{ Классификация } \\
\hline 13 & $\begin{array}{l}\text { В рабочем плане счетов и учетной политике } \\
\text { определены наиболее характерные корреспонденции } \\
\text { по Д-т и К-т по сч. } 62 ?\end{array}$ & & $\mathrm{X}$ & \\
\hline
\end{tabular}




\begin{tabular}{|c|c|c|c|}
\hline \multicolumn{4}{|c|}{ Учет } \\
\hline 14 & $\begin{array}{l}\text { Периодически данные аналитического учета расчетов } \\
\text { с иностранными поставщиками сверяются с данными } \\
\text { синтетического учета? }\end{array}$ & $X$ & \\
\hline 15 & $\begin{array}{l}\text { Аналитический учет импортных и экспортных } \\
\text { товаров ведется по этапах их движения (товары в } \\
\text { пути за границей, товары в пути в России)? }\end{array}$ & $X$ & \\
\hline
\end{tabular}

Анализ результатов теста показывает, что в ОАО «Глэдис» практически отсутствует система внутреннего контроля, а система учета не соответствует особенностям экспортно-импортных операций. В болышинстве случаев ответы на тест носили отрицательный характер. Таким образом, аудиторская оценка неотъемлемого риска и риска средств контроля должна быть принята как высокая и в соответствии с требованиями Стандарта $\mathrm{N} 8$ при проведении проверки необходимо обеспечить самый низкий риск необнаружения.

Несмотря на то, что изучение и оценка системы бухгалтерского учета и внутрихозяйственного контроля носят подготовительный характер и осуществляются на этапе планирования, результаты их очень важны и способны оказать влияние на весь последующий ход проверки.

Поэтому возникает дилемма - проводить подробные и довольно трудоемкие процедуры для получения достоверного представления о состоянии системы внутрихозяйственного контроля или можно ограничиться лишь общими представлениями о ней, но выводы, сделанные в этом случае, могут повлечь необъективные представления о состоянии этой системы и неадекватный выбор аудиторских процедур, а как следствие - ухудшение качества оказанных услуг.

В то же время необходимость корректировки программы аудита в процессе его проведения может негативно сказаться на авторитете аудитора и его взаимоотношениях с клиентом.

Определение аудиторского риска и уровня существенности вызвано необходимостью сокращения трудовых и финансовых затрат при проведении аудита. Аудиторская фирма, как правило, не может себе позволить проверки всех первичных документов, поскольку в этом случае стоимость аудиторской 
проверки значительно возрастет и организация будет вытеснена с рынка аудиторских услуг. Поэтому характер аудиторской деятельности подразумевает, что при проведении проверки все ошибки не могут быть обнаружены, но пользователи бухгалтерской отчетности хотят быть уверенными в ее достоверности, чтобы принимать правильные экономические решения. То есть возникает проблема, как при снижении трудозатрат и стоимости проверки обеспечить обоснованность выводов.

В Федеральном стандарте "Существенность в аудите" указано, что информация является существенной, если ее пропуск или искажение может повлиять на экономические решения пользователей. В этом же стандарте указано на субъективный характер оценки существенности показателей. При рассмотрении показателей аудитор должен не пропустить и сравнительно небольшие величины, если они в своей совокупности могут оказать существенное влияние. Уровень существенности определяется аудитором как на этапе планирования, так и в ходе проверки. Этот стандарт не устанавливает способов определения уровня существенности, единых для всех аудиторов, отмечая лишь, что существенность зависит от величины показателя финансовой отчетности или ошибки.

При определении уровня существенности сначала необходимо отобрать показатели бухгалтерской отчетности, причем для каждого из показателей может быть установлен свой уровень существенности. Рекомендуется применять следующие доли от базовых показателей:

- прибыль предприятия от продаж - 5\%;

- валовый объем реализации без НДС - 2\%;

- валюта баланса - 2\%;

- собственный капитал - 10\%;

- общие затраты предприятия - 2\%.

По отчетности ОАО «Глэдис» можно построить таблицу базовых показателей: 
Таблица базовых показателей ОАО «Глэдис»

\begin{tabular}{|l|c|c|c|}
\hline \multicolumn{1}{|c|}{ Наименование показателя } & $\begin{array}{c}\text { Значение показателя в } \\
\text { бухгалтерской } \\
\text { отчетности }\end{array}$ & $\begin{array}{c}\text { Доля, } \\
\%\end{array}$ & $\begin{array}{c}\text { Значение, применяемое } \\
\text { для нахождения уровня } \\
\text { существенности }\end{array}$ \\
\hline Прибыль от продаж & 1008 & 5 & 50 \\
\hline Валовый объем реализации без НДС & 148775 & 2 & 2976 \\
\hline Валюта баланса & 68049 & 2 & 1361 \\
\hline Собственный капитал & 19705 & 10 & 1971 \\
\hline Общие затраты предприятия & 156659 & 2 & 3133 \\
\hline Уровень существенности & & & 9491 \\
\hline
\end{tabular}

На основании этого распределения существует ряд способов определения уровня существенности, например:

1. определяется среднее арифметическое от уровней существенности по всем показателям и отбрасываются значения, отличающиеся более чем на $20 \%$ от него (или отличающиеся на порядок). Затем определяется новое значение среднего арифметического, и после округления последнего в пределах 20\% получается итоговый уровень существенности;

2. выбираются наиболее характерные базовые показатели в зависимости от масштаба и вида деятельности организации.

Следует отметить, что в качестве базовых могут приниматься не только итоговые, но и промежуточные показатели (статьи или группы форм отчетности № 1 и 2), например, при проверке организации со значительным документооборотом, когда каждый аудитор проверяет свою группу счетов. При этом необходимо руководствоваться следующими приемами:

1. выборка показателей с наибольшей суммой (метод основного массива);

2. выборка показателей, характеризующихся наибольшей вероятностью появления в них ошибок (метод ключевых по риску показателей);

3. выборка показателей, ошибки или нарушения в которых (даже несущественные) могут вызвать существенные последствия (метод ключевых по последствиям показателей).

Существуют шесть основных способов расчета уровня существенности:

1 способ: Определение уровня существенности как результат комплексного расчета: 
1) расчет среднего арифметического значения: $50+2976+1361+1971+3133 / 5=1898$

2) расчет отклонения наименьшего значения:

$$
1898-50=1848 \quad 1848 / 1898 * 100 \%=97 \%
$$

3) расчет отклонения наибольшего значения: $3133-1898 / 1898 * 100 \%=65 \%$

4) расчет среднего арифметического значения: 2976+1361+1971/3=2103

5 ) данную величину можно округлить в пределах $20 \%$ в большую или меньшую сторону: в данном случае, получаем значение - примерно 2000 тыс. руб.

2 способ: За основной показатель уровня существенности применяется наименьшее значение суммы уровня существенности: балансовая прибыль-50 тыс.руб.

3 способ: Определение общего уровня существенности в целом по предприятию:

$$
\begin{aligned}
& \mathrm{S}=\mathrm{B} * \mathrm{P} / 100 \%=12654 * 2,66 / 100 \%=337 \text { тыс. руб. } \\
& \mathrm{P}=2 *(1+0,33)=2,66 \text { где } \mathrm{T}=4216 \text { тыс.руб., } \mathrm{B}=12654 \text { тыс.руб. }
\end{aligned}
$$

4 способ: Определение уровня существенности с применением формулы:

$\mathrm{G}=1,6 *$ (наибольшее значение показателей: валюта баланса или сумма доходов $)^{2 / 3}=1,6^{*}(68049)^{2 / 3}=330$ тыс.руб.

5 способ: Определение границы существенности как сумма границ существенности, установленным к значительным статьям отчетности:

так как все представленные выше статьи составляют не менее $1 \%$ в общем удельном весе, то граница уровня существенности:

$$
\text { 50+2976+1361+1971+3133/5=1898 тыс. руб. }
$$

6 способ: Расчет общей величины существенности как относительная величина базового показателя: допустим, согласно внутрифирменному стандарту определения существенности аудиторской фирмы общая абсолютная величина существенности определяется как $2 \%$ от валюты баланса:

$$
\text { 68049*2\%=1361 тыс.руб. }
$$

Общий метод аудита состоит в определении с вероятностью Р ожидаемой ошибки М (либо определении предельного значения М , которого ожидаемая 
ошибка с вероятностью Р не превысит) и сравнении ее с допустимой ошибкой (уровнем существенности) S. Ожидаемая ошибка M и допустимая ошибка S при этом могут иметь относительное (в процентах) или стоимостное (в рублях) выражение. Если $\mathrm{M}<\mathrm{S}$ (или $\mathrm{M}<\mathrm{S}$ ), то с пр вероятностью Р проверяемая информация достоверна. При этом, поскольку предметом аудита является информация, сосредоточенная, как правило, в чрезвычайно большом количестве бухгалтерских документов, то оценка ожидаемой ошибки всей совокупности документов (генеральной совокупности) почти всегда осуществляется на основе результатов проверки выборочной совокупности документов (выборки). В то же время результат проверки выборочной совокупности тем или иным методом, обеспечивающим достаточную надежность, распространяется на всю генеральную совокупность, для которой определяется ожидаемая ошибка.

Таким образом, важно не только определить величину ошибки М, но и оценить, с какой вероятностью она определена. Даже при сплошных проверках (не говоря уже о выборочных) определение ожидаемой ошибки содержит элемент случайности (аудитор может не заметить ошибку, неправильно истолковать содержание хозяйственной операции и т.п.). Следовательно, определение ожидаемой ошибки M всегда осуществляется с какой-то вероятностью: надежностью Р или риском К

Указанный риск и называется аудиторским риском. Поскольку определение ожидаемой ошибки М всегда осуществляется с каким-то риском, то аудитор должен, осуществляя проверку, оценить его возможное значение. Однако прямое определение риска (вероятности по смыслу) как отношения числа избранных событий (исходов) к общему числу всех равновозможных исходов не представляется возможным, поскольку для этого необходима информация о проверках одного объекта большим числом аудиторов или, если говорить об аудиторском риске самого аудитора, - статистика проверок абсолютно идентичных фирм.

Аудиторский риск определяется двумя способами: интуитивным 
(оценочным) или количественным.

При использовании количественного метода используется формула:

$$
\mathrm{R}_{\mathrm{a}}=\mathrm{R}_{\mathrm{H}} \times \mathrm{R}_{\mathrm{k}} \times \mathrm{R}_{\mathrm{H} / \mathrm{o}}
$$

где где $\mathrm{R}_{\mathrm{a}}$ - аудиторский риск;

$\mathrm{R}_{\mathrm{H}}$ - неотъемлемый риск;

$\mathrm{R}_{\mathrm{k}}$ - риск средств контроля;

$\mathrm{R}_{\mathrm{H} / \mathrm{o}}$ - риск необнаружения.

Неотьемлемый риск отражает подверженность остатка средств на счетах бухгалтерского учета или группы однотипных операций искажениям, которые могут быть существенными по отдельности или в совокупности с искажениями остатков средств на других счетах или групп однотипных операций при допущении отсутствия необходимых средств внутреннего контроля. В результате чего искажения остатков средств на счетах или группы однотипных операций могут составить существенную величину (по отдельности или в совокупности). Определенная величина неотъемлемого риска остается постоянной и может корректироваться только в случае выявления в ходе проверки ранее не учтенных факторов.

Риск средств контроля означает риск того, что искажение, которое может иметь место в отношении остатка счета или группы однотипных операций и которое может быть существенным по отдельности или в совокупности с искажениями других остатков счетов или однотипных операций, не будет своевременно предотвращено или обнаружено и исправлено с помощью систем бухгалтерского учета и внутреннего контроля. Риск средств контроля определяется надежностью систем бухгалтерского учета и внутреннего контроля.

Неотъемлемый риск и риск средств контроля можно условно назвать внутренним риском организации. Риском же, зависящим от аудиторской организации, является риск необнаружения. Аудиторский риск и уровень существенности находятся в обратной зависимости.

Исходя из изложенной в различных источниках аудиторской практики, 
можно сделать вывод, что приемлемым значением аудиторского риска является $5 \%$.

В отношении организации бухгалтерского учета ОАО «Глэдис» неотъемлемый риск можно принять равным 0,5, поскольку вероятности правильного и неправильного отражения импортных и экспортных операций равновелики - данный вывод можно сделать проанализировав полученные при проведении аудиторской проверки.

В отношении же системы внутреннего контроля ситуация иная: риск средств контроля следует принять равным 1, поскольку система внутреннего контроля в организации находится на низком уровне и, следовательно, искажение, которое могло бы иметь место, не может быть обнаружено и исправлено.

Из приведенной ранее формулы аудиторского риска можно определить: $\mathrm{R}_{\mathrm{a}}=\mathrm{R}_{\mathrm{H}} \times \mathrm{R}_{\mathrm{k}} \times \mathrm{R}_{\mathrm{H} / \mathrm{o}}=0,5 \times 1 \times \mathrm{R}_{\mathrm{H} / \mathrm{o}}=0,05$.

Из этого следует, что при проведении проверки ОАО «Глэдис» для обеспечения приемлемого уровня аудиторского риска необходимо обеспечить риск необнаружения на уровне не ниже $10 \%$.

Информация об экономическом субъекте, полученная в ходе предварительного планирования, оценка составляющих аудиторского риска являются основой, исходя из которой может быть сформирована стратегия аудиторской проверки. Аудитор выбирает аудиторские процедуры, которые будут применяться, определяет вид процедур, их объем и способ (метод) применения. При этом в целях оптимизации проверки необходимо принять во внимание следующие обстоятельства:

- применение статистических выборочных методов оправдано лишь при достаточно больших объемах генеральных совокупностей, а также при отсутствии информации о неравновозможности и неслучайности ошибок;

- при имеющейся информации о значимых для аудита областях целесообразно отдавать предпочтение процедурам сплошной проверки совокупностей, составляющих эти области. И, наоборот, совокупности, составляющие 
незначительные области, могут быть проверены выборочно или с помощью аналитических процедур.

Оценка аудитором размера составляющих частей аудиторского риска может изменяться в течении проведения аудита, потому что при исполнении независимых процедур проверки к сведению аудитора может дойти информация, которая значительно отличается от первоначальной. В таких случаях аудитору необходимо поменять запланированные независимые процедуры проверки, исходя из переоценки свойственного риска и риска несоответствия внутреннего контроля.

Подготовка общего плана и программы аудита является завершающей стадией планирования, при этом в общем плане отражаются основная цель и направления проверки, способ проведения аудита, установленный уровень существенности, параметры аудиторского риска, определены численность и квалификация рабочей группы аудиторов, их обязанности, ответственность и соподчиненность; указаны сроки проведения проверки, a также дата представления аудиторского заключения и детализированного отчета.

Составление программы аудита регламентируется федеральным стандартом «Планирование аудита», где, в частности, определено, что программа аудита является набором инструкций для аудитора, выполняющего проверку, а также средством контроля и проверки надлежащего выполнения работы.

Во время разработки общего плана аудитор совершает анализ следующих вопросов:

- понимание аудитором бизнеса клиента: главных факторов, которые влияют на деятельность предприятия; важных характеристик предпринимательской деятельности предприятия, его организационной структуры, процесса производства, финансового состояния, а также порядка его отчетности; распределению обязанностей между руководством предприятия. 
- понимание учета и системы внутреннего контроля: методологии и принципов бухгалтерского учета, которые использовались бухгалтерией; знание аудитора вопросов бухгалтерского учета и системы внутреннего контроля;

- определение рисков и существенности: оценка аудитором риска внутреннего контроля - эффективности системы внутрихозяйственного контроля, то есть ее способности предупреждать и выявлять ошибки на предприятии, оценка размера собственного аудиторского риска не выявления существенных ошибок и определения на основании этого важных направлений аудита;

- виды, время и полнота процедур: существование возможности оперативного внесения изменений в отдельные направления аудита; влияние информационных технологий на процесс аудита.

Общий план аудита внешнеэкономической деятельности проверяемого предприятия можно представить с помощью таблицы 12.

В программе аудита виды, содержание и время проведения запланированных аудиторских процедур должны совпадать с принятыми к работе показателями общего плана аудита.

Аудиторские процедуры - это совокупность соответствующих действий аудитора касательно проверки финансово - хозяйственной деятельности, состояния учета и финансовой отчетности.

Таблица 12

Общий план аудита внешнеэкономической деятельности ОАО «Глэдис»

\begin{tabular}{|c|c|c|c|c|}
\hline $\begin{array}{c}\text { № } \\
\text { п/п }\end{array}$ & Этапы проверки & Исполнители & $\begin{array}{c}\text { Период } \\
\text { проверки }\end{array}$ & Примечания \\
\hline 1 & $\begin{array}{c}\text { Наличие и } \\
\text { правильность } \\
\text { оформления } \\
\text { контрактов }\end{array}$ & Иванов А.А. & 1 день & $\begin{array}{c}\text { Соответствие контрактов } \\
\text { нормативам Инкотермс 2000 }\end{array}$ \\
\hline 2 & $\begin{array}{c}\text { Своевременность } \\
\text { оформления } \\
\text { операций экспортны: } \\
\text { и импортных } \\
\text { операций }\end{array}$ & Иванов А.А. & 2 дня & $\begin{array}{c}\text { Соответствие порядка оформления } \\
\text { документов учетной политике } \\
\text { законодательству РФ }\end{array}$ \\
\hline 3 & $\begin{array}{c}\text { Проверка } \\
\text { правильности } \\
\text { определения } \\
\text { таможенных сборов }\end{array}$ & Иванов А.А. & 1 день & Сооветствие Таможенному \\
Кодексу РФ
\end{tabular}




\begin{tabular}{|c|c|c|c|c|}
\hline 4 & $\begin{array}{c}\text { Налогообложение } \\
\text { экспортных и } \\
\text { импортных } \\
\text { операций }\end{array}$ & Иванов А.А. & 2 дня & $\begin{array}{c}\text { Соответствие Налоговому Кодексу } \\
\text { РФ глава 21 }\end{array}$ \\
\hline 5 & $\begin{array}{c}\text { Проверка } \\
\text { реальности } \\
\text { кредиторской и } \\
\text { дебиторской } \\
\text { задолженностей и } \\
\text { расчетов с } \\
\text { контрагентами }\end{array}$ & Иванов А.А. & 3 дня & Соответствие нормативным актам \\
& & & РФ \\
\hline 6 & $\begin{array}{c}\text { Проверка полноты } \\
\text { правильности } \\
\text { оприходования и } \\
\text { списания товаров }\end{array}$ & Иванов А.А. & 3 дня & Соответствие законодательству \\
& & & РФ \\
\hline
\end{tabular}

Аудитор сначала собирает и анализирует информацию, необходимую для оценки достоверности бухгалтерского баланса и финансовой отчетности, определяет уставные документы, выявляет отклонение состояния деятельности предприяти от того, которое предусмотрено уставными документами. Так, он изучает форму и методику бухгалтерского финансового учета, их соответсвие требованиям, которые к ним выставляются. Потом анализу полагаются записи в Главной книге, в частности, сомнительные записи, данные которых сопоставляют с регистрами аналитического учета и первичными документами.

Таблица 13

\section{Программа проведения аудита внешнеэкономической деятельности ОАО «Глэдис»}

\begin{tabular}{|c|c|c|c|c|c|}
\hline $\begin{array}{l}\text { № } \\
\text { п/ா/ா }\end{array}$ & Этапы проверки & Исполнители & $\begin{array}{c}\text { Период } \\
\text { проверки }\end{array}$ & Документы & $\begin{array}{c}\text { Аудиторские } \\
\text { процедуры }\end{array}$ \\
\hline 1 & $\begin{array}{c}\text { Наличие и } \\
\text { правильность } \\
\text { оформления } \\
\text { контрактов }\end{array}$ & Иванов А.А. & 1 день & Контракты & Исследование \\
\hline 2 & $\begin{array}{c}\text { Своевременность } \\
\text { оформления } \\
\text { операций } \\
\text { экспортных и } \\
\text { импортных } \\
\text { операций }\end{array}$ & Иванов А.А. & 2 дня & $\begin{array}{c}\text { Таможенные } \\
\text { декларации, } \\
\text { приходные, } \\
\text { расходные } \\
\text { документы }\end{array}$ & Исследование \\
\hline 3 & $\begin{array}{c}\text { Проверка } \\
\text { правильности } \\
\text { определения } \\
\text { таможенных } \\
\text { сборов }\end{array}$ & Иванов А.А. & 1 день & $\begin{array}{l}\text { Таможенные } \\
\text { декларации }\end{array}$ & Пересчет \\
\hline
\end{tabular}




\begin{tabular}{|c|c|c|c|c|c|}
\hline 4 & $\begin{array}{c}\text { Налогообложение } \\
\text { экспортных и } \\
\text { импортных } \\
\text { операций }\end{array}$ & Иванов А.А. & 2 дня & $\begin{array}{l}\text { Таможенные } \\
\text { декларации, } \\
\text { первичные } \\
\text { документы по } \\
\text { импорту и } \\
\text { экспорту }\end{array}$ & Пересчет \\
\hline 5 & $\begin{array}{c}\text { Проверка } \\
\text { реальности } \\
\text { кредиторской и } \\
\text { дебиторской } \\
\text { задолженностей и } \\
\text { расчетов с } \\
\text { контрагентами } \\
\end{array}$ & Иванов А.А. & 3 дня & $\begin{array}{c}\text { Счета-фактуры } \\
\text { поставщиков и } \\
\text { покупателей, } \\
\text { платежные } \\
\text { документы }\end{array}$ & $\begin{array}{c}\text { Инспектирование, } \\
\text { подтверждение }\end{array}$ \\
\hline 6 & $\begin{array}{c}\text { Проверка } \\
\text { полноты и } \\
\text { правильности } \\
\text { оприходования и } \\
\text { списания товаров }\end{array}$ & Иванов А.А. & 3 дня & $\begin{array}{c}\text { Счета-фактуры, } \\
\text { приходные и } \\
\text { расходные } \\
\text { документы }\end{array}$ & Инспектирование \\
\hline
\end{tabular}

В общем виде аудиторские процедуры могут быть классифицированы таким образом:

- понимание бизнеса, его организации, отрасли, в которой совершается деятельность предприятия;

• изучение и анализ информации о деятельности предприятия в целом;

- изучение форм и методов учета, оценка влияния законодательных изменений на состояние учетно-аналитического процесса;

- определение состояния объекта в натуральном, стоимостном выражении;

- контроль процесса отображения некоторых операций в учете (первичные документы, аналитические, синтетические и отчетные документы);

- рассмотрение вопросов предыдущих годов;

- рассмотрение отчетов руководства предприятия и промежуточных отчетов.

Аудиторская программа помогает руководить исполнителями аудита и контролировать их работу. В аудиторскую программу включается также перечень объектов аудита по его направлениям, а также время, которое необходимо потратить на каждое направление аудита или аудиторскую процедуру.

Из всего спектра аудиторских процедур проверки для аудита 
внешнеэкономической деятельности наиболее применимыми являются инспектирование и пересчет. Это связано в первую очередь с тем, что практически все документальные аудиторские доказательства имеют фактически смешанный характер (внешняя и внутренняя информация) и применение таких, например, процедур, как запрос и подтверждение, вряд ли оправданно.

Учитывая особенности внешнеэкономических операций, применение процедуры наблюдения также не всегда возможно. Перспективным является применение аналитических процедур.

Далее аудитор переходит к непосредственной работе по проверке внешнеэкономической деятельности.

\section{5. Сбор аудиторских доказательств}

Для получения аудиторских доказательств достоверности и законности внешнеэкономических операций можно выделить три основных направления:

- оценка соответствия операции таможенному законодательству;

- использование результатов банковского контроля;

- использование результатов внутреннего контроля аудируемого лица или непосредственная проверка порядка учета организации по этим операциям.

Проведение процедур получения аудиторских доказательств регламентировано федеральным стандартом "Аудиторские доказательства", а их документирование федеральным стандартом "Документирование аудита". Однако при этом необходимо учитывать также положения и других аудиторских стандартов.

В частности, в федеральном стандарте "Существенность в аудите" отмечается, что наряду с устанавливаемым количественным уровнем существенности, аудитором должна быть учтена возможность и качественных искажений. При этом на существенность могут оказывать влияние нормативные акты РФ, регламентирующие деятельность проверяемого объекта.

Кроме того, аудитору исходя из оптимизации его предпринимательской деятельности необходимо определить целесообразность применения 
выборочной проверки. Данное положение отражено в федеральном стандарте "Аудиторская выборка". В нем, в частности, указано на существование трех возможностей при проведении аудиторских процедур:

- отобрать все элементы (сплошная проверка);

- отобрать специфические элементы;

- отобрать отдельные элементы.

Также в этом стандарте указано на случаи, когда целесообразно применять тот или иной метод. Сплошная проверка применяется при небольшом количестве совокупности, высоком риске средств внутреннего контроля и повторяющемся характере расчетов. Отбор специфических элементов производится при достаточном понимании деятельности аудируемого лица, предварительной оценке средств внутреннего контроля и наличии характеристик и особенностей всей совокупности.

Исходя из этого, поскольку в проверяемом периоде ОАО "Глэдис" осуществлялись как импортные, так и экспортные операции, то наиболее целесообразным является проверка всех внешнеторговых операций в соответствии с программой аудита.

\section{1. Наличие и правильность оформления контрактов с иностранными контрагентами.}

При проведении данной процедуры необходимо прежде всего проверить наличие импортных и экспортных контрактов, а также соответствие их нормам и требованиям как международного, так и российского законодательства.

Таблица 14

Проверка оформления внешнеторговых контрактов

\begin{tabular}{|c|c|c|c|}
\hline $\begin{array}{c}\text { № } \\
\text { П/П }\end{array}$ & Проверяемые реквизиты & Значение & Замечание \\
\hline \multicolumn{4}{|c|}{ Общие сведения о контракте } \\
\hline 1 & Унифицированный номер & $643 / 78312019 / 003$ & Соответствует \\
\hline 2 & Дата подписания & $20.11 .2008 \Gamma$. & Соответствует \\
\hline 3 & Место подписания & Иран, г.Малаир & Соответствует \\
\hline 4 & $\begin{array}{ll}\text { Официальное } & \text { наименование } \\
\text { контрагента, страна }\end{array}$ & $\begin{array}{l}\text { Компания Голден Драйд Фруйтс } 555 \\
\text { Малаир, г.Малаир Иран }\end{array}$ & Соответствует \\
\hline 5 & $\begin{array}{l}\text { Адреса, реквизиты, банковские } \\
\text { счета, подписи, печати }\end{array}$ & Указаны полностью & Соответствует \\
\hline
\end{tabular}




\begin{tabular}{|c|c|c|c|}
\hline \multicolumn{4}{|c|}{ Предмет договора } \\
\hline 6 & $\begin{array}{l}\text { Наименование и характеристики } \\
\text { товара }\end{array}$ & $\begin{array}{l}\text { В соответствии со спецификацией- } \\
\text { приложением }\end{array}$ & Соответствует \\
\hline 7 & Момент перехода прав & FOВ-Иранский порт(ИНКОТЕРМС) & Соответствует \\
\hline 8 & Порядок и сроки поставки & Партиями до 31.12.2008г. & Соответствует \\
\hline 9 & Качество товара & По образцам & Соответствует \\
\hline 10 & Упаковка/маркировка & $\begin{array}{l}\text { Обеспечивающая } \\
\text { сохранность/подробная }\end{array}$ & Соответствует \\
\hline 11 & Общая сумма & 950000 долларов США & Соответствует \\
\hline 12 & Цена товара & $\begin{array}{l}\text { В соответствии со спецификацией- } \\
\text { приложением }\end{array}$ & Соответствует \\
\hline 13 & $\begin{array}{lll}\text { Приложения } \\
\text { партию }\end{array}$ & Счета продавца & Соответствует \\
\hline \multicolumn{4}{|c|}{ Условия платежа } \\
\hline 14 & Порядок платежа & $\begin{array}{l}\text { Банковским переводом, } \\
\text { встречными поставками }\end{array}$ & Соответствует \\
\hline 15 & Срок платежа & $\begin{array}{l}\text { В течение } 90 \text { календарных дней с } \\
\text { даты поставки }\end{array}$ & Соответствует \\
\hline 16 & Штрафные санкции & $\begin{array}{l}\text { 0,5\%от суммы неоплаченного товара } \\
\text { за каждый день просрочки }\end{array}$ & Соответствует \\
\hline \multicolumn{4}{|c|}{ Условия поставки } \\
\hline 17 & Условия поставки & FOВ-Иранский порт (ИНКОТЕРМС) & Соответствует \\
\hline 18 & Место доставки & г.Астрахань & Соответствует \\
\hline 19 & Извещение на отгрузку & Заказ & Соответствует \\
\hline 20 & Штрафные санкции & $\begin{array}{l}\text { За несоответствие качества штраф } \\
0,5 \% \text { от стоимости товара }\end{array}$ & Соответствует \\
\hline \multicolumn{4}{|c|}{ Документация } \\
\hline 21 & $\begin{array}{l}\text { Товаросопроводительные } \\
\text { документы }\end{array}$ & $\begin{array}{l}\text { Инвойс, } \\
\text { коносамент, } \text { упаковочный товарн-транспортная } \\
\text { накладная, сертификат качества, } \\
\text { сертификат происхождения, ГТД }\end{array}$ & Соответствует \\
\hline 22 & Гарантия на товар & Отсутствует & Соответствует \\
\hline 23 & Арбитраж и применимое право & Российское, ТПП & Соответствует \\
\hline 24 & Форс-мажор & Освобождение от ответственности & Соответствует \\
\hline
\end{tabular}

Сложность данной проверки заключается в том, что фактически строгой регламентации внешнеторговых контрактов не существует, и поэтому важно профессиональное суждение аудитора и степень его компетентности во внешнеэкономической деятельности. Ориентиром могут служить "Рекомендации по минимальным требованиям к обязательным реквизитам и форме внешнеторговых контрактов", утвержденные во исполнение распоряжения Правительства РФ от 16.01.1996 N 55-р и рекомендованные письмом Центрального банка РФ от 15.07.1996 N 300 для применения всем уполномоченным банкам.

Также очень важным является наличие в контракте ссылок на формализованные международные документы - конвенции, ИНКОТЕРМС и 
т.П., поскольку эти ссылки могут оказать существенное влияние на оформление внешнеторговых сделок.

Для документирования данной процедуры можно составить таблицу соответствия основных положений проверяемого контракта основным требованиям, предъявляемым к таким документам. Каждый контракт проверяется по данной аналогии.

По результатам данной процедуры можно сделать вывод о соответствии внешнеэкономического контракта ОАО "Глэдис" необходимым требованиям.

При проверке остальных экспортных и импортных контрактов нарушений и несоответствий выявлено не было.

\section{2. Своевременность отражения операций по двиюению экспортного и} импортного товара

Особенностью проведения данной процедуры в отношении импорта и экспорта товаров является необходимость сопоставления данных оприходования и списания товаров с данными таможенных деклараций. Но вместе с тем необходимо в первую очередь учитывать условия перехода прав собственности, оговоренные во внешнеэкономическом контракте. Особое внимание необходимо обратить на соответствие при этом условиям ИНКОТЕРМС. Часто дата таможенной очистки товаров, применяемая обычно бухгалтерами при принятии импортных товаров к учету или дата списания, и дата перехода прав собственности на них не всегда совпадают.

Так, примененное в контракте N 643/78312019/003 ОАО «Глэдис» условие FOB-Иранский порт, означает в соответствии с Международными правилами толкования торговых терминов, что товар "свободен на борту" (free on board = FOB), т.е. продавец считается выполнившим свое обязательство по поставке с момента перехода товара через поручни судна в порту отгрузки. Следовательно, дата перехода товара в собственность покупателя определяется не датой выпуска российскими таможенными органами, а датой расписки капитана (коносамента) торгового судна при взятии груза на борт в порту отгрузки. 
Сравнение данных коносамента целесообразно проводить с данными ГТД, данными бухгалтерского учета организации и для документирования свести это в таблицу. Для выбора анализируемых счетов синтетического учета необходимо учесть положения действующей учетной политики организации. Например, учетной политикой ОАО «Глэдис» предусмотрен учет приобретения материальных ценностей по их фактической себестоимости на счете 41 "Товары", поэтому помимо карточек количественно-стоимостного учета целесообразно проверить отражение операции импорта и на данном бухгалтерском счете и корреспондирующем с ним счете. Пример такого рабочего документа приведен в таблице 15.

Таблица 15

\section{Проверка своевременности оформления внешнеторговых операций}

\begin{tabular}{|c|c|c|c|c|c|}
\hline \multirow{2}{*}{$\begin{array}{l}\text { № } \\
\Pi / \Pi\end{array}$} & \multirow[t]{2}{*}{ Источник информации } & \multicolumn{3}{|c|}{ Дата партии товара } & \multirow{2}{*}{$\begin{array}{l}\text { Замечание } \\
\text { аудитора }\end{array}$} \\
\hline & & 01.12 .2008 г. & 10.12.2008г. & 25.12 .2008 г. & \\
\hline 1 & Коносамент & 21.11 .2008 г. & 21.11.2008г. & 21.11.2008г. & \\
\hline 2 & Инвойс продавца & 21.11 .2008 г. & 21.11 .2008 г. & 21.11 .2008 г. & \\
\hline 3 & Упаковочный лист & 21.11 .2008 г. & 21.11.2008г. & 21.11.2008г. & \\
\hline 4 & ГТД & 01.12 .2008 г. & 10.12.2008г. & 25.12 .2008 г. & \\
\hline 5 & $\begin{array}{l}\text { Карточка количественно- } \\
\text { стоимостного учета }\end{array}$ & 01.12 .2008 г. & 10.12.2008г. & 25.12 .2008 г. & $\begin{array}{c}\mathrm{He} \\
\text { соответствует }\end{array}$ \\
\hline 6 & Счет 41 & 01.12 .2008 г. & 10.12.2008г. & $25.12 .2008 \Gamma$ & $\begin{array}{c}\mathrm{He} \\
\text { соответствует }\end{array}$ \\
\hline
\end{tabular}

Анализируя таблицу 15, можно сделать вывод о том, что организацией несвоевременно отражено приобретение импортных товаров. В течение непродолжительного времени товары, собственность на которые уже перешла к ОАО «Глэдис» и по которым возникла задолженность перед продавцом, находились в пути (перевозка из Ирана считается достаточно рискованной операцией) без отражения этого в бухгалтерском учете организации.

Кроме того, проводя инспектирование по данной процедуре, очевидно, что организация при этом оплатила транспортировку и страховку данных товаров при перевозке, фактически не отражая их приобретение.

Данное обстоятельство необходимо учесть при проведении последующих 
процедур. Установленные дополнительные данные повышают риск искажения информации, и их целесообразно для учета в дальнейшем также свести в отдельную таблицу 16.

Таблица 16

\section{Дополнительная информация о внешнеторговых операциях}

\begin{tabular}{|c|c|c|c|c|}
\hline $\begin{array}{l}\text { № } \\
\Pi / \Pi\end{array}$ & Дата партии & $\begin{array}{c}\text { Дополнительные затраты } \\
\text { отраженные в бухгалтерском } \\
\text { учете }\end{array}$ & Содержание операции & $\begin{array}{c}\text { Документы, } \\
\text { необходимые для } \\
\text { анализа }\end{array}$ \\
\hline 1 & $01.12 .2008 \Gamma$. & Д-т 41 К-т 76 & $\begin{array}{c}\text { Оплата федеральных } \\
\text { платежей }\end{array}$ & $\begin{array}{c}\text { ГТД, платежные } \\
\text { документы }\end{array}$ \\
\hline 2 & 01.12 .2008 г. & Д-т 41 К-т 76 & $\begin{array}{c}\text { Дополнительные } \\
\text { расходы на } \\
\text { транспортировку }\end{array}$ & $\begin{array}{c}\text { Договор } \\
\text { транспортировки }\end{array}$ \\
\hline 3 & 01.12 .2008 г. & Д-т $44 \quad$ К-т 76 & $\begin{array}{c}\text { Страхование } \\
\text { контейнера }\end{array}$ & $\begin{array}{c}\text { Договор } \\
\text { страхования, } \\
\text { страховой полис }\end{array}$ \\
\hline 4 & 01.12 .2008 г. & Д-т 44 К-т 76 & $\begin{array}{c}\text { Дополнительные } \\
\text { расходы на } \\
\text { транспортировку }\end{array}$ & $\begin{array}{c}\text { Договор } \\
\text { транспортировки }\end{array}$ \\
\hline 5 & $01.12 .2008 \Gamma$. & Д-т $44 \quad$ К-т 76 & Таможенный сбор & $\begin{array}{c}\text { ГТД, платежные } \\
\text { документы }\end{array}$ \\
\hline
\end{tabular}

По остальным партиям товара были осуществлены аналогичные операции. Так как в бухгалтерии ОАО «Глэдис» все внешнеторговые операции в программе оформляются с помощью типовых операций. На основании этой таблицы необходимо провести инспектирование дополнительных источников информации.

\section{3. Проверка правильности определения таможенной стоимости}

Таможенная стоимость является исходной величиной для исчисления таможенных платежей, уплачиваемых при ввозе товаров на таможенную территорию России, поэтому к проверке правильности еe определения необходимо отнестись с особой тщательностью, поскольку неверное ее определение может привести к неполной уплате таможенных платежей и, как следствие, применению штрафных санкций к организации при проведении таможенных ревизий (ст. 376 Таможенного кодекса РФ).

Основным нормативным документом, регламентирующим по рядок определения таможенной стоимости, является Закон РФ "О таможенном тарифе". 
Определение таможенной стоимости товаров, ввозимых на таможенную территорию РФ, рассмотрено в Главе 2 данного учебного пособия.

С помощью данных таблицы 17 можно рассмотреть методику проверки определения таможенной стоимости.

Таблица 17

Проверка определения таможенной стоимости

\begin{tabular}{|c|c|c|c|c|c|}
\hline \multirow[t]{2}{*}{$\begin{array}{l}\text { № } \\
\Pi / \Pi\end{array}$} & \multirow[t]{2}{*}{ Источник информации } & \multicolumn{3}{|c|}{$\begin{array}{l}\text { Включение в таможенную стоимость партии } \\
\text { товара, поступившей (дата) }\end{array}$} & \multirow[t]{2}{*}{$\begin{array}{l}\text { Замечание } \\
\text { аудитора }\end{array}$} \\
\hline & & $01.12 .2008 г$ & $10.12 .2008 г$ & 25.12 .2008 г. & \\
\hline \multicolumn{6}{|c|}{ Цена сделки } \\
\hline 1 & Инвойсы продавца & $\begin{array}{c}28988 \\
\text { дол.США= } \\
803231,39 \\
\text { руб. }\end{array}$ & $\begin{array}{c}27972 \\
\text { дол.США= } \\
768922,32 \\
\text { руб. }\end{array}$ & $\begin{array}{c}34319 \\
\text { дол.США= } 945 \\
289,40 \text { руб. }\end{array}$ & Соответствует \\
\hline \multicolumn{6}{|c|}{ Расходы по доставке } \\
\hline 2 & 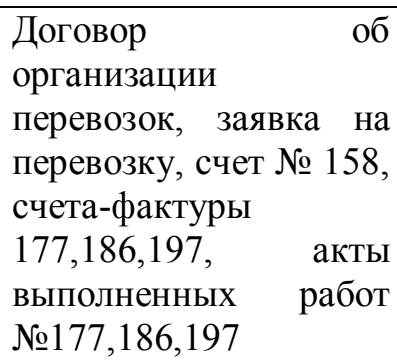 & $\begin{array}{l}\text { До границы } \\
\text { России }\end{array}$ & $\begin{array}{l}\text { До границы } \\
\text { России }\end{array}$ & $\begin{array}{l}\text { До границы } \\
\text { России }\end{array}$ & Соответствует \\
\hline 3 & Данные ДТС, ГТД & 140209,99руб. & 136319,60руб. & 135528,00руб. & \\
\hline \multicolumn{6}{|c|}{ Стоимость страхования } \\
\hline 4 & $\begin{array}{l}\text { Договор страхования } \\
\text { грузов, заявление на } \\
\text { страхование, } \\
\text { страховые полисы }\end{array}$ & 2 442,34 руб. & 2 356,74 руб. & 2891,50 руб. & \multirow[t]{2}{*}{$\begin{array}{l}\text { Не соответствует } \\
\text { законодательству }\end{array}$} \\
\hline 5 & Данные ДТС и ГТД & Нет & Нет & Нет & \\
\hline \multicolumn{6}{|c|}{ Таможенная стоимость } \\
\hline 6 & $\begin{array}{l}\text { Контрольное значение } \\
\text { по } \\
\text { проверки }\end{array}$ & 946332,88руб. & 907598,65руб. & 1083260,10руб. & \multirow{3}{*}{$\begin{array}{l}\text { Риск применения } \\
\text { штрафных } \\
\text { санкций }\end{array}$} \\
\hline 7 & $\begin{array}{l}\text { Заявленная таможенным } \\
\text { органом стоимость }\end{array}$ & 943441,38руб. & 905241,91руб. & 1080817,88руб. & \\
\hline 8 & $\begin{array}{l}\text { Занижение таможенной } \\
\text { стоимости }\end{array}$ & 2891,50 руб. & 2356,74 руб. & 2 442,34 руб. & \\
\hline
\end{tabular}

Однако следует отметить, что по сложившейся практике работы таможенных органов методы определения таможенной стоимости по стоимости с однородными и идентичными товарами, а также методы сложения и вычитания применяются крайне редко. Обусловлено это наличием достаточно жестких требований к наличию информации о товарах, при которых они могут применяться. Как правило, получение такой информации связано с большими трудностями (либо она не является объективной), и таможенные органы при 
невозможности применения первого метода переходят сразу к наиболее универсальному по части источников данных - резервному методу.

Учитывая вышеизложенные требования, аудитор должен на основании первичных документов не только определить правильность исчисления аудируемым лицом таможенной стоимости в соответствии с избранным им методом (как правило, первым), но и оценить обоснованность применения данного метода, а также полноту включенных в таможенную стоимость компонентов.

Для документирования данной процедуры можно составить таблицу, отражающую достоверность отражения в таможенной стоимости всех еe составляющих, и сравнить полученные данные с декларацией таможенной стоимости (ДТС), подаваемой вместе с ГТД при декларировании товаров.

По результатам данной процедуры можно сделать вывод, что ОАО «Глэдис» неверно определена таможенная стоимость импортных товаров вследствие неполного включения в нее компонентов, предусмотренных Законом РФ "О таможенном тарифе".

\section{4. Налогообложение внешнеторговых операций}

Налогообложение импортных товаров производится путем уплаты причитающихся таможенных платежей при таможенном оформлении.

Состав таможенных платежей рассмотрен в Главе 2 данного учебного пособия.

Товар ОАО «Глэдис» согласно законодательству не входит в перечень подакцизных товаров.

При проведении проверки налогообложения внешнеторговых операций необходимо прежде всего знать их таможенную стоимость, ставки таможенных пошлин, акцизов и НДС.

Применяя вычисленные данные о таможенной стоимости ОАО «Глэдис» товаров, а также приведенные ранее формулы определения таможенных платежей, можно составить таблицу их сопоставления с данными, заявленными 
организацией таможенному органу и отраженными впоследствии на счетах бухгалтерского учета.

Таблица 18

Проверка таможенных платежей (в рублях)

\begin{tabular}{|c|c|c|c|c|c|}
\hline \multirow{2}{*}{$\begin{array}{l}\text { № } \\
\text { ח/п }\end{array}$} & \multirow[t]{2}{*}{ Показатель } & \multicolumn{3}{|c|}{ Партия товара, полученная (дата) } & \multirow{2}{*}{$\begin{array}{c}\text { Замечания } \\
\text { аудитора }\end{array}$} \\
\hline & & $01.12 .2008 \Gamma$ & $10.12 .2008 \Gamma$ & $25.12 .2008 \Gamma$ & \\
\hline \multicolumn{6}{|c|}{ Таможенная стоимость } \\
\hline 1 & Контрольное значение & 946332,88 & 907598,65 & 1083260,1 & \multirow{3}{*}{ Занижена } \\
\hline 2 & Заявлено в ГТД & 943441,38 & 905241,91 & 1080817,88 & \\
\hline 3 & Разница & 2891,50 & 2356,74 & 2442,34 & \\
\hline \multicolumn{6}{|c|}{ Таможенная пошлина } \\
\hline 4 & Контрольное значение & 141949,93 & 136139,8 & 162489,02 & \multirow{3}{*}{ Занижена } \\
\hline 5 & Заявлено в ГТД & 141616,15 & 135786,3 & 162122,70 & \\
\hline 6 & Разница & 333,78 & 353,50 & 166,32 & \\
\hline \multicolumn{6}{|c|}{ Акциз } \\
\hline 7 & Контрольное значение & & Не облагаетс & & \multirow{3}{*}{ - } \\
\hline 8 & Заявлено в ГТД & - & - & - & \\
\hline 9 & Разница & - & - & - & \\
\hline \multicolumn{6}{|c|}{ Налог на добавленную стоимость (НДС) } \\
\hline 10 & Контрольное значение & 195890,90 & 187872,90 & 224234,84 & \multirow{3}{*}{ Занижен } \\
\hline 11 & Заявлено в ГТД & 195292,29 & 187385,09 & 223729,38 & \\
\hline 12 & Разница & 598,6 & 487,83 & 505,46 & \\
\hline \multicolumn{6}{|c|}{ Сбор за таможенное оформление } \\
\hline 13 & Контрольное значение & 2000 & 2000 & 2000 & \multirow[t]{3}{*}{ Соответствует } \\
\hline 14 & Заявлено в ГТД & 2000 & 2000 & 2000 & \\
\hline 15 & Разница & 0 & 0 & 0 & \\
\hline \multicolumn{6}{|c|}{ Всего таможенных платежей } \\
\hline 16 & Контрольное значение & 339840,83 & 326012.72 & 388723.86 & \multirow{3}{*}{$\begin{array}{c}\text { Недоплата } \\
\text { таможенных } \\
\text { платежей } \\
2645,50 \text { руб. }\end{array}$} \\
\hline 17 & Заявлено в ГТД & 338908,44 & 325171,39 & 387852,08 & \\
\hline 18 & Разница & 932,39 & 841,33 & 871,78 & \\
\hline
\end{tabular}

По результатам данной процедуры следует вывод, что организацией не доплачены таможенные платежи по каждой из поставок импортных товаров. Причем в данном случае хотя искажение по каждой поставке ниже уровня существенности, их суммарная величина уже является существенным искажением. К тому же подвержена проверке была лишь партия импортных товаров. А в течение года их количество было намного больше. Более того, такие ошибки являются существенными уже в силу того, что влекут недоплату таможенных платежей в результате занижения таможенной стоимости и образуют состав правонарушения, ответственность за которое предусмотрена ст. 16.2 Кодекса РФ об административных правонарушениях. Можно 
рекомендовать доплатить указанные платежи в добровольном порядке во избежание применения штрафных санкций.

5. Проверка реальности кредиторской и дебиторской задолюеенностей и расчетов с контрагентами

Проверку кредиторской и дебиторской задолженности можно осуществить сопоставлением выставленных счетов-фактур (инвойсов) за поставленные импортные товары и связанные с импортом и экспортом услуги. При этом необходимо уделить внимание обоснованности отнесения тех или иных услуг к операциям, связанным с внешнеторговыми операциями.

Кроме того, ввиду особой значимости желательно получение доказательств расчетов с иностранным поставщиком из внешних источников.

Например, при проведении проверки ОАО «Глэдис» получен подтверждающий документ - ведомость банковского контроля по проверяемой сделке, что значительно повышает надежность аудиторских доказательств. Рабочим документом по данной процедуре может служить таблица 19.

По результатам анализа таблицы 19 можно сделать вывод, что ОАО «Глэдис» имеет подтвержденную кредиторскую задолженность перед поставщиком импортных товаров по двум поставкам. Срок оплаты по данным поставкам не истек. Расчеты по поставке, срок расчетов по которой близок к завершению на момент проверки, произведены полностью.

Таким образом, штрафных санкций по расчетам с иностранным контрагентом не предвидится. По остальным поставщикам услуг, а также по расчетам с бюджетом задолженности ОАО «Глэдис» не имеет.

Имеется даже небольшая предоплата услуг страховой компании и расчетов по таможенным платежам, что свидетельствует о намерении организации продолжать деятельность и исполнять свои обязательства.

Тем не менее по результатам данной процедуры можно рекомендовать произвести зачет недоплаченных таможенных платежей за счет аванса в пользу таможенных органов. 
Таблица 19

Проверка расчетов с иностранными контрагентами

\begin{tabular}{|c|c|c|c|c|c|c|c|c|}
\hline \multirow{2}{*}{$\begin{array}{l}\text { № } \\
\Pi / \\
\Pi \\
\Pi\end{array}$} & \multirow{2}{*}{$\begin{array}{c}\text { Поставщи } \\
\text { к товаров } \\
\text { и услуг }\end{array}$} & \multicolumn{2}{|c|}{ Документ к оплате } & \multicolumn{2}{|c|}{$\begin{array}{c}\text { Платежный } \\
\text { документ }\end{array}$} & \multirow[t]{2}{*}{$\begin{array}{c}\text { Подтверждающи } \\
\text { й документ }\end{array}$} & \multirow[t]{2}{*}{$\begin{array}{l}\text { Сальд } \\
\text { о }\end{array}$} & \multirow{2}{*}{$\begin{array}{c}\text { Внешнее } \\
\text { подтверждени } \\
\text { е }\end{array}$} \\
\hline & & Номер & Сумма & Номер & Сумма & & & \\
\hline 1 & $\begin{array}{c}\text { Страховая } \\
\text { компания } \\
\text { «РИМ» }\end{array}$ & $\begin{array}{c}\text { Счет } \\
\text { №257 от } \\
10.09 .08 \text { г }\end{array}$ & $\begin{array}{l}10000 \\
\text { руб. }\end{array}$ & $\begin{array}{c}\Pi / \Pi \\
\text { №174 } \\
\text { От } \\
14.09 .0 \\
8 \text { г. }\end{array}$ & $\begin{array}{l}10000 \\
\text { руб. }\end{array}$ & $\begin{array}{c}\text { Страхование } \\
\text { подписи № } \\
07-6841 \\
07-6842 \\
07-6843 \\
7690,58(\text { аванс) }\end{array}$ & -2309 & - \\
\hline 2 & $\begin{array}{c}\text { Страховая } \\
\text { компания } \\
\text { «РИМ» }\end{array}$ & $\begin{array}{c}\text { Счет } \\
\text { №284 от } \\
07.11 .08 \text { г }\end{array}$ & $\begin{array}{l}10000 \\
\text { руб. }\end{array}$ & \begin{tabular}{l}
\multicolumn{1}{c}{ П/П } \\
№204 \\
от \\
10.11 .0 \\
8 г. \\
\end{tabular} & $\begin{array}{l}10000 \\
\text { руб. }\end{array}$ & Нет (аванс) & $10 \overline{0}$ & - \\
\hline 3 & $\begin{array}{c}\text { Компания } \\
\text { Голден } \\
\text { Драйд } \\
\text { Фруйтс } \\
555\end{array}$ & $\begin{array}{c}\text { Счет №5 } \\
\text { от } \\
05.11 .08 \text { г } \\
\text { Счет- } \\
\text { фактура } \\
\text { №74 от } \\
\text { 15.11.08г }\end{array}$ & $\begin{array}{c}\text { 5086дол } \\
. \text { США= } \\
186320 \\
\text { руб. }\end{array}$ & $\begin{array}{c}\text { П/ח } \\
\text { №207 } \\
\text { От } \\
12.11 .0 \\
8 \text { г. }\end{array}$ & $\begin{array}{l}186320 \\
\text { руб. }\end{array}$ & $\begin{array}{c}\text { Товарная } \\
\text { накладная № } \\
65841 / 4516 / 5781 \\
\text { от } 15.11 .08 \text { г. }\end{array}$ & 0 & - \\
\hline 4 & $\begin{array}{c}\text { Компания } \\
\text { Голден } \\
\text { Драйд } \\
\text { Фруйтс } \\
555\end{array}$ & $\begin{array}{c}\text { Счет } \\
\text { №14 от } \\
\text { 17.11.08г } \\
\text { Счет- } \\
\text { фактура } \\
\text { №89 от } \\
\text { 30.11.08г }\end{array}$ & $\begin{array}{c}\text { 5086дол } \\
. \text { США= } \\
186320 \\
\text { руб. }\end{array}$ & $\begin{array}{c}\text { П/П } \\
\text { №218 } \\
\text { От } \\
27.11 .0 \\
8 \text { г. }\end{array}$ & $\begin{array}{l}186320 \\
\text { руб. }\end{array}$ & $\begin{array}{c}\text { Товарная } \\
\text { накладная № } \\
65974 / 1586 / 8451 \\
\text { от } 30.11 .08 \text { г. }\end{array}$ & 0 & - \\
\hline 5 & $\begin{array}{c}\text { ООО } \\
\text { «АХТАР } \\
\text { ДЖОНУБ } \\
»\end{array}$ & $\begin{array}{c}\text { Инвойс } \\
\text { №45812 } \\
\text { ТН } \\
23.12 .08 \text { г }\end{array}$ & $\begin{array}{c}28988 \\
\text { дол.СШ } \\
\text { А }\end{array}$ & $\begin{array}{c}\text { Поруче } \\
\text { ние на } \\
\text { перево } \\
\text { д } \\
\text { валюты } \\
\text { №1 от } \\
28.12 .0 \\
\text { 8г. } \\
\end{array}$ & $\begin{array}{c}28988 \\
\text { дол.СШ } \\
\text { А }\end{array}$ & $\begin{array}{c}\text { ГТД } \\
\text { №10110060/2203 } \\
05 / 0001151\end{array}$ & 0 & $\begin{array}{c}\text { Выписка } \\
\text { банковского } \\
\text { контроля }\end{array}$ \\
\hline 6 & $\begin{array}{c}\text { ООО } \\
\text { «АХТАР } \\
\text { ДЖОНУБ } \\
» \\
\end{array}$ & $\begin{array}{c}\text { Инвойс } \\
\text { №45813 } \\
\text { ТН } \\
23.12 .08 \text { г }\end{array}$ & $\begin{array}{c}27972 \\
\text { дол.СШ } \\
\text { А }\end{array}$ & - & - & $\begin{array}{c}\text { ГТД } \\
\text { №10110060/5421 } \\
77 / 4514251\end{array}$ & $\begin{array}{c}27972 \\
\text { дол.С } \\
\text { ША }\end{array}$ & $\begin{array}{c}\text { Срок оплаты } \\
\text { 24.01.09г. }\end{array}$ \\
\hline 7 & $\begin{array}{c}\text { ООО } \\
\text { «АХТАР } \\
\text { ДЖОНУБ } \\
» \\
\end{array}$ & $\begin{array}{c}\text { Инвойс } \\
\text { №45814 } \\
\text { ТН } \\
23.12 .08 \text { г }\end{array}$ & $\begin{array}{c}34319 \\
\text { дол.СШ } \\
\text { А }\end{array}$ & - & - & $\begin{array}{c}\text { ГТД } \\
\text { №10110060/1456 } \\
14 / 4521452\end{array}$ & $\begin{array}{c}34319 \\
\text { дол.С } \\
\text { ША }\end{array}$ & $\begin{array}{c}\text { Срок оплаты } \\
\text { 01.02.09г. }\end{array}$ \\
\hline
\end{tabular}

Дебиторская задолженность по иностранным покупателям также отсутствуем, имеется лишь дебиторская задолженность на внутреннем рынке. Желательно данную задолженность истребовать. 


\section{6. Проверка полноты и правильности оприходования и списания}

\section{товаров}

В ходе проведения данной процедуры необходимо получить достаточные доказательства того, что все импортные товары, по которым признана кредиторская задолженность, были не только отгружены, но и прошли таможенную очистку, а также были приняты организацией к учету. Невыполнение этих условий влечет два существенных риска: во-первых, расхождение в количестве импортированных товаров и товаров, задекларированных таможенным органом, влечет санкции даже более серьезные, чем неверное определение стоимости, и, во-вторых, получение, например, товаров в меньшем количестве может привести просто к превышению этой кредиторской задолженности над дебиторской при продаже этих товаров на российском рынке, т.е. невозможности организации рассчитаться по своим долгам (основная деятельность ОАО «Глэдис» - оптовая торговля).

Таблица 20

\section{Проверка полноты и правильности оприходования и списания товаров}

\begin{tabular}{|c|c|c|c|c|c|c|c|c|}
\hline \multirow[t]{2}{*}{$\begin{array}{l}\text { № } \\
\Pi / \Pi\end{array}$} & \multirow[t]{2}{*}{$\begin{array}{c}\text { Наименование } \\
\text { товара }\end{array}$} & \multicolumn{2}{|c|}{$\begin{array}{c}\text { Отгружено } \\
\text { поставщиком }\end{array}$} & \multicolumn{2}{|c|}{$\begin{array}{c}\text { Представлено при } \\
\text { таможенном } \\
\text { оформлении }\end{array}$} & \multicolumn{2}{|c|}{$\begin{array}{l}\text { Оприходовано } \\
\text { Д-т } 41 \text { К-т } 60\end{array}$} & \multirow[t]{2}{*}{$\begin{array}{l}\text { Замечания } \\
\text { аудитора }\end{array}$} \\
\hline & & $\begin{array}{l}\text { Коли- } \\
\text { чество }\end{array}$ & Стоимость & $\begin{array}{l}\text { Коли- } \\
\text { чество }\end{array}$ & Стоимость & $\begin{array}{l}\text { Коли- } \\
\text { чество }\end{array}$ & Стоимость & \\
\hline \multicolumn{9}{|c|}{ Партия 01.12.2008г. } \\
\hline 1 & Изюм & 327 & 16518 & 327 & \multirow{3}{*}{$\begin{array}{c}28088 \\
\text { дол.США= } \\
803231 \\
\text { Руб. }\end{array}$} & 327 & 434326,15 & \multirow{3}{*}{ Соответствует } \\
\hline 2 & Финики & 278 & 11570 & 278 & & 278 & 368905,24 & \\
\hline 3 & Всего партия & 605 & 28088 & 605 & & 605 & 803231,39 & \\
\hline \multicolumn{9}{|c|}{ Партия 10.12.2008г. } \\
\hline 4 & Изюм & 690 & 19834 & 690 & \multirow{3}{*}{$\begin{array}{c}27972 \\
\text { дол.США= } \\
768922 \text { руб. }\end{array}$} & 690 & 510648,20 & \multirow{3}{*}{ Соответствует } \\
\hline 5 & Финики & 350 & 8138 & 350 & & 350 & 258344,12 & \\
\hline 6 & Всего партия & 1040 & 27972 & 1040 & & 1040 & 768992,32 & \\
\hline \multicolumn{9}{|c|}{ Партия 25.12.2008г. } \\
\hline 7 & Изюм & 270 & 16143 & 270 & \multirow{3}{*}{$\begin{array}{c}34319 \\
\text { дол.США= } \\
945289 \text { руб. }\end{array}$} & 270 & 445500,40 & \multirow[t]{3}{*}{ Соответствует } \\
\hline 8 & Финики & 304 & 18176 & 304 & & 304 & 499789,00 & \\
\hline 9 & Всего партия & 574 & 34319 & 574 & & 574 & 945289,40 & \\
\hline
\end{tabular}

Экспортные операции проверяются аналогичным методом, разница заключается лишь в замене графы «Оприходовано» на «Списано» и соответствующими проводками Д-т 90 К-т 41. У ОАО «Глэдис» при проверке 
задолженности покупателей по внешнеторговым контрактам по экспорту обнаружено не было.

По результатам данной процедуры можно сделать вывод, что все импортные товары получены и учтены организацией в точном соответствии с документами поставщика, т.е. кредиторская задолженность соответствует полученным материальным ценностям. Кроме того, поскольку при проведении данной процедуры использованы доказательства повышенной степени надежности - ГТД, проверенные российскими таможенными органами, а также административные таможенные документы страны вывоза (Иран), точность и полноту соответствия учета товаров и кредиторской задолженности по ним можно считать достоверной.

Первый документ, подлежащий изучению, - приказ об учетной политике предприятия, из которого аудитор должен получить информацию о способах ведения бухгалтерского учета тех операций, которые в соответствии с законодательством могут отражаться несколькими способами. Особое внимание аудитор обращает на организацию налогового учета и систему внутреннего контроля, закрепленную учетной политикой предприятия.

Если аудитор не находит необходимую ему информацию в приказе об учетной политике предприятия, то сведения, представляемые исполнительному органу, должны содержать рекомендации аудитора по внесению в нее изменений в текущем отчетном периоде. Окончательные рекомендации о вносимых в учетную политику предприятия изменениях могут быть даны аудитором только после завершения аудиторской проверки, поскольку именно тогда аудитор сможет сделать объективные выводы и внести конкретные предложения, для того чтобы учетная политика соответствовала особенностям бухгалтерского учета внешнеэкономической деятельности предприятия. После этого аудитор формирует предварительное мнение о соответствии учетной политики действующему законодательству по бухгалтерскому учету, определяет объекты бухгалтерского учета, которые имеют несколько способов 
отражения в соответствии с законодательством, а предприятие не заявило о том, какой способ учета выбирает.

При изучении учетной политики предприятия можно использовать также готовые варианты ответов, оформленные в виде таблицы. Анкета и таблица представляют собой часть рабочей документации аудитора. Что из них будет использовать аудиторская организация, предстоит решать самостоятельно исходя из опыта работы. Формы рабочей документации должны быть универсальными и использоваться при проведении аудита любого предприятия, осуществляющего ВЭД.

Следующий шаг при проведении аудита внешнеэкономической деятельности - изучение условий договоров и сравнение их с паспортами сделок. Аудитор выясняет, какие организации оказывают услуги по транспортировке и сопровождению экспортных, импортных грузов, при этом происходит накопление дополнительной информации о правомерности применения льготы по НДС. В процессе аудита аудитор проверяет экспортные поставки на предмет соблюдения сроков расчетов по поступлению экспортной валютной выручки. Поэтому, если аудитор уверен в добросовестности уполномоченного банка, полнота поступления выручки может проверяться только по отдельно взятым контрактам.

Следующий этап - проверка правильности, полноты, своевременности оприходования выручки, закрытия дебиторской задолженности по ранее отгруженным партиям, своевременного и правильного определения курсовой разницы, возникающей на счетах расчетов. В случае несоответствия аудитор указывает на ошибки и предлагает исправить их до момента подготовки аудиторского заключения.

Проверка этих документов позволяет аудитору обработать сведения для подтверждения данных строки 010 "выручка от реализации продукции работ, услуг" формы № 2 "Отчет о прибылях и убытках".

Для проверки себестоимости реализованной продукции на экспорт аудитору необходима первичная учетная документации по оприходованию и 
списанию сырья и материалов на производство экспортной продукции. Аудитор выясняет глубину разделения аналитического учета производства экспортной продукции и продукции, реализуемой на внешнем рынке. При этом аудитор сталкивается, как правило, с рядом трудностей, поскольку технологические особенности производства.

Операции, осуществляемые в иностранной валюте, относятся к числу наиболее сложных объектов учета, поэтому аудит этих операций целесообразно осуществлять методом сплошного контроля.

По результатам аудита внешнеэкономической деятельности предприятия аудитор получает информацию для заполнения отдельных строк налоговых деклараций, связанных с расчетом налога на прибыль и налога на добавленную стоимость. Эта информация передается коллегам, отвечающим за достоверность счетов 67, 68, 69 по налогам и обязательным платежам в бюджет и во внебюджетные фонды.

Проведение изучения и оценки системы бухгалтерского учета и внутреннего контроля должно осуществляться в соответствии с требованиями Федерального правила (стандарта) “Оценка аудиторских рисков и внутренний контроль”, осуществляемый аудируемым лицом.

Так как экспорт и импорт являются противоположными видами внешнеэкономических операций, то проведение аудита импортных товаров отличается от аудита экспортных товаров. Порядок проведения аудита экспортных и импортных операций будет рассмотрен нами далее.

Из всего спектра аудиторских процедур проверки для аудита импорта наиболее применимыми являются инспектирование и пересчет. Это связано в первую очередь с тем, что практически все документальные аудиторские доказательства имеют фактически смешанный характер (внешняя и внутренняя информация) и применение таких, например, процедур, как запрос и подтверждение, вряд ли оправданно. Учитывая особенности импортных операций, применение процедуры наблюдения также не всегда возможно. Перспективным является применение аналитических процедур. 
Для получения аудиторских доказательств достоверности и законности импортных операций можно выделить три основных направления:

• оценка соответствия операции таможенному законодательству;

• использование результатов банковского контроля;

• $\quad$ использование результатов внутреннего контроля аудируемого лица или непосредственная проверка порядка учета организации по этим операциям.

Проведение процедур получения аудиторских доказательств регламентировано федеральным стандартом "Аудиторские доказательства", а их документирование федеральным стандартом "Документирование аудита". Однако при этом необходимо учитывать также положения и других аудиторских стандартов.

В частности, в федеральном стандарте "Существенность в аудите" отмечается, что наряду с устанавливаемым количественным уровнем существенности, аудитором должна быть учтена возможность и качественных искажений. При этом на существенность могут оказывать влияние нормативные акты РФ, регламентирующие деятельность проверяемого объекта.

Импортные операции как объект аудита можно разделить на импорт материальных и нематериальных ценностей. В основу такого разделения положены различия в их физических свойствах: материальные ценности имеют вещное воплощение, а нематериальные - нет.

При аудите экспортных операций, на основе методов учета себестоимости, выбранных предприятием, проверяется правильность определения себестоимости произведенной, отгруженной и реализованной продукции на экспорт (производственная себестоимость и полная фактическая себестоимость). Особенность проверки состоит в том, что при использовании предприятием метода учета себестоимости продукции в ценах реализации (учетных ценах) в аналитическом учете по счету 45 "Товары отгруженные", возникает необходимость переоценки себестоимости продукции, если условиями контракта предусмотрены особые условия по переходу права собственности и предприятие имеет в балансе остатки по счету 45 "Товары 
отгруженные" (экспорт). В данном случае аудитор должен проверить всю цепочку от условий контракта по этапам отгрузки (учетным партиям) до формирования финансового результата по каждой партии продукции (в периоды резкого колебания курсов валюты это особенно важно). Причем, возникает необходимость делать расчет себестоимости реализованной продукции по наступлению каждого факта оплаты. Переоценка счета 45 "Товары отгруженные" производится исключительно по данным аналитического учета, поскольку в балансе счет 45 может быть отражен только в ценах себестоимости. Следует отметить трудоемкость данного этапа проверки, поскольку для подтверждения достоверности остатков счета 45 требуется провести их последовательный пересчет за весь проверяемый период.

Процедуры проверки, включаемые в программу аудита, зависят от организационной структуры проверяемого субъекта, видов его деятельности и других факторов.

Аудитор прослеживает данные по цепочке: "накладная - приходный документ склада - счет-фактура - отражение в журнале учета полученных счетов-фактур - документ на оплату - отражение в книге покупок". Многие организации игнорируют составление журнала учета полученных счетовфактур, хотя обязательное ведение этого документа предусмотрено ст.169 Налогового кодекса Российской Федерации (НК РФ) и постановлением Правительства Российской Федерации от 2.12.2000 г. N 914. В журнале учета должны быть отмечены все полученные счета-фактуры поставщиков, как оплаченные, так и неоплаченные, а в книге покупок - только оплаченные счетафактуры. Счета-фактуры, не оплаченные к концу отчетного периода, подлежат хранению в неподшитом виде. Именно сумма этих неоплаченных счетовфактур подтверждает на конец отчетного периода кредиторскую задолженность поставщикам и сальдо по счету 19. Таким образом, в случае ведения организацией журнала учета счетов-фактур можно подтвердить величину дебетового оборота по счету 19, а по книге покупок - сумму кредитового оборота по этому счету за проверяемый период. 
По книге покупок проверяется, производятся ли записи по частично оплаченным счетам-фактурам, а также по партиям товаров, полученным от поставщиков, не являющихся плательщиками НДС. По соответствующей графе книги покупок должен быть показан общий дебетовый оборот (оплата) по счетам 60, 76 вне зависимости от того, содержит ли он НДС или нет.

По результатам проведенных выборок аудитор делает выводы и формирует мнение о достоверности финансовой отчетности предприятия, принимает решение о виде аудиторского заключения, которое будет подготовлено для проверяемого предприятия.

При подготовке и принятии решения о виде аудиторского заключения аудитор анализирует результаты проведенного аудита, оценивает их через аудиторские выборки, определяет уровень существенности нарушений, так как именно он является критерием перехода от одного вида аудиторского заключения к другому. Аудитор предупреждает предприятие, выступающее в качестве налогоплательщика, об ответственности за нарушение валютного законодательства (ст.14 Закона "О валютном регулировании и валютном контроле").

\section{5. Заключительный этап аудиторской поверки ВЭД}

Во всех случаях обязательного аудита аудиторские организации должны подготовить и предоставить проверяемому экономическому субъекту письменный отчет по результатам проведения аудита. Аудиторская организация обязана указать в письменном отчете аудитора все связанные с фактами хозяйственной жизни экономического субъекта ошибки и искажения, которые оказывают или могут оказать существенное влияние на достоверность его бухгалтерской отчетности. Кроме того, в письменном отчете аудитора может быть приведена любая информация, касающаяся проведенного аудита и фактов хозяйственной жизни экономического субъекта, которую аудитор сочтет целесообразной. 
Письменная информация аудитора - конфиденциальный документ.

Содержащиеся в нем сведения не подлежат разглашению аудиторской фирмой, ее сотрудниками либо аудитором, работающим самостоятельно, за исключением случаев, прямо предусмотренных федеральными законами Российской Федерации.

Обобщение результатов проведенного аудита наглядно можно представить в виде таблицы 21.

Таблица 21

Обобщение результатов проверки внешнеэкономической деятельности ОАО «Глэдис»

\begin{tabular}{|c|c|c|}
\hline № п/п & Процедуры по проверке & Выявленные нарушения, замечания \\
\hline 1 & $\begin{array}{l}\text { Система внутреннего } \\
\text { контроля }\end{array}$ & $\begin{array}{c}\text { Контрольная среда отсутствует, система внутреннего } \\
\text { контроля направлена лишь на исправление искажений } \\
\text { бухгалтерского учета. Необходимая специфика учета } \\
\text { импорта, экспорта и контроль, касающийся учета } \\
\text { внешнеторговых операций также отсутствует. }\end{array}$ \\
\hline 2 & $\begin{array}{l}\text { Наличие и правильность } \\
\text { оформления контрактов }\end{array}$ & $\begin{array}{c}\text { Внешнеэкономические контракты ООО «Сатурн» с } \\
\text { иностранными контрагентами отвечает необходимым } \\
\text { требованиям }\end{array}$ \\
\hline 3 & $\begin{array}{l}\text { Своевременность } \\
\text { оформления операций по } \\
\text { оприходованию и } \\
\text { списанию товаров }\end{array}$ & $\begin{array}{c}\text { Списание экспортных товаров соответствует правилам } \\
\text { ведения бухгалтерского и налогового учета РФ. А } \\
\text { приобретение импортных товаров отражается } \\
\text { несвоевременно, при этом производится оплата } \\
\text { транспортировки и страхования фактически не учтенных } \\
\text { товаров. Ошибка носит системный характер. Предпосылки } \\
\text { искажения бухгалтерской отчетности. } \\
\end{array}$ \\
\hline 4 & $\begin{array}{l}\text { Проверка правильности } \\
\text { определения таможенной } \\
\text { стоимости }\end{array}$ & $\begin{array}{c}\text { Определение таможенной стоимости противоречит } \\
\text { таможенному законодательству. Ошибка носит системный } \\
\text { характер. Риск применения штрафных санкций со стороны } \\
\text { таможенных органов. }\end{array}$ \\
\hline 5 & $\begin{array}{l}\text { Налогообложение } \\
\text { импортного и } \\
\text { экспортного товара }\end{array}$ & $\begin{array}{c}\text { Организацией не в полной мере уплачены таможенные } \\
\text { платежи. Искажение информации является существенным по } \\
\text { совокупности и несоответствию законодательству. Ошибка } \\
\text { носит системный характер. Риск составления отчетности по } \\
\text { неверным данным. } \\
\end{array}$ \\
\hline 6 & $\begin{array}{l}\text { Проверка реальности } \\
\text { кредиторской и } \\
\text { дебиторской } \\
\text { задолженностей и } \\
\text { расчетов с иностранными } \\
\text { контрагентами }\end{array}$ & $\begin{array}{c}\text { Дебиторская задолженность иностранных покупателей } \\
\text { отсутствует. А кредиторская задолженность по импортным } \\
\text { операциям документально подтверждена. Просроченная } \\
\text { кредиторская задолженность отсутствует. }\end{array}$ \\
\hline 7 & $\begin{array}{l}\text { Проверка полноты и } \\
\text { правильности } \\
\text { оприходования и } \\
\text { списания товара }\end{array}$ & $\begin{array}{c}\text { Учет импорта и экспорта товаров соответствует } \\
\text { необходимым требованиям. }\end{array}$ \\
\hline
\end{tabular}


Аудиторская проверка заканчивается выработкой мнения аудитора о состоянии проверяемого объекта и написания аудиторского заключения. Аудиторское заключение является независимым свидетельством достоверности и объективности финансовой деятельности предприятия. После формирования мнения о результатах проверки аудиторская организация по желанию клиента проводит сопутствующие аудиту услуги.

Далее производится оплата всей проведенной аудиторской организацией работы, если такая процедура предусмотрена договором.

Завершение аудиторской проверки довольно важная процедура, поскольку от того насколько аудиторская фирма и проверяемая организация останутся удовлетворенными результатами проверки, зависит и профессионализм аудиторской организации и перспективы развития и эффективного функционирования фирмы-клиента.

На основе данных проведенной работы было сформировано аудиторское заключение по аудиту внешнеэкономической деятельности ОАО «Глэдис».

\section{Контрольные вопросы}

1. Планирование аудита внешнеэкономической деятельности.

2. Порядок составления письма-обязательства о согласии на проведение аудита внешнеэкономической деятельности.

3. Аудиторский риск и его компоненты при проверке внешнеэкономической деятельности.

4. Изучение и оценка систем бухгалтерского учета и внутреннего контроля в ходе аудита внешнеэкономической деятельности.

5. Принципы документирования аудита внешнеэкономической деятельности.

6. Требования, предъявляемые к содержанию и оформлению рабочей документации аудитора при проверке внешнеэкономической деятельности.

7. Порядок хранения рабочей документации при аудите внешнеэкономической деятельности. 
8. Виды, источники и методы получения аудиторских доказательств при аудите внешнеэкономической деятельности.

9. Использование работы эксперта при проверке внешнеэкономической деятельности.

10.Права и обязанности хозяйствующих субъектов при проведении аудита внешнеэкономической деятельности.

11.Правила проведения аудиторской проверки внешнеэкономической деятельности по поручениям государственных органов.

12.Основные этапы аудиторской проверки внешнеэкономической деятельности.

13.Письмо-обязательство аудиторской организации о согласии на проведение аудита внешнеэкономической деятельности.

14.Договор на оказание аудиторских услуг при проведении аудита внешнеэкономической деятельности.

15.Определение объема проверки.

16.Изучение и оценка структуры системы бухгалтерского учета и системы внутреннего контроля на предприятии, осуществляющем внешнеэкономическую деятельность.

17.Оценка эффективности системы внутреннего контроля при осуществлении внешнеэкономической деятельности.

18.Предварительное планирование аудита внешнеэкономической деятельности. 19.Цели и задачи предварительного планирования аудита внешнеэкономической деятельности.

20. Основные этапы предварительного планирования .

21.Источники информации для предварительного планирования аудита внешнеэкономической деятельности.

22.Методы сбора информации при предварительном планировании аудита внешнеэкономической деятельности.

23.Применение аналитических процедур в процессе предварительного планирования аудита внешнеэкономической деятельности. 
24.Понимание бизнеса клиента, осуществляющего внешнеэкономическую деятельность.

25.Определение обстоятельств, способных повлиять на жизнедеятельность клиента, осуществляющего внешнеэкономическую деятельность.

26.Ознакомление с организацией и функционированием внутреннего аудита на предприятии-импортере или предприятии-экспортере.

27.Оценка возможности проведения аудита внешнеэкономической деятельности и принятие решения.

31.Основные этапы аудиторской проверки.

32.Подготовительная деятельность до начала проведения аудиторской проверки внешнеэкономической деятельности.

33.Понятие уровня существенности и методы его определения при аудите внешнеэкономической деятельности.

34.Аудиторский риск и характеристика его компонентов при аудите внешнеэкономической деятельности.

35.Документирование аудиторской проверки при аудите внешнеэкономической деятельности.

36.Виды, источники и методы получения аудиторских доказательств.

37.Содержание письменной информации аудитора руководству проверяемого экономического субъекта по результатам аудита внешнеэкономической деятельности.

38.Порядок подготовки письменной информации аудитора руководству проверяемого экономического субъекта по результатам аудита внешнеэкономической деятельности.

39.Оформление результатов аудиторской проверки внешнеэкономической деятельности. 


\section{Примеры решения задач}

1. Специалистами аудиторской фирмы «Консул» проводится аудиторская проверка финансово-хозяйственной деятельности ОАО «Альянс» за 2008 год. Разработайте примерный вариант договора на проведение аудиторской проверки.

\section{Решение :}

\section{Договор об оказании аудиторских услуг}

г.Астрахань

"11"января 2009г.

ООО АФ «Консул», именуемое в дальнейшем Аудитор, в лице генерального директора Сапрыкиной Светланы Васильевны, действующего на основании Устава, с одной стороны, и ОАО «Альянс», именуемое в дальнейшем Заказчик, в лице председателя правления, действующего на основании Устава и Положения о правлении, с другой стороны, заключили настоящий договор о нижеследующем.

1. Заказчик поручает, а Аудитор принимает на себя обязательства по даче заключений по финансовым отчетам Заказчика за 2008 год,

2. Срок дачи заключений по финансовым отчетам: 28 февраля 2009 г..

3. Стоимость оказываемых услуг составляет: 300000 (триста тысяч) рублей.

4. Расчеты между сторонами производятся в следующем порядке:

- аванс в размере 150000 (сто пятьдесят тысяч) рублей оплачивается в течение пяти дней со дня заключения настоящего договора;

- 150000 (сто пятьдесят тысяч) рублей оплачивается в течение трех дней со дня подписания акта выполненных работ. 
5. Заказчик обязуется:

- предоставлять Аудитору данные по оперативному бухгалтерскому учету, документы, планы, приказы, а также иную необходимую документацию;

- выделять рабочие места для работников Аудитора, шкаф-сейф для хранения документов;

- обеспечить при необходимости присутствие своих материально ответственных лиц, печатание подготовленных Аудитором документов;

- оплачивать оказываемые услуги в соответствии с условиями настоящего договора.

6. Аудитор обязуется:

- соблюдать правила внутреннего распорядка предприятия Заказчика;

- применять при оказании услуг законные и объективные методы и средства, подкреплять выводы документально;

- не разглашать выявленные в ходе работы или сообщенные ему данные, являющиеся информацией конфиденциального характера или составляющие коммерческую тайну.

7. Особые условия по договору: отсутствуют.

8. За неисполнение или ненадлежащее исполнение своих обязанностей по настоящему договору стороны несут ответственность, предусмотренную действующим законодательством.

9. Споры между сторонами разрешаются путем переговоров.

10. В случае невозможности разрешения споров мирным путем, они разрешаются в порядке, установленном действующим законодательством.

11. Настоящий договор вступает в силу с момента подписания, составлен в двух экземплярах.

12. Юридические адреса сторон.

Аудитора:

Заказчика:

Подписи, печати 


\section{Задачи для самостоятельного решения}

\section{Задача 1.}

Аудиторская фирма «Дина» заключила договор на проведение аудиторской проверки ОАО «Арт» за 2008 год. Составьте письмообязательство и договор на проведение аудита. Подготовьте документы по планированию аудита.

\section{Задача 2.}

Разработайте вариант программы проведения аудиторской проверки расходов ОАО «Карина» и классификатор возможных нарушений по указанному направлению проверки.

\section{Задача 3.}

Составьте варианты положительного, модифицированного аудиторского заключения и отказа от выражения мнения по результатам обязательного аудита, воспользовавшись исходными данными условного предприятия, а также аудиторской фирмы.

\section{Контрольные тесты}

1. Количество территориально обособленных подразделений аудируемого лица и их пространственную удаленность друг от друга оценивается на этапе:

а) оценки аудиторских доказательств, выявленных в ходе проверки и подготовки аудиторского заключения;

б) составления общего плана аудита;

в) подготовки программы аудита;

г) составления общего плана и программы аудита.

2. Аудируемый субъект предъявил претензию аудиторской организации по результатам проверки экспортных операций. Она отклонила претензию, считая, что она должна быть адресована приглашенному со стороны 
эксперту, по вине которого аудиторы не заметили искажение отчетности. Оцените ситуацию.

а) аудиторы правы, это не их ошибка;

б) согласие руководства экономического субъекта на приглашение эксперта для того и необходимо, чтобы оно само определило уровень квалификации эксперта и само решало, стоит ли на него полагаться;

в) использование работы эксперта при проведении аудита, в том числе ссылка на его работу в аудиторском заключении, не снимает ответственности с аудиторской организации;

г) аудиторы не правы, это их ошибка.

3. Рабочую документацию аудитора по результатам проверки внешнеэкономической деятельности рекомендуется хранить:

а) у экономического субъекта вплоть до следующей аудиторской проверки;

б) в папках (файлах) в аудиторской организации не менее пяти лет;

в) место и срок хранения определяет аудиторская организация по согласованию с аудируемым субъектом;

г) не хранится вообще.

4. Назовите одно из нарушений, имеющих место у аудируемого субъекта, занимающегося внешнеэкономической деятельностью, которое ведет к появлению искажений в учете и отчетности, исходя из требований правила (стандарта) РФ "Действия аудитора при выявлении искажений бухгалтерской отчетности":

а) несоблюдение графика документооборота и предоставления внутренней отчетности;

б) отсутствие службы внутреннего контроля у экономического субъекта;

в) отсутствие или несоблюдение учетной политики отражения в учете и отчетности хозяйственных операций и оценки имущества;

г) соблюдение графика документооборота и непредоставления внутренней отчетности. 
5. Необходимо ли готовить письмо-обязательство о согласии на проведение аудита при проведении аудита внешнеэкономической деятельности:

а) по усмотрению аудиторской организации;

б) необходимо, так как по результатам аудита будет выдаваться аудиторское заключение, это требование российских аудиторских правил (стандартов);

в) это правило (стандарт) носит рекомендательный характер, поэтому не обязательно;

г) обязательно. 


\section{Глава 6. Методика аудита внешнеэкономической деятельности}

\section{1. Аудит имущества и обязательств, выраженных в иностранной валюте}

Приступая к проверке внешнеэкономической деятельности, аудитору прежде всего необходимо установить, выполняет ли организация требование Положения по ведению бухгалтерского учета и бухгалтерской отчетности в Российской Федерации и других нормативных документов об обособленном ведении бухгалтерского учета внешнеэкономической деятельности. Для этого в приказе по учетной политике на основе общепринятого плана счетов должны быть отражены счета и субсчета, используемые для внешнеэкономических операций.

Затем аудитор выясняет, как отражаются в учете организации валютные операции. В данном случае нужно исходить из того, что синтетический учет валютных операций должен вестись в рублях, а аналитический- одновременно в двух единицах измерения, в иностранной валюте и в рублях по курсу Банка России на дату совершения бухгалтерской операции.

Целью аудита валютных средств и валютных операций является выражение мнения о достоверности финансовой (бухгалтерской) отчетности и соответствии порядка ведения бухгалтерского учета на предприятии законодательству РФ.

Задачи проверки должны быть направлены на достижение поставленной цели, и конкретизировать вопросы проверки.

Методика аудита учета внешнеэкономических операций по кассе, валютному и прочим счетам в банках должна учитывать следующие задачи [12]:

- Определение цели проверки, источников информации и организации внутреннего контроля.

- Правовая оценка совершенных операций по кассе, валютному и прочим счетам в банках в соответствии с законодательством.

- Аудит бухгалтерского учета операций по кассе, валютному и 
прочим счетам в банках.

- Аудит налогового учета операций по кассе, валютному и прочим счетам в банках.

- Аудит достоверности отражения валютных операций в показателях бухгалтерской (финансовой) отчетности.

Цель аудита валютных операций по кассе, валютному и прочим счетам в банках - состоит в установлении соответствия совершенных по кассе операций в иностранной валюте, по валютным и прочим счетам в банках действующему законодательству и подтвердить достоверность их отражения в бухгалтерском учете [12].

К источникам информации для проведения аудита учета валютных операций по кассе, валютному и прочим счетам в банках относятся:

1. главная книга;

2. журнал - ордер №1;

3. ведомость №1;

4. регистры синтетического и аналитического учета кассовых операций по счету 50;

5. приходные и расходные кассовые ордера;

6. журналы регистрации приходных и расходных кассовых ордеров, выданных доверенностей;

7. кассовая книга;

8. расписка инкассатора о приемке иностранной валюты в кассу банка;

9. журнал учета справок о покупке валюты по форме № 0406007;

10. копии заявки на получение иностранной валюты;

11. отчет об использовании средств в иностранной валюте;

12. авансовые отчеты и журнал регистрации авансовых отчетов;

13. договоры, заключенные с иностранными поставщиками товаров, работ, услуг, результатов интеллектуальной деятельности;

14.паспорт сделки импортера; 
15.счет на оплату от поставщиков;

16.грузовые таможенные декларации/транзитные декларации, подтверждающие выпуск товаров в таможенном режиме «выпуск для внутреннего потребления»;

17.документы, подтверждающие выполнение работ, предоставление услуги и прав на результаты интеллектуальной деятельности при совершении внешнеторговых сделок;

18.банковские документы в виде выписок с валютного, аккредитивного счета, счета корпоративных карточек;

19. регистры синтетического и аналитического учета по счетам учета денежных средств, расчетов с поставщиками и подрядчиками, прочих доходов и расходов.

Задачами аудита валютных средств и валютных операций являются:

- законность открытия валютных счетов;

- соответствие сумм по выпискам банка суммам, указанным в

приложенных к ним первичных бухгалтерских документов;

- проверка полноты и своевременности оприходования валюты;

- проверка правильности определения курсовых разниц;

- проверка правильности бухгалтерского учета курсовых разниц;

- проверка правильности оформления кассовых ордеров на поступление и выдачу валюты.

При проведении аудиторской проверки организации внутреннего контроля по учету операций по кассе проводится прежде всего в целом по кассе, а потом - отдельно по кассовым операциям в иностранной валюте. Поэтому общие контрольные тесты, которые использует аудитор, позволяют выразить общее представление по состоянию внутреннего контроля по учету операций по кассе как в рублях, так и в иностранной валюте [12]. Однако для отражения специфики кассовых операций в иностранной валюте аудитор должен в ходе аудита организации внутреннего контроля по учету кассовых операций получить ответы на вопросы, представленные в анкете (вопроснике). 


\section{Анкета оценки внутреннего контроля по учету кассовых операций}

\begin{tabular}{|c|c|c|c|c|}
\hline \multirow[t]{2}{*}{ Вопрос } & \multicolumn{3}{|c|}{ Ответы } & \multirow[t]{2}{*}{ Примечания } \\
\hline & Да & Нет & $\begin{array}{c}\text { Нет } \\
\text { ответа }\end{array}$ & \\
\hline $\begin{array}{l}\text { На предприятии ведется одна кассовая книга для } \\
\text { учета движения денежных средств в рублях и в } \\
\text { иностранной валюте или отдельные кассовые книги } \\
\text { для учета движения денежных средств в рублях и в } \\
\text { иностранной валюте? }\end{array}$ & & & & \\
\hline $\begin{array}{l}\text { Как осуществляется регистрация приходных и } \\
\text { расходных кассовых ордеров в иностранной валюте? }\end{array}$ & & & & \\
\hline $\begin{array}{l}\text { Кем и как ведется журнал учета справок по } \\
\text { форме № } 0406007 ?\end{array}$ & & & & \\
\hline $\begin{array}{l}\text { Как контролируются сроки нахождения иностранной } \\
\text { валюты в кассе предприятия? }\end{array}$ & & & & \\
\hline $\begin{array}{l}\text { Допускаются ли случаи выдачи иностранной валюты } \\
\text { под отчет из валютной выручки до момента } \\
\text { зачисления выручки на валютный счет организации? }\end{array}$ & & & & \\
\hline $\begin{array}{l}\text { Проверяется ли службой внутреннего контроля } \\
\text { соответствие условий открытия аккредитива в } \\
\text { пользу иностранного поставщика условиям договора } \\
\text { с данным поставщиком? }\end{array}$ & & & & \\
\hline $\begin{array}{llrr}\text { Как проверяется } & \text { службой внутреннего контроля } \\
\text { соответствие } & \text { проведенных } & \text { операций } \\
\text { корпоративному } & \text { банковскому } \\
\text { валютного законодательства? } & & \\
\end{array}$ & & & & \\
\hline $\begin{array}{l}\text { Разработан ли график документооборота по учету } \\
\text { операций по валютному счету и прочим счетам в } \\
\text { банках? }\end{array}$ & & & & \\
\hline $\begin{array}{l}\text { Как контролируется наличие } \text { первичных } \\
\text { документов, подтверждающих движение денежных } \\
\text { средств по корпоративной карте? }\end{array}$ & & & & \\
\hline $\begin{array}{l}\text { Проводится ли ежемесячная проверка правильности } \\
\text { образования на счетах } 52,55 \text { суммы курсовой } \\
\text { разницы? }\end{array}$ & & & & \\
\hline 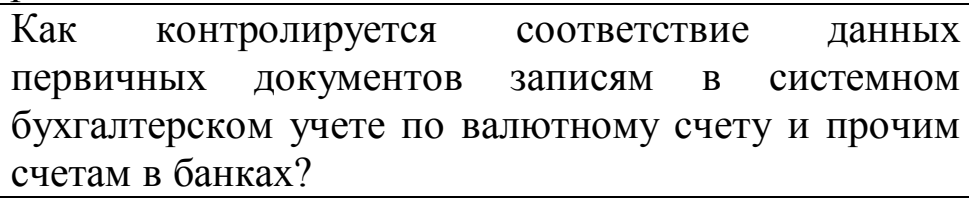 & & & & \\
\hline $\begin{array}{l}\text { Как проводится инвентаризация денежных средств, } \\
\text { находящихся на валютном счете, в аккредитивах, на } \\
\text { счете банковской корпоративной карты? }\end{array}$ & & & & \\
\hline
\end{tabular}

Правовая оценка совершенных операций по кассе, валютному счету и прочим счетам в банках должна основываться на требованиях Федерального закона от 10.12.2003 г. № 173-Ф3 «О валютном регулировании и валютном контроле», допускающего наличные операции в иностранной валюте, 
связанные с расчетами в магазинах беспошлинной торговли, а также с расчетами при реализации товаров и оказании услуг пассажирам в пути следования транспортных средств при международных перевозках.

В ходе аудита валютных операций необходимо установить, как выполняются требования п. 1 ст. 19 Федерального закона РФ № 173-Ф3, который установил, что при осуществлении внешнеторговой деятельности резиденты обязаны в сроки, предусмотренные внешнеторговыми договорами (контрактами), обеспечить:

1) получение от нерезидентов на свои банковские счета в уполномоченных банках иностранной валюты или валюты Российской Федерации, причитающейся в соответствии с условиями указанных договоров (контрактов) за переданные нерезидентам товары, выполненные для них работы, оказанные им услуги, переданные им информацию и результаты интеллектуальной деятельности, в том числе исключительные права на них;

2) возврат в Российскую Федерацию денежных средств, уплаченных нерезидентам за не ввезенные на таможенную территорию РФ (не полученные на таможенной территории РФ) товары, невыполненные работы, неоказанные услуги, непереданные информацию и результаты интеллектуальной деятельности, в том числе исключительные права на них.

При совершении операций с наличной иностранной валютой должны быть выписаны обычные кассовые ордера (приходные или расходные), в которых указана сумма в валюте платежа (например, доллары США, евро и т.п.) и в рублях. Операции в кассовой книге должны быть отражены как в валюте платежа, так и в рублевом эквиваленте по курсу на дату совершения операции.

Особого внимания аудиторов требует проверка операций, проводимых по корпоративным картам.

Осуществляя проверку операций по валютным счетам, аудитор должен помнить, что продажа товаров (работ, услуг) за иностранную валюту на территории РФ запрещена. 
Все операции, связанные с движением иностранной валюты на счетах в уполномоченных банках, отражаются в бухгалтерском учете в двух оценках: в иностранной валюте и в рублях. Сумма в рублях исчисляется по курсу рубля к иностранной валюте, установленному ЦБ РФ на дату совершения операции.

Проверяющему необходимо установить, какой курс используется для пересчета иностранных валют в рубли, руководствуясь при этом ПБУ 3/2006 «Учет активов и обязательств организации, стоимость которых выражена в иностранной валюте».

Курсовые разницы по остаткам средств на валютных счетах исчисляются на дату: составления отчетности; совершения операции по валютному счету; могут исчисляться по мере изменения курсов валют.

Аудитор должен проверить правильность и своевременность расчета курсовых разниц и их отражение на счетах бухгалтерского учета в составе прочих доходов или расходов.

При этом нужно исходить из того, что система бухгалтерского контроля должна выполнять следующие задачи:

1) своевременное исполнение всех контрактных обязательств и условий действующего контракта;

2) своевременные расчеты с банками, инофирмами, бюджетом;

3) строгий контроль за передвижением и сохранностью грузов на всем пути их следования от поставщика к покупателю.

После проверки соответствия выписок банка и приложенных к ним первичных документов аудитор проверяет правильность и полноту отражения операций по валютным счетам в регистрах бухгалтерского учета. Для этого данные выписок банка сверяются с данными журнала-ордера № 2/1 и ведомости № 2/1. Остаток по валютным счетам предприятия на отчетную дату подлежит пересчету с отражением курсовой разницы в составе прочих доходов или расходов. Сальдо по счету 52 «Валютные счета», отражаемое в главной книге, сверяется с данными ведомости № 2/1 и выписки банка на отчетную дату. 
Проверяя валютные операции, аудитор должен знать, что стоимость имущества и обязательства (денежных средств, задолженности, различных товарно-материальных ценностей и др.), выраженная в иностранной валюте, для отражения в бухгалтерском учете подлежит пересчету в рубли по курсу Центрального банка РФ, действовавшему на определенную дату. [16]

Особого внимания требует аудит расчетов с подотчетными лицами по краткосрочным заграничным командировкам.

При аудите расходов по загранкомандировкам необходимо помнить, что все расходы на командировки должны иметь документальное подтверждение. Эти расходы учитываются в составе управленческих расходов, a, следовательно, влияют на показатель прибыли. Расходы, не подтвержденные первичными документами, не принимаются для целей налогообложения прибыли.

В целях налогообложения суточные принимаются в пределах установленных норм. При проверке выплаты суточных необходимо установить:

• $\quad$ день пересечения границы Российской Федерации при выезде в загранкомандировку, так как в этот день суточные оплачиваются в инвалюте;

• день пересечения границы Российской Федерации при возвращении из загранкомандировки, так как в этот день суточные выплачиваются в рублях.

Аудитор должен помнить, что за счет валютных средств, выданных на оплату командировочных расходов, не могут оплачиваться представительские расходы, телефонные разговоры и другие затраты, хотя и связанные с загранкомандировкой, но не входящие в состав командировочных расходов, согласно установленных правил. Организация может возместить такие расходы работнику только в рублях. Возмещение в иностранной валюте расценивается как нецелевое расходование валютных средств, их выплата с валютного счета не предусмотрена.

Представительские расходы могут быть оплачены с использованием 
пластиковых карт, однако, по статье «командировочные расходы» они проходить не должны.

Также не допускается покупка материальных ценностей за счет средств, выданных на оплату командировочных расходов.

Кроме этого аудитор должен установить:

• взимается ли налог на доходы физических лиц, при выплате командированным лицам суточных сверх установленных норм, или когда какие-либо командировочные расходы не подтверждены документально;

• являются ли командированные работники сотрудниками организации, в противном случае проверить, заключены ли с этими работниками договоры на выполнение работ, оказание услуг и правильно ли взимается с них налог на доходы.

Стоит отметить, что на таких же условиях должны совершать поездки за рубеж учредители, не работающие в данной организации.

Аудит расчетов с подотчетными лицами, выезжающими в командировку за границу РФ, целесообразно осуществлять сплошным методом, так как при выполнении этих операций наиболее часто встречаются некорректные действия подотчетных лиц.

Основными документами, которые необходимо подвергнуть изучению при проверке расчетов с подотчетными лицами, выезжающими в командировку за границу, являются:

1. авансовые отчеты с приложенными оправдательными документами;

2. журнал регистрации авансовых отчетов;

3. приказы о направлении сотрудников в загранкомандировку;

4. служебные задания для направления в командировку и отчеты об их выполнении (форма Т-10а);

5. приказы об установлении нормы суточных работникам;

6. сметы представительских расходов и приказы об утверждении смет представительских расходов. 
Признаками отсутствия или недостаточности внутреннего контроля при расчетах с подотчетными лицами, выезжающими в загранкомандировки, являются: несоблюдение установленных сроков предоставления отчетов о полученных суммах; наличие задолженности подотчетных лиц, не погашенной в установленные сроки; списание просроченной задолженности подотчетных лиц по истечении сроков исковой давности на расходы; отсутствие утвержденных руководителем предприятия смет представительских расходов и т.д.

Аудитору необходимо знать особенности учета и использования дорожных чеков, т.е. платежных документов в иностранной валюте.

Аудитором проверяется правильность ведения журнала учета справок формы №04060007. В нем аудитор проверяет указаны ли сумма дорожных чеков, выданная командируемому лицу, дата выдачи ему справки по форме № 0406007. Затем проверяет наличие в гр. 9 журнала должна подпись командируемого лица, подтверждающая получение справки по форме № 0406007. Журнал учета справок по форме № 0406007 оформляется аналогично кассовой книге, т.е. он должен быть пронумерован, прошнурован и скреплен круглой печатью. На последнем листе журнала указывается количество листов, которое заверяется руководителем и главным бухгалтером, и делается оттиск круглой печати. Срок хранения этого журнала — 5 лет с даты окончания его ведения.

Далее аудитором проверяется порядок отражения выдачи валюты и дорожных чеков на командировочные расходы в бухгалтерском учете. Так как дорожные чеки имеют номинал, выраженный в иностранной валюте, их учет должен соответствовать правилам, установленным для бухгалтерского учета валютных операций в ПБУ 3/2006. Оприходование в кассу и выдача дорожных чеков под отчет отражаются в бухгалтерском учете по курсу ЦБ РФ на дату совершения операции. За время нахождения дорожных чеков в кассе либо у подотчетного лица возникает курсовая разница, которая списывается как прочие доходы или расходы. 
Аудитором проверяется срок представления авансовых отчетов после возвращения работника из служебной заграничной командировки, который составляет не более 10 календарных дней. Не позднее 20 календарных дней с даты возвращения из служебной командировки работника организация обязана сдать неизрасходованные иностранную валюту или дорожные чеки в уполномоченный банк и представить ему отчет по соответствующей форме, где содержатся сведения об израсходованных подотчетных суммах. Организация представляет в уполномоченный банк отчет в двух экземплярах. Один экземпляр (оригинал) подшивается в досье «Командировочные расходы», второй (копия) с отметкой банка даты приема оригинала отчета возвращается организации.

Погашение справок № 0406007 уполномоченным банком осуществляется путем проставления соответствующей отметки, заверяется подписью кассира или ответственного исполнителя бухгалтерии по учету валютных операций. После этого справки помещаются в досье «Командировочные расходы».

Если отчет не представлен в уполномоченный банк в течение 3 месяцев после даты, предусмотренной в гр. 12 заявки клиента, а ожидаемая сумма отчета превышает 5 тыс. долл., то банк в течение 5 дней обязан известить об этом Министерство финансов РФ.

Аудитор должен проверить документы, приложенные к авансовому отчету. К возмещению за время нахождения работника в загранкомандировке принимаются суточные, расходы по проезду до пункта отправления, включая расходы по провозу багажа, по найму жилого помещения, на получение заграничного паспорта и виз, за прописку паспорта, комиссионные, удержанные при обмене чека на иностранную валюту. Кроме того, аудитор проверяет правильность удержания налога на доходы физических лиц с сумм суточных, выплаченных сверх установленных законодательством норм.

Необходимо установить случаи перерасхода подотчетных авансовых сумм, подтвержденных документально. В этом случае сумма задолженности работнику может погашаться либо путем выдачи суммы задолженности 
наличной иностранной валюты, либо путем выдачи эквивалентной суммы задолженности в рублях, либо путем перевода средств в иностранной валюте с текущего валютного счета организации на валютный счет командируемого лица.

Неиспользованная наличная иностранная валюта или дорожные чеки вносятся в кассу командируемым лицом. Это может быть сделано следующими способами:

• внести в кассу неиспользованные дорожные чеки;

- внести в кассу наличную иностранную валюту в сумме неиспользованных дорожных чеков;

- погасить сумму задолженности иной наличной иностранной валютой, чем валюта полученных дорожных чеков, если курс рубля к данной иностранной валюте устанавливается ЦБ РФ;

- сочетать в любом соотношении три указанных выше варианта.

Аудитор должен проверить, производится ли пересчет по курсу ЦБ задолженности подотчетных лиц на дату утверждения представленного авансового отчета по расходам на загранкомандировку. Курсовая разница отражается в общем порядке в составе прочих доходов или расходов.

Во время пребывания за границей у представителей организации могут возникать расходы, связанные с их целевой коммерческой деятельностью. Это расходы по проведению официальных приемов представителей других фирм, посещению выставок, культурно-зрелищных мероприятий и т.д. Оплата таких расходов возможна по валютной пластиковой карте с последующим оформлением авансового отчета.

При использовании пластиковых карт для оплаты в загранкомандировках представительских расходов аудитор обращает внимание на наличие и правильность оформления следующих документов:

• приказа о направлении сотрудника в загранкомандировку с указанием фирм и их представителей, с которыми запланированы встречи, даты и места проведения встреч; 
- сметы представительских расходов;

- $\quad$ актов проведения мероприятий с приложением оправдательных первичных документов (прилагаются к отчету о командировке).

Аудитор выявляет случаи покупки командированным лицом за границей товаров с использованием пластиковой карточки. Валютные операции по счетам пластиковых карт осуществляются в соответствии с требованиями валютного законодательства, отражение в бухгалтерском учете таких операций производится с учетом требований ПБУ 3/2006. Учет операций по счетам пластиковых карт осуществляется на счете 55 «Специальные счета в банках». Приобретенные за границей РФ с применением пластиковых карт ценности должны быть соответствующим образом оформлены. Для их оприходования необходимы таможенная декларация, документ об оплате НДС, таможенных пошлин и сборов.

Держателями корпоративной пластиковой карты являются один или несколько сотрудников организации. Число держателей карты согласуется между руководством организации и обслуживающим банком. Аудитору необходимо проверить отчеты по израсходованным средствам, так как средства, списанные с карточного счета, считаются выданными под отчет. Расчетными документами, сопровождающими сделку по пластиковой карточке, являются чеки, свидетельствующие о расходах по карте, подтвержденные квитанциями, товарными чеками на получение соответствующих услуг. Аудитор обязан проверить на конец каждого месяца переоценку валютного остатка по карточному счету.

Далее, аудитор проверяет правильность и полноту отражения операций по расчетам с подотчетными лицами в регистрах бухгалтерского учета. Для этого данные авансовых отчетов сверяются с данными журнала-ордера № 7. Остаток дебиторской задолженности подотчетных лиц, выраженной в иностранной валюте, на отчетную дату подлежит пересчету с отражением курсовой разницы в составе прочих доходов или расходов. 


\section{2. Методика аудита соблюдения организациями-экспортерами правил ведения бухгалтерского учета}

Существующие в настоящее время методики проведения аудита бухгалтерской отчетности, как отечественные, так и зарубежные, являются универсальными, не учитывающими отраслевые особенности проверяемых организаций. При этом необходимость разработки методики аудита бухгалтерской отчетности экспортеров, отражающей особенности выполняемых ими хозяйственных операций, вызвана существованием различий в подцелях аудита, видах и характере хозяйственных операций, в степени влияния отдельных статей бухгалтерской отчетности на ее достоверность.

При аудите бухгалтерской отчетности экспортеров необходимо определить специальные подцели аудита. К ним относятся:

1. Проверка достоверности финансового результата деятельности по экспорту продукции.

2. Подтверждение достоверности сумм дебиторской и кредиторской задолженности покупателей экспортируемой продукции.

3. Проверка достоверности формирования себестоимости экспортируемой продукции.

4. Проверка достоверности отражения в учете операций с иностранной валютой.

5. Проверка достоверности величины налоговых обязательств.

Кроме этого, аудитор должен руководствоваться общими критериями правильности статей бухгалтерской отчетности: существованием, возникновение, права и обязательства, полнота, оценка, точность, представление и раскрытие.

Аудит отчетности начинается с процесса группировки ее показателей, который называется процессом дезагрегации (от отчетности к хозяйственной операции). Процесс дезагрегации отражает дедуктивный подход и включает 
следующие этапы:

1. Разделение бухгалтерской отчетности на статьи.

2. Определение структуры каждой статьи и установление взаимосвязи между ее статьями и соответствующими счетами бухгалтерского учета.

3. Разделение информации, отраженной на счетах бухгалтерского учета, на хозяйственные операции.

На первом этапе дезагрегации определяется степень важности различных критериев для статей бухгалтерской отчетности. При этом устанавливается степень важности различных критериев правильности бухгалтерской отчетности: права и обязательства, полнота, точность, существование и возникновение, представление и раскрытие, оценка.

На втором этапе для статей бухгалтерского баланса определяются счета, сальдо которых включены в конкретные статьи. Для показателей отчета о прибылях и убытках устанавливается взаимосвязь со счетами, обороты по которым участвовали в формировании соответствующих показателей. На данном этапе аудитор уже может получить доказательства соответствия бухгалтерской отчетности критериям полноты, установив полноту перенесения сальдо и оборотов по счетам в отчетность.

На третьем этапе дезагрегации аудитор устанавливает степень достоверности бухгалтерской отчетности на основе информации о хозяйственных операциях, отраженной на счетах бухгалтерского учета.

Существует также другой метод аудита достоверности бухгалтерской отчетности, суть которого состоит в проверке «от хозяйственной операции к показателям отчетности» (индуктивный метод). Данный метод состоит из следующих этапов:

1. Проверка конкретных хозяйственных операций.

2. Проверка правильности формирования регистров бухгалтерского учета.

3. Проверка формирования показателей отчетности на основе соответствующих регистров бухгалтерского учета. 
В основе данного метода лежит проверка хозяйственных операций в пределах каждого счета, по которому в проверяемом периоде были обороты. При этом проверяется правильность перенесения и группировки хозяйственных операций в регистры бухгалтерского учета. Затем проверяется правильность формирования показателей бухгалтерской отчетности на основе перенесенных в отчетность данных из соответствующих регистров или оборотов по соответствующим счетам бухгалтерского учета.

Используя метод дезагрегации, аудитор применяет так называемый дедуктивный подход, позволяющий сконцентрировать внимание на конкретном результирующем показателе отчетности. Однако, такая проверка допускает исключение из числа всех хозяйственных операций организации тех операций, которые по тем или иным причинам не были учтены при формировании показателей отчетности. При индуктивном методе аудитор может проследить логическую цепочку формирования показателей отчетности, однако не обеспечивается оптимальный выбор сегментов аудита, на которые необходимо обратить особое внимание, и который возможен при предварительном анализе.

Методика аудита бухгалтерской отчетности экспортеров должна учесть и индуктивный и дедуктивный подходы, совокупность которых позволит получить наиболее полное представление о составляющих отчетности, повысить эффективность проверки и учесть специфику деятельности экспортеров.

Этапы аудита экспортеров:

1. Общий обзор бухгалтерской отчетности.

2. Комплексный обзор отчетности и оборотно-сальдовой ведомости по счетам бухгалтерского учета.

3. Дезагрегация показателей отчетности на счетах бухгалтерского учета.

4. Определение циклов хозяйственных операций, подлежащих проверке.

5. Проверка правильности отражения в учете хозяйственных операций.

6. Проверка правильности группировки данных бухгалтерского учета в учетных регистрах. 
7. Проверка правильности формирования показателей отчетности на основании данных регистров учета.

На первом этапе аудитор составляет формальное впечатление о проверяемой организации и проверяет отчетность на предмет явно выраженных нарушений. Кроме того, здесь же аудитор анализирует динамику изменения показателей отчетности с целью выявления необычных отклонений или резких изменений. Такой анализ позволяет наметить сегменты аудита, которым необходимо уделить в ходе проверки особое внимание.

На втором этапе аудитор анализирует как бухгалтерскую отчетность, так и оборотно-сальдовую ведомость по всем используемым в отчетном периоде счетам с целью выявления участков учета, на формирование которых в большей степени оказывает специфика деятельности клиента. Проведение анализа оборотно-сальдовой ведомости по всем используемым счетам необходимо из-за того, что в отчетности, в основном, отражаются итоговые данные по ним по состоянию на конец отчетного периода, не учитывая и не отражая обороты по счетам. Анализируя же бухгалтерскую отчетность аудитор не может получить полное представление о характере, объеме и степени значимости осуществляемых клиентом в отчетном периоде операций. Результаты проведения второго этапа позволяют выявить сегменты аудита на формирование которых в большей степени оказывает влияние специфика экспортной деятельности.

Результаты комплексного обзора отчетности и оборотно-сальдовой ведомости по счетам бухгалтерского учета можно оформить рабочим документом «Сегменты аудита, на формирование которых оказывает влияние специфика экспортной деятельности».

Таблица 23

Рабочий документ №

«Сегменты аудита, на формирование которых оказывает влияние специфика экспортной деятельности»

\begin{tabular}{|c|c|c|}
\hline$№$ п/п & Сегменты аудита & Комментарии \\
\hline & & \\
\hline
\end{tabular}


На третьем этапе необходимо провести дезагрегацию выявленных сегментов на счетах бухгалтерского учета.

В ходе осуществления четвертого этапа определяются циклы хозяйственных операций клиента, в пределах которых будет осуществляться проверка.

В настоящее время выделяют циклический и пообъектный подходы к проведению проверки. При пообъектном подходе выделяемые сегменты аудита фактически совпадают с объектами бухгалтерского учета и хозяйственные операции тестируются с точки зрения обособленного получения доказательств по отдельным счетам. Однако, при данном подходе происходит дублирование действий проверяющих, нерациональность и сложность обмена информацией между ними.

В основе циклического подхода лежит выделение в качестве сегментов аудита циклов взаимосвязанных операций. Осуществляя аудит экспортеров, наиболее целесообразно применять именно циклический подход, выделяя следующие циклы:

1. Цикл формирования себестоимости экспортной продукции.

Составной частью цикла являются операции по приобретению товаров, стоимость которых включается в себестоимость экспортной продукции, операции по списанию на себестоимость продукции ТМЦ, операции по калькулированию себестоимости, включение в себестоимость общепроизводственных и общехозяйственных расходов, а также операции, связанные с формированием дебета сч. 19.

2. Цикл продаж продукции на экспорт.

Составной частью данного цикла являются операции по реализации продукции, формированию финансового результата от реализации экспортируемой продукции, операции по отражению в учете выручки от продаж, дебиторской задолженности, авансов, полученных от иностранных контрагентов.

3. Цикл расчетов с бюджетом по НДС. 
Определение сумм НДС, подлежащих предъявлению к вычету по экспортным операциям осуществляется косвенным путем, и прямо не связано с фактическими затратами на производство экспортируемой продукции. Поэтому данный цикл не совмещен с циклом 1, а выделен как отдельный сегмент аудита, в рамках которого подлежат проверке операции по предъявлению к вычету сумм налога, уплаченного по товарам, работам, услугам, используемым при производстве экспортируемой продукции, операциям по начислению НДС с авансов, полученных в счет предстоящих поставок продукции на экспорт, операций по начислению НДС в случае просрочки представления в налоговые органы документов, подтверждающих обоснованность применения нулевой налоговой ставки.

4. Цикл операций по валютным счетам.

Несмотря на то, что данный цикл тесно связан с циклом реализации и его необходимо выделить в отдельный цикл из-за особенностей бухгалтерского учета и нормативного регулирования операций, проводимых по валютным счетам организации. В рамках данного цикла проверяются операции по получению, реализации и использованию валютной выручки, расчету курсовых разниц.

На пятом этапе проверяют правильность отражения в учете хозяйственных операций, обоснованность, полноту, точность, своевременность отражения хозяйственных операций, соблюдения порядка ведения бухгалтерского учета хозяйственных операций. На данном этапе анализируется первичная документация, являющаяся основанием для отражения операции на счетах бухгалтерского учета, записи на счетах бухгалтерского учета.

В ходе осуществления шестого этапа аудитор осуществляет проверку правильности группировки данных бухгалтерского учета в регистрах учета. Аудитору необходимо проверить правильность, обоснованность, своевременность, полноту и точность отражения в регистрах данных соответствующих первичных документов.

На седьмом этапе осуществляется проверка правильности формирования 
показателей бухгалтерской отчетности на основании проверенных регистров учета. На этом этапе аудитором формируется окончательное мнение о совокупном искажении отчетности и об искажении каждого его показателя.

После осуществления семи этапов аудитор формирует мнение о достоверности бухгалтерской отчетности экспортера составляя аудиторское заключение по результатам проверки.

\section{3. Особенности аудиторских доказательств достоверности}

\section{импортных операций}

Исходя из особенностей внешнеэкономической деятельности, при проверке необходимо установить:

- права предприятия на осуществление ВЭД;

- соответствие сведений, указанных в паспорте сделки, условиям контракта; правильность данных, указанных в грузовой таможенной декларации;

• правильность определения полной импортной стоимости товара.3 Она складывается из его контрактной цены и накладных расходов по товару, оплаченных в иностранной валюте и рублях. К накладным расходам в инвалюте относятся: перевозка, перевалка, страхование груза, хранение на складах, естественная убыль в пределах норм, брокерские и комиссионные расходы (за границей; в таможне РФ), таможенные сборы в инвалюте. К накладным расходам в рублях относятся: перевозка, перевалка, хранение, естественная убыль в пределах норм, пошлины, акцизы, НДС и таможенные сборы в рублях. Таможенная стоимость товара включает в себя контрактную стоимость товара и накладные расходы в инвалюте, оплаченные за границей;

- правильность определения облагаемой базы по уплате НДС на таможне РФ. Облагаемая база слагается из таможенной стоимости товара, таможенной пошлины и акциза по товару;

- правильность оформления операций по импорту товаров (услуг) через посредника. В этом случае с посредником заключается договор комиссии. 
Комиссионное вознаграждение посредника устанавливается либо в виде определенного процента от импортной или внутренней рыночной стоимости товара, либо в виде разницы между рыночной и импортной стоимостью товара. Накладные расходы в рублях и НДС с таможенной стоимости товара оплачивает само предприятие-импортер либо посредник с последующим возмещением этих затрат предприятием-импортером;

- правильность оформления операций по реализации импортных товаров с консигнационных складов России. Иностранная фирма-экспортер может продавать товары через консигнационные склады России. В этом случае фирма заключает договор комиссию с консигнационным складом. В договоре обычно устанавливается определенный срок реализации товара, определенная цена реализации за иностранную валюту, а иногда и за рубли, комиссионное вознаграждение консигнатора (склада) в виде определенного процента от валютной или рублевой выручки за товар или в виде разницы (или части разницы) между договорной ценой по договору комиссии и ценой, по которой консигнатор сможет реализовать товар. Возможны несколько вариантов реализации импортного товара с консигнационного склада;

- правильность оформления операций по импорту за счет централизованных валютных и кредитных ресурсов. Иностранные правительства, ранее получившие государственные кредиты, погашают свою задолженность поставками импортных товаров. Поставки импортных товаров (кроме кредитных закупок) могут осуществляться за счет централизованных валютных средств, т.е. наличной иностранной валютой, выделяемой Минфином РФ в соответствии с решениями Правительства РФ.

Записи операций на валютных счетах ведут в валюте платежа и ее рублевом эквиваленте, действующем на дату поступления средств.

При проведении аудита операций на валютных счетах необходимо установить:

\footnotetext{
• законность открытия валютных счетов;

- $\quad$ соответствие сумм по выпискам банка суммам, указанным в
} 
приложенных к ним первичных документах;

- правильность применения формы расчетов при внешнеэкономической деятельности.

Проверка по счетам расчетов должна осуществляться по следующим основным направлениям:

- проверка наличия и правильности оформления документов, определяющих права и обязанности сторон по поставке материальных ценностей (работ, услуг);

• проверка правильности оплаты или получения сумм за полученные или отгруженные материальные ценности;

- проверка полноты оприходования и списания полученных ценностей.

Особенности расчетов с поставщиками в иностранной валюте. Синтетический учет расчетов с поставщиками в СКВ ведется обычным порядком. Аналитический учет ведется по каждому поставщику раздельно в валюте платежа (долларах США, евро и т.д.) и ее рублевом эквиваленте по курсу Центробанка РФ на дату возникновения обязательств.

При проверке следует обратить внимание на следующее:

- наличие договоров на поставку продукции (выполнение работ, услуг) и правильность их оформления;

- установление даты возникновения и причин образования дебиторской и кредиторской задолженности(при их наличии);

- наличие задолженности с истекшим сроком исковой давности, меры к ее взысканию;

• наличие ценностей, на которые не получены расчетные документы (неотфактурованные поставки). Необходимо проверить, не числятся ли эти поступившие ценности как оплаченные, но находящиеся в пути или не вывезенные со складов поставщиков, и не числится ли стоимость этих ценностей как дебиторская задолженность;

- проведение инвентаризации расчетов. 
Необходимо проанализировать ее результаты, а может быть - провести встречную проверку расчетов;

- проверка полноты оприходования материальных ценностей. Следует сопоставить данные об их количестве и стоимости по платежным документам с данными документов на их оприходование (счетов, товарнотранспортных накладных) и показателями аналитического учета расчетов с поставщиками, книгами складского учета, отчетов движения продуктов и материалов;

- проверка правильности установления цен на материальные ценности. Следует убедиться, что они соответствуют ценам, указанным в договорах поставки;

- проверка правильности списания затрат с кредита расчетов с дебиторами и кредиторами на себестоимость продукции (работ, услуг);

- $\quad$ проверка того, предъявлялись ли штрафные санкции поставщикам при нарушении договорных обязательств;

- проверка правильности списания задолженности с истекшим сроком исковой давности;

- проверка того, предъявлялись ли претензии поставщикам и подрядчикам в случае несоответствия цен и тарифов, обусловленных договорами, а также при выявлении арифметических ошибок в счетах; при обнаружении несоответствия качества стандартам или техническим условиям; за недостачу груза в пути сверх норм естественной убыли; за брак и простои, возникшие по вине поставщиков или подрядчиков;

- $\quad$ проверка того (при проверке расчетов с подрядчиками), обеспечены ли объекты источником финансирования; имеется ли проектно-сметная документация на строящиеся объекты; нет ли приписок объемов выполненных работ (при необходимости провести контрольный обмер выполненных работ);

- проверка правильности ведения аналитического и синтетического учета по счетам 60 “Расчеты с дебиторами и кредиторами”. Провести соответствие данных журналов-ордеров по этим счетам данным, указанным в 
главной книге и балансе;

- проверка правильности составления бухгалтерских проводок по счетам расчетов.

В ряде случаев аудит связан с изучением большого потока документации и бухгалтерских записей. Поэтому проверка документов и записей в учетных регистрах не может быть сплошной. В практической работе аудиторы используют различные варианты выборочной проверки документов:

• проверка части документов за изучаемый период;

• проверка однородных операций за несколько месяцев, за последний месяц каждого квартала, за последний квартал или даже за последние два месяца.

Каждая хозяйственная операция оформляется соответствующими документами. Ими же обосновываются записи в регистрах синтетического и аналитического учета. На основе регистров бухгалтерского учета составляются бухгалтерский баланс и отчетность. Поэтому аудиторы для оценки достоверности совершенных хозяйственных операций прежде всего прибегают к использованию методических приемов проверки документов и записей в регистрах бухгалтерского учета.

В зависимости от содержания контроля и состояния бухгалтерского учета используются различные методические приемы проверки документов. Среди них следует выделить формальную, арифметическую, экспертную, логическую, экономическую, нормативно-правовую, встречную проверку, контрольное сличение, обратный счет, оценку документов по данным корреспондирующих счетов, аналитическую (счетную) проверку отчетности и балансов, сравнение и др. методические приемы проверки документов.

\section{4. Основные направления аудита импортных операций}

При проведения аудита импортных операций важное значение имеет проверка правильности формирования стоимости импортных товаров (оборудования), а именно той стоимости, по которой они будут отражаться в 
учете. При этом необходимо обратить внимание на следующие факторы:

А) дата перехода права собственности, определяемая импортными контрактами.

Несовпадение даты перехода права собственности на приобретаемые материальные ценности и даты оприходования ценностей на склад импортера может оказать непосредственное влияние на искажение величины фактической себестоимости импортных ценностей, что должно учитываться при аудите в качестве факторов аудиторского риска;

Б) порядок включения в фактическую себестоимость приобретаемых импортных ценностей таможенных пошлин и сборов за таможенное оформление.

Если предприятие учитывает уплаченные сборы и пошлины обезличенно, без отнесения на конкретные виды ценностей, то это приводит к искажениям данных бухгалтерского учета и $к$ ошибочным расчетам фактической себестоимости ввезенного имущества и величине налоговых платежей;

В) виды расходов и порядок их отражения в момент таможенного оформления;

Г) порядок пересчета стоимости импортных ценностей в валюту РФ;

Таким образом, порядок формирования фактической себестоимости импортных материальных ценностей должен тщательно оцениваться аудитором с целью формирования мнения о соблюдении законодательства, полноты формирования затрат, своевременности отражения в учете и отчетности импортного имущества.

Для достижения целей аудита необходимо детально исследовать этапы формирования фактической себестоимости импортного имущества. Практика аудита порядка учета импортных ценностей свидетельствует о том, что распространенной ошибкой является неправильное определение даты оприходования поступившего имущества, а значит и курса, по которому следует пересчитать контрактную стоимость ввозимых ценностей, выраженную в иностранной валюте. 
Внимание аудитора следует обратить на то, что отсутствие первичных документов при оформлении импортной операции влечет не только налоговые штрафы за неправильное ведение учета, но и приводит к существенным изменениям в балансе предприятия и достоверность определения налоговой базы. Например, несвоевременное принятие имущества к учету может повлиять на величину налога на имущество, если это произошло не внутри налогового периода.

Подтверждая факт совершения внешнеторговой сделки, аудитор должен рассмотреть следующие первичные документы:

- акцептованные счета поставщиков с приложением спецификаций, квитанций грузового железнодорожного сообщения, коносаментов, авианакладных;

- почтовые квитанции, свидетельствующие об отправке товаров в порты или на склады;

- акты приемки, подтверждающие поступление товаров в порты или на склады;

- коммерческие акты, свидетельствующие о недостачах, излишках, порче товаров;

- акты приемки иностранных экспедиторов, консигнаторов, подтверждающие движение товаров за границей и т.п..

При проведении аудита импортных операций распространенной является ситуация, когда договор не содержит условий определения момента перехода права собственности по сделке, но при этом есть ссылка на международные правила по унифицированному толкованию торговых терминов (ИНКОТЕРМС 90/2000). При заключении такого рода контракта необходимо обратить внимание на то, что в зависимости от условий поставки дата приобретения покупателем права собственности на имущество и дата передачи имущества покупателю различаются.

Следующим этапом программы аудиторской проверки оприходования в учете импортных ценностей является достоверность определения таможенной 
стоимости ценностей. Основополагающим первичным документом для определения стоимости в данном случае является государственная таможенная декларация. Целью проверки исчисления таможенной стоимости является подтверждение того, что:

- избранный метод расчета таможенной стоимости объективен и реален;

-таможенные платежи правильно рассчитаны и включены в себестоимость импортной ценности и в полном объеме перечислены таможенным органам.

Аудитор должен обратить внимание на то, что в основе расчета таможенных платежей лежит таможенная стоимость импортного товара.

Таможенные платежи могут быть перечислены до принятия или одновременно с принятием декларации как в рублях, так и в иностранных валютах по курсу ЦБ РФ. Если по решению таможенных органов импортеру была предоставлена отсрочка или рассрочка уплаты таможенных пошлин и налогов, относящихся к ввозимым ценностям, то этот срок не превышает двух месяцев со дня принятия таможенной декларации. Если в течение срока оформления декларации менялся курс валюты контракта на импорт, то в декларацию должны вноситься изменения, а также необходимо пересчитывать и доплачивает таможенные платежи. Суммы излишне уплаченных таможенных платежей подлежат возврату по требованию декларанта в течение одного года с момента их уплаты или взыскания.

Необходимо обратить внимание на то, что если декларантом выступает таможенный брокер, то он может осуществлять таможенные платежи за импортера - своего клиента. Аудитору же необходимо удостовериться, что таможенный брокер имеет соответствующую лицензию ФТС РФ и договор с клиентом заверен нотариально. Иначе расходы, произведенные брокером, не могут быть включены импортером в стоимость импортного имущества и соответственно нет основания для принятия импортером к зачету уплаченного при таможенном оформлении НДС. Если таможенный брокер возвращает импортеру излишне уплаченные за него платежи, то этот возврат может 
производиться только в рублях.

Еще одним элементом таможенных платежей являются сборы за таможенное оформление (см. таблицу 3 главы 2 данного пособия). Суммы сборов составляют $0,15 \%$ от таможенной стоимости, при этом $0,1 \%$ взимается в рублях, а $0,05 \%$ - в иностранной валюте по курсу ЦБ РФ. Помимо вышеуказанного сбора импортер может уплачивать сборы за хранение и сопровождение груза, что должен учитывать аудитор при проверке данного этапа сделки.

В процессе аудита следует проверить соответствие порядка определения отпускной цены и НДС на предприятиях, приобретающих импортное имущество для дальнейшей реализации. Необходимо обратить внимание на особенности определения налоговой базы при реализации импортного имущества, освобожденного от уплаты НДС на таможне.

При проведении аудита затрат, связанных с оформлением импортных материальных ценностей, аудитор должен удостовериться в правильности расчета курсовых разниц, возникающих при переоценке активов, выраженных в иностранной валюте, а также при отражении операций по покупке валюты для оплаты импортного контракта. При проведении проверки в зависимости от проверяемого периода аудитор должен руководствоваться ПБУ 3/2000 .

Так как основным моментом при импорте материальных ценностей является дата перехода прав собственности, то аудитору целесообразно рассмотреть порядок формирования курсовой разницы в учете импортера в зависимости от условий контракта. При определении достоверности отражения импортных операций в учете аудитор должен констатировать факт правильного применения валютного курса на дату перехода права собственности.

В случае осуществления полной предоплаты для формирования мнения о достоверности отражения курсовых разниц аудитор должен убедиться, что переоценка на счете 76 была произведена на дату совершения операции, на последнюю дату месяца, в котором выдан аванс, или на момент перехода права собственности и, соответственно, зачета выплаченного аванса. Применение 
валютного курса на другие даты приведет к искажению отчетности и неправильному формированию финансового результата. Проверяя соблюдение правил бухгалтерского учета аудитор должен удостовериться, что ежемесячно сумма курсовых разниц отражается на счете 99, участвуя в формировании финансового результата от операции.

Проводя аудиторскую проверку операций по учету курсовых разниц, аудитор должен убедиться в отражении особенностей их учета в учетной политики импортера. Кроме того, целесообразно рассмотреть порядок проведения аудита операций по покупке валюты с точки зрения соответствия их валютному законодательству, полноты и достоверности в бухгалтерском учете импортера.

При проведении проверки операций купли-продажи инвалюты аудитор должен рассмотреть вопросы учета и налогообложения курсовых разниц и отражение затрат на оплату комиссии банка.

Одним из ключевых моментов аудита импортных операций является проверка полноты и правильности отражения в учете операций с импортными ценностями. На данном этапе основополагающим является контроль за определением первоначальной стоимости, по которой ТМЦ будут отражаться в учете. Здесь аудитор должен ознакомиться с положением об учетной политике импортера и выяснить порядок учета поступивших ТМЦ.

Особое внимание в ходе проверки аудитор должен уделить правильности ведения аналитического учета импортных товаров. При проверке правильности формирования фактической стоимости товара одним из основных моментов является определение:

1. Своевременности отражения импортного товара и затрат по его приобретению на счетах.

2. П Полноты затрат, включаемых в фактическую стоимость товара.

3. Обоснованность включенных в стоимость затрат.

Для этого аудитор должен обратить внимание на момент перехода прав 
собственности в соответствии с внешнеторговым контрактом и на момент отражения его стоимости на счетах учета материальных ресурсов. Кроме того, нужно убедиться в том, что на счете 41 числятся только те товары, по которым полностью сформирована фактическая стоимость. Проверяя обоснованность включения затрат, аудитор должен проанализировать состав затрат, включенных в стоимость импортных товаров. При оценке корректности отражения в учете импортной операции необходимо проверить корреспонденцию счетов и соответствие порядка учета принятой на предприятии учетной политике.

Отдельным этапом является оценка достоверности отражения в учете импортного оборудования. Для выражения мнения о достоверности, правильности исчисления налогооблагаемой базы необходимо определить момент перехода права собственности и достоверность определения таможенной стоимости.

Следующий аспект аудиторской проверки, имеющий важное значение для достоверного формирования затрат - это порядок исчисления таможенных платежей, включаемых в стоимость ввозимого товара.

Аудитор должен учесть факторы, влияющие на формирование фактической стоимости импортных ценностей :

1. Метод определения таможенной стоимости.

2. Дату перехода прав собственности.

3. Особенности таможенных режимов, определяющих характер расходов при таможенном оформлении.

4. Порядок пересчета стоимости импортных ценностей, выраженной в валюте, в рубли.

5. Порядок осуществления и отражения в учете транспортных расходов, возмещаемых и прочих расходов по импорту.

При аудите импортных нематериальных ценностей аудитор должен учитывать риски искажения бухгалтерской и налоговой отчетности. Во внимание принимаются не только особенности валютного регулирования и 
контроля, с которыми на разных этапах сталкиваются все участники сделки, но и учитывать особенности налогообложения с применением норм международного права. Для выражения мнения о полноте и достоверности проведенной импортной операции аудитор должен определить особенность импорта услуг, а именно:

- статус иностранного юридического лица;

- местонахождение источника дохода нерезидента;

- предварительное освобождение от налогообложения;

- особенности налогообложения согласно международным конвенциям.

При этом российские аудиторы не имеют права самостоятельно определять статус иностранной организации для целей налогообложения исходя из характера конкретной сделки. Под статусом понимается, обязана ли иностранная организация самостоятельно платить налоги в РФ. Аудитор должен убедиться, что помимо первичных документов у иностранной организации есть нотариально заверенная копия (или оригинал) свидетельства о постановке на учет в налоговых органах, оформленная не ранее предшествующего налогового периода.

Необходимо помнить, что если нерезидент не состоит на налоговом учете в РФ, то это вовсе не означает, что он полностью освобожден от уплаты налогов. Аудитор должен уделить особое внимание операциям, связанным с оказанием услуг и проведением работ иностранным контрагентом отечественному предприятию. При этом сплошной проверке должны подлежать все сделки, не подлежащие обложению налогами у источника выплаты, на предмет наличия на российском предприятии документального обоснования того, что оказание услуг или выполнение работ не приводит к образованию постоянного представительства в РФ.

Следующей особенностью является порядок расчета и удержания НДС у нерезидента. При проведении проверки операций по импорту аудитор должен руководствоваться прежде всего нормами международного права и только затем нормами российского законодательства. При аудите импорта услуг 
аудитор должен знать, заключено ли соглашение об избежании двойного налогообложения со страной экспортера. Но эти соглашения не распространяются на косвенные налоги, например НДС.

Проводя анализ первичных документов аудитор должен убедиться в том, что одновременно с оформлением платежных документов на перечисление оплаты иностранному партнеру был составлен счет-фактура в 2-х экземплярах с указанием полной суммы оплаты иностранной фирме, где отдельной строкой выделяется НДС и делается пометка «Уплата за иностранного поставщиканерезидента».

Рассматривая специфику аудита импорта работ и услуг аудитор должен обратить внимание на ответственность налоговых агентов, которыми являются российские контрагенты по сделке. Надо обратить внимание на то, что в импортные договоры и контракты запрещено включать налоговые оговорки, в соответствии с которыми российская сторона или наоборот, нерезидент берет на себя обязательства нести расходы по уплате налогов за других плательщиков.

Таким образом, задачей аудитора является проверка полноты исполнения российскими предприятиями функций налогового агента для избежания применения к нему штрафных санкций.

Аудит импорта работ и услуг целесообразно проводить методом сплошной документальной проверки.

\section{5. Типичные ошибки, выявленные аудиторами в процессе аудита внешнеэкономической деятельности хозяйствующих субъектов}

Для повышения качества проверки, сокращения сроков и трудозатрат аудиторской организации целесообразно вести (составлять) постоянно пополняемый перечень ошибок, допускаемых предприятием, которые, по мнению аудитора, существенным образом влияют на финансовую отчетность.

На основании классификации ошибок, предусмотренной внутренним стандартом, могут быть предусмотрены критерии перехода от одного вида аудиторского заключения к другому, а также определен уровень 
существенности, который влечет отражение таких нарушений непосредственно в аналитической (второй) части аудиторского заключения с подробным изложением их в качестве аудиторских доказательств в информации, подготавливаемой для исполнительного органа проверяемой организации.

Ошибки, которые допускает предприятие могут быть классифицированы на исправимые и неисправимые. Причиной исправимых ошибок является нарушение методологии бухгалтерского учета. Существуют также ошибки, которые приводят к нарушению валютного законодательства. Их причиной являются несвоевременное, неправильное составление первичных документов, неверная их классификация при отражении на счетах бухгалтерского учета, т.е. записи в регистрах бухгалтерского учета сделаны на основании первичных документов, которые не отвечают требованиям ст.9 Федерального закона от 21.11.96 г. № 129-Ф3 "О бухгалтерском учете".

К типичным ошибкам, выявляемым при аудите экспортно-импортных операций относятся:

- В типовых формах применяемых организациями импортных и экспортных контрактов часто отсутствует непосредственное указание на дату перехода права собственности. При выборе проверки тех или иных договорных взаимоотношений с контрагентами аудиторы, как правило, руководствуются степенью риска, которая может содержаться в данных договорах, опираясь на свой опыт в подобных проверках и разборе аналогичных ситуаций.

- Несформированный подход к организации документооборота приводит к тому, что документы, на основании которых бухгалтер должен оперативно и правильно дать оценку оприходованным импортным материальным ценностям, поступают с опозданием, часто уже после того, как товар прошел таможенную границу и был реализован российскому покупателю.

- Неправильное формирование учетной стоимости товара, что приводит к искажению расчета налога на прибыль, курсовых разниц, формирующих внереализационные доходы и расходы, а также оценку остатка товара в бухгалтерском балансе. 
- Неправильная рублевая оценка в зависимости от курса может занижать либо завышать налог на прибыль.

- Отсутствие на ГТД печати таможенных органов «товар вывезен полностью», а НДС в декларации указан к возмещению.

- Неправильное отражение хозяйственных операций на счетах бухгалтерского и налогового учета.

- $\quad$ Экспортный товар не оплачен, но в декларации по НДС указан в разделе 5 к возмещению.

Типичными нарушениями при проверке расходов по загранкомандировкам являются следующие:

- покупка юридическим лицом товара за рубежом без заключения контракта;

- $\quad$ расчеты наличной иностранной валютой за приобретаемые за границей товары, так как такие операции относятся к капитальным и на них необходимо разрешение Банка России;

- товар при ввозе на территорию Российской Федерации не декларируется юридическим лицом, что является нарушением таможенного режима;

- $\quad$ при ввозе товара на таможне не оплачиваются таможенные платежи (таможенные пошлины, сборы, НДС), что является нарушением налогового законодательства и т.д.

\section{Контрольные вопросы}

1. Аудит системных вопросов (аудит документов) при аудите внешнеэкономической деятельности.

2. Аудит учетной политики экономического субъекта, осуществляющего внешнеэкономическую деятельность.

3. Аудит отчетности экономического субъекта, осуществляющего внешнеэкономическую деятельность. 
4. Пообъекный и циклический подходы к аудиту отчетности экономического субъекта, осуществляющего внешнеэкономическую деятельность.

5. Действия аудитора при выявлении нарушений законодательства по отчетности при аудите внешнеэкономической деятельности.

6. Методика аудиторской проверки кассовых операций при осуществлении внешнеэкономической деятельности.

7. Методика аудиторской проверки банковских операций при осуществлении внешнеэкономической деятельности.

8. Методика аудиторской проверки валютных операций при осуществлении внешнеэкономической деятельности.

9. Методика аудиторской проверки расчетов с покупателями и заказчиками экспортной продукции.

10. Методика аудиторской проверки с разными дебиторами и кредиторами при внешнеэкономической деятельности.

11. Аудит расчетов с бюджетом при проведении аудита внешнеэкономической деятельности.

12. Методика аудиторской проверки формирования финансовых результатов от внешнеэкономической деятельности.

13. Аудит финансового состояния экономических субъектов, осуществляющих внешнеэкономическую деятельность.

14. Методика аудиторской проверки имущества и обязательств, выраженных в иностранной валюте.

15. Методика аудиторской проверки затрат на производство экспортируемой продукции.

16. Методика аудиторской проверки выпуска готовой продукции на экспорт.

17. Методика аудиторской проверки реализации готовой продукции на экспорт.

18. Типичные ошибки, выявленные аудиторами в процессе аудита внешнеэкономической деятельности. 


\section{Примеры решения задач}

\section{Задача 1}

Составьте общий плана аудита основных средств и нематериальных активов ОАО «ИНТЕРПРОДУКТ».

\section{Решение}

\section{Общий план аудита основных средств и нематериальных активов}

Проверяемая организация

Период учета

Количество человекочасов

Руководитель аудиторской группы

Состав аудиторской группы

Планируемый аудиторский риск

Планируемый уровень существенности
ОАО «ИНТЕРПРОДУКТ

С 01.01.2009 по 31.12.2009

280

Иванов И.И.

Иванов И.И., Петров П.П.

$4 \%$

$1 \%$

\begin{tabular}{|c|c|c|c|c|}
\hline $\begin{array}{l}\text { № } \\
\text { П/II }\end{array}$ & Планируемые виды работ & $\begin{array}{l}\text { Период } \\
\text { проведения }\end{array}$ & Исполнитель & Примечания \\
\hline 1. & $\begin{array}{l}\text { Аудит наличия и сохранности основных } \\
\text { средств }\end{array}$ & 02.02 .10 & $\begin{array}{l}\text { Иванов И.И., } \\
\text { Петров П.П. }\end{array}$ & \multirow{7}{*}{$\begin{array}{c}\text { Согласно } \\
\text { сводному } \\
\text { общему } \\
\text { плану аудита } \\
\text { экономическ } \\
\text { ого субъекта }\end{array}$} \\
\hline 2. & Аудит движения основных средств & 03.02 .10 & Иванов И.И. & \\
\hline 3. & Аудит правильности начисления износа & 04.02 .10 . & Петров П.П. & \\
\hline 4. & $\begin{array}{l}\text { Проверка операций учета поступления и } \\
\text { создания нематериальных активов }\end{array}$ & $\begin{array}{l}05.02 .10 \\
06.02 .10\end{array}$ & Иванов И.И. & \\
\hline 5. & $\begin{array}{lcc}\text { Проверка } & \text { учета } & \text { амортизации } \\
\text { нематериальных активов } & \\
\end{array}$ & 07.02 .10 . & Петров П.П. & \\
\hline 6. & $\begin{array}{l}\text { Проверка учета выбытия нематериальных } \\
\text { активов }\end{array}$ & 08.02 .10 . & Иванов И.И. & \\
\hline 7. & $\begin{array}{l}\text { Проверка правильности налогообложения по } \\
\text { основным средствам и } \\
\text { активам }\end{array}$ & 09.02 .10 & $\begin{array}{l}\text { Иванов И.И., } \\
\text { Петров П.П. }\end{array}$ & \\
\hline \multicolumn{4}{|c|}{$\begin{array}{l}\text { Руководитель аудиторской организации } \\
\text { Руководитель аудиторской группы }\end{array}$} & $\begin{array}{l}\text { Сидоров С.С. } \\
\text { Иванов И.И. }\end{array}$ \\
\hline
\end{tabular}

\section{Задачи для самостоятельного решения}

\section{Задача 1}

На текущий валютный счет 06.02. отчетного года было зачислено 1000 долл. США на 30000 руб. В бухгалтерском учете сделана запись Д 52 К 83.

Аналогичная запись произведена 24.02. отчетного года на зачисление 700 долл. США на 21000 руб.

К выпискам банка из валютного счета никакие документы, 
подтверждающие эти операции, не приложены.

Сделать выводы аудитора при анализе данной ситуации.

\section{Задача 2}

Организацией в апреле продана валюта (400 долл. США). Данная операция отражена в учете следующими записями:

Д 57 К 52 - 11200 руб. - списана реализованная валюта с текущего счета (на 21.04 курс долл. США - 28 руб.);

Д 51 К 57 - 11400 руб. - зачислена на расчетный счет рублевая выручка за реализованную валюту (на 23.04. курс долл. США-28,5руб.)

Д 44 К 51 - 265 руб. - списаны комиссионные услуги банка за реализацию валютных средств;

Д 57 К 91-1 - 200 руб. - отражен результат от продажи валюты;

Д 91-1 К 99 - 200 руб. - отражена прибыль от продажи валюты.

Определить каковы результаты проверки данной ситуации на соответствие нормативным актам?

\section{Задача 3}

Организацией было продано оборудование в Польшу. Согласно контракту оборудование реализовано за 40000 долл. США. Покупатель рассчитался двумя платежами:

1. 15.08 - 35000 долл. США на 980000 руб. по курсу 28 руб.

2. 06.09. - 5000 долл. США на 140500 руб. по курсу 28,1 руб.

Отгрузка оборудования по акту приема-передачи произведена 10.09. отчетного года, курс доллара составил - 28,3 руб.

В бухгалтерском учете продажа основных средств за валюту отражена следующим образом:

Д 91-2 К 01 - 850000 руб. - списано оборудование по остаточной стоимости;

Д 02 К 01 - 848000 руб. - списана начисленная амортизация оборудования;

Д 62 К 91-1 - 1120000 руб. - произведена отгрузка оборудования; 
Д 62 К 68 - 186704 руб. - начислен НДС.

Сделать выводы аудитора при анализе данной ситуации.

\section{Задача 4}

Аудитором установлено:

02.01 отчетного года на текущий валютный счет с транзитного счета зачислено 10000 долл. США на сумму 300000 руб., документы, подтверждающие эту операцию, к выписке банка не приложены. Зачисление валютных средств на транзитный валютный счет отражено записью:

\section{Д 52 К 98.}

Аналогичная запись произведена 15.01 отчетного года на зачисление 400 долл. США на сумму 12000 руб.

Определить каковы результаты проверки данной ситуации на соответствие нормативным актам?

\section{Задача 5}

Доли в уставном капитале общества с ограниченной ответственностью распределены следующим образом:

$\checkmark$ иностранный инвестор (немецкое предприятие) $-40 \%$;

$\checkmark$ иностранный инвестор (английское предприятие) $-26 \%$;

$\checkmark$ Российский учредитель (малое предприятие) - 34\%.

Численность работников общества соответствует уровню малого предприятия.

Определить, является ли данная организация субъектом малого предпринимательства и будет ли на него распространяться льготное налогообложение?

Каковы выводы аудитора при анализе данной ситуации?

\section{Задача 6}

Открытое акционерное общество «Вихрь» является одним из двух учредителей предприятия с иностранными инвестициями. Свою долю в уставный капитал ОАО «Вихрь» внесло путем передачи права пользования 
частью здания на 5 лет в сумме 300000 руб. Оба предприятия имеют статус юридического лица. На основании учредительных документов в учете ОАО «Вихрь» сделана запись:

Д 58 К 98 - 300000 руб. - произведен вклад в уставный капитал предприятия.

Определить, каковы будут выводы аудитора при анализе данной ситуации?

\section{Задача 7}

В протоколе общего собрания 000 «Импульс» отражено решение участников об уменьшении уставного капитала до минимального размера, предусмотренного законодательством для 000 «Импульс», путем выкупа долей участников. 000 «Импульс» является предприятием с иностранными инвестициями. Доли участников распределены следующим образом:

$\checkmark$ иностранный инвестор (немецкое предприятие) $-35 \%$;

$\checkmark$ иностранный инвестор (английское предприятие) $-20 \%$;

$\checkmark$ Российский учредитель (малое предприятие) - 14\%;

$\checkmark$ Российский учредитель (физическое лицо) - 31\%.

Уставный капитал (оплаченный) составлял 500000 руб. Было выкуплено долей номинальной стоимостью 100000 руб. по цене 120000 руб. Другие документы, кроме протокола общего собрания участников и платежных поручений, не представлены. В учетных регистрах общества сделаны записи:

Д 81 К 51 - 120000 руб. - выкуплена доля участников;

Д 80 К 81 - 120000 руб. - уменьшен уставный капитал.

Определить, каковы будут выводы аудитора при анализе данной ситуации?

\section{Задача 8}

В сентябре отчетного года учредителям, в том числе иностранным были начислены дивиденды и выданы в форме материалов. Данные материалы по представленным документам не являлись собственностью предприятия. По итогам деятельности за прошлый год и в текущем году предприятием был 
получен убыток. В учете были сделаны записи:

Д 84 К 75-2 - 8000 руб. - начислены дивиденды акционерам - не работникам предприятия;

Д 75-2 К 10-8 000 руб.- выданы материалы в счет оплаты дивидендов;

Д 84 К 70 - 10000 руб. - начислены дивиденды акционерам работникам предприятия;

Д 70 К 10 - 10000 руб. - выданы материалы в счет оплаты дивидендов работникам предприятия.

Определить, каковы будут выводы аудитора при анализе данной ситуации?

\section{Задача 9}

Организацией было продано оборудование в Польшу. Согласно контракту оборудование реализовано за 40000 долл. США. Покупатель рассчитался двумя платежами:

1. 15.08 - 35000 долл. США на 980000 руб. по курсу 28 руб.

2. 06.09. - 5000 долл. США на 140500 руб. по курсу 28,1 руб.

Отгрузка оборудования по акту приема-передачи произведена 10.09. отчетного года, курс доллара составил - 28,3 руб.

В бухгалтерском учете продажа основных средств за валюту отражена следующим образом:

Д 91-2 К 01 - 850000 руб. - списано оборудование по остаточной стоимости;

Д 02 К 01 - 848000 руб. - списана начисленная амортизация оборудования;

Д 62 К 91-1 - 1120000 руб. - произведена отгрузка оборудования;

Д 62 К 68 - 186704 руб. - начислен НДС.

Сделать выводы аудитора при анализе данной ситуации.

\section{Задача 10}

Организация, не являющаяся учреждением науки, выполняет работы, связанные с ремонтом и профилактикой научно-исследовательского 
оборудования, поставленного несколько лет назад в Канаду. Одновременно в рамках данного контракта выполнялись опытно-конструкторские работы по изготовлению дополнительного модуля (опытного образца), который также планировали поставить в место нахождения оборудования в качестве экспортируемого товара с применением налоговой ставки $0 \%$. Поскольку технологические особенности модуля позволяют иностранному заказчику использовать его на территории России, решено было отказаться от его вывоза за рубеж. Каков порядок обложения НДС выполненных нами работ и может ли в рамках одного контракта возникнуть объект налогообложения по двум и более разным основаниям?

\section{Задача 11}

Российской организацией заключен лицензионный договор на право использования товарных знаков с иностранной (не состоящей на учете в качестве налогоплательщика в налоговых органах Российской Федерации) организацией - лицензиаром. Согласно данному договору лицензиар предоставляет сублицензию на использование своих товарных знаков на территории Российской Федерации без передачи права собственности на данные товарные знаки, а российская организация ежемесячно выплачивает лицензионные платежи (роялти). Обязана ли российская организация в качестве налогового агента исчислять и уплачивать в бюджет НДС?

\section{Контрольные тесты}

1. Для обеспечения сохранности аудиторского заключения от внесения несанкционированных изменений аудиторское заключение по результатам проверки внешнеэкономической деятельности готовится следующим образом:

а) аудиторское заключение и приложенная к нему финансовая отчетность брошюруются в единый пакет, листы пронумеровываются, прошнуровываются, опечатываются печатью аудитора с указанием общего количества листов в пакете; 
б) каждая страница аудиторского заключения и приложенной к нему финансовой отчетности подписывается (парафируется) лицом, проводившим аудит (руководителем аудиторской проверки);

в) каждая страница аудиторского заключения и приложенной к нему финансовой отчетности подписывается (парафируется) лицом, проводившим аудит (руководителем аудиторской проверки), либо аудиторское заключение и приложенная к нему финансовая отчетность брошюруются в единый пакет, листы пронумеровываются, прошнуровываются, опечатываются печатью аудитора с указанием общего количества листов в пакете;

г) сдается в архив.

2. Аудитор при аудите внешнеэкономической деятельности оценивает как более надежные аудиторские доказательства:

а) полученные от аудируемого лица;

б) полученные от третьих лиц;

в) собранные непосредственно аудитором;

г) смешанные.

3. Если аудитор по результатам проверки организаций, занимающихся внешнеэкономической деятельностью, высказал в заключении безоговорочно положительное мнение, означает ли это, что в непрерывности деятельности предприятия нет сомнений:
а) вопрос решается аудитором;
б) нет, не означает;
в) да, означает;
г) вопрос решается аудируемым лицом. 


\section{Глава 7. Особенности аудита прочих операций по ВЭД}

\section{1. Аудит сделок встречной торговли}

Предметом отдельной проверки должны быть все сделки, по которым или совсем не производятся денежные расчеты, или они ограничены. Очень часто такие сделки организации классифицируют как бартерные. Однако при этом в группу бартерных сделок включаются и такие, которые с точки зрения их правовой основы таковыми не являются [23].

Осуществляя аудиторскую проверку всех сделок, по которым организация не производит денежные расчеты, аудитор должен руководствоваться Указом Президента Российской Федерации от 18.08.96 г. № 1209 «О государственном регулировании внешнеторговых бартерных сделок».

Формы встречной торговли различны. Сделки при встречной торговле можно разделить на несколько видов: встречные закупки; бартерные; компенсационные.

Аудитору следует иметь в виду, что удовлетворение претензии может осуществляться дополнительными поставками или путем уменьшения поставок другой стороной. Однако допускаются расчеты по претензиям и в денежной форме. Это не противоречит требованию Указа № 1209 о том, что при осуществлении бартерных сделок не могут использоваться денежные или иные платежные средства: данное требование относится к расчетам за товары, работы, услуги, результаты интеллектуальной деятельности, являющиеся предметом договора, а удовлетворение претензий не является предметом сделки.

Аудитор должен убедится, что при определении налога на прибыль договорная стоимость встречного товара, полученных услуг и результатов выполненных работ является выручкой от реализации поставленного в порядке обмена товара, выполненных работ, предоставленных услуг, а расходы, связанные с получением этой выручки, представляют собой себестоимость 
реализованных товаров, работ, услуг.

В зависимости от момента перехода права собственности на обмениваемые товары могут возникать также внереализационные доходы и расходы в виде положительных или отрицательных курсовых разниц. Они возникают при временном разрыве между датой перехода права собственности на вывозимый товар и датой получения в собственность встречного товара, предоставления встречных услуг, выполнения встречных работ. Датой выполнения работ, предоставления услуг считается дата акта сдачи-приемки, подписанного обеими сторонами.

При ввозе встречного товара на таможенную территорию Российской Федерации взимаются пошлины, сборы и налог на добавленную стоимость. Таможенные пошлины и сборы исчисляются от таможенной стоимости импортного товара, а сумма НДС - от таможенной стоимости, увеличенной на сумму таможенной пошлины. При этом таможенная стоимость определяется в соответствии с порядком, установленным для ее определения при ввозе товаров, импортируемых по договору купли-продажи.

Бухгалтерский учет отражает движение двух встречных потоков товаров, работ, услуг.

В бартерной сделке каждая сторона выступает одновременно в роли и продавца, и покупателя. Поэтому бухгалтерский учет операций по передаче сторонами договора друг другу обмениваемых товаров представляет собой отражение в учете российской организации движения двух товарных потоков экспортируемых и импортируемых товаров. Каждый из них должен быть своевременно поставлен на учет, поэтому в бартерном договоре, как и в любом договоре купли-продажи, должен быть определен момент перехода права собственности к покупателям. Если же это условие не предусмотрено договором и иное не установлено законом, то в соответствии с ГК РФ право собственности на обмениваемые товары приобретается сторонами одновременно с того момента, когда они обе выполнят свои обязательства по передаче товаров. 
Обязательства каждого продавца заключаются в поставке товара покупателю. В свою очередь по обязательствам, предусматривающим перевозку, товар считается поставленным, если он передан перевозчику для передачи его покупателю.

В зависимости от того, как определяется момент перехода права собственности и в какой последовательности осуществляется исполнение сторонами своих обязательств по договору, строятся схемы бухгалтерского учета. Если право собственности переходит к сторонам бартерной сделки неодновременно в тот момент, когда они обе исполнят свои обязательства по поставке, в учете возникают курсовые разницы.

\section{2. Аудит посреднических операций}

Высокий аудиторский риск связан с проверкой посреднических операций. При отражении в учете операций, связанных с оказанием посреднических услуг, допускаются существенные искажения бухгалтерского учета, приводящие к недостоверности бухгалтерской отчетности. Так, при учете операций по договору комиссии с иностранной фирмой на реализацию товаров в Российской Федерации все расходы российской стороны должны относиться за счет иностранной фирмы, поэтому их следует списывать в дебет счета 76, субсчет «Расходы, возмещаемые за счет комитента». На практике их часто списывают как собственные расходы на продажу в дебет счета 44. При этом договорную стоимость товаров, проданных российским покупателям, отражают в учете как выручку от продажи. Ошибка заключается в том, что к комиссионеру не переходит право собственности на товар, следовательно, и выручка от его продажи не может отражаться у него в учете.

Если функции российского посредника заключаются в том, чтобы купить товар в одной стране и продать его в другую, то должен быть оформлен договор комиссии с одной из иностранных фирм на оказание ей услуг соответственно на продажу или покупку товара. В этом случае выручкой 
российского посредника является сумма комиссионного вознаграждения, которая может устанавливаться и в виде разницы цен покупки и продажи.

При отсутствии договора на оказание посреднических услуг сделка должна оформляться двумя контрактами - один на импорт товара, другой на экспорт. В этом случае выручкой является не разница в цене товара, а его экспортная стоимость. Цена закупленного, т.е. импортного, товара представляет собой расходы экспортера. И хотя по сумме вознаграждение равно разнице в цене, тем не менее она должна выявляться на счете «Продажи» развернуто, без уменьшения кредитового оборота по счету, что связано с оборотными налогами. Такие сделки получили название реэкспортных.

Проводя аудит посреднических операций, аудитор анализирует договоры комиссии, заключенные российскими экспортерами и импортерами с российскими посредниками. При этом отношения сторон по договору комиссии должны строиться в соответствии с ГК РФ.

\section{3. Аудит соответствия внешнеэкономических операций правовому, валютному и таможенному законодательству}

Аудит соответствия внешнеэкономических операций правовому, валютному и таможенному законодательству является одним из элементов комплексной методики проведения аудиторской проверки внешнеэкономической деятельности организаций, направленной на повышение качества аудита и способствующей формированию профессионального суждения аудитора о достоверности бухгалтерской отчетности и финансовой устойчивости экономического субъекта.

Законодательство Российской Федерации в целом включает в том числе и гражданское законодательство, содержащее нормы хозяйственного права.

Правовое, валютное и таможенное регулирование внешнеэкономических операций является неотъемлемой частью законодательства Российской Федерации. Поэтому соответствие указанных операций этим видам законодательства также должно входить в задачи аудиторских проверок. 
Кроме того, положением по бухгалтерскому учету «Бухгалтерская отчетность организаций» (ПБУ 4/99), утвержденным приказом Минфина России от 6.07.99 г. № 43н, одно из требований, предъявляемых к отчетности, заключается в том, что бухгалтерская отчетность должна давать достоверное и полное представление о финансовом положении организации, финансовых результатах ее деятельности и изменениях в ее финансовом положении. При этом критерием достоверности и полноты бухгалтерской отчетности согласно указанному Положению является не только формирование ее показателей исходя из правил, установленных нормативными актами по бухгалтерскому учету. Если при составлении бухгалтерской отчетности организацией выявляется, что данных для формирования полного представления о финансовом положении организации, финансовых результатах ее деятельности и изменениях в ее финансовом положении недостаточно, то в бухгалтерскую отчетность организация должна включить соответствующие дополнительные показатели и пояснения. Отступление от этих правил допускается только в исключительных случаях.

Очевидно, что отложенные во времени последствия финансовых санкций за нарушение правового, валютного и таможенного законодательства изменят финансовое положение организации и даже могут привести к прекращению деятельности данного экономического субъекта. Даже если не умышленно, а вследствие недостаточной квалификации бухгалтерских и финансовых работников или из-за отсутствия у них специальных знаний в области международного, гражданского права, валютного, таможенного законодательства возможность наступления финансовых санкций не будет указана в пояснениях к отчетности, то такая отчетность не может считаться достоверной.

Следовательно, аудитор, не проверяющий внешнеэкономические операции на их соответствие правовому, валютному, таможенному законодательству и подтверждающий при этом достоверность финансовой отчетности, несет повышенный аудиторский риск при формировании суждения 
о возможности применения к проверяемому экономическому субъекту допущения непрерывности деятельности.

Вряд ли можно считать обоснованной и такую точку зрения некоторых аудиторов, что при наличии таможенно-банковского контроля отпадает необходимость в проверке внешнеэкономических операций на их соответствие валютному и таможенному законодательству. Во-первых, эта позиция основана на постулате доверия, а аудитор никогда не должен исключать сговор. Вовторых, не все внешнеэкономические операции либо не все их аспекты попадают в сферу банковского контроля. В-третьих, валютный контроль не настолько совершенен, чтобы можно было исключить ошибки.

Таким образом, аудитор должен выявить операции, осуществленные экономическим субъектом с нарушением валютного и таможенного законодательства, и при выдаче аудиторского заключения учесть вероятность того, что последующее применение санкций за эти нарушения окажет существенное влияние на финансовое положение организации и может поставить под сомнение возможность ее функционирования в обозримой перспективе.

Для проведения аудита внешнеэкономических операций на их соответствие правовому, валютному и таможенному законодательству требуется соответствующая информационная база. В принципе, она не ограничена и значительно шире, чем для внутренних операций организации, за счет зарубежных источников. Однако для получения аудиторских доказательств по этому направлению проверки из всех внутренних и внешних источников информации можно выбрать следующие, наиболее важные, отражающие ключевые этапы любой внешнеэкономической сделки с учетом ее экономических и юридических аспектов.

Основным документом, в котором содержатся все сведения о заключенной сделке, является внешнеторговый контракт. На стадии его заключения решаются вопросы правового регулирования отношений сторон внешнеэкономической сделки и ее условия. На стадии исполнения контракта 
несоблюдение правовых норм, допущенное при его заключении, может привести и к финансовым последствиям.

Для аудитора будет полезной информация о том, что к методам государственного регулирования внешнеторговой деятельности относятся также запрет и ограничения внешней торговли услугами и интеллектуальной собственностью.

Правильное определение категории внешнеэкономического договора имеет для аудитора практическое значение: если договор не признается международным, к отношениям сторон по такому договору применяются нормы российского гражданского законодательства. В зависимости от категории договора к нему применяются и разные нормы валютного законодательства.

Экспертиза внешнеторговых контрактов состоит в проверке на соответствие условий контракта требованиям к их содержанию.

Аудитору следует проанализировать все случаи расторжения контрактов и причины их аннулирования. Если контракт аннулируется при нарушении условий, которые не могут быть признаны существенными, нельзя исключить, что при его заключении не ставилась цель исполнения контрактных обязательств. В этом случае требуется тщательная проверка движения денежных средств по контракту.

При исполнении внешнеторговых контрактов в отличие от внутренних договоров купли-продажи происходит перемещение товаров через государственную границу стран, коммерческие организации которых являются сторонами контракта.

В практике нашей страны уплата пошлин является необходимым условием перемещения товаров через таможенную границу как при их вывозе, так и при ввозе. Кроме того, при ввозе товаров на таможенную территорию Российской Федерации в зависимости от таможенного режима взимаются налог на добавленную стоимость, а также акцизы по подакцизным товарам. В связи с этим существенное значение имеет методика определения таможенной 
стоимости (таможенной оценки) товара, являющейся исходной базой для начисления адвалорных пошлин, таможенных сборов и НДС. При этом она поразному определяется для экспортируемых и импортируемых товаров.

Нормативно-правовой основой для определения таможенной стоимости экспортируемых товаров являются Закон Российской Федерации от 21.05.93 г. № 5003-1 (с изменениями на 23.12.03 г.) «О таможенном тарифе» и постановление Правительства Российской Федерации от 7.12.96 г. № 1461 «О Порядке определения таможенной стоимости товаров, вывозимых с таможенной территории Российской Федерации».

Таможенная стоимость определяется декларантами, но контролируется таможенными органами. Знание аудитором принципов ее определения позволяет ему контролировать правильность исчисления базы для расчета таможенных платежей и выявлять несоответствие величины таможенной стоимости и ее структуры тем документам, которые предъявлены в ее подтверждение.

Аудиторский контроль за обоснованностью выбора метода оценки таможенной стоимости необходим для того, чтобы убедиться в отсутствии сговора между таможней и аудируемым экономическим субъектом. Однако крайне сложно оценить объективность источника, подтверждающего величину надбавок и вычетов при корректировке цены. Поэтому при отсутствии у аудитора специальных знаний в области таможенного производства ему следует привлекать эксперта по этим вопросам с тем, чтобы использовать его оценку в качестве аудиторских доказательств.

Закон «О валютном регулировании и валютном контроле», нормативные документы Банка России, принятые им в рамках этого Закона по отдельным направлениям валютного регулирования, по конкретным вопросам, формируют законодательную базу в сфере регулирования валютных операций. Она составляет неотъемлемую часть информационной базы аудита внешнеэкономической деятельности организаций на предмет соответствия внешнеэкономических операций нормам валютного законодательства. 
Проверку внешнеэкономических операций на их соответствие валютному регулированию можно рассматривать в качестве аналитической процедуры для получения аудиторских доказательств. Результаты данной аналитической процедуры могут свидетельствовать о степени вероятности искажений бухгалтерского учета и бухгалтерской отчетности, обусловленных нарушением валютного законодательства.

\section{4. Аудит оказания услуг по договорам между резидентами и нерезидентами}

Основная задача аудита услуг связана с проверкой исполнения российской организацией функций налогового агента и обоснованности неудержания им налогов с нерезидента.

Согласно российскому законодательству в определенных случаях у нерезидента, получающего доход от источников в Российской Федерации, возникают налоговые обязательства по уплате налога на доход и налога на добавленную стоимость. Будет ли он сам платить налоги или их должен удержать у нерезидента налоговый агент - российское юридическое лицо, являющееся источником выплаты дохода, зависит прежде всего от статуса иностранного юридического лица.

В соответствии с НК РФ в том случае, если иностранное юридическое лицо имеет статус постоянного представительства, оно должно состоять на учете и платить налоги самостоятельно. При этом понятие постоянного представительства является чисто налоговым, и критерий наличия постоянного представительства у иностранной фирмы - это регулярное осуществление деятельности на территории Российской Федерации. Следовательно, аудитор должен убедиться в том, стоит ли на учете в налоговом органе иностранное юридическое лицо. От этого зависит, должна ли проверяемая им российская организация исполнить функцию налогового агента при выплате иностранной фирме дохода. Косвенно это подтверждается наличием идентификационного 
номера налогоплательщика на расчетно-платежных документах. Но этого недостаточно. У российской организации - партнера по сделке должна быть копия свидетельства о постановке нерезидента на учет в налоговых органах, нотариально заверенная и оформленная не ранее чем в предшествующем налоговом периоде. При отсутствии документального подтверждения о постановке нерезидента на налоговый учет российская организация должна удержать налог.

Другим фактором, определяющим возникновение у российской организации обязательств по исполнению функций налогового агента, является место оказания услуг. Если российская организация получили услуги от нерезидента на территории иностранного государства, то они не являются объектом налогообложения (в отличие от услуг оказанных). Однако факт получения услуг за рубежом должен быть подтвержден документально.

Основанием для удержания налоговым агентом НДС с доходов иностранного юридического лица является признание местом реализации работ, услуг территории Российской Федерации. Но критерии для признания территории Российской Федерации местом реализации работ и услуг согласно НК РФ применяются разные в зависимости от характера работ и услуг. В соответствии со ст. 148 «Место реализации работ (услуг)» НК РФ все работы и услуги разделены на пять групп:

1. Услуги, связанные с недвижимым имуществом.

2. Услуги, связанные с движимым имуществом.

3. Услуги в сфере образования, культуры, искусства, физкультуры, туризма, отдыха и спорта.

4. Услуги, перечисленные в п. 4 ст. 148 НК РФ. В этот закрытый перечень входят различные консультационные услуги (но не все), рекламные услуги; передача в собственность или переуступка патентов, лицензий, торговых марок, авторских прав и др.; обработка информации при проведении НИОКР; услуги по обслуживанию воздушных судов в аэропортах и воздушном пространстве, по обслуживанию морских судов и судов внутреннего плавания в 
период стоянки в портах и при лоцманской проводке и др.

5. Все остальные услуги, не вошедшие в перечисленные группы.

Приведенными в ст. 148 НК РФ перечнями и критериями должен руководствоваться аудитор, определяя обоснованность удержания или неудержания НДС с нерезидента.

По первой группе работ и услуг местом реализации признается та территория, где находится недвижимость, по второй и третьей группам - место фактического выполнения работ, оказания услуг.

Аудитор должен убедиться в том, что место выполнения работ, оказания услуг подтверждается контрактами, другими документами.

Особо следует проверить услуги по перевозке экспортных и импортных грузов на предмет обоснованности применения налоговой ставки 0 процентов. Эта ставка применяется в отношении услуг по транспортировке, погрузке и перегрузке, а также сопровождению экспортируемых за пределы территории Российской Федерации и импортируемых в Российскую Федерацию товаров в том случае, если перевозчиком является российская организация.

Аудитору нужно обратить внимание на следующие моменты, связанные с удержанием НДС. Сумма налога исчисляется от полной суммы платежа, если в контракте он не указан и не выделен отдельной строкой в расчетных документах. В бюджет сумма налога перечисляется одновременно с перечислением платежа иностранному партнеру по сделке. Предъявить к вычету уплаченную за нерезидента сумму налога налоговый агент может только в том случае, если полученные от нерезидента услуги (работы) используются в производственной деятельности.

Следует отметить, что услуги (работы) настолько разнообразны по своему характеру, настолько специфичны, что каждая услуга, каждый вид работ требуют при проверке индивидуального подхода. Поэтому при проведении аудита услуг выборочный метод проверки не эффективен.

К недостоверности отчетной информации по внешнеэкономическим операциям приводит не только искажение учетных данных, но и нарушение 
правового, валютного и таможенного законодательства. Поэтому проверка таких операций на соответствие этим видам законодательства должна включаться в программу аудита.

Объектом повышенного внимания аудитора должны быть внешнеэкономические сделки, заключаемые в нетрадиционных для российской практики формах: такие формы заключения сделок недостаточно отрегулированы в правовом законодательстве Российской Федерации, что приводит к искажению данных бухгалтерского учета и соответственно бухгалтерской отчетности.

При планировании аудита внешнеэкономических сделок большое внимание должно быть уделено анализу разделов внешнеторговых контрактов, имеющих непосредственное отношение к бухгалтерскому учету и влияющих на финансовые результаты деятельности экономического субъекта (условия расчетов, санкции и др.).

В задачу аудита внешнеэкономических сделок, которая должна найти отражение в программе аудиторской проверки, входит экспертиза контрактов на соответствие требованиям к их оформлению и содержанию, а также нормам международного права и законодательства Российской Федерации, так как при наличии таких противоречий сделка может быть признана недействительной.

Контроль за соблюдением правового, валютного и таможенного законодательства на стадии проведения внешнеэкономических операций должен стать необходимым элементом внутреннего аудита, что требует от работников, занимающихся внешнеэкономической деятельностью, глубокого знания законодательной базы валютных операций.

Организация аудита экономических субъектов, занимающихся в том числе и внешнеэкономической деятельностью, должна строиться с учетом необходимости проведения аудиторской проверки внешнеэкономических операций в качестве самостоятельного объекта аудита. 


\section{Контрольные вопросы}

1. Экспертиза хозяйственных договоров по внешнеэкономической деятельности на соответствие законодательству.

2. Методика аудиторской проверки расчетов с покупателями и заказчиками экспортной продукции.

3. Аудит порядка отражения в бухгалтерском учете расчетов по авансам, полученным в счет предстоящих поставок товаров на экспорт.

4. Методика аудиторской проверки импортных материальных ценностей.

5. Методика аудиторской проверки расчетов с поставщиками и подрядчиками импортной продукции.

6. Особенности аудита импортных нематериальных ценностей (работ, услуг).

7. Оценка соответствия импортных операций таможенному законодательству.

8. Использование в аудите импортных операций результатов банковского валютного контроля.

\section{Примеры решения задач}

\section{Задача 1}

Проведите проверку внешнеторгового контракта условного предприятия.

\section{Решение}

Проверяемая организация

Период учета

Количество человекочасов

Руководитель аудиторской группы

Состав аудиторской группы

Планируемый аудиторский риск

Планируемый уровень существенности
ОАО «ИНТЕРПРОДУКТ»

С 01.01.2009 по 31.12.2009

280

Иванов И.И.

Иванов И.И., Петров П.П.

$4 \%$

$1 \%$

\section{Проверка оформления внешнеторговых контрактов}

\begin{tabular}{|c|l|l|c|}
\hline $\begin{array}{c}\text { № } \\
\text { п/п }\end{array}$ & \multicolumn{1}{|c|}{ Проверяемые реквизиты } & \multicolumn{1}{|c|}{ Значение } & Замечание \\
\hline \multicolumn{2}{|c|}{ Общие сведения о контракте } \\
\hline 1 & Унифицированный номер & $643 / 78312019 / 003$ & Соответствует \\
\hline 2 & Дата подписания & $20.11 .2008 г$. & Соответствует \\
\hline 3 & Место подписания Мответствует \\
\hline 4 & $\begin{array}{l}\text { Официальное } \\
\text { контрагента, страна }\end{array}$ & Иран, г.Малаир & Соответствует \\
\hline 5 & $\begin{array}{l}\text { Адреса, реквизиты, банковские } \\
\text { счета, подписи, печати }\end{array}$ & $\begin{array}{l}\text { Компания Голден Драйд Фруйтс 555 } \\
\text { Малаир, г.Малаир Иран }\end{array}$ & Соответствует \\
\hline
\end{tabular}




\begin{tabular}{|c|c|c|c|}
\hline \multicolumn{4}{|c|}{ Предмет договора } \\
\hline 6 & $\begin{array}{l}\text { Наименование и характеристики } \\
\text { товара }\end{array}$ & $\begin{array}{l}\text { В соответствии со спецификацией- } \\
\text { приложением }\end{array}$ & Соответствует \\
\hline 7 & Момент перехода прав & FОВ-Иранский порт(ИНКОТЕРМС) & Соответствует \\
\hline 8 & Порядок и сроки поставки & Партиями до 31.12.2008г. & Соответствует \\
\hline 9 & Качество товара & По образцам & Соответствует \\
\hline 10 & Упаковка/маркировка & $\begin{array}{l}\text { Обеспечивающая } \\
\text { сохранность/подробная }\end{array}$ & Соответствует \\
\hline 11 & Общая сумма & 950000 долларов США & Соответствует \\
\hline 12 & Цена товара & $\begin{array}{l}\text { В соответствии со спецификацией- } \\
\text { приложением }\end{array}$ & Соответствует \\
\hline 13 & $\begin{array}{l}\text { Приложения } \\
\text { партию }\end{array}$ & Счета продавца & Соответствует \\
\hline \multicolumn{4}{|c|}{ Условия платежа } \\
\hline 14 & Порядок платежа & $\begin{array}{l}\text { Банковским переводом, частично } \\
\text { встречными поставками }\end{array}$ & Соответствует \\
\hline 15 & Срок платежа & $\begin{array}{l}\text { В течение } 90 \text { календарных дней с } \\
\text { даты поставки }\end{array}$ & Соответствует \\
\hline 16 & Штрафные санкции & $\begin{array}{l}\text { 0,5\%от суммы неоплаченного товара } \\
\text { за каждый день просрочки }\end{array}$ & Соответствует \\
\hline \multicolumn{4}{|c|}{ Условия поставки } \\
\hline 17 & Условия поставки & FOВ-Иранский порт (ИНКОТЕРМС) & Соответствует \\
\hline 18 & Место доставки & г.Астрахань & Соответствует \\
\hline 19 & Извещение на отгрузку & Заказ & Соответствует \\
\hline 20 & Штрафные санкции & $\begin{array}{l}\text { За несоответствие качества штраф } \\
0,5 \% \text { от стоимости товара }\end{array}$ & Соответствует \\
\hline \multicolumn{4}{|c|}{ Документация } \\
\hline 21 & $\begin{array}{l}\text { Товаросопроводительные } \\
\text { документы }\end{array}$ & 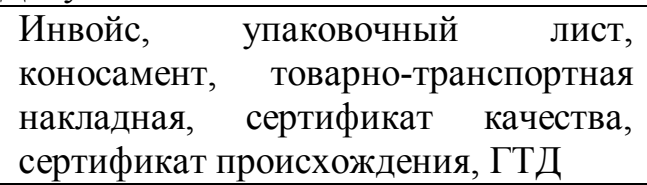 & Соответствует \\
\hline 22 & Гарантия на товар & Отсутствует & Соответствует \\
\hline 23 & Арбитраж и применимое право & Российское, ТПП & Соответствует \\
\hline 24 & Форс-мажор & Освобождение от ответственности & Соответствует \\
\hline
\end{tabular}

\section{Задачи для самостоятельного решения}

\section{Задача 1}

В ходе аудиторской проверки было установлено, что в первом квартале отчетного года $3 \mathrm{AO}$ «Экономъ» оплатило расходы по обучению бухгалтера и программиста фирмы в размере 20500 руб. на курсах повышения квалификации. Аудитору были предоставлены следующие документы :

- договоры с государственными учебными заведениями;

- квитанции к приходным ордерам соответствующих учебных заведений на сумму 8400 руб.; 
- платежное поручение на сумму 9600 руб. .

В бухгалтерском учете указанные суммы были отражены следующими проводками:

Д 26 К $51-15000$ руб.

Д 19 К 51 - 3000 руб.

Д 68 К 19 - 3000 руб.

Официальная справка : Фонд оплаты труда в первом квартале отчетного года составил 515580 руб.

Укажите ошибки, выявленные в ходе аудита, и пути их устранения.

\section{Задача 2}

В ходе обязательной аудиторской проверки было установлено следующее: 20 октября по чеку, выписанному на предъявителя и подписанного руководителем и главным бухгалтером, было получено из отделения банка на хозяйственные нужды 10000 руб. . В представленных на проверку документах имеется авансовый отчет коммерческого директора на сумму 10000 руб., в котором указано, что полученные деньги были израсходованы на командировку. К авансовому отчету приложено командировочное удостоверение, подтверждающее участие коммерческого директора в оптовой ярмарке в другом городе и железнодорожный билет до этого города в одну сторону. Других замечаний и нарушений выявлено не было.

Примите обоснованное решение о выдаче аудиторского заключения.

\section{Задача 3}

В ходе обязательной аудиторской проверки при аудите расчетов с персоналом по оплате труда было установлено, что с сотрудника Иванова О.С. ежемесячно, начиная с марта отчетного года по декабрь включительно (10 месяцев), удерживалась сумма в размере 1000 руб. . Основанием для удержания явилось личное заявление сотрудника от 17 февраля отчетного года с просьбой предоставить беспроцентную ссуду на 10 месяцев в размере 10000 руб. В бухгалтерском учете были оформлены следующие проводки :

Д 76 К 50 - 10000 руб. (выдана ссуда); 
Д 70 К 76 - 1000 руб. (ежемесячные удержания).

Официальная справка : Согласно даннымм штатного расписания заработная плата Иванова О.С. в отчетном периоде составляла 1200 руб. .

Укажите нарушения, допущенные бухгалтерией и пути их устранения.

\section{Задача 4}

В ходе инициативной аудиторской проверки было установлено, что на протяжении первых трех лет своей деятельности ООО «Фаэтон» испытывало серьезные финансовые затруднения. Заработная плата сотрудникам выдавалась нерегулярно, а иногда даже не начислялась. В ряде случаев основные средства и материалы покупались на личные средства руководства с последующей компенсацией. Однако, в мае отчетного года после удачно совершенной коммерческой сделки был получен доход, значительно превысивший предполагаемый. Руководство решило премировать сотрудников за успехи в бизнесе, начислив каждому дополнительно к зарплате за май по 30000 руб. . Общая сумма премиального фонда в размере 210000 руб. была отнесена на затраты. С указанной суммы был удержан подоходный налог, сделаны все необходимые начисления и удержания в государственные внебюджетные фонды.

Определите нарушения, допущенные ООО «Фаэтон», и возможность возникновения налоговых рисков. Предложите варианты устранения выявленных ошибок.

\section{Задача 6}

В ходе проведения аудиторской проверки было установлено, что решением суда в организации с 1 сентября отчетного года восстановлен в должности менеджера штатный сотрудник. По этому же решению организация выплатила сотруднику заработную плату за время вынужденного прогула в размере 16000 руб. и 5000 руб. в счет компенсации морального ущерба, а также 5000 руб. в счет возмещения судебных издержек. Все выплаты были включены в годовой совокупный доход сотрудника с последующим удержанием налога на доходы физических лиц. На сумму заработной платы и 
компенсации были также начислены платежи во внебюджетные фонды. Источники погашения произведенных затрат: себестоимость на сумму заработной платы и прибыль на сумму компенсации морального ущерба и на сумму возмещения судебных издержек.

Определите нарушения, допущенные бухгалтером при оформлении соответствующих операций. Примите обоснованное решение о выдаче аудиторского заключения. Напишите аналитическую часть аудиторского заключения при условии, что во всех иных существенных аспектах бухгалтерская отчетность достоверна.

\section{Контрольные тесты}

1. Аудиторская организация обязана при аудите финансовой отчетности получить более детальную информацию о деятельности экономического субъекта, для того чтобы:

а) общаться с персоналом аудируемого лица;

б) адекватно интерпритировать смысл информации;

в) проводить обучение бухгалтерского персонала аудируемого лица;

г) провести инвентаризацию.

2. Для оценки неотъемлемого риска на уровне финансовой отчетности аудитор учитывает:

a) счета бухгалтерского учета, которые могут быть подвержены искажениям;

б) факторы, влияющие на отрасль, к которой относится аудируемое лицо;

в) подверженность активов потерям или незаконному присвоению.

г) рассчитывает условно.

3. Взаимосвязь между размером выборки и величиной ошибки, которую аудитор считает допустимой (существенной):

a) обратная (чем ниже величина допустимой ошибки, тем больше необходимый размер выборки);

в) прямая (чем выше величина допустимой ошибки, тем больше необходимый размер выборки); 

в) отсутствует;
г) смешанная.

4. При аудите финансовой отчетности основная аудиторская организация использует работу другой аудиторской организации, если:

а) другая аудиторская организация проводит аудит финансовой отчетности подразделения, показатели которого включаются в отчетность основной организации;

б) аудиторская организация проводила аудит финансовой отчетности за предыдущий год;

в) для аудита финансовой отчетности привлекался индивидуальный аудитор;

г) не использует.

5. Модифицированное аудиторское заключение с факторами, влияющими на мнение аудитора, содержит отдельную часть, которая:

а) располагается после части, содержащей мнение аудитора;

б) предшествует части, содержащей мнение аудитора;

в) располагается по усмотрению аудитора;

г) такого нет.

6. Задачей аудитора на этапе наблюдения является:

a) проверка достоверности и существенности признаков банкротства, заявленных руководителями организации;

б) контроль над соразмерным удовлетворением требований кредиторов;

в) проверка и оценка реальности и эффективности последней попытки спасти организацию от финансового краха;

г) оценить объем работ. 


\section{Заключение}

В заключении хотелось бы отметить, что сегодня экономика в России все еще находится в процессе реформирования. При этом одной из главных задач является повышение качества управления организацией, в том числе и через приближение российских стандартов бухгалтерского учета и отчетности к международным стандартам финансовой отчетности, а также посредством усиления роли аудита и внутреннего контроля во внешнеэкономической деятельности.

Анализируя существующие формы контроля за внешнеэкономичекой деятельностью, мы смогли выделить как сходства их целей, задач и методов, так и различия.

Сегодня все большее значение приобретает для организаций квалифицированная помощь со стороны аудиторских фирм, как в отношении ведения бухгалтерского учета, подтверждения достоверности бухгалтерской (финансовой) отчетности, так и в отношении анализа финансово-хозяйственной деятельности организаций, налогового и управленческого консультирования.

Однако, стоит отметить, что организации, воспользовавшись такой помощью, не всегда могут достичь конкурентного преимущества, так как пока что, к сожалению, предлагаемые аудиторами решения, являются типовыми для организаций или не соответствуют специфики какого - то отдельно взятой организации.

Анализ отечественных и международных стандартов и методик проведения аудита внешнеэкономической деятельности позволил нам сделать вывод, что сегодня рынок аудиторских услуг в России развит недостаточно, особенно в сфере нормативного регулирования аудита и имеет ряд серьезных ограничений.

Таким образом, с целью совершенствования организации и проведения аудита необходимо принять ряд мер по совершенствованию, как законодательства, регулирующую внешнеэкономическую деятельность, так и нормативных актов аудита, разработав такие правила (стандарты) аудиторской 
деятельности, которые смогли бы способствовать более качественному проведению аудита, учитывая специфические черты отрасли. При этом их приближение к международным стандартам аудита также расширит возможности аудиторов в сфере аудита и повысит качество оказываемых ими услуг. 


\section{СПИСОК РЕКОМЕНДУЕМОЙ ЛИТЕРАТУРЫ \\ НОРМАТИВНЫЕ АКТЫ}

1. Федеральный закон «Об аудиторской деятельности» № 307-Ф3 от 30.12.2008 г.

2. Правила (стандарты) аудиторской деятельности. М.: «Бухгалтерский учет», 2000 г.

3. Федеральные правила (стандарты) аудиторской деятельности.

4. План счетов бухгалтерского учета и Инструкция по его применению (Приказ Минфина РФ №94-н от 31 ноября 2000г.).

5. Положение по бухгалтерскому учету «Расходы организации» (ПБУ 9/99).

6. Положение по бухгалтерскому учету «Расходы организации» (ПБУ 10/99).

7. Положение по бухгалтерскому учету «Учет материальнопроизводственных запасов» (ПБУ 5/01).

8. Положение по бухгалтерскому учету «Учетная политика организации » (ПБУ 1/98).

9. Аудит в России. Законодательство. М.: «Инвест Фонд», 2009 г.

\section{СПИСОК РЕКОМЕНДУЕМОЙ ЛИТЕРАТУРЫ}

\section{ОСНОВНАЯ ЛИТЕРАТУРА}

10.Аудит: Учебник для вузов/В.И. Подольский, Г.Б. Поляк, А.А. Савин, Л.В. Сотникова, Под ред. Проф. В.И. Подольского.- М.: Изд-во ЮНИТИДАНА, 2009г.

11.Барышников Н.П. Организация и методика проведения общего аудита. М.: ИНФРА - М, 2004. - 249 с.

12.Барыленко В.И. Учет, анализ и аудит внешнеэкономической деятельности. - М.:ИНФРА - М, 2009. - 458 с.

13.Безруких П.С., Власенко Л. И. И др. Бухгалтерско - аудиторский портфель. М.: «Соминтекс», 2000. - 306 с. 
14.Белуха Н. Т. Судебно - бухгалтерская экспертиза. М.: «Дело ЛТД», 2005. $-206 \mathrm{c}$.

15.Глушков И. Е. Аудит на современном предприятии. - Москва Новосибирск: «КНОРУС - ЭКОР», 2004 г.

16. Куликов Г.В. Аудит экспортных операций. - М.: ЮНИТИ-ДАНА, 2003. - $157 \mathrm{c}$.

17.Кулинина Г.В., Юшкова С.Д. Аудит импортных операций. - М.: ЮНИТИ-ДАНА, 2004. - 190 с.

18.Лупикова Е.В., Пашук Н.К. Учет и аудит внешнеэкономической деятельности: учебное пособие. - М.: КНОРУС, 2009. - 256 с.

19.Овсийчук М.Ф., Камышанов П.И. Аудит. Организация. Методика проведения. - М.: «ИНТЕЛТЕКС», 2000. - 241 с.

20.Патров В.В, Быков В. А. Аудит внешнеэкономической деятельности/ В. В. Патров, В. А. Быков// Бухгалтерский учёт. - 2007.

21.Подольский В. И. Аудит. Учебник, М.: ЮНИТИ, 2001. - 583 с.

22.Подольский В.И., Савин А.А. Аудит: Учебник для вузов. М.: ЮНИТИ, 2005. - 301 с.

23.Шалашова Н.Т. Аудит внешнеэкономических операций. - М.: Финансовая газета, 2004. - 48 с.

\section{ДОПОЛНИТЕЛЬНАЯ ЛИТЕРАТУРА}

24.Альборов Р.А. «Аудит в организациях промышленности, торговли и АПК». - М.: Дело и сервис, 2004. - 381 с.

25.Ремизов Н.А. Аудит. Учебное пособие: - М.: ИД ФБК - ПРЕСС, 2001. $-175 \mathrm{c}$.

26.Смирнов Н. Б. Основы российского аудита. - М.: ДИС, 2000. - 167 с.

27.Стуков С. А. Введение в аудит. - М.: Тарвер, 2004. - 100 с.

28.Терехов А.А.,Терехов М.А. Контроль и аудит: основные методологические приемы и технология. - М.: Финансы и статистика, 2001. $-261 \mathrm{c}$. 
29.Шеремет А.Д. Аудит: Учебное пособие. - М.: ИНФРА - М, 2000. - 217 с.

30.Шишкин А.К., Микруков В.А., Дышкант И.Д. Учет, анализ, аудит на предприятии. - М.: Аудит, ЮНИТИ, 2000. - 386 с.

31.Журнал «Аудиторские ведомости», 2003 - 2009 г.г.

32.Журнал «Бухгалтерский учет», 2003 - 2009 г.г. 


\title{
Приложения
}

Приложение 1

\section{РЕКОМЕНДАЦИИ ПО МИНИМАЛЬНЫМ ТРЕБОВАНИЯМ К ОБЯЗАТЕЛЬНЫМ РЕКВИЗИТАМ И ФОРМЕ ВНЕШНЕТОРГОВЫХ КОНТРАКТОВ (УТВ. МВЭС РФ ОТ 29.02.1996)}

\author{
"Утверждаю" \\ Заместитель министра \\ внешних экономических связей \\ Российской Федерации \\ М.А. Сарафанов \\ "_29__"_февраля \\ 1996 г.
}

РЕКОМЕНДАЦИИ

ПО МИНИМАЛЬНЫМ ТРЕБОВАНИЯМ К ОБЯЗАТЕЛЬНЫМ РЕКВИЗИТАМ

И ФОРМЕ ВНЕШНЕТОРГОВЫХ КОНТРАКТОВ

\begin{abstract}
Во внешнеторговом контракте целесообразно указывать:
унифицированный номер контракта, состоящий из трех групп знаков с двумя разделителями /, сформированных следуюшим образом:
\end{abstract}

ББ/XXXXXXXX/XXXXX или ЦЦЦ/XXXXXXXX/XXXXX,

где

первая группа состоит из двух букв (ББ) или трех цифр (цЦц), соответствующих коду страны Покупателя (Продавца) по международному классификатору "Страны мира", используемым для целей таможенного оформления;

вторая группа состоит из восьми цифр, составляющих код организации

Покупателя (Продавца) в соответствии с общероссийским классификатором "Предприятия и организации" (ОКПо) ;

третья группа состоит из пяти цифр и представляет собой порядковый номер документа на уровне организации Покупателя (Продавца) .

дата подписания контракта, оформляемая следующим образом:

ДД. ММ . ГГ .

где

ДД - день (2 цифры);

MМ - месяц (2 цифры) ;

ГГ - год (2 последние цифры года) .

Каждые две цифры отделяются друг от друга точкой;

место подписания контракта;

полные официальные наименования организаций Продавца и Покупателя ;

страна иностранного партнера и страна назначения (отправления) товара.

Приводится полное наименование стран и их трехзначный код в соответствии с международным классификатором "Страны мира", используемым для целей таможенного оформления. 
УКАЗЫВАЮТСЯ :

Наименование и полная характеристика товара.

Полное коммерческое наименование товара, ассортимент, размеры, модели, комплектность, страна происхождения товара и другие данные, необходимые для описания товара, включая ссылки на международные и/или национальные стандарты на продукцию.

тара/упаковка, маркировка товара.

Наименование тары или упаковки в соответствии с международным классификатором "Коды для видов груза, упаковок и материалов упаковок (с дополнительными кодами для наименований упаковок)". Описание и требования к маркировке товара.

объем, вес, количество товара.

объем груза, его вес с упаковкой (брутто) или без нее (нетто) в согласованных единицах измерения.

В случае необходимости приводится количество товара в единицах измерения в соответствии с таблицей единых измерений, приведенноц в ТН ВЭД.

\section{ЦЕНА И СУММА}

Указывается общая сумма контракта и цена за единицу товара в валюте цены с приведением краткого наименования базиса поставки в соответствии с международными правилами толкования стандартных формулировок условий поставки товара ("ИНКОТЕРМС 2000"). Наименование и код валюты, в которой оценен товар в соответствии с классификатором валют, используемым для целей таможенного оформления .

В случаях, когда цена за единицу товара и сумма контракта не могут быть точно установлены на дату подписания контракта, приводится подробная формула цены либо условия ее определения с таким расчетом, чтобы при реализации всех оговоренных условий можно было однозначно установить цену товара и сумму контракта.

\section{УСЛОВИЯ ПЛАТЕЖА}

Дается описание условий платежа.

Указываются наименование и код валюты, в которой будет производится платеж, в соответствии с классификатором, используемым для целей таможенного оформления, сроки платежа и условия рассрочки, при ее предоставлении, а также обязательный перечень документов, передаваемых Продавцом Покупателю и подтверждающих факт отгрузки, стоимость и номенклатуру отгруженных товаров.

Рекомендуется предусматривать аккредитивную форму платежа или другую форму, гарантирующую безусловное поступление валютной выручки при экспорте товаров, а также предоставление гарантий на возврат платежа, ранее переведенного в оплату импортируемых товаров, в случае их непоступления.

Указываются полные наименования и почтовые адреса банков (филиалов) сторон, номера счетов, платежные реквизиты. 


\title{
СРОК ПОСТАВКИ
}

Приводится порядок поставки товаров, т.е. дата завершения поставок и/или график поставок конкретных партий товара с указанием срока действия контракта, в течение которого должны быть завершены поставки товаров и взаимные расчеты по контракту .

\section{УСЛОВИЯ ПРИЕМКИ ТОВАРА ПО КАЧЕСТВУ И КОЛИЧЕСТВУ}

Указываются место и сроки проведения инспекции качества и количества товара, наименование независимой экспертной организации, порядок предъявления рекламаций.

\author{
ФОРС - МAЖОР \\ Формулируются форс-мажорные обстоятельства .
}

ПРОЧИЕ УСЛОВИЯ И ОБСТОЯТЕЛЬСТВА СДЕЛКИ

В специальных пунктах или разделах контракта оговариваются другие условия и обстоятельства сделки (гарантийные обязательства, лицензионные платежи, техническая помощь, сборка, наладка и монтаж оборудования, обучение персонала, информационные и другие услуги).

\section{РАССМОТРЕНИЕ СПОРОВ}

Приводится порядок предъявления и

рассмотрения неурегулированных претензий, порядок платежей по претензиям, рассмотрение спорных вопросов в Арбитраже. Указывается правом какого государства будут регулироваться отношения по контракту .

\section{САНКЦИИ}

Указываются санкции за ненадлежащее исполнение обязательств сторон, в частности за просрочки в поставке товара и/или просрочки в оплате стоимости товара, а также поставки товара ненадлежащего количества и качества.

\section{АДРЕСА ПОКУПАТЕЛЯ И ПРОДАВЦА}

Юридические и полные почтовые адреса Продавца и Покупателя, контактный телефон, факс, телекс организации (предприятия) Продавца и Покупателя.

\section{ПОДПИСИ СТОРОН}

Даются подписи лиц, уполномоченных организациями Продавца и Покупателя заключить контракт, заверенные печатью, с указанием их Ф.И.О. и должностей.

"Согласовано" Начальник Департамента регулирования ВЭД МВЭС России

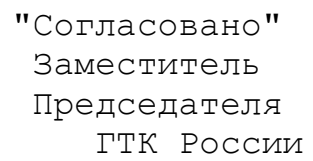

"Согласовано" Заместитель Руководителя ВЭК РОссии 
Приложение 2

\section{ПРИМЕР ПИСЬМА О ПРОВЕДЕНИИ АУДИТА}

Совету директоров или соответствующему представителю высшего руководства организации

Вы обратились к нам с просьбой о проведении обязательного аудита финансовой (бухгалтерской) отчетности в составе (указать состав) за (указать финансовый год). Настоящим письмом мы подтверждаем наше согласие и наше понимание данного задания. Аудит будет проведен нами с целью выражения мнения о достоверности финансовой (бухгалтерской) отчетности и соответствии порядка ведения бухгалтерского учета законодательству Российской Федерации.

Мы будем проводить аудит в соответствии с федеральными правилами (стандартами) аудиторской деятельности. Эти стандарты требуют, чтобы мы планировали и проводили аудит с целью обеспечения разумной уверенности в том, что финансовая (бухгалтерская) отчетность не содержит существенных искажений. Аудит проводится на выборочной основе и включает в себя изучение на основе тестирования доказательств, подтверждающих числовые значения в финансовой (бухгалтерской) отчетности и раскрытие в ней информации о финансово-хозяйственной деятельности. Аудит также включает оценку применяемых принципов и методов бухгалтерского учета, правил подготовки финансовой (бухгалтерской) отчетности, определение основных оценочных значений, сформированных руководством аудируемого лица, а также оценку общей формы представления финансовой (бухгалтерской) отчетности.

В связи с тем, что в ходе аудита применяются выборочные методы и тестирование, и в связи с другими присущими аудиту ограничениями, наряду с ограничениями, присущими любой системе бухгалтерского учета и 
внутреннего контроля, существует неизбежный риск того, что некоторые, даже существенные, искажения могут остаться необнаруженными.

В дополнение к аудиторскому заключению, содержащему наше мнение о достоверности финансовой (бухгалтерской) отчетности, мы планируем предоставить Вам отдельное письмо (отчет, письменную информацию), касающееся любых замеченных нами существенных недостатков в ведении бухгалтерского учета и в системе внутреннего контроля.

Напоминаем, что в соответствии с законодательством Российской Федерации ответственность за подготовку финансовой (бухгалтерской) отчетности, в том числе за раскрытие в ней необходимой информации, несет руководство Вашей организации. Это включает ведение бухгалтерского учета в соответствии с требованиями законодательства Российской Федерации, наличие и надлежащую работу средств внутреннего контроля, выбор и применение учетной политики, а также меры по сохранности и надлежащему использованию активов организации. Нам потребуются от руководства организации (и это является частью процесса аудита) официальные письменные подтверждения, касающиеся наиболее важных разъяснений и заявлений, сделанных в связи с аудитом.

Надеемся на сотрудничество с Вашими сотрудниками и на то, что нам будут предоставлены любые записи, документация и иная информация, запрашиваемая в связи с аудитом. Средства за проведение аудита, выплачиваемые на основе счетов, которые будут выставляться по мере оказания услуги, рассчитываются исходя из времени, затраченного специалистами на выполнение задания, и включают покрытие командировочных расходов. Почасовая оплата варьируется в зависимости от уровня ответственности используемых специалистов, их опыта и квалификации.

Данное письмо считается действительным в будущем до тех пор, пока оно не будет изменено или заменено другим либо его действие не будет прекращено. 
Просим Вас подписать и вернуть прилагаемый экземпляр данного письма в подтверждение того, что оно соответствует Вашему пониманию договоренности о проведении нами аудита финансовой (бухгалтерской) отчетности Вашей организации.

Принимается от имени

От имени аудитора

Фамилия, имя, отчество, должность, дата

(подпись)

$$
\text { хозяйствующего субъекта }
$$

Фамилия, имя, отчество, должность, дата

(подпись) 
Приложение 3

\section{Примерный договор об оказании аудиторских услуг}

$\Gamma$.

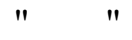
20 $\Gamma$.

(наименование предприятия, оказывающего аудиторские

услуги), именуем в дальнейшем Аудитор, в лице (должность, ф.и.о.), действующего на основании документа), с одной стороны, и (устава, положения, иного предприятия, пользующегося услугами аудитора), именуем (наименование (должность, ф.и.о),

действующего на основании (устава, положения, иного документа), с другой стороны, заключили настоящий договор о нижеследующем.

1. Заказчик поручает, а Аудитор принимает на себя обязательства по даче заключений по финансовым отчетам Заказчика (за квартал, полугодие, год), а также

\section{(перечислить иные виды услуг)}

2. Срок дачи заключений по финансовым отчетам:

Сроки оказания иных видов услуг:

3. Стоимость оказываемых услуг составляет:

4. Расчеты между сторонами производятся в следующем порядке:

\section{5. Заказчик обязуется:}

- предоставлять Аудитору данные по оперативному бухгалтерскому учету, документы, планы, приказы, а также иную необходимую документацию;

- выделять рабочие места для работников Аудитора, шкаф-сейф для хранения документов;

- обеспечить при необходимости присутствие своих материально ответственных лиц, печатание подготовленных Аудитором документов;

- оплачивать оказываемые услуги в соответствии с условиями настоящего договора.

6. Аудитор обязуется:

- соблюдать правила внутреннего распорядка предприятия Заказчика;

- применять при оказании услуг законные и объективные методы и средства, подкреплять выводы документально;

- не разглашать выявленные в ходе работы или сообщенные ему данные, являющиеся информацией конфиденциального характера или составляющие коммерческую тайну.

7. Особые условия по договору:

8. За неисполнение или ненадлежащее исполнении своих обязанностей по настоящему договору стороны несут ответственность, предусмотренную действующим законодательством.

9. Споры между сторонами разрешаются путем переговоров.

10. В случае невозможности разрешения споров мирным путем, они разрешаются в порядке, установленном действующим законодательством.

11. Настоящий договор вступает в силу с момента подписания, составлен в экземплярах.

12. Юридические адреса сторон.

Аудитора:

Заказчика:

Подписи, печати 
Приложение 4 
Приложение 5

\section{Ответы к контрольным тестам}

\begin{tabular}{|c|c|c|c|c|c|c|c|}
\hline \multirow{2}{*}{$\begin{array}{c}\text { № п/п } \\
\text { вопроса }\end{array}$} & \multicolumn{7}{|c|}{ Варианты ответов } \\
\hline & Глава 1 & Глава 2 & Глава 3 & Глава 4 & Глава 5 & Глава 6 & Глава 7 \\
\hline 1. & $6, \mathrm{a}, \Gamma, \mathrm{B}$ & 6 & $\mathrm{a}$ & B & $\Gamma$ & $\mathrm{B}$ & 6 \\
\hline 2. & в, г, a, б, д & $\Gamma$ & 6 & $\mathrm{a}$ & $\mathrm{B}$ & $\mathrm{B}$ & 6 \\
\hline 3. & B & B & - & $\begin{array}{l}a-b \\
\sigma-B \\
B-A\end{array}$ & 6 & B & 6 \\
\hline 4. & $\Gamma$ & $\mathrm{a}$ & - & - & B & - & $\mathrm{a}$ \\
\hline 5. & 6 & B & - & - & $\mathrm{a}$ & - & $\mathrm{a}$ \\
\hline 6. & $\Gamma$ & $\mathrm{a}$ & - & - & - & - & $\Gamma$ \\
\hline 7. & B & д & - & - & - & - & - \\
\hline 8. & $\Gamma$ & $\Gamma$ & - & - & - & - & - \\
\hline 9. & B & $\mathrm{a}$ & - & - & - & - & - \\
\hline 10. & $\mathrm{a}$ & $\Gamma$ & - & - & - & - & - \\
\hline 11. & 6 & $a$ & - & - & - & - & - \\
\hline 12. & $\Gamma$ & $\mathrm{a}$ & - & - & - & - & - \\
\hline 13. & B & 6 & - & - & - & - & - \\
\hline 14. & B & - & - & - & - & - & - \\
\hline 15. & $a$ & - & - & - & - & - & - \\
\hline 16. & 6 & - & - & - & - & - & - \\
\hline 17. & 6 & - & - & - & - & - & - \\
\hline 18. & 6 & - & - & - & - & - & - \\
\hline 19. & $\mathrm{a}$ & - & - & - & - & - & - \\
\hline
\end{tabular}


Приложение 6

Примерный перечень рабочих документов аудитора при проведение аудита организаций, осуществляющих внешнеэкономическую деятельность ${ }^{8}$

1. Информация, касающаяся организационно - правовой формы и организационной структуры организации, осуществляющей внешнеэкономическую деятельность;

2. Выдержки или копии учредительных документов организации, осуществляющей внешнеэкономическую деятельность, а также необходимых юридических документов, соглашений и протоколов;

3. Информация об отрасли, экономической и правовой среде, в которой организация, ведущая внешнеэкономическую деятельность, осуществляет свою деятельность;

4. Информация, отражающая процесс планирования, включая программы аудита и любые изменения к ним;

5. Доказательства понимания аудитором систем бухгалтерского учета и внутреннего контроля (описания, вопросники, схемы документооборота или их комбинации);

6. Доказательства, подтверждающие оценку неотъемлемого риска, уровня риска средств контроля и любые корректировки этих оценок;

7. Доказательства, подтверждающие факт анализа аудитором работы аудируемого лица по внутреннему аудиту и сделанные аудитором выводы;

8. Анализ финансово - хозяйственных операций и остатков по счетам бухгалтерского учета;

9. Анализ наиболее важных экономических показателей и тенденций их изменения;

\footnotetext{
${ }^{8}$ Составлено на основе данных п. 11 Федерального правила (стандарта) аудиторской деятельности № 2 «Документирование аудита»
} 
10.Сведения о характере, временных рамках, объеме аудиторских процедур и результатах их выполнения;

11.Доказательства, подтверждающие, что работа, выполненная работниками аудитора, осуществлялась под контролем квалифицированных специалистов и была проверена;

12.Сведения о том, кто выполнял аудиторские процедуры, с указанием времени их выполнения;

13.Подробная информация о процедурах, примененных в отношении финансовой (бухгалтерской) отчетности организации, осуществляющей внешнеэкономическую деятельность и/или дочерних организаций, проверявшихся другим аудитором;

14.Копии сообщений, направленных другим аудиторам, экспертам и третьим лицам и полученных от них;

15.Копии писем и телеграмм по вопросам аудита, доведенным до сведения руководителей аудируемого лица или обсуждавшимся с ними, включая условия договора о проведении аудита или выявленные существенные недостатки системы внутреннего контроля;

16.Письменные заявления, полученные от аудируемого лица;

17.Выводы, сделанные аудитором по наиболее важным вопросам аудита, включая ошибки и необычные обстоятельства, которые были выявлены аудитором в ходе выполнения процедур аудита, и сведения о действиях, предпринятых в связи с этим аудитором;

18.Копии финансовой (бухгалтерской) отчетности и аудиторского заключения. 
Приложение 4

Типовая схема этапа планирования аудита ВЭД

\begin{tabular}{|c|c|c|}
\hline 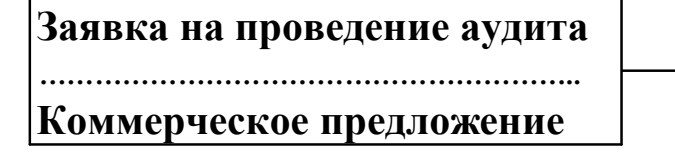 & \multirow{2}{*}{\multicolumn{2}{|c|}{$\begin{array}{l}\text { Преддоговорные соглашения сторон об } \\
\text { основных условиях и ограничениях аудита }\end{array}$}} \\
\hline Подготовительный этап аудита & & \\
\hline \multirow{8}{*}{ Предварительное планирование } & & $\frac{1}{V}$ \\
\hline & & Тонимание бизнеса клиента \\
\hline & $\begin{array}{r}\text { O } \\
\text { пов }\end{array}$ & $\begin{array}{l}\text { Определение обстоятельств, способных } \\
\text { лиять на жизнедеятельность клиента }\end{array}$ \\
\hline & & $\begin{array}{l}\text { Ознакомление с организацией и ведением } \\
\text { хгалтерского учета, предварительная оценка } \\
\text { статочности информации для целей аудита }\end{array}$ \\
\hline & & $\begin{array}{c}\text { Ознакомление с организацией и } \\
\text { рункционированием внутреннего контроля }\end{array}$ \\
\hline & & $\begin{array}{c}\text { Определение вероятности оказания } \\
\text { сопутспвющих услуг }\end{array}$ \\
\hline & & $\begin{array}{l}\text { тределение необходимого состава и квалифика- } \\
\text { ционного уровня специалистов, сроков работы }\end{array}$ \\
\hline & & Оценка возможности проведения аудита \\
\hline
\end{tabular}

\begin{tabular}{|c|c|}
\hline \multicolumn{2}{|c|}{ Принятие решений, постановка дополнительных целей } \\
\hline \multirow[t]{3}{*}{ Согласование с банком } & Организационные вопросы \\
\hline & Сопутствующие услуги \\
\hline & Условия договора \\
\hline \multicolumn{2}{|c|}{ Оформление и подписание договора } \\
\hline \multirow{9}{*}{$\begin{array}{c}\text { Разработка общего } \\
\text { плана }\end{array}$} & Анализ представленной информации \\
\hline & Определение задач и целей аудита \\
\hline & Установление уровня сушественности \\
\hline & Оценка внутреннего контроля \\
\hline & Оценка рисков \\
\hline & Выбор аудиторского подхода \\
\hline & Разработка объема работ и графика проведения аудита \\
\hline & Формирование бюджета проекта \\
\hline & Управление и контроль качества аудита \\
\hline
\end{tabular}

Представление общего плана на рассмотрение и утверждение

\begin{tabular}{|c|c|}
\hline \multicolumn{3}{|c|}{ Разработка вариантов плана (или отдельных разделов плана) } \\
\hline $\begin{array}{c}\text { Разработка } \\
\text { программы аудита }\end{array}$ & Планирование программы тестов средств контроля \\
\cline { 2 - 3 } & Планирование программы аудиторских процедур по существу \\
\hline \multicolumn{2}{|c|}{ Подготовка отчета о планировании } \\
\hline
\end{tabular}


